


\section{Lake-Level Frequency Analysis for the Waubay Lakes Chain, Northeastern South Dakota}

By Colin A. Niehus, Aldo V. Vecchia, and Ryan F. Thompson

Water-Resources Investigations Report 99-4122

Prepared in cooperation with the Federal Emergency Management Agency 


\section{U.S. Department of the Interior \\ Bruce Babbitt, Secretary}

\section{U.S. Geological Survey}

Charles G. Groat, Director

The use of firm, trade, and brand names in this report is for identification purposes only and does not constitute endorsement by the U.S. Geological Survey.

Rapid City, South Dakota: 1999

For additional information write to:

\section{District Chief}

U.S. Geological Survey

1608 Mt. View Road

Rapid City, SD 57702

Copies of this report can be purchased from:

\section{U.S. Geological Survey Information Services}

Box 25286

Denver, CO 80225-0286 


\section{CONTENTS}

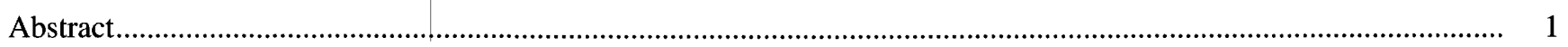

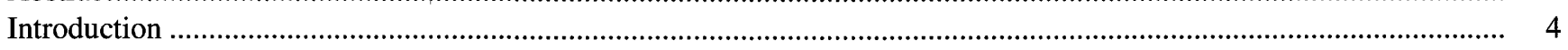

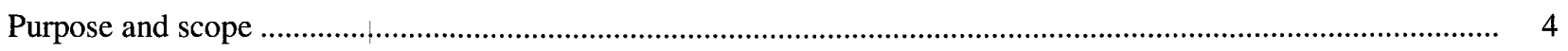

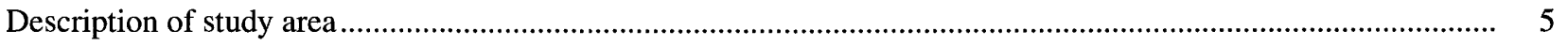

Physiography and climate ................................................................................................................. 5

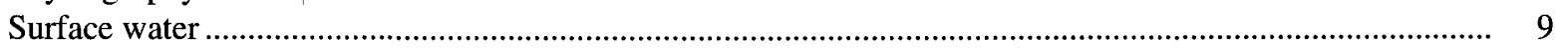

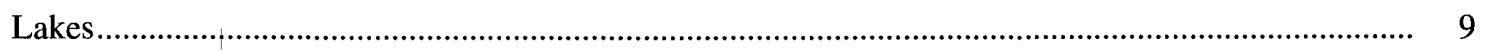

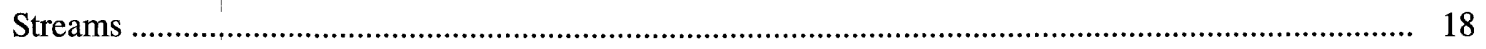

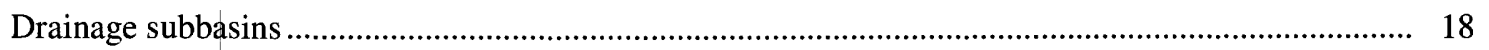

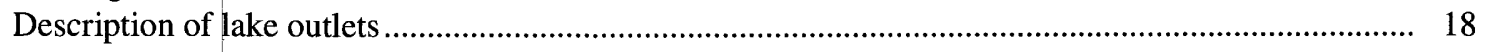

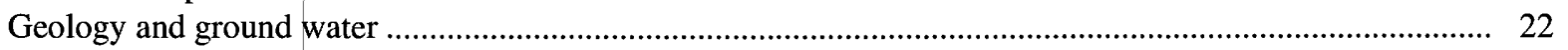

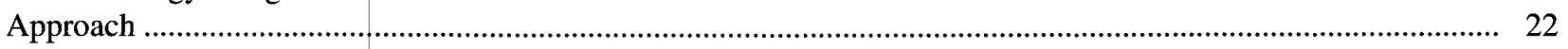

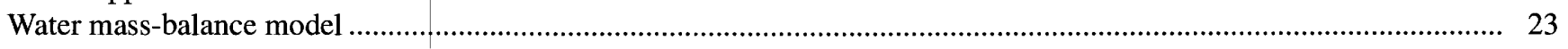

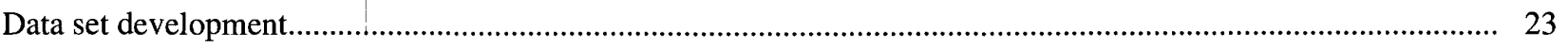

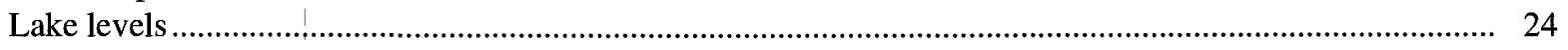

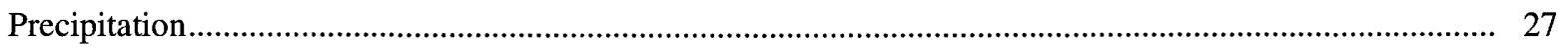

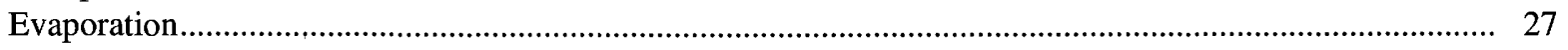

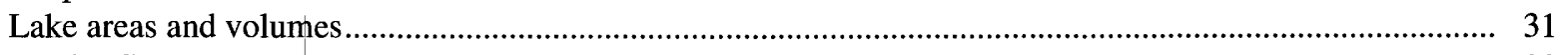

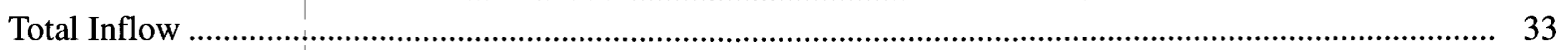

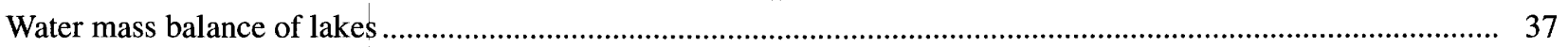

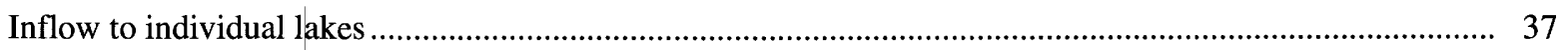

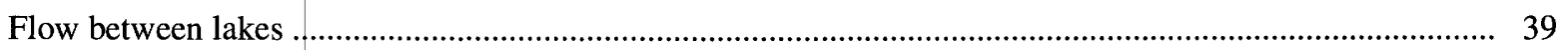

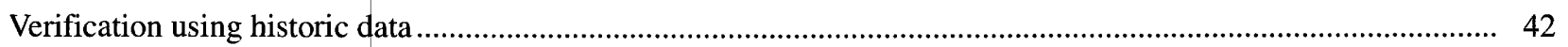

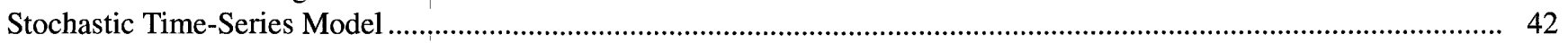

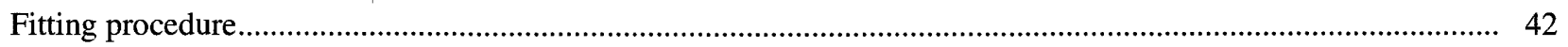

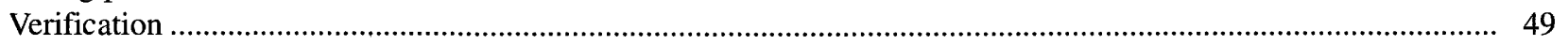

Verification using ancillary linformation on long-term historic lake levels ........................................................ 53

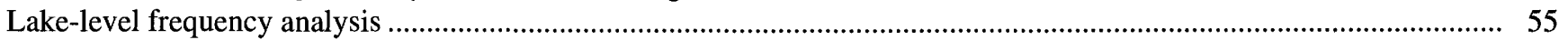

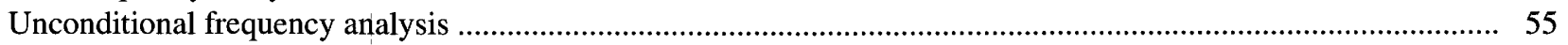

Conditional frequency analysis starting from present conditions ........................................................... 59

Sensitivity of conditional frequency analysis to starting conditions ............................................................... 65

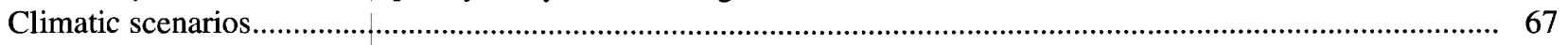

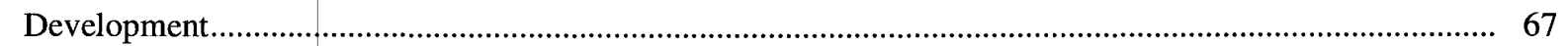

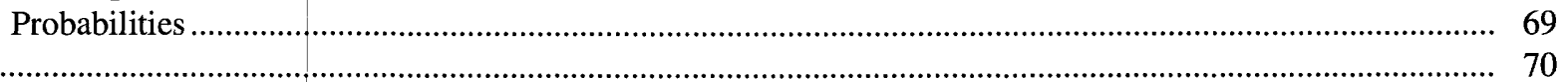

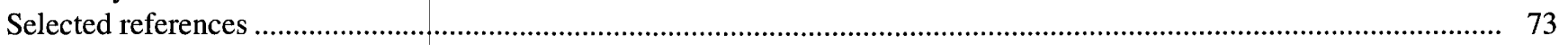

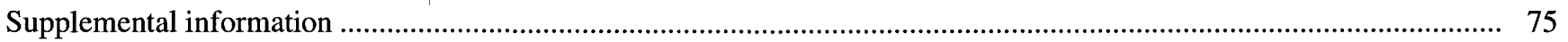

\section{ILLUSTRATIONS}

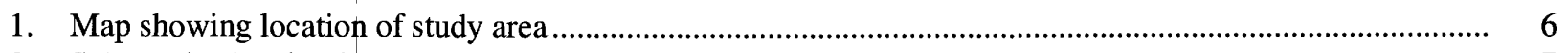

2. Schematic showing lake connections for the Waubay Lakes Chain ......................................................... 7

3. Map showing major physiographic divisions in eastern South Dakota, and location of study area ............... 8

4. Graphs showing historic area of individual lakes within the Waubay Lakes Chain....................................... 14

5. Graphs showing historic volume of individual lakes within the Waubay Lakes Chain ................................ 15

6. Pie charts showing areal distribution of the 10 major lakes of the Waubay Lakes Chain,

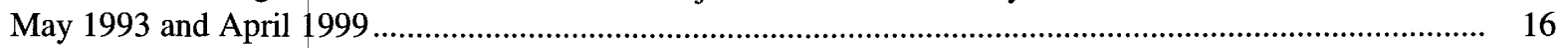




\section{ILLUSTRATIONS-Continued}

7. Pie charts showing volumetric distribution of the 10 major lakes of the Waubay Lakes Chain, May 1993 and April 1999

8. Map showing subbasins for the Waubay Lakes Chain...

9. Map showing water mass-balance model lake and lake-connection numbers for the Waubay Lakes Chain

10. Graphs showing historic lake levels of individual lakes within the Waubay Lakes Chain.

11. Graph showing precipitation versus total inflow for the Waubay Lakes Chain, May-September 1961-98

12. Graphs showing estimated and historic lake levels of individual lakes within the Waubay Lakes Chain, 1960-98

13. Graph showing estimated total lake area for $1960-98$ for the Waubay Lakes Chain

14. Graph showing estimated total lake volume for 1960-98 for the Waubay Lakes Chain

15. Graph showing seasonal precipitation for water years $1961-98$ for the Waubay National Wildlife Refuge Headquarters station

16. Graph showing seasonal estimated evaporation for water years 1961-98 for the Waubay Lakes Chain......... 30

17. Graphs showing lake area curves for individual lakes within the Waubay Lakes Chain............................... 34

18. Graphs showing lake volume curves for individual lakes within the Waubay Lakes Chain .......................... 35

19. Graph showing total inflows for water years $1961-98$ for the Waubay Lakes Chain .................................... 36

20. Graph showing semiannual volume change versus net atmospheric gain for the Waubay Lakes Chain, water years 1961-98

21. Graphs showing simulated and historic lake levels of individual lakes within the Waubay Lakes Chain, 1963-98

22. Graphs showing simulated and historic lake areas of individual lakes within the Waubay Lakes Chain, 1963-98

23. Graphs showing simulated and historic lake volumes of individual lakes within the Waubay Lakes Chain, 1963-98

24. Graphs showing simulated and estimated total area and volume of the Waubay Lakes Chain, 1963-98 ........

25. Graphs showing historic (water years 1963-98) and generated (water years 1999-2120) annual precipitation, evaporation, and total inflow for the Waubay Lakes Chain

26. Graphs showing historic and generated 3-year average annual evaporation versus precipitation, evaporation versus total inflow, and precipitation versus total inflow for the Waubay Lakes Chain

27. Graph showing historic (water years 1963-98) and generated (water years 1999-2880) annual maximum lake levels for Waubay Lake ....

28. Graph showing generated 20-year maximum lake levels for Waubay Lake for simulation 2 using an unconditional frequency analysis.

29. Graph showing historic (water years 1963-98) and generated (water years 1999-2048) annual maximum lake levels for Waubay Lake

30-39. Graphs showing upper and lower probability bounds computed from 10,000 50-year traces from the water mass-balance model, with each trace starting October 1, 1998, for:

30. Bitter Lake

31. Blue Dog Lake.

32. Enemy Swim Lake

33. Hillebrands Lake.

34. Minnewasta Lake

35. Pickerel Lake.

36. Rush Lake...

37. Spring Lake..

38. Swan Pond

39. Waubay Lake

40. Graph showing upper and lower probability bounds for Waubay Lake computed from 10,000

50-year traces from the water mass-balance model, with each trace starting October 1, 1962

41. Graph showing simulated lake levels of Bitter Lake for selected 16-year climatic scenarios, starting with October 1, 1998, lake level 


\section{ILLUSTRATIONS-Continued}

42. Graph showing simulated lake levels of Waubay Lake for selected 16-year climatic scenarios, starting with October 1, 1998, lake level.

43. Graph showing probability bounds and selected 16-year scenario results for Waubay Lake.

\section{TABLES}

1. Annual precipitation and temperature statistics for Webster and Waubay National Wildlife Refuge

National Weather Service stations

2. Characteristics of the 10 major lakes of the Waubay Lakes Chain ............................................................. 10

3. Lake-level, area, and volume changes of the 10 major lakes of the Waubay Lakes Chain, 1993-99 .................. 13

4. Specific conductance data for the 10 major lakes of the Waubay Lakes Chain ................................................... 13

5. Drainage areas of the 10 major lakes of the Waubay Lakes Chain ............................................................... 18

6. Water mass-balance model equations used to compute lake volumes of the 10 major lakes of the Waubay Lakes Chain

7. Fitted parameters for area and volume equations for the 10 major lakes of the Waubay Lakes Chain

8. Water mass-balance model equations used to compute inflow for the 10 major lakes of the Waubay Lakes Chain

9. Water mass-balance model rating equations used to compute flow between the 10 major lakes of the Waubay Lakes Chain

10. Normality transformations for winter and summer precipitation, evaporation, and total inflow.

11. Variable order and potential predictor variables for multivariate, autoregressive time-series model for semiannual precipitation, evaporation, and total inflow

12. Final fitted time-series model for semiannual precipitation, evaporation, and total inflow.

13. Statistics of historic and generated annual precipitation, evaporation, and total inflow data

14. Probability of high lake levels using an unconditional frequency analysis for the Waubay Lakes Chain based on simulation 2 .

15. Probability of low lake levels using an unconditional frequency analysis for the Waubay Lakes Chain based on simulation 2 .

16. Descriptive classification of net lake evaporation and climatic scenario segments for the Waubay Lakes Chain

\section{PLATES}

[Plates are in pocket]

1. Probabilities of lake extents, based on October 1998 beginning lake levels

2. Lake extents in year 2014 for two climatic scenarios and for the 1-percent exceedance probability 


\section{CONTENTS OF SUPPLEMENTAL INFORMATION SECTION:}

A. Photographs of selected features of the Waubay Lakes Chain...................................................................................

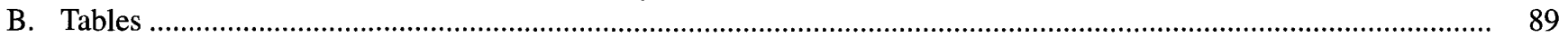

B1. Historic lake levels for the 10 major lakes of the Waubay Lakes Chain .............................................. 91

B2. Semiannual estimated lake levels used in water mass-balance model for the 10 major lakes of the Waubay Lakes Chain ........................................................................................ 113

B3. Precipitation data, in inches, used in water mass-balance model for the Waubay Lakes Chain................ 116

B4. Evaporation data, in inches, used in water mass-balance model for the Waubay Lakes Chain.................. 117

B5. Areas and volumes for the 10 major lakes of the Waubay Lakes Chain.............................................. 118

B6. Total inflow for water years 1961-98 for the Waubay Lakes Chain ..................................................... 124

B7. Simulated lake levels for the 10 major lakes of the Waubay Lakes Chain, 1963-98.............................. 125

B8. Simulated lake areas, in acres, for the 10 major lakes of the Waubay Lakes Chain, 1963-98 ................. 127

B9. Simulated lake volumes, in acre-feet, for the 10 major lakes of the Waubay Lakes Chain, 1963-98

B10. Probability of Waubay Lake exceeding selected lake levels in each of the next 50 years, using October 1, 1998, starting lake levels.

B11. Probability of Waubay Lake exceeding selected lake levels in each of the next 50 years, using October 1, 1962, starting lake levels

C. Explanation of procedures for operating the water mass-balance and stochastic time-series models ........................ 135

C1. Regression procedure for estimating missing lake levels ............................................................ 137

C2. Estimating unknown coefficients in the water mass-balance model equations ....................................... 138

C3. Computing individual lake volumes in the water mass-balance model................................................. 140

C4. Operating the water mass-balance and stochastic time-series models for the Waubay Lakes Chain

D1. Graphs showing estimated and historic lake areas of individual lakes within the

Waubay Lakes Chain, 1960-98

D2. Graphs showing estimated and historic lake volumes of individual lakes within the

Waubay Lakes Chain, 1960-98

D3-D10. Maps showing bathymetric data for:

D3. Bitter Lake.

D4. Blue Dog Lake .................................................................................................. 152

D5. Enemy Swim Lake .................................................................................................. 153

D6. Hillebrands Lake, Spring Lake, and Swan Pond....................................................................... 154

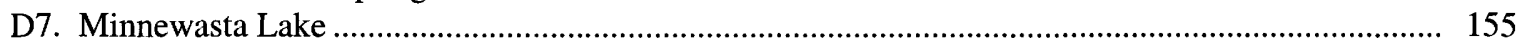

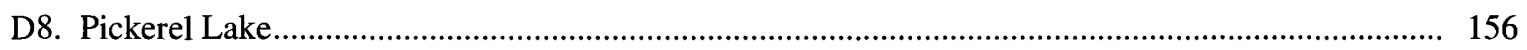

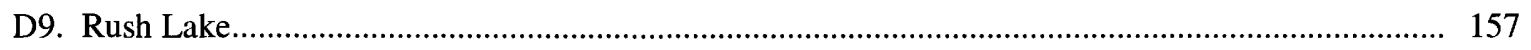

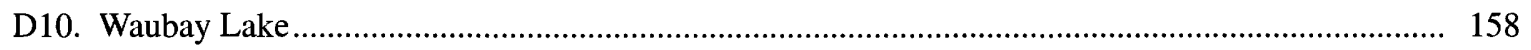

D11-D18. Maps showing additional bathymetric data for:

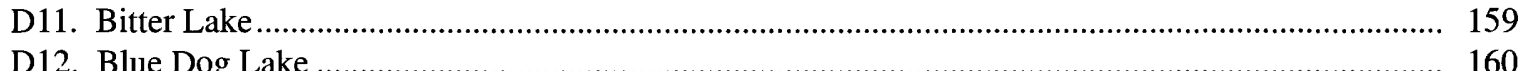

D13. Enemy Swim Lake .................................................................................................... 161

D14. Hillebrands Lake, Spring Lake, and Swan Pond................................................................... 162

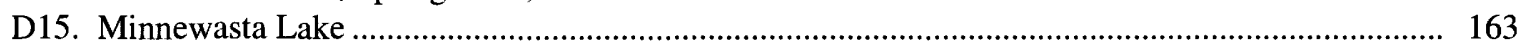

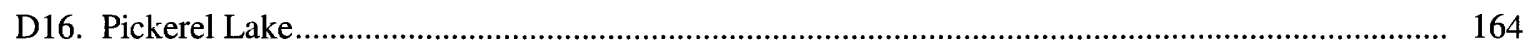

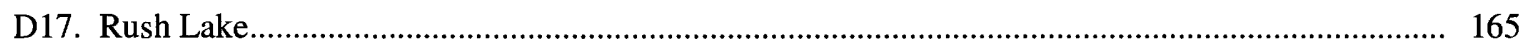

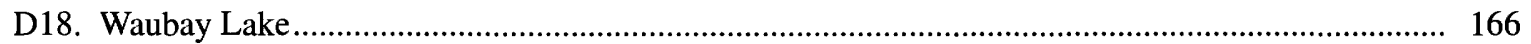




\begin{tabular}{|c|c|c|}
\hline Multiply & By & To obtain \\
\hline \multicolumn{3}{|c|}{ Length } \\
\hline $\begin{array}{r}\text { acre } \\
\text { acre } \\
\text { square mile }\left(\mathrm{mi}^{2}\right) \\
\text { square mile }\left(\mathrm{mi}^{2}\right)\end{array}$ & $\begin{array}{c}4.047 \\
0.4047 \\
259.0 \\
2.590\end{array}$ & $\begin{array}{l}\text { square meter } \\
\text { hectare } \\
\text { hectare } \\
\text { square kilometer }\end{array}$ \\
\hline $\begin{array}{r}\text { cubic foot }\left(\mathrm{ft}^{3}\right) \\
\text { cubic foot }\left(\mathrm{ft}^{3}\right) \\
\text { acre-foot (acre- } \mathrm{ft}) \\
\text { inch per year (in/yr) }\end{array}$ & $\begin{array}{c}28.32 \\
0.02832 \\
1,233 \\
25.4\end{array}$ & $\begin{array}{l}\text { cubic decimeter } \\
\text { cubic meter } \\
\text { cubic meter } \\
\text { millimeter per year }\end{array}$ \\
\hline \multicolumn{3}{|c|}{ Flow rate } \\
\hline $\begin{array}{l}\text { cubic foot per second }\left(\mathrm{ft}^{3} / \mathrm{s} \text { ) }\right. \\
\text { acre-foot per year (acre-ft/yr) } \\
\text { acre-foot per year (acre-ft/yr) }\end{array}$ & $\begin{array}{l}0.02832 \\
1.233 \\
0.001233\end{array}$ & $\begin{array}{l}\text { cubic meter per second } \\
\text { cubic meter per year } \\
\text { cubic hectometer per year }\end{array}$ \\
\hline
\end{tabular}

Temperature in degrees Celsius $\left({ }^{\circ} \mathrm{C}\right)$ may be converted to degrees Fahrenheit $\left({ }^{\circ} \mathrm{F}\right)$ as follows:

$$
{ }^{\circ} \mathrm{F}=\left(1.8 \times{ }^{\circ} \mathrm{C}\right)+32
$$

Temperature in degrees Fahrenheit $\left({ }^{\circ} \mathrm{F}\right)$ may be converted to degrees Celsius $\left({ }^{\circ} \mathrm{C}\right)$ as follows:

$$
{ }^{\circ} \mathrm{C}=\left({ }^{\circ} \mathrm{F}-32\right) / 1.8
$$

Sea level: In this report, "sea level" refers to the National Geodetic Vertical Datum of 1929 (NGVD of 1929) - a geodetic datum derived from a general adjustment of the first-order level nets of both the United States and Canada, formerly called Sea Level Datum of 1929.

Water year: In U.S. Geological Survey reports, water year is the 12-month period, October 1 through September 30. The water year is designated by the calendar year in which it ends; thus, the water year ending September 30, 1998, is called the "1998 water year."

\section{SYMBOLS AND ABBREVIATIONS USED IN THIS REPORT}

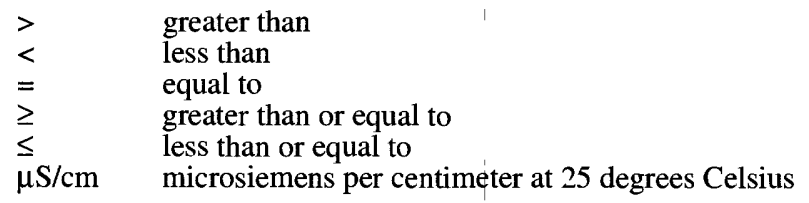




\title{
Lake-Level Frequency Analysis for the Waubay Lakes Chain, Northeastern South Dakota
}

\author{
By Colin A. Niehus, Aldo V. Vecchia, and Ryan F. Thompson
}

\section{ABSTRACT}

In response to significant increases in lake levels in northeastern South Dakota during the 1990 's, a water mass-balance model and a stochastic time-series model were used to perform a lake-level frequency analysis for the Waubay Lakes Chain. The 10 major lakes in the chain include Bitter Lake, Blue Dog Lake, Enemy Swim Lake, Hillebrands Lake, Minnewasta Lake, Pickerel Lake, Rush Lake, Spring Lake, Swan Pond, and Waubay Lake. Lake outlet elevations existing as of April 1999 were used in the frequency analysis.

The water mass-balance model was developed to simulate semiannual lake volumes of the 10 major lakes of the chain using precipitation, evaporation, total inflow to the system, and starting lake levels as input. The model simulated the volumes by accounting for all water entering and leaving each lake.

Historic lake-level data were compiled from all available sources, but most data were obtained from the South Dakota Department of Environment and Natural Resources and the Waubay National Wildlife Refuge. Water years 1963-98 were selected for model development because of the availability of lake-level data. Missing data were generated as needed using regression. Precipitation data were compiled from data collected at the Waubay National Wildlife Refuge, and evaporation data were estimated using a modification of the Morton method.
Because the water mass-balance model estimates lake volumes rather than lake levels, lake area and capacity tables were needed to convert lake levels to lake volumes. Digital contour maps were developed from bathymetric maps and 10-meter digital elevation model data. Bathymetric maps for five of the lakes were available from the South Dakota Department of Game, Fish and Parks. The U.S. Geological Survey collected bathymetric data for the remaining five lakes.

Semiannual total inflow to the Waubay Lakes Chain was estimated using the assumption that the basin containing the lakes chain is a closed system. Total inflow was apportioned among the lakes using regression. Next, flow between lales was incorporated into the model using an iterat ve process, if needed, to balance the level of each lake, taking into account flow from connecting lakes. The iterative process was continued until all lakes were balanced for a particular time step.

Results of the water mass-balance model for each individual lake and for the Waubay Lakes Chain were verified using historic 1963-98 data. The matches between simulated and historic lake levels, areas, and volumes were good.

The stochastic time-series model was developed to generate hypothetical future sequences of semiannual precipitation, evaporation, and total inflow. The model was used to generate two different simulations of 10,000 years of data. Simulation 1 was based on the assumption that 1963-98 is representative of long-term 
climatic conditions. Simulation 2 was based on the assumption that the long-term climatic conditions are slightly drier than the historic 1963-98 climatic conditions. For simulation 2, the precipitation and evaporation data generated for simulation 1 were altered slightly by decreasing the precipitation data by 5 percent and increasing the evaporation data by 3 percent. These changes reduced total inflow by about 15 percent. The historic precipitation, evaporation, and total inflow data fit well with the generated data for both climatic simulations, and the historic data are statistically indistinguishable from the generated data for both simulations.

Frequencies of extreme high or low lake levels generated from the water mass-balance and stochastic time-series models for the two simulations were verified from information on historic lake levels and climate, tree-ring chronologies, and soil surveys. The comparisons between the simulations indicate simulation 2 is much more representative of historic lake-level fluctuations than simulation 1 . Therefore, all frequency results were based on the assumptions used to generate simulation 2.

Because lake levels of closed-basin lakes are characterized by high serial persistence, two frequency analysis methods (unconditional and conditional) were used. Unconditional frequency analysis estimates the frequencies of high or low lake levels for a long time period. Because of the long simulation period, the starting conditions at the beginning of the simulation period have no effect on the analysis. Conditional frequency analysis estimates the frequencies of hypothetical future lake levels for a relatively short time period, such as 50 years. Because of the short time period, the starting conditions at the beginning of the simulation period have an effect on the frequencies of the lake levels. Because studies that relate to flood-risk assessment or flood-mitigation alternatives usually are pertinent only for relatively short time periods into the future, conditional frequency analysis usually is more appropriate than unconditional frequency analysis.

The unconditional frequency analysis was performed for Bitter, Enemy Swim, Pickerel, and
Waubay Lakes using 10,000 years of generated lake levels. The 1-percent exceedan e level for Waubay Lake is at an elevation of $1,811.5 \mathrm{ft}$, which is approximately equal to the closed-basin spill elevation to the Big Sioux River. However, only 13 separate spill events with an average duration of 8 years occurred during the 10,000-year simulation period, giving an average return period of 769 years. Therefore, because of the high serial persistence in the lake levels, the ret irn period corresponding to the 1-percent exceedance level for Waubay Lake is much longer than 100 years.

The lake levels for the 1-percent exceedance probabilities (unconditional analysis) are about $19 \mathrm{ft}$ higher for Bitter Lake, $1.2 \mathrm{ft}$ higher for Enemy Swim Lake, $0.7 \mathrm{ft}$ higher for Pickerel Lake, and $8.6 \mathrm{ft}$ higher for Waubay Lake than the levels of those lakes on April 4, 199?. However, the average return periods are 909 years for Bitter Lake, 185 years for Enemy Swim Lake, 155 years for Pickerel Lake, and 769 years for Waubay Lake. The average return periods for Enemy Swim and Pickerel Lakes for the 0.2-percent erceedance probabilities (unconditional analysis) were 500 years, indicating the extreme high lake levels of the smaller upstream lakes probat'ly are caused by 1-year climatic extremes. However, the average return periods for Bitter anc' Waubay Lakes for the 0.2-percent exceedance probabilities (unconditional analysis) are 2,000 years, indicating the extreme high lake levels of the larger downstream lakes probably are caused by extreme climatic conditions lasting several years.

The conditional frequency anclysis was performed for the 10 major lakes of the Waubay Lakes Chain using 10,000 simulated 50-year lakelevel traces, each starting on October 1, 1998. The generated data can be used to estimate the probability of virtually any event that involves future lake levels.

The upper 1-percent probability bound (conditional analysis) for Waubay Lake indicates that the chance that Waubay Lake w:ll continue to rise to the spill elevation with the Big Sioux River within the next 20 years is relatively high. The lower 1-percent probability bound (conditional analysis) for Waubay Lake indicates that it is 
unlikely that Waubay Lake will return to levels comparable to historic 1960-92 levels for at least 40 years. Also, Waubay Lake is unlikely to return to levels comparable to those during the extreme drought of the 1930's for much longer than 50 years.

An analysis of the upper 10- and 1-percent probability bounds (conditional analysis) for Bitter Lake indicates that the chance that the level of Bitter Lake will continue to significantly increase during the next 15 years is high. An analysis of the lower 10- and 1-percent probability bounds (conditional analysis) for Bitter Lake indicates that Bitter Lake is highly unlikely to return to historic pre-1993 levels for at least 40 years.

The conditional frequency results for Blue Dog Lake, Hillebrands Lake, Minnewasta Lake, Rush Lake, Spring Lake, Swan Pond, and Waubay Lake indicate the upper 10-, 1-, and 0.2-percent probability bounds are about the same for all seven lakes because the lakes are joined at these lake levels.

The lower probability bounds (conditional analysis) for Hillebrands, Minnewasta, Spring, and Waubay Lakes are similar, with each bound decreasing slowly during the entire 50-year simulation period and remaining above pre-1993 historic lake levels for most of the simulation period. Hillebrands, Minnewasta, Spring, and Waubay Lakes are similar to Bitter Lake in that they are unlikely to decrease to "normal" levels for several decades. However, the lower probability bounds (conditional analysis) for Blue Dog Lake and Rush Lake become nearly constant in year 2010 and beyond, indicating that Blue Dog Lake and Rush Lake could return to normal (pre-1993) levels within 10 years.

Because Enemy Swim and Pickerel Lakes spill frequently and never join with the downstream lakes, the upper probability bounds (conditional analysis) for both lakes remain nearly constant for the entire simulation period. Therefore, the levels of both lakes are unlikely to increase significantly over current levels and could return to normal levels much sooner than Bitter Lake or Waubay Lake under a reversal of the current wet conditions.
To illustrate the effects of starting conditions, 10,000 simulated 50-year traces (conditional analysis) for Waubay Lake were generated from the model using October 1, 1962, starting conditions. A comparison of the two sets of starting conditions indicates the upper 1- and 0.2-percent probability bounds (conditional analysis) for Waubay Lake for the 1962 starting conditions take much longer to reach long-term equilibrium levels. However, with dry starting conditions, Waubay Lake can recover quickly and rise rapidly over the course of a few years given a sequenc? of wet years.

Generally, the probability bounds (conditional analysis) produced by the models for ary given exceedance probability eventually converge to the same value, no matter what starting conditions are used. This is because the effect of the starting conditions eventually becomes neglig:ble if the traces are observed for a long enough time.

A climatic scenarios analysis was done to evaluate the hydrologic response of the Waubay Lakes Chain to historic 8-year climatic segments. This was done by inputting historic precipitation and evaporation data (developed for the water mass-balance model) and total inflow data (generated from the stochastic time-series model) into the water mass-balance model to predict resultant lake levels, areas, and volumes. The water massbalance model was used to simulate 25 hypotl' etical 16-year climatic scenarios using all combinations of five descriptive 8-year net lake evaporation segments. The wet-wet scenario, representing two consecutive 1991-98 climatic segments, results in Bitter Lake, after 16 years. increasing 22.2 feet above the starting lake lerrel and Waubay Lake increasing 11.1 feet. The average-average scenario, representing two consecutive 1985-92 climatic segments, results ir little change in the levels of Bitter and Waubay Lakes. The dry-dry scenario, representing two consecutive 1969-76 climatic segments, results in Bitter Lake, after 16 years, declining 6.6 feet fom the starting lake level and Waubay Lake declining 10.4 feet.

The conditional frequency analysis performed for Waubay Lake with October 1, 199?, 
starting conditions was compared to the scenario results. The five selected scenarios seem to represent the full range of hypothetical future lake levels. The lake levels after 16 years range from about the lower 1-percent probability bound for the dry-dry scenario to about the upper 0.2-percent probability bound for the wet-wet scenario.

\section{INTRODUCTION}

The Waubay Lakes Chain is located in Day County in a $409-\mathrm{mi}^{2}$ closed subbasin of the Big Sioux River Basin, northeastern South Dakota. The 10 major lakes in this chain are Bitter Lake, Blue Dog Lake, Enemy Swim Lake, Hillebrands Lake, Minnewasta Lake, Pickerel Lake, Rush Lake, Spring Lake, Swan Pond, and Waubay Lake.

Significant increases in lake levels within the Waubay Lakes Chain have occurred during the 1990's, mainly because of greater-than-normal precipitation along with less-than-normal evaporation. Saturated soil conditions within the basin containing the Waubay Lakes Chain have resulted in high runoff even for small storms. Many of the kettles, ponds, and wetlands have filled to overflowing and now contribute substantially more inflow to the lakes than in the past. Also, several of the lakes that were separate lakes before 1993 have combined to form one lake. The rising lake levels have resulted in substantial damage to public and private property in the basin. Numerous public roads and highways have been damaged or closed because of high water, and some have been raised at great cost. Many parks and recreational facilities also have been adversely affected. Thousands of acres of farmland and numerous farmsteads, homes, and lake-front properties have been inundated or have been damaged by flooding, waves, and seepage.

The Federal Emergency Management Agency (FEMA) declared Day, Clark, Marshall, and Spink Counties in northeastern South Dakota a Federal Disaster Area (FEMA-1218-DR) on June 1, 1998. As a result of this declaration, an interagency team was formed to conduct an interdisciplinary scientific study of the rising high lake levels in Day County. Agencies represented included FEMA, the U.S. Geological Survey (USGS), the U.S. Army Corps of Engineers (USACE), South Dakota State University (SDSU), the Natural Resources Conservation Service (NRCS), the South Dakota Department of Environment and Natural
Resources (SDDENR), the South Dakota Geological Survey (SDGS), and the South Dakota Division of Emergency Management (SDDEM). The purpose of the study, which was divided into five tasks, was to obtain information on the high lake leve's, the possible causes of the high lake levels, and the frobabilities of future lake levels of the Waubay Lakes Chain. The information is needed by FEMA and other public and private entities to assess and possibly mitigate further damage to public and private property ir the basin. The USGS entered into a contractual agreement with FEMA for fiscal years 1998-99 to provide part of the information. The remaining informaticn will be provided by the USACE and SDSU. The tasks are numbered and described as follows:

- Task 1 - History of inundation (1992-98)

- Task 2 - Predictive modeling based on climatic scenarios

- Task 3 - Long-term estimates of historical lakelevel chronologies

- Task 4 - Water balance and lake-level frequency analysis

- Task 5 - Hydrologic modeling ard evaluation of mitigation alternatives (accomplished by USACE)

\section{Purpose and Scope}

This report documents results of task 4 , which involves using a water mass-balance model and a stochastic time-series model for a lake-level frequency analysis for the Waubay Lakes Chain in northeastern South Dakota, and provides a brief summary of the results of task 2. The report describes a water massbalance model that simulates semiannual lake volumes; a stochastic time-series model that simulates hypothetical future sequences of semiannual precipitation, evaporation, and total inflow; and a lake-level frequency analysis for the 10 major lakes of the Waubay Lakes Chain. The lake-level frequencies were developed using the water mass-balance model in conjunction with the stochastic time-series model.

The water mass-balance model was developed to simulate semiannual lake volumes of the 10 lakes using precipitation, evaporation, total inflow to the system, and starting lake levels as input. The model simulates the volumes by accounting for all water entering and leaving each lake. The model was constructed and verified using historic 1963-98 lake-level, precipitation, and evaporation data. 
The stochastic time-series model was developed to generate hypothetical future sequences of semiannual precipitation, evaporation, and total inflow. The model was constructed and verified using historic 1963-98 precipitation, evaporation, and total inflow data.

Because lake levels of closed-basin lakes are characterized by high serial persistence, two frequency analysis methods (unconditional and conditional) were used. Unconditional frequency analysis estimates the frequencies of high or low lake levels for a long time period during which the lake levels cycle many times between wet and dry periods. The starting conditions at the beginning of the simulation period have no effect on the analysis because of the long simulation period. Unconditional frequency analysis was performed for Bitter, Enemy Swim, Pickerel, and Waubay Lakes using 10,000 years of generated lake levels. Conditional frequency analysis, or position analysis, estimates the frequencies of hypothetical future lake levels for a relatively short time period, such as 50 years. Because of the short time period, the starting conditions at the beginning of the simulation period have an effect on the frequencies of the lake levels. The conditional frequency analysis was performed for the 10 major lakes of the Waubay Lakes Chain using 10,000 simulated 50-year lake-level traces, each starting on October 1, 1998. The generated data can be used to estimate the probability of virtually any event that involves future lake levels.

The conditional frequency analysis also involved describing the sensitivity of the models to starting conditions and describing the results of various historic 16-year climatic scenarios that may or may not occur in the future.

\section{Description of Study Area}

The study area is located in the upper Big Sioux River Basin in Day, Grant, Marshall, and Roberts Counties in extreme northeastern South Dakota (fig. 1). The $409-\mathrm{mi}^{2}$ study area is composed of 10 subbasins corresponding to the 10 major lakes of the Waubay Lakes Chain. The lake connections between these 10 lakes of the Waubay Lakes Chain are shown schematically in figure 2. Presently, the Waubay Lakes Chain Basin is closed; however, if greater-than-normal precipitation and less-than-normal evaporation continue, the basin potentially could begin contributing runoff to the Big Sioux River.

\section{Physiography and Climate}

The study area is located entirely in the Coteau des Prairies, a highland plateau between the Minnesota River-Red River lowlands to the east and the James River lowland to the west (fig. 3) (Flint, 1955). The Coteau des Prairies, or Prairie Hills, received its name from early trappers in the region (Gries, 1996) and often is described as having the shape of a household iron. The apex of the Coteau des Prairies, which is oriented approximately north-south, extends slightly into North Dakota, and the south edge terminates in northwestern Iowa and southwestern Minnesota. The Coteau des Prairies has an average width of $50 \mathrm{mi}$ and maximum elevations more than $2,100 \mathrm{ft}$ above sea level. It is as much as $900 \mathrm{ft}$ above the Minnesota River-Red River lowlands to the east and as much as $400 \mathrm{ft}$ above the James River lowlands to the west. The Coteau des Prairies is characterized by a rugged, poorly drained landscape, especially in its upper regions where the study area is located. The land is hummocky to rolling but has occasional flat areas where lakes were located during Pleistocene time. Many large lakes and thousands of kettles, ponds, and wetlands dot the terrain as a result of glacial stagnation during late Wisconsin time (Leap, 1988). As the levels of the individual lakes have risen, many of the lakes have combined and overflowed into the subbasins of adjacent lakes. The Big Sioux and James Rivers are the only major streams that drain the Coteau des Prairies in the vicinity of the study area.

The climate of the Coteau des Prairies generally can be classified as subhumid. Precipitation averages 20 to $22 \mathrm{in} / \mathrm{yr}$, and the growing season is 110 to 140 days. The average minimum January temperature is $1^{\circ} \mathrm{F}$, the average maximum January temperature is $21^{\circ} \mathrm{F}$, the average minimum July temperature is $60^{\circ} \mathrm{F}$, and the average maximum July temperature is $85^{\circ} \mathrm{F}$ (Bryce and others, 1998).

National Weather Service stations within the study area are located at Webster and Waubay National Wildlife Refuge (fig. 1). The Webster station is located about 0.2 mi northwest of the post office at Webster, S. Dak., and the Waubay National Wildlife Refuge station is located at the Refuge headquarters. Precipitation and temperature data have been collected at the Webster station since October 1898. Precipitation data have been collected at the Waubay National Wildlife Refuge station since May 1952. Annual precipitation and temperature statistics for the two stations are given in table 1. 


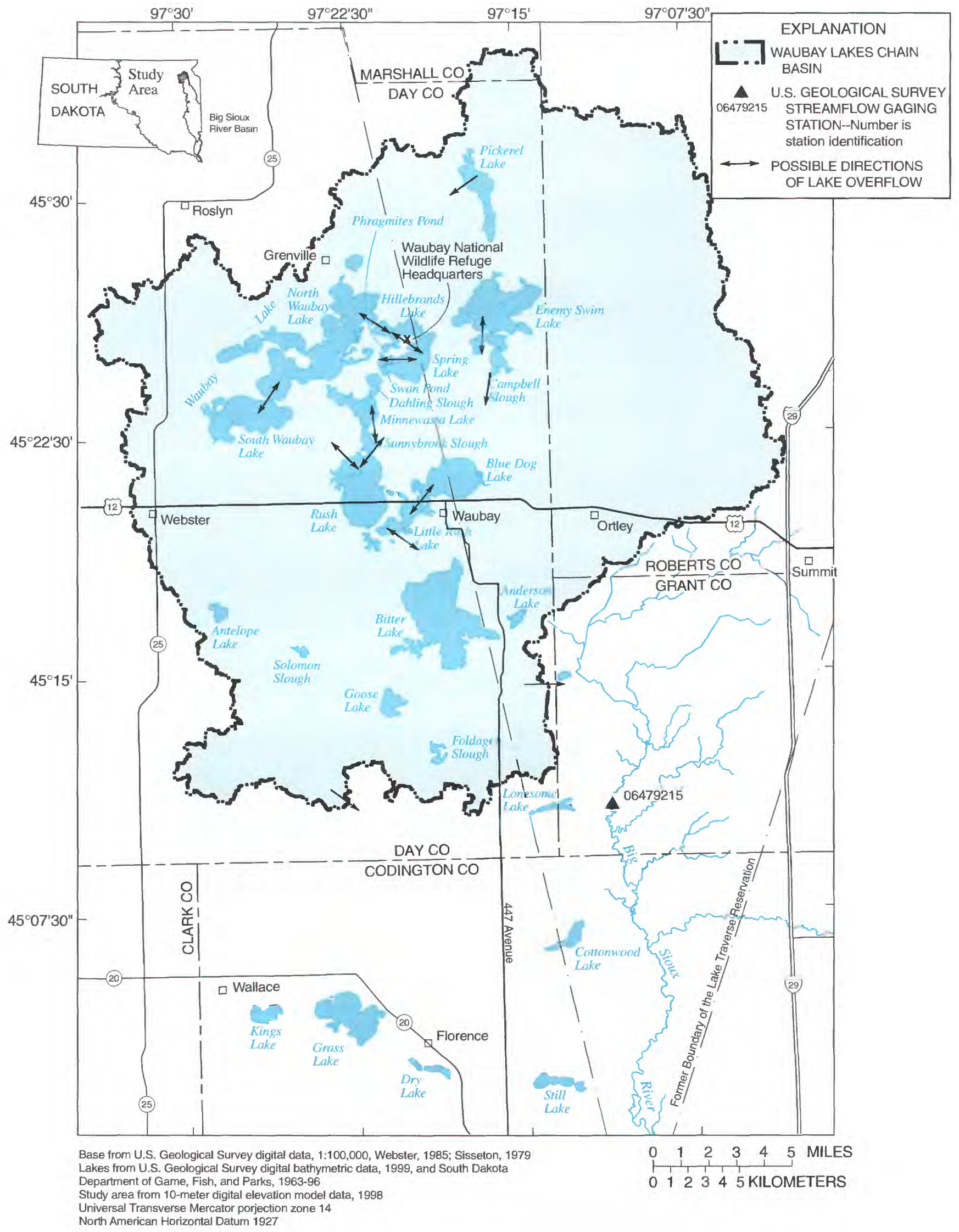

Figure 1. Location of study area. 


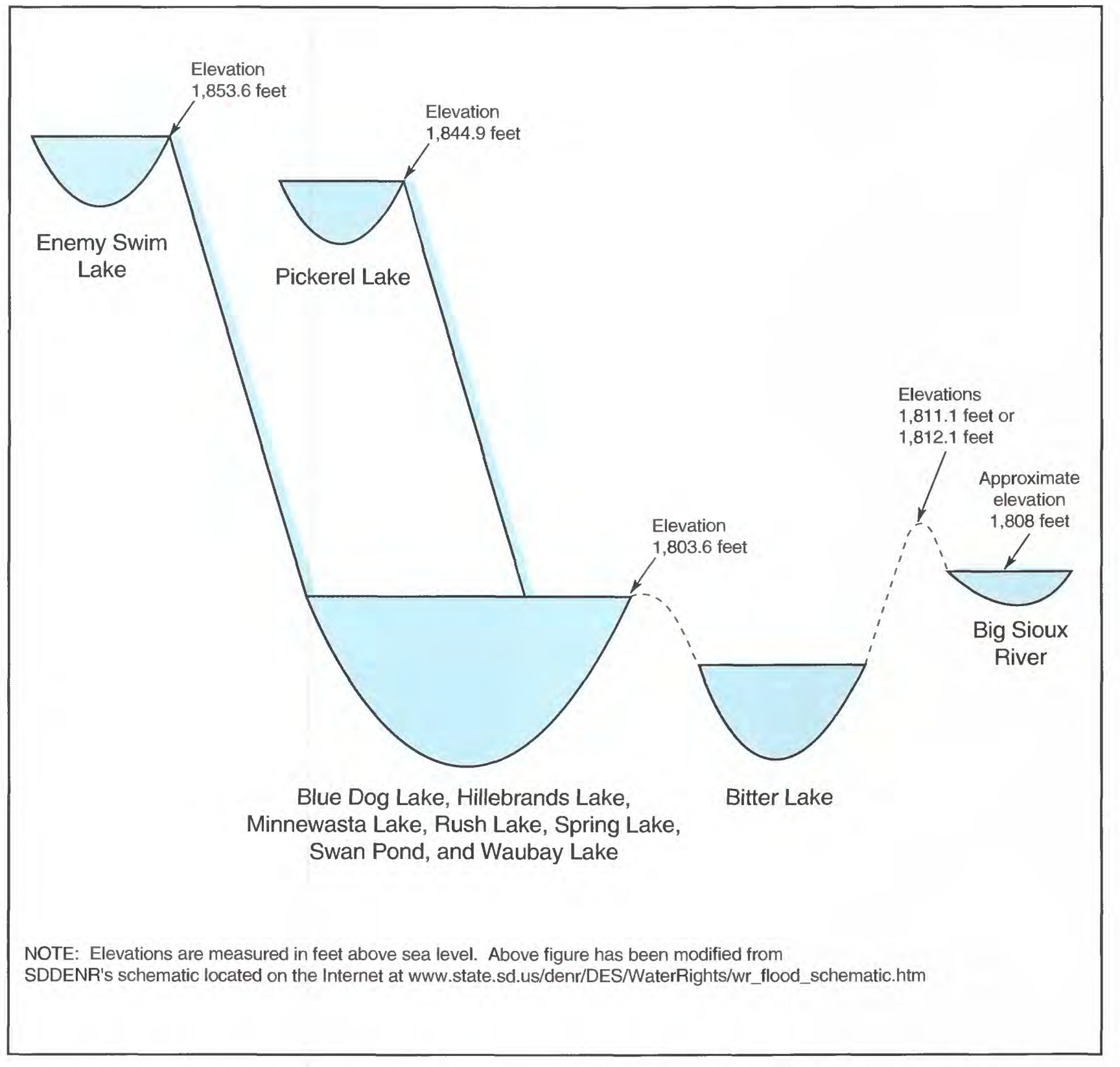

Figure 2. Lake connections for the Waubay Lakes Chain. 


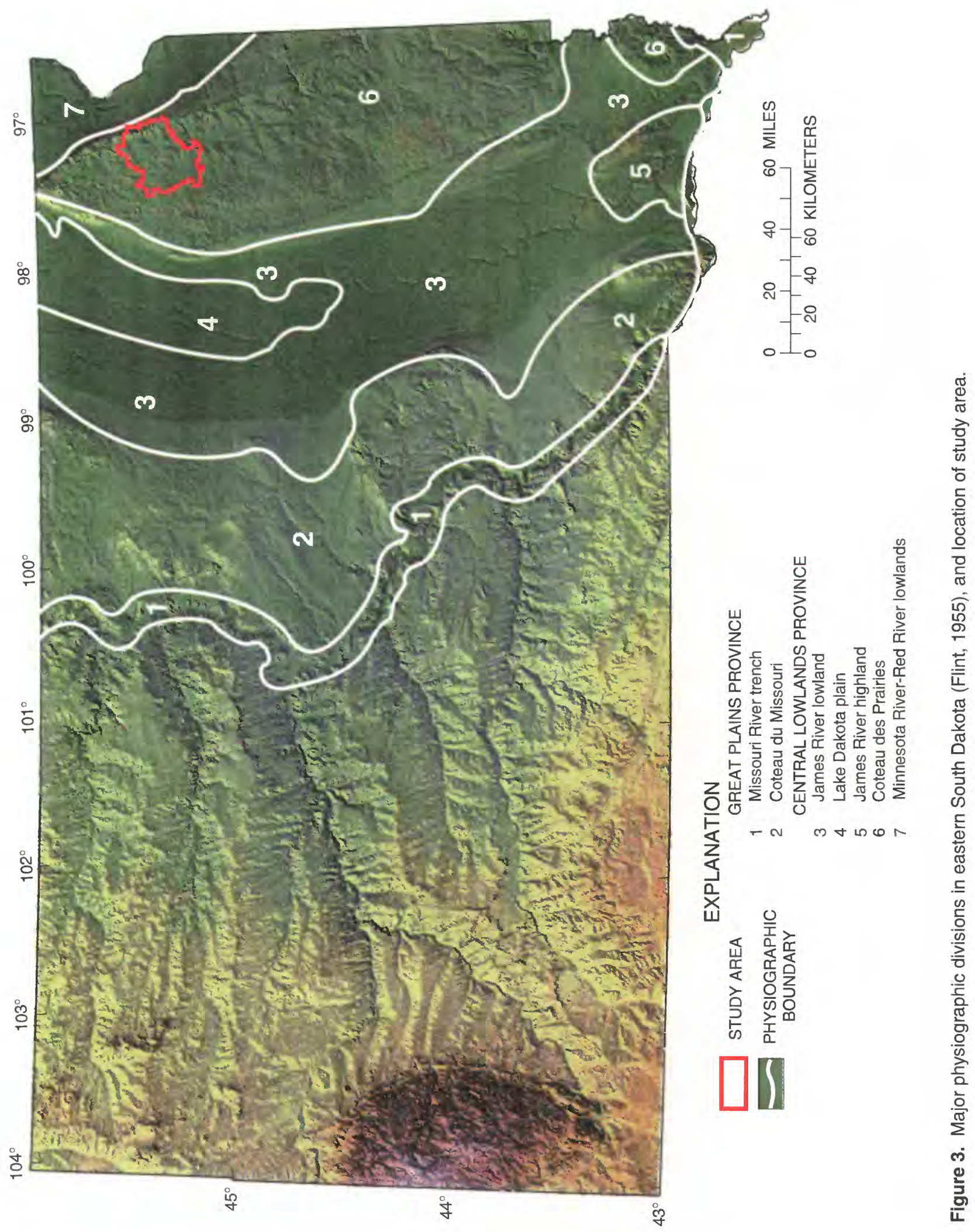


Table 1. Annual precipitation and temperature statistics for Webster and Waubay National Wildlife Refuge National Weather Service stations

[Waubay NWR, Waubay National Wildlife Refuge; --, not available; $\geq$, greater than or equal to; ${ }^{\circ} \mathrm{F}$, degrees Fahrenheit; $\leq$, less than or equal to]

\begin{tabular}{|c|c|c|}
\hline \multirow[b]{2}{*}{ Precipitation and temperature } & \multicolumn{2}{|c|}{ Location } \\
\hline & Webster & $\begin{array}{c}\text { Waubay } \\
\text { NWR }\end{array}$ \\
\hline Average precipitation ${ }^{1}$ (inches) & 21.06 & 20.37 \\
\hline Total snowfall ${ }^{2}$ (inches) & - & 32.4 \\
\hline $\begin{array}{l}\text { Mean number of days with precipita- } \\
\text { tion } \geq 0.10 \mathrm{inch}^{2} \text { (days per year) }\end{array}$ & 45 & 45 \\
\hline $\begin{array}{l}\text { Mean number of days with precipita- } \\
\text { tion } \geq 0.50 \text { inch }^{2} \text { (days per year) }\end{array}$ & 11 & 12 \\
\hline Mean temperature ${ }^{1}\left({ }^{\circ} \mathrm{F}\right)$ & 43.1 & 43.2 \\
\hline $\begin{array}{l}\text { Mean daily minimum temperature }{ }^{1} \\
\quad\left({ }^{\circ} \mathrm{F}\right)\end{array}$ & 31.5 & 31.5 \\
\hline $\begin{array}{l}\text { Mean daily maximum temperature }{ }^{1} \\
\quad\left({ }^{\circ} \mathrm{F}\right)\end{array}$ & 54.6 & 54.9 \\
\hline $\begin{array}{l}\text { Mean number of days with temperature } \\
\geq 90^{\circ} \mathrm{F}^{2} \text { (days per year) }\end{array}$ & 17 & -- \\
\hline $\begin{array}{l}\text { Mean number of days with temperature } \\
\leq 32^{\circ} \mathrm{F}^{2} \text { (days per year) }\end{array}$ & 182 & -- \\
\hline
\end{tabular}

${ }^{1}$ Normal for 1961-90 (U.S. Department of Commerce, 1998).

${ }^{2}$ Average for 1951-60 (U.S. Department of Commerce, 1965).

Pan evaporation data are not available for either of the two stations located within the study area. The two nearest stations for which data are available are located at Redfield (about $90 \mathrm{mi}$ southwest of Waubay) and Brookings (about $75 \mathrm{mi}$ south-southeast of Waubay). Data for the Redfield station are available from 1949 to 1978 and 1985 to present (1998), and data for the Brookings station are available from 1953 to present (1998). Pan evaporation data are not collected throughout the year because the apparatus can operate only when temperatures are consistently above freezing. Therefore, data typically are available for May through September and occasionally for April and October. Data for the remainder of the year must be estimated. The average May-through-September pan evaporation for the period of record is $37.58 \mathrm{in}$. at Redfield and 39.25 in. at Brookings (U.S. Department of Commerce, 1950-98).

\section{Surface Water}

Many lakes and small depressions dot the surface of the study area (fig. 1). The largest lakes are glacial in origin and include Bitter Lake, Blue Dog Lake, Enemy Swim Lake, Pickerel Lake, Rush Lake,
Spring Lake, and Waubay (North and South) Lake. The smaller lakes are also glacial in origin and include Hillebrands Lake, Minnewasta Lake, and Swan Pond. Other small lakes and named depressions include Little Rush Lake, Campbell Slough, Dahling Slough, Surnybrook Slough, and Phragmites Pond. The arrows shown in figure 1 denote the approximate location of lake connections or spill points. Single-headed arrows indicate that flow occurs only in one direction, whereas two-headed arrows indicate that flow may occur in either direction depending on the relative water levels of the lakes involved. A more thorough description of lake connections and spill points is included in the discussion of drainage basins later in this report. Although no major rivers flow through Day Count;, tributaries to the Big Sioux River flow through the southeastern part of the county, and tributaries to th James River flow through the western part of the county. Total drainage area of the closed-basin study area is about $409 \mathrm{mi}^{2}$ (Glenn Kelly, Earth Resources Observation System Data Center, written commun., 1999).

\section{Lakes}

Characteristics of the 10 major lakes of the Waubay Lakes Chain are given in table 2 and described in the next several paragraphs. Unless otherwise noted, Enemy Swim Lake includes Campbell Slough, Hillebrands Lake includes Phragmites Pond, Minnewas ${ }^{\dagger} a$ Lake includes Dahling and Sunnybrook Sloughs, Rush Lake includes Little Rush Lake, and Waubay Lake includes North and South Waubay Lakes. Area and volume data presented throughout this report are based on output of a geographic information system (GIS). Numbers are often presented to one decimal place to avoid apparent inconsistencies that could result from rounding. This is not meant to imply a high precis in of area and volume data. Photographs of selected lakes are shown in section A of the Supplemental Information section at the end of this report. Historic lake levels through April 7, 1999, are given in section $\mathrm{E}$ of the Supplemental Information section, and lake levels measured on that date are referred to as "present" lake levels in this report. The ordinary high-water mart (OHWM) given in table 2 is the maximum lake level reached during normal climatic conditions rather th an the maximum lake level reached during peak conditions. The OHWM's are established by the SDDENR by taking into account shorelines, tree bases, erosion marks, outlet structures, soil types, land uses, and lake levels. 


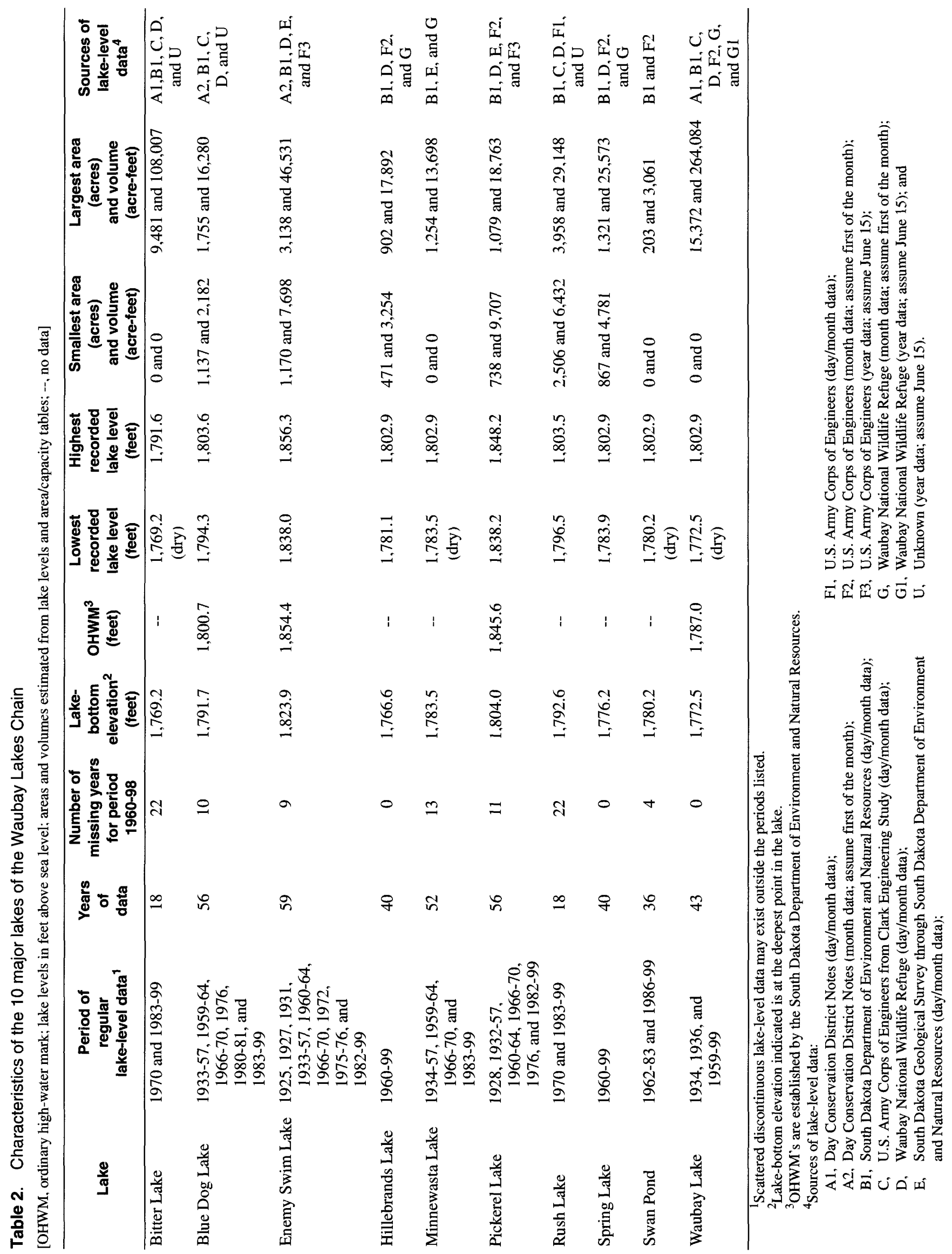


Bitter Lake is a shallow, flat-bottomed lake that has a large surface area at shallow depths. During periods of normal rainfall, it is characterized by many unconnected filled potholes. The lake is about $1.4 \mathrm{mi}$ wide from east to west and $3.3 \mathrm{mi}$ long from north to south at an elevation of $1,775 \mathrm{ft}$. For 1970 and 1983-99, the depth ranged from near 0 to $22.4 \mathrm{ft}$, and the storage ranged from near 0 to 108,000 acre- $\mathrm{ft}$ (table 2). Presently, Bitter Lake is the second largest lake in area and volume. Bitter Lake at its highest recorded lake level has about 62 percent of the area and 41 percent of the volume of Waubay Lake at its highest recorded lake level.

Blue Dog Lake also is a shallow, flat-bottomed lake that has a large surface area at shallow depths. The lake is about $2.3 \mathrm{mi}$ long from east to west and $1.4 \mathrm{mi}$ wide from north to south at an elevation of $1,800 \mathrm{ft}$. For most of 1933-99, the depth ranged from 2.6 to $11.9 \mathrm{ft}$, and the storage ranged from about 2,180 to 16,300 acre-ft (table 2). Blue Dog Lake at its highest recorded lake level has about 11 percent of the area and 6 percent of the volume of Waubay Lake at its highest recorded lake level.

Enemy Swim Lake is a steep-sided, flatbottomed lake that is shallow on the northeastern end and joins Campbell Slough on the southern end. The lake is about $1.9 \mathrm{mi}$ wide from east to west and $3.0 \mathrm{mi}$ long from north to south at an elevation of $1,854 \mathrm{ft}$. For most of 1925-99, the depth ranged from 14.1 to $32.4 \mathrm{ft}$, and the storage ranged from about 7,700 to 46,500 acre-ft (table 2). Presently, Enemy Swim Lake is the fourth largest lake in area and the third largest lake in volume. Enemy Swim Lake at its highest recorded lake level has about 20 percent of the area and 18 percent of the volume of Waubay Lake at its highest recorded lake level.

Hillebrands Lake is a steep-sided lake that has a flat bottom in the western half and a v-shaped, deeper bottom in the eastern half. The lake is about $1.6 \mathrm{mi}$ long from east to west and $0.5 \mathrm{mi}$ wide from north to south at an elevation of $1,785 \mathrm{ft}$. For 1960-99, the depth ranged from 14.5 to $36.3 \mathrm{ft}$, and the storage ranged from about 3,250 to 17,900 acre-ft (table 2). Hillebrands Lake at its highest recorded lake level has about 6 percent of the area and 7 percent of the volume of Waubay Lake at its highest recorded lake level.

Minnewasta Lake is a shallow, flat-bottomed lake. It is about $2.0 \mathrm{mi}$ long from northwest to southeast and ranges from about $0.3 \mathrm{mi}$ wide in the northwest to $0.8 \mathrm{mi}$ wide in the southeast at an elevation of
1,795 ft. For 1934-70 and 1983-99, the depth rarged from near 0 to $19.4 \mathrm{ft}$, and the storage ranged from near 0 to 13,700 acre-ft (table 2). Minnewasta Lake at its highest recorded lake level has about 8 percent of the area and 5 percent of the volume of Waubay Lake at its highest recorded lake level.

Pickerel Lake is a steep-sided lake that has a $\mathrm{v}$-shaped bottom. The lake is about $0.5 \mathrm{mi}$ wide from east to west and $3.3 \mathrm{mi}$ long from north to south at an elevation of $1,845 \mathrm{ft}$. For most of 1928-99, the d:pth ranged from 34.2 to $44.2 \mathrm{ft}$, and the storage ranged from about 9,710 to 18,800 acre-ft (table 2). Pickerel Lake at its highest recorded lake level has about 7 percent of the area and volume of Waubay Lake at its highest recorded lake level.

Rush Lake is a shallow, flat-bottomed lake that has a large surface area at shallow depths. The leke is about $1.6 \mathrm{mi}$ wide from east to west and $2.6 \mathrm{mi}$ long from north to south at an elevation of $1,800 \mathrm{ft}$. Frr 1970 and 1983-99, the depth ranged from 3.9 to $10.9 \mathrm{ft}$, and the storage ranged from about 6,430 to 29,100 acre-ft (table 2). Presently, Rush Lake is the third largest lake in area and the fourth largest lal e in volume. Rush Lake at its highest recorded lake lavel has about 26 percent of the area and 11 percent of the volume of Waubay Lake at its highest recorded lake level.

Spring Lake is a steep-sided, flat-bottomed lake that is approximately triangular in shape. The lake is about $1.8 \mathrm{mi}$ wide from east to west and $1.8 \mathrm{mi}$ long from north to south at an elevation of $1,790 \mathrm{ft}$. For 1960-99, the depth ranged from 7.7 to $26.7 \mathrm{ft}$, and the storage ranged from about 4,780 to 25,600 acre-ft (table 2). Spring Lake at its highest recorded lake level has about 9 percent of the area and 10 percent of the volume of Waubay Lake at its highest recorded lake level.

Swan Pond is a flat-bottomed lake. It is about $0.6 \mathrm{mi}$ long from east to west and 0.4 wide from north to south at an elevation of $1,790 \mathrm{ft}$. For most of 1962-83 and 1986-99, the depth ranged from near 0 to $22.7 \mathrm{ft}$, and the storage ranged from near 0 to about 3,060 acre-ft (table 2). Swan Pond is by far the smallest lake in area and volume. Swan Pond at its highest recorded lake level has about 1 percent of the area and volume of Waubay Lake at its highest recorded lake level.

Waubay Lake is a shallow, flat-bottomed lake that has relatively steep-sided slopes and a large surface area at shallow depths. The lake is about $3.0 \mathrm{mi}$ 
wide from northwest to southeast and $9.0 \mathrm{mi}$ long from northeast to southwest at an elevation of $1,795 \mathrm{ft}$. For 1960-99, the depth ranged from near 0 to $30.4 \mathrm{ft}$, and the storage ranged from near 0 to 264,000 acre-ft (table 2). Waubay Lake is by far the largest lake in area and volume. Waubay Lake at its highest recorded lake level has about 160 percent of the area and 240 percent of the volume of Bitter Lake (the second largest lake) at its highest recorded lake level.

The lakes of the Waubay Lakes Chain usually are at their highest levels in May because of runoff from snowmelt and spring rains. Although the greatest amount of precipitation usually occurs in June, the precipitation is counteracted by increased evaporation during the summer. The lakes generally are at their lowest levels in November or December.

The lake levels, areas, and volumes of the Waubay Lakes Chain have increased substantially from May 1993 to April 1999. The areas and volumes given in table 3 and shown in figures 4 and 5 were derived from area/capacity equations that will be discussed later. Additional data are presented in a later section on historic lake levels. Lake-level rises for Bitter Lake, Hillebrands Lake, Spring Lake, Swan Pond, and Waubay Lake have ranged from 15.1 to $18.6 \mathrm{ft}$ (table 3). The area of the entire Waubay Lakes Chain is about 1.7 times greater than in May 1993, and the volume is about 3.2 times greater than in May 1993. Individually, the area of Bitter Lake is about 2.7 times greater than in 1993, the areas of Swan Pond and Waubay Lake are about 2 times greater, the area of Hillebrands Lake is about 1.7 times greater, and the area of Rush Lake is about 1.3 times greater. The volumes of Bitter Lake and Swan Pond are about 10 times greater than in 1993, the volume of Waubay Lake is about 5 times greater, and the volume of Rush Lake is about 2 times greater. Enemy Swim and Pickerel Lakes are the only lakes that have had stable lake levels during 1993-99. These lakes spill to the other lakes in the chain, and the spill is not affected by backwater because they are at much higher elevations than the other lakes.

The areal and volumetric distributions of the 10 major lakes of the Waubay Lakes Chain for May 1993 and April 1999 are shown in figures 6 and 7. The area or volume of an individual lake is shown as a percentage of the total area or volume of the chain.

Based on discussions with Derric Iles (South Dakota Geological Survey, oral commun., 1999), ground-water flow to the lakes was assumed to be minimal. However, some evidence indicates that the area of Spring Lake shown in section A of the Supplemental Information section probably receives some groundwater inflow indirectly from Enemy Sw'm Lake.

Few water-quality data are availab ${ }^{1}$ for the lakes within the study area. Petri and Larson (1968) summarized the quality of water in lakes in eastern South Dakota using data for 1961-65; The State Lakes Preservation Committee (1977) presented a brief overview of lakes in northeastern South Dakota and a compilation of some existing data; Leap $\left(19^{\circ} 8\right)$ presented dissolved solids data collected during 1069-70; and Steuven and Stewart (1996) presented water-quality data, including field measurements, nutrients, and algal species, for 1989-92. Previous editions of lakeassessment reports published by the SDDENR also are available.

Specific conductance data for the 10 major lakes were collected by the USGS in 1995 and 1999. These data, along with data collected previously, are given in table 4. Specific conductance, or condu tivity, is a measure of the electrical conductance of a substance normalized to unit length and unit cross section at a specified temperature. Specific conductance is a function of the types and quantities of dissolved substances in water. As ion content increases in water, so does specific conductance. Specific conductance also can be used to estimate the concentration of dissolved solids in water. Commonly, the concentration of dissolved solids (in milligrams per liter) is about 65 percent of the specific conductance (in microsiemens) (Hem, 1985).

Blue Dog, Enemy Swim, and Piclerel Lakes spill often during average climatic cond tions and generally have lower dissolved solids than the other lakes within the Waubay Lakes Chain. Measured specific conductance for Blue Dog, Enemy Swim, and Pickerel Lakes has ranged from 350 to $097 \mu \mathrm{S} / \mathrm{cm}$ (table 4). Bitter Lake generally has high ar specific conductance values than the other nine lakes within the basin. Before the high inflows that have occurred since 1993, specific conductance values for Bitter Lake ranged from 5,820 to $33,800 \mu \mathrm{S} / \mathrm{cm}$ (specific conductance values were not available for Bitter Lake for dry years such as 1961 and 1976).

Additional water-quality information would be beneficial, especially if the Waubay Lakes Chain begins to naturally spill to the Big Sioux River or if mitigation alternatives (task 5) utilizing diversions are planned. Understanding the water-quality effects of water from the Waubay Lakes Chain on the Big Sioux River would be important. 

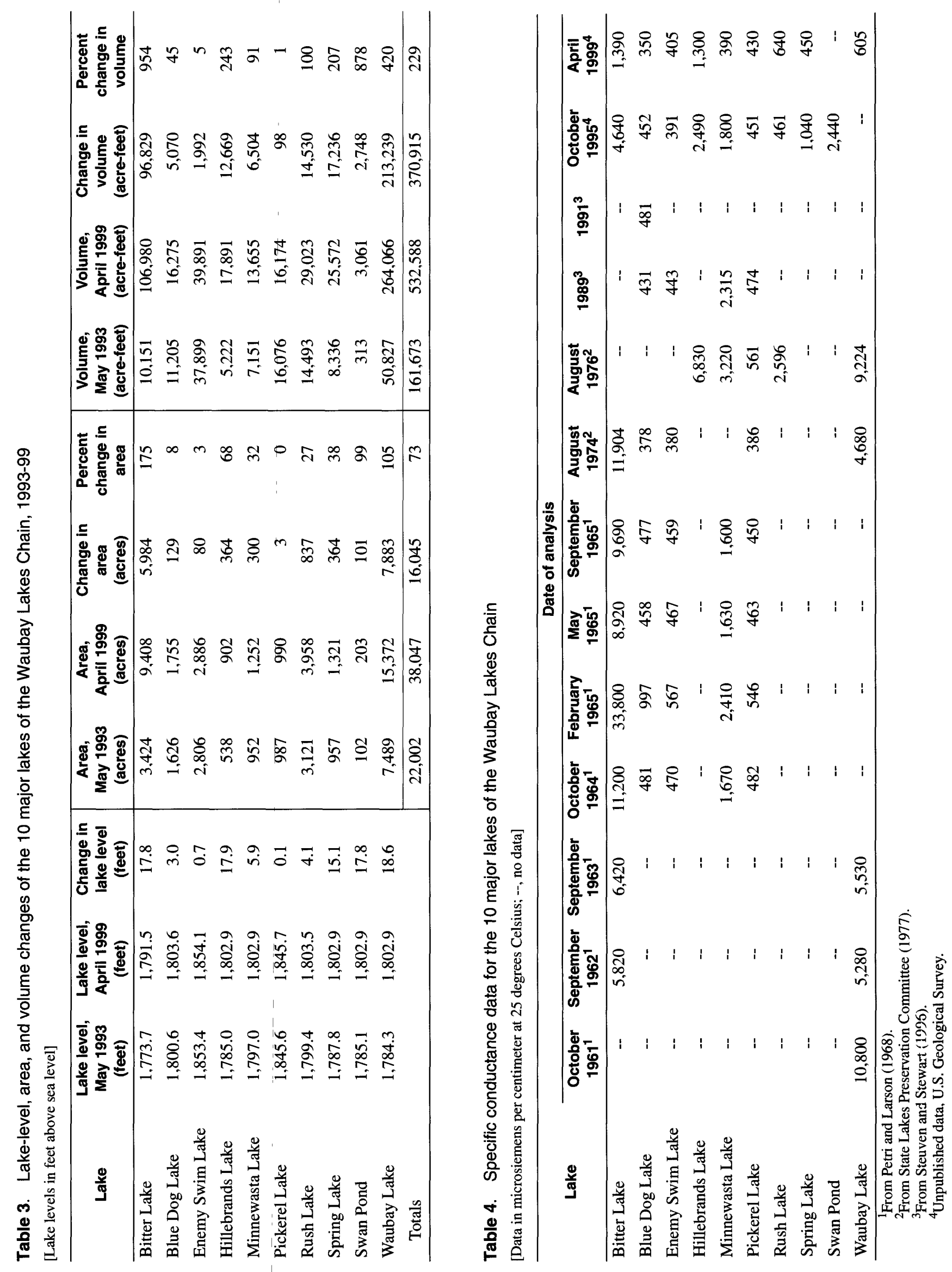
Bitter Lake

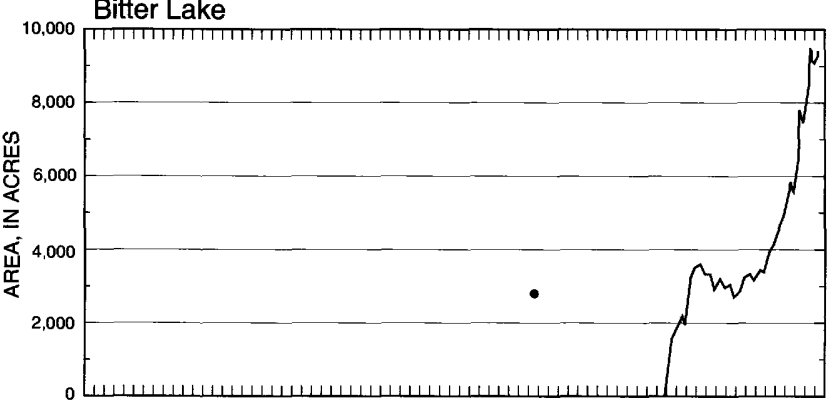

Blue Dog Lake

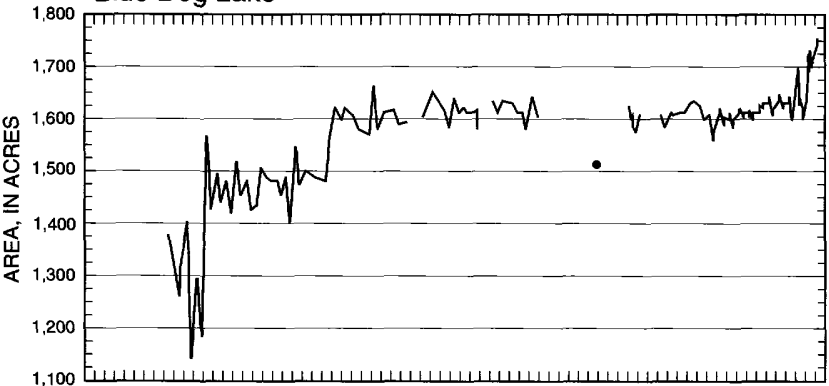

Enemy Swim Lake

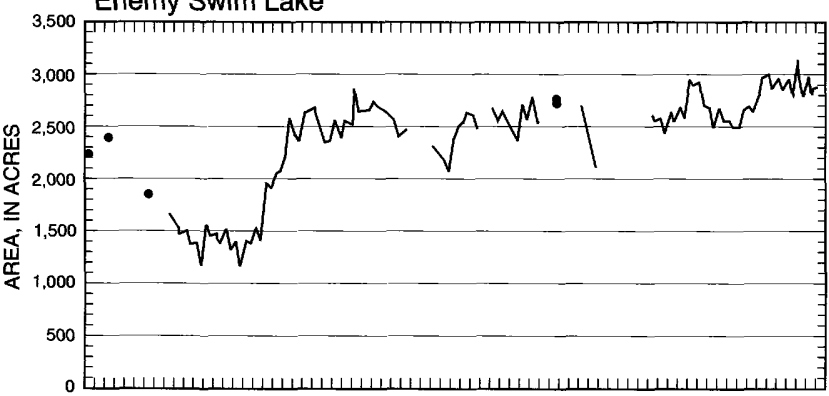

Hillebrands Lake

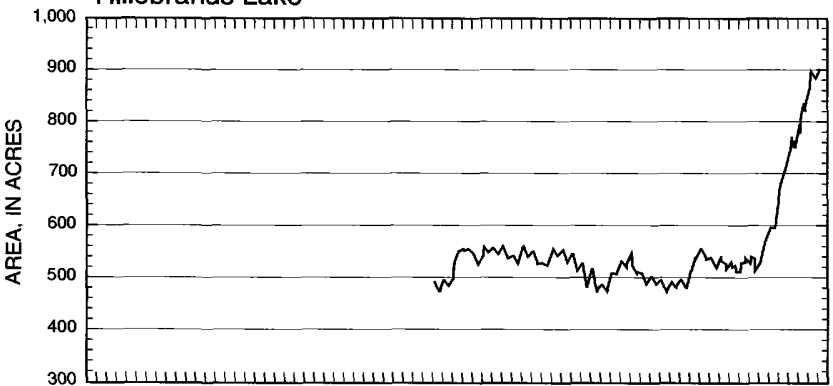

Minnewasta Lake

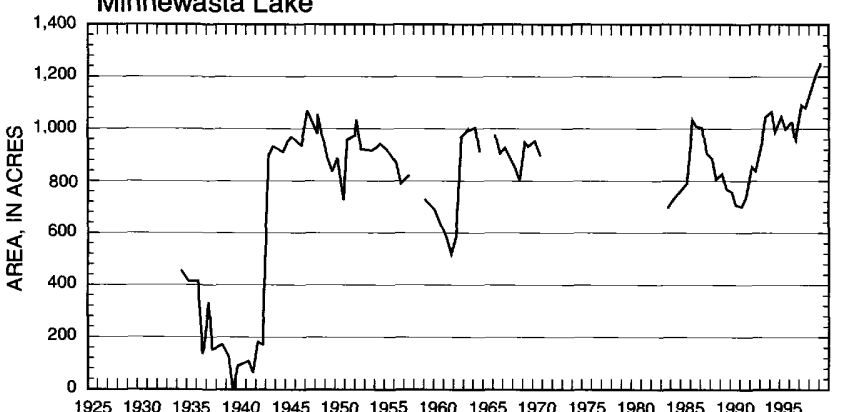

Pickerel Lake

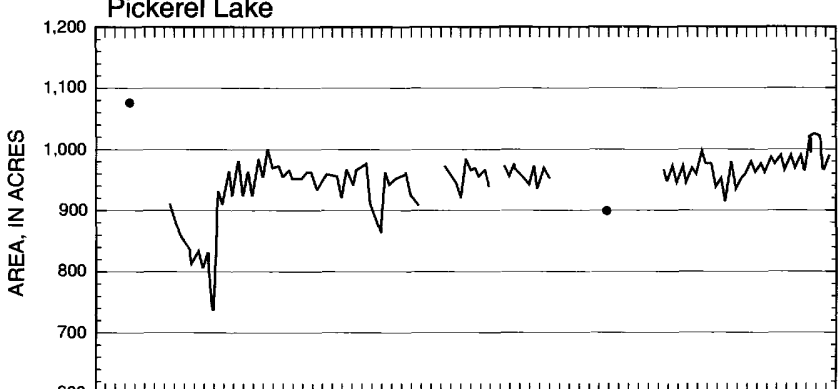

Rush Lake

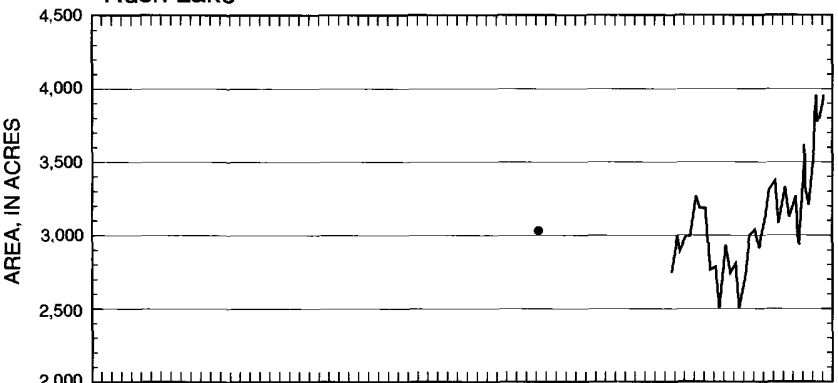

Spring Lake

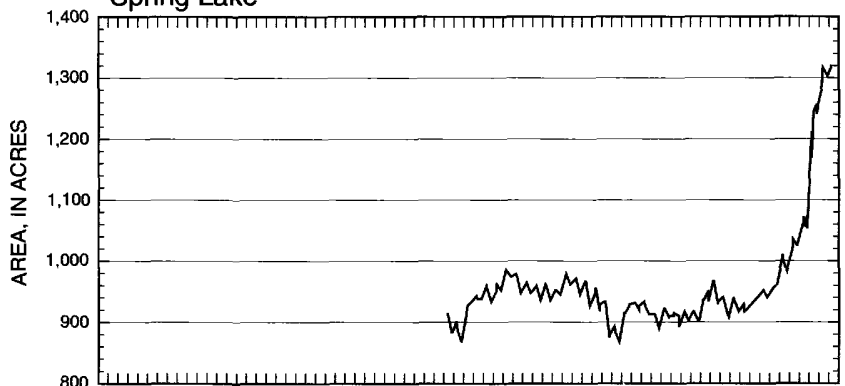

Swan Pond

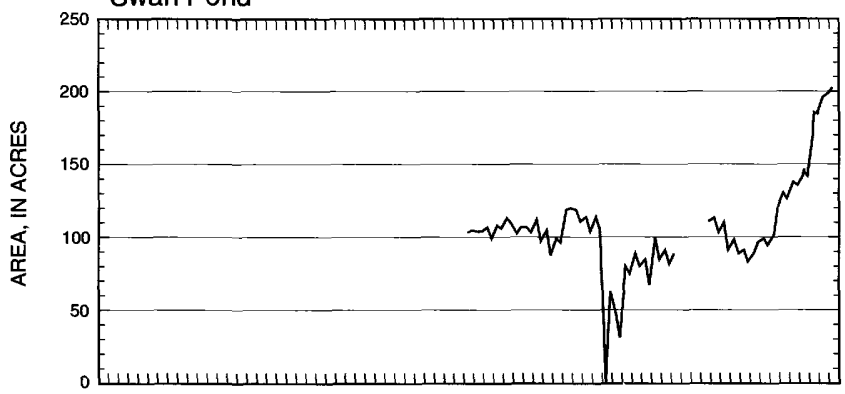

Waubay Lake

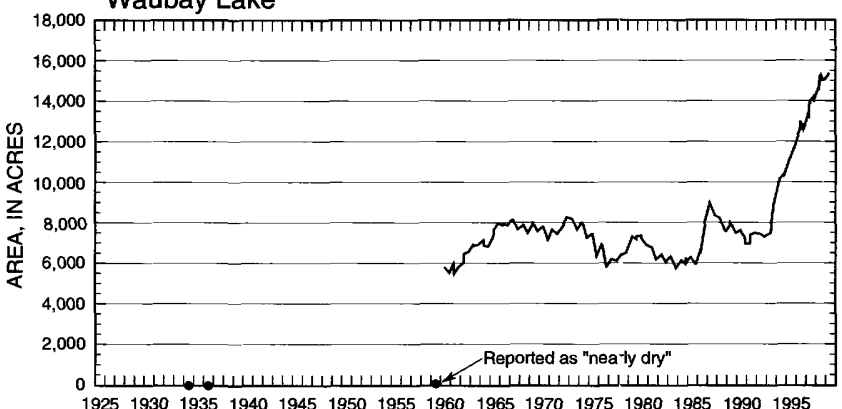

\section{EXPLANATION}

M-M BLANK AREAS REPRESENT MISSING DATA GREATER
THAN 12 MONTHS DURATION

- INDIVIDUAL READING

Figure 4. Historic area of individual lakes within the Waubay Lakes Chain. 
Bitter Lake

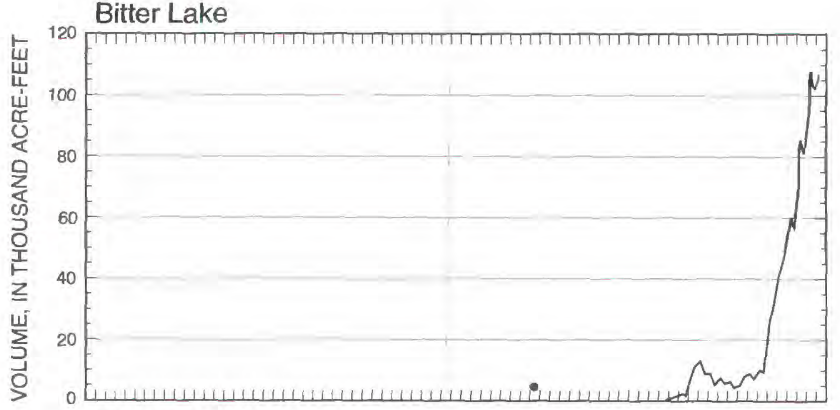

Blue Dog Lake

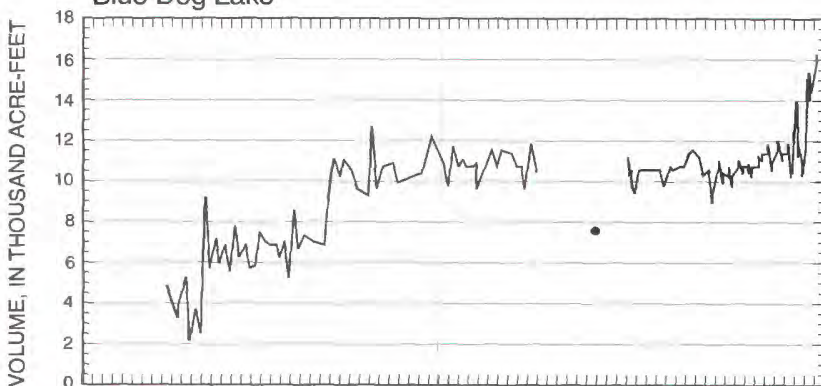

Enemy Swim Lake

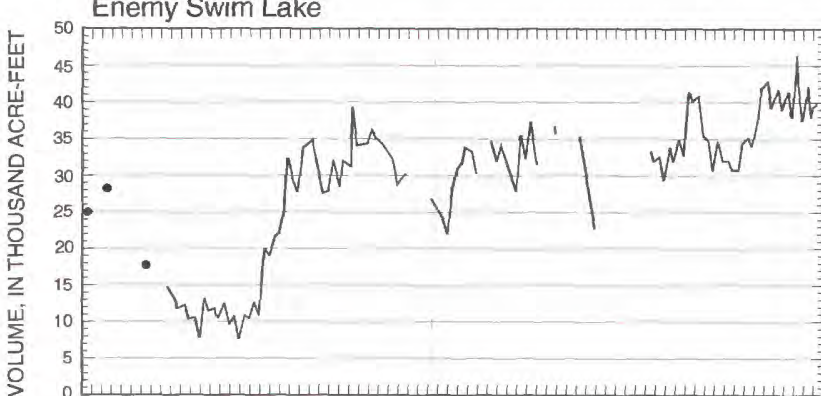

Hillebrands Lake
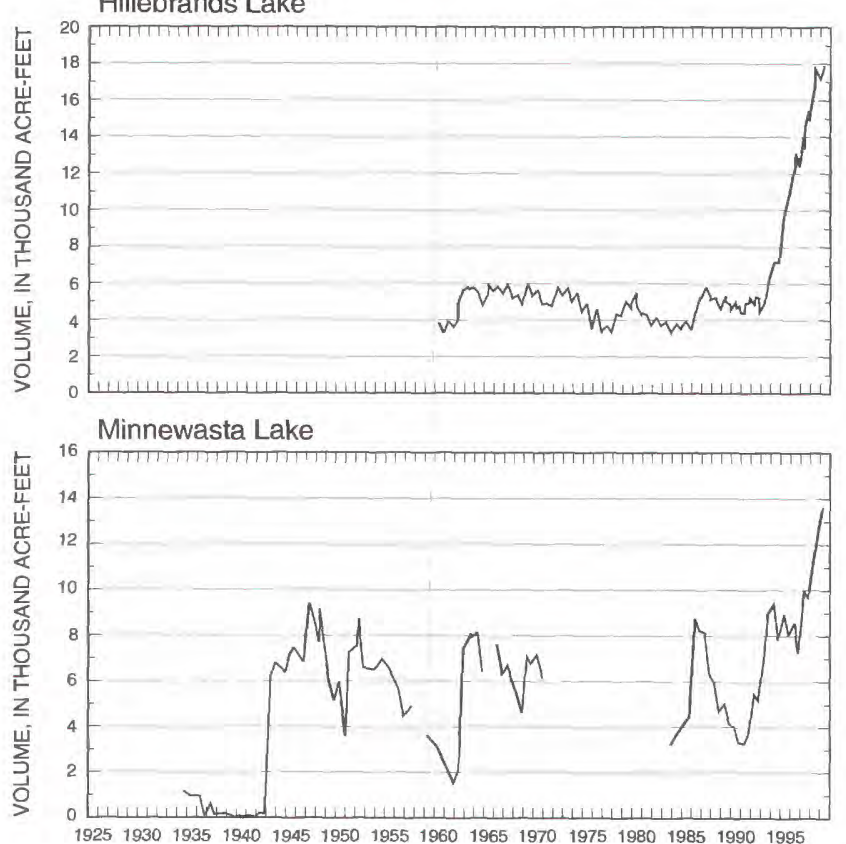

EXPLANATION

M. BLANK AREAS REPRESENT MISSING DATA GREATER

THAN 12 MONTHS DURATION

- INDIVIDUAL READING

Figure 5. Historic volume of individual lakes within the Waubay Lakes Chain.
Pickerel Lake

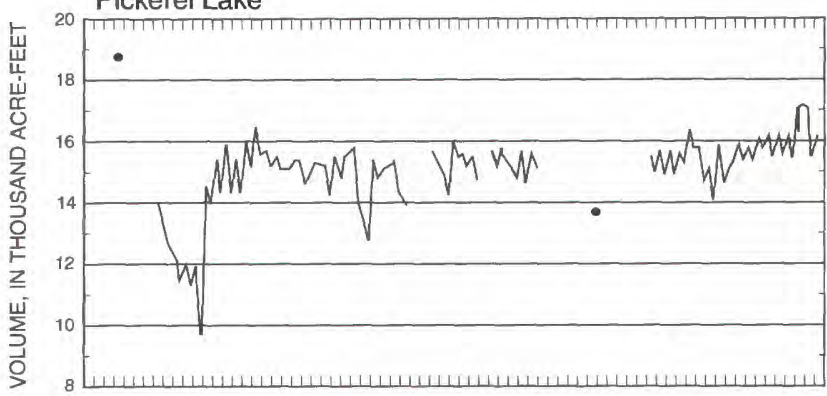

Rush Lake

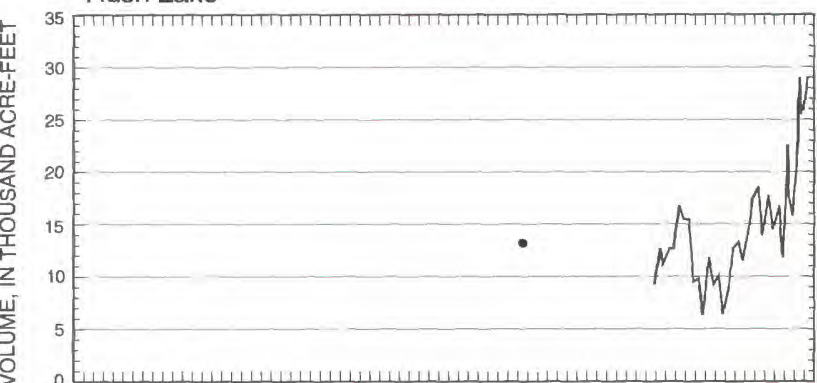

Spring Lake

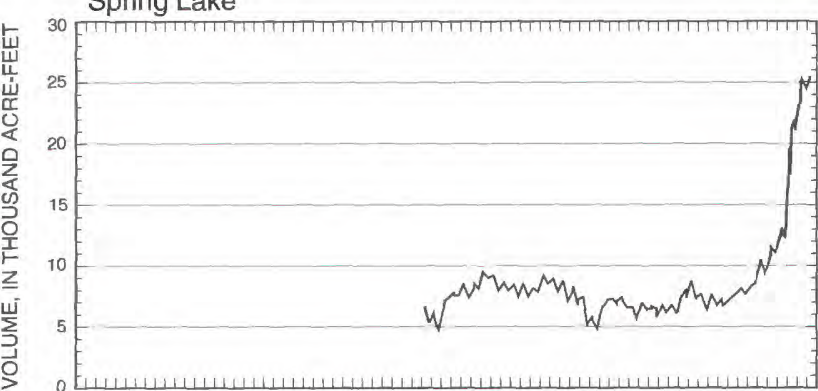

Swan Pond
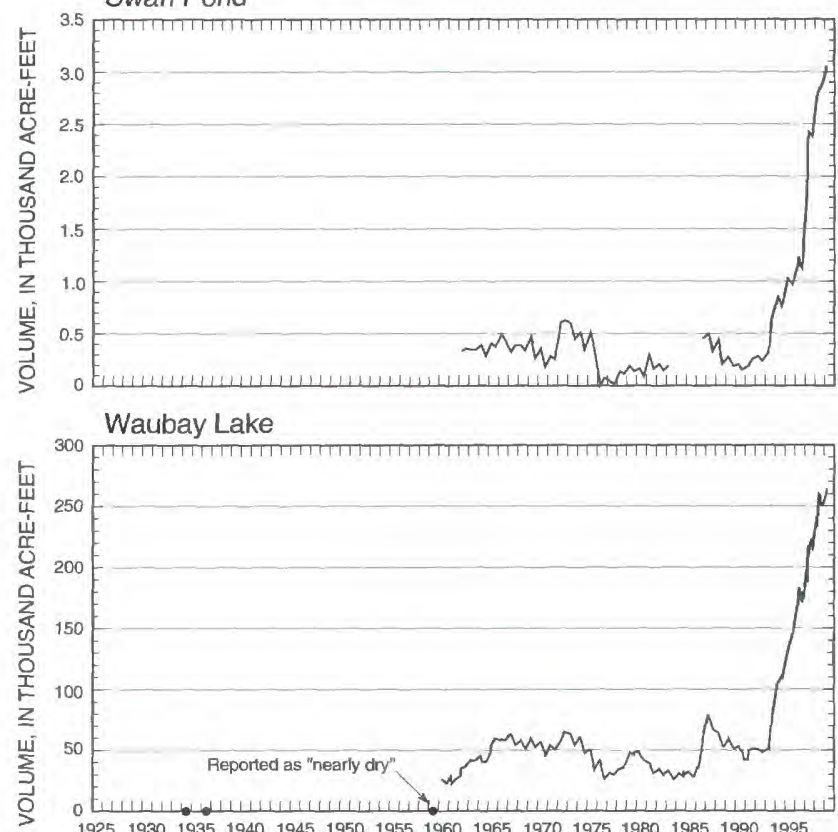
TOTAL AREA, 22,002 ACRES

May 1993

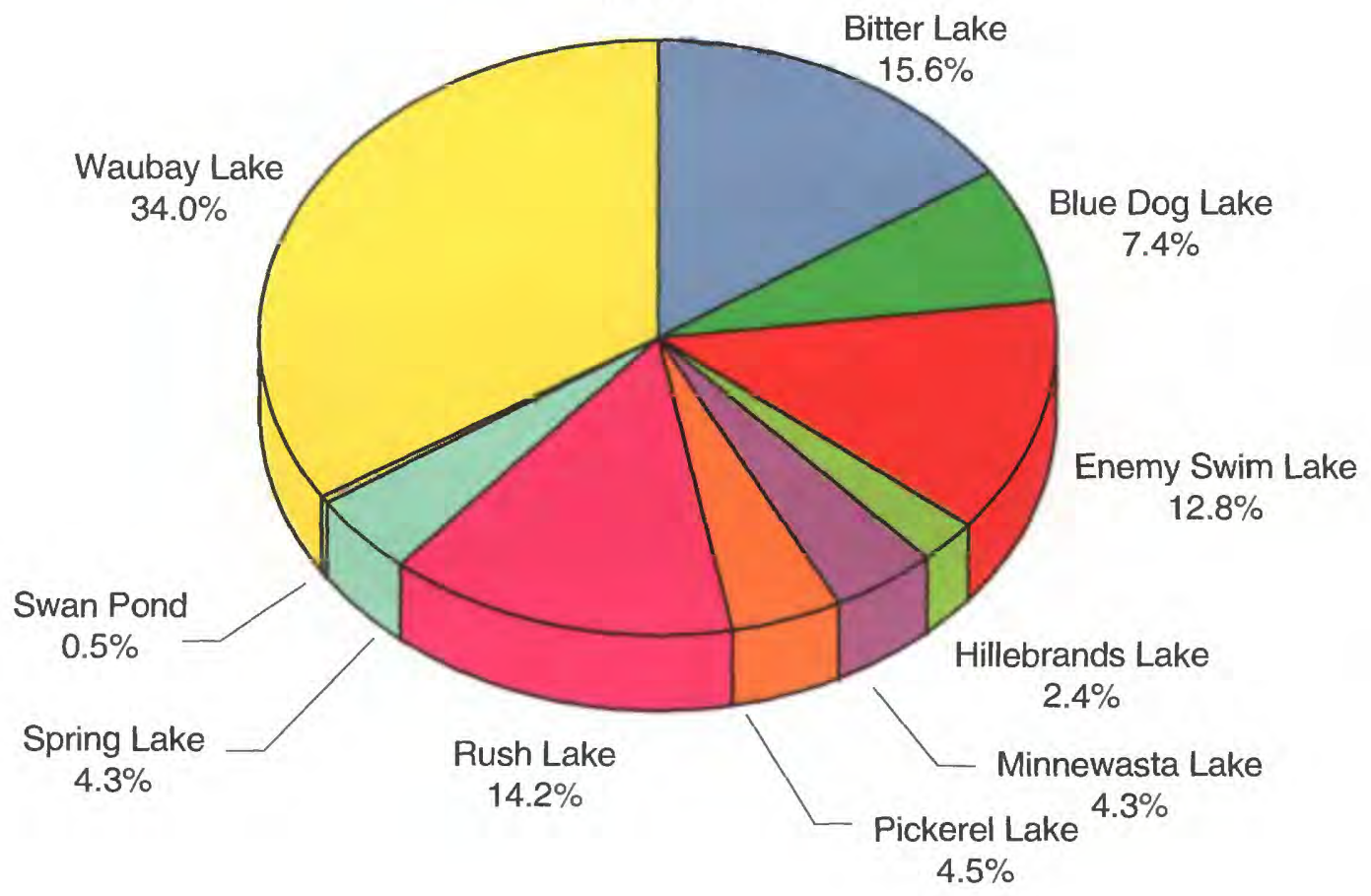

TOTAL AREA, 38,047 ACRES

April 1999

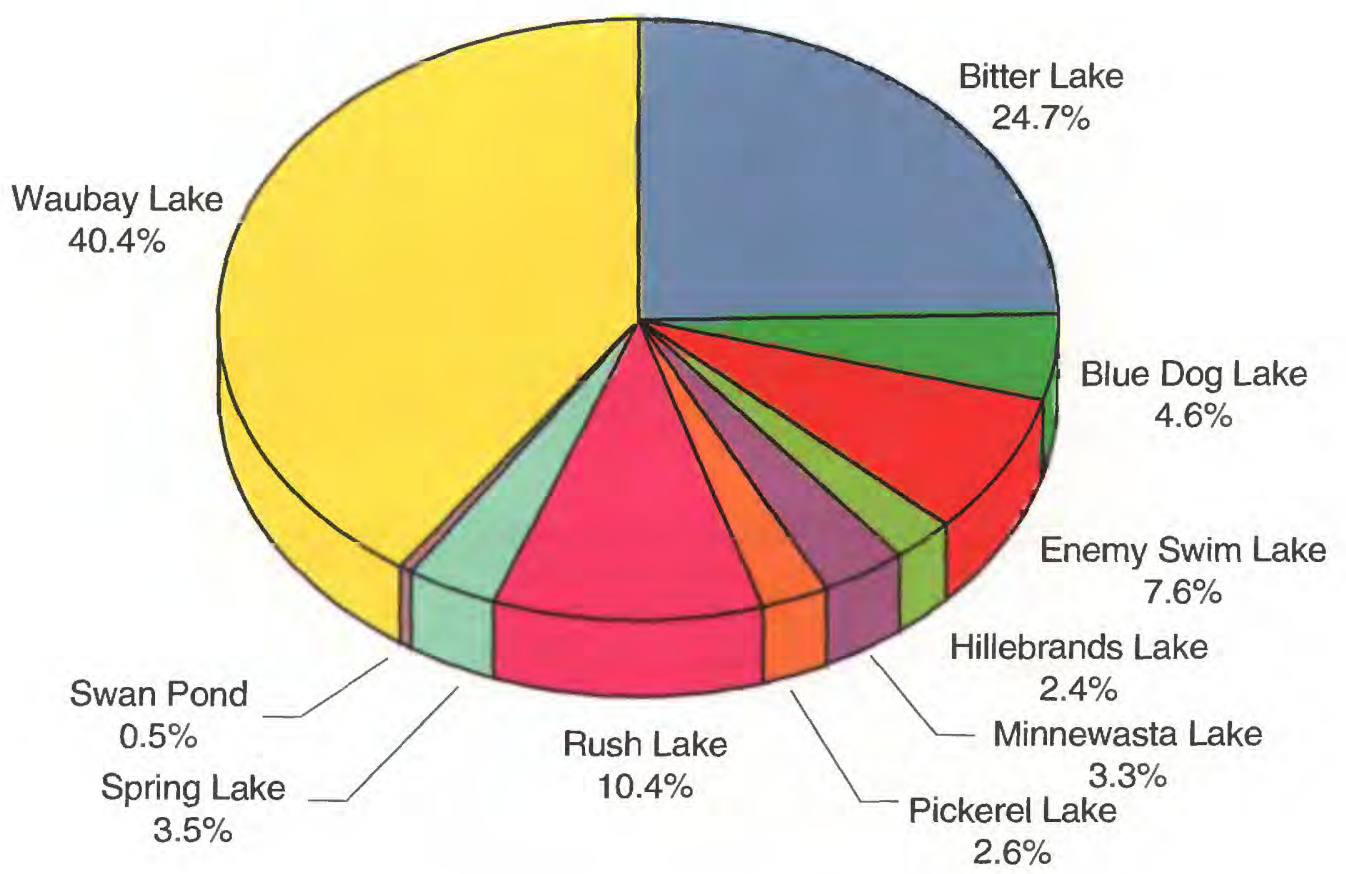

Figure 6. Areal distribution of the 10 major lakes of the Waubay Lakes Chain, May 1993 and April 1999. 
TOTAL VOLUME, 161,673 ACRE-FEET

May 1993

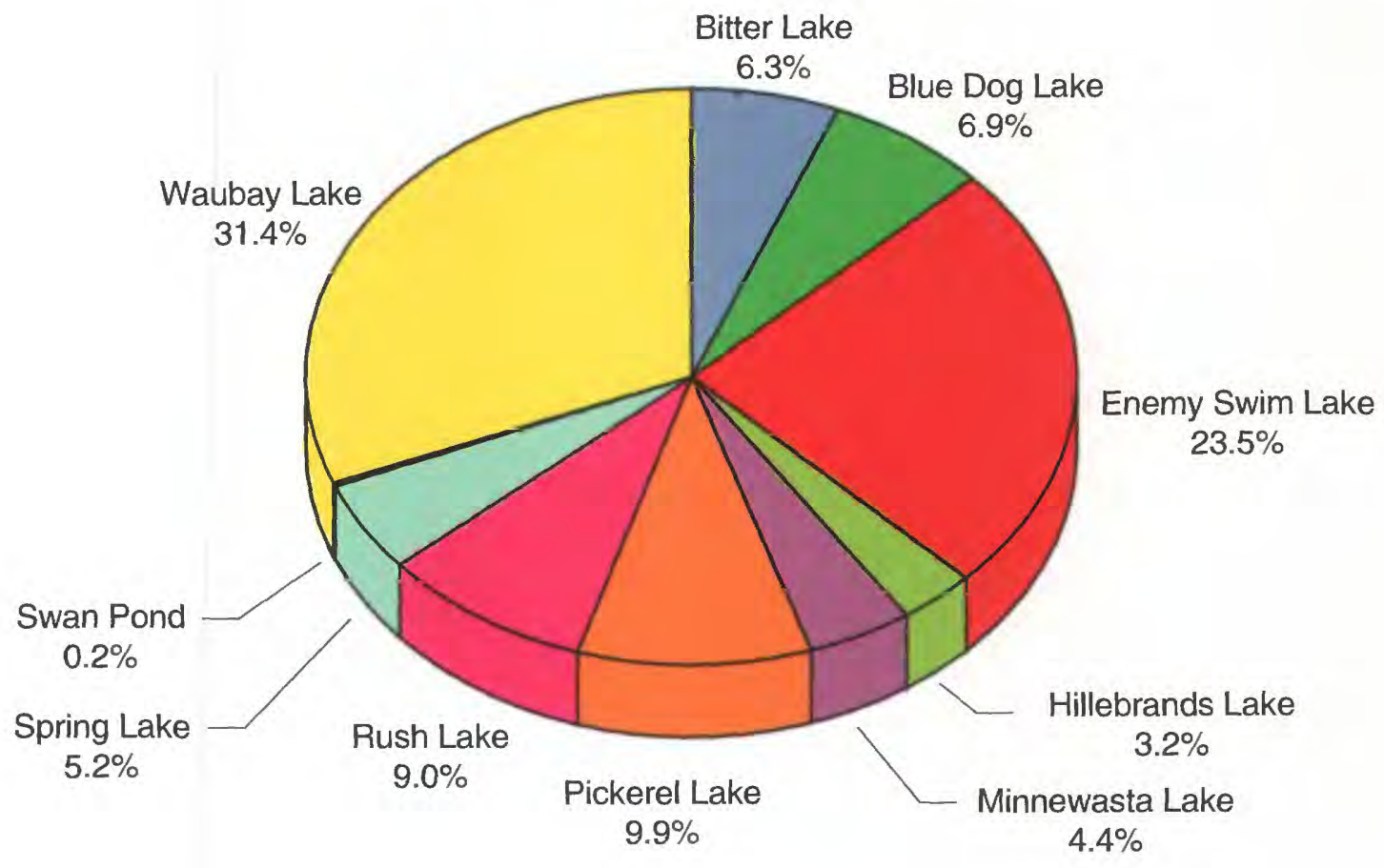

TOTAL VOLUME, 532,588 ACRE-FEET

April 1999

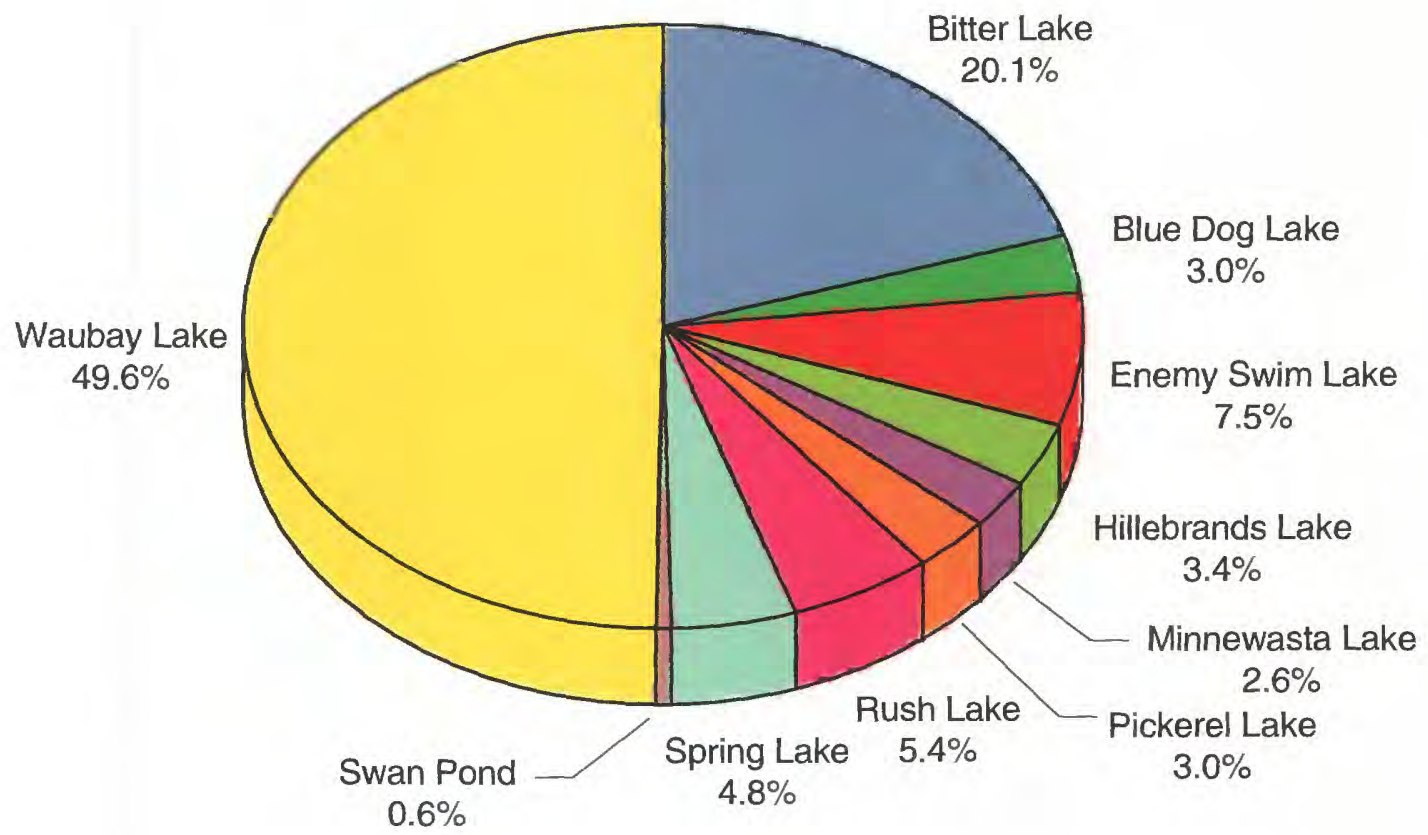

Figure 7. Volumetric distribution of the 10 major lakes of the Waubay Lakes Chain, May 1993 and April 1999. 


\section{Streams}

Only one major river, the Big Sioux River, is located near the study area (fig. 1). The river potentially could receive outflow from the study area if the lake levels of the Waubay Lakes Chain continue to rise. Preliminary global positioning system (GPS) surveys conducted for the study indicate that the lake levels of the Waubay Lakes Chain (with the exception of Enemy Swim and Pickerel Lakes) would have to rise above an elevation of $1,811.1 \mathrm{ft}$ to begin spilling from Bitter Lake to the Big Sioux River (fig. 2).

Smaller streams occur within the study area but usually only connect a few lakes or wetlands. All of the streams within the Waubay Lakes Chain Basin are intermittent and have no persistent base flow because of minimal ground-water discharge (Leap, 1988).

No streamflow-gaging stations are located within the study area. The closest station on the Big Sioux River - station 06479215, Big Sioux River near Florence, S. Dak.-is located southeast of the study area in Grant County (fig. 1). Daily discharge data have been collected at this station since June 1984. The daily discharge has ranged from zero on August 9-11, 1985; December 16, 1989, to March 5, 1990; and February 16-25, 1991, to 1,600 $\mathrm{ft}^{3} / \mathrm{s}$ on April 5, 1997. The annual mean discharge is $17.1 \mathrm{ft}^{3} / \mathrm{s}$ (U.S. Geological Survey, 1998).

Outflow from Enemy Swim and Pickerel Lakes (fig. 8) was measured by the USGS on November 16, 1998. Outflow from Enemy Swim Lake through Campbell Slough was $11.4 \mathrm{ft}^{3} / \mathrm{s}$, and outflow from Pickerel Lake was $10.9 \mathrm{ft}^{3} / \mathrm{s}$.

\section{Drainage Subbasins}

Drainage within the study area is not well developed, and the study area presently is a closed basin. As of late 1998, Waubay Lake was the terminal lake for all lakes within the study area except Bitter Lake. However, in the spring of 1999, Rush Lake rose above an elevation of $1,803.6 \mathrm{ft}$, and 9 of the 10 major lakes within the Waubay Lakes Chain began to spill into Bitter Lake, which then became the terminal lake. Above an elevation of $1,811.1 \mathrm{ft}$, all of the lakes of the Waubay Lakes Chain will spill through Bitter Lake (fig. 8) south to the Big Sioux River; above an elevation of $1,812.1 \mathrm{ft}$, the chain also will begin to spill east of Bitter Lake to the Big Sioux River.

Individual drainage areas of the 10 major lakes were determined by the USGS Earth Resources Observation System (EROS) Data Center using GIS software in conjunction with existing digital elevation models (DEM's) and other digital hydrologic data. The drainage areas for the lakes of the Waubay Lakes Chain are given in table 5. The individual drainage areas range from less than $0.5 \mathrm{mi}^{2}$ (Swan Pond) to less than $20 \mathrm{mi}^{2}$ (Hillebrands Lake, Minnewasta Lake, Rush Lake, and Spring Lake) to less than or about $50 \mathrm{mi}^{2}$ (Enemy Swim Lake and Pickerel Lake) to greater than $80 \mathrm{mi}^{2}$ (Bitter Lake, Blue Dog Lake, and Waubay Lake).

Table 5. Drainage areas of the 10 major lakes of the Waubay Lakes Chain

[Drainage areas determined by Earth Resources Observation System Data Center]

\begin{tabular}{lrrr}
\hline \multicolumn{1}{c}{ Lake } & $\begin{array}{c}\text { Area } \\
\text { (acres) }\end{array}$ & $\begin{array}{c}\text { Area } \\
\text { (square } \\
\text { miles) }\end{array}$ & $\begin{array}{r}\text { Percent of } \\
\text { total area }\end{array}$ \\
\hline Bitter Lake & 73,259 & 114.47 & 28.0 \\
Blue Dog Lake & 51,320 & 80.19 & 19.6 \\
Enemy Swim Lake & 32,276 & 50.43 & 12.3 \\
Hillebrands Lake & 6,440 & 10.06 & 2.5 \\
Minnewasta Lake & 3,518 & 5.50 & 1.3 \\
Pickerel Lake & 22,516 & 35.18 & 8.6 \\
Rush Lake & 11,423 & 17.85 & 4.4 \\
Spring Lake & 4,331 & 6.77 & 1.7 \\
Swan Pond & 286 & 0.45 & 0.1 \\
Waubay Lake & 56,698 & 88.59 & 21.6 \\
\cline { 2 - 4 } Total & 262,067 & 409.49 & 100.1 \\
\hline
\end{tabular}

${ }^{1}$ Total is greater than 100 percent because of rounding.

\section{Description of Lake Outlets}

The lake connections between the 10 major lakes of the Waubay Lakes Chain are shown in figure 9. The spill elevations and outlet locations are shown in figure 8. Most of the outlet information reported in the following discussion is based on information obtained from the SDDENR.

When Bitter Lake rises above an elevation of $1,811.1 \mathrm{ft}$, the Waubay Lakes Chain probably begins to spill from the southwest edge of Bitter Lake through Solomon Slough and then to the south out of Bitter Lake. The spill point out of Bitter Lake has been approximately located at latitude $45^{\circ} 11^{\prime} 1.9^{\prime \prime}$ and longitude $97^{\circ} 22^{\prime} 55.24^{\prime \prime}$ (North American datum of 1927) in sec. 24 (section 24), T. 120 N. (Township 120 North), R. 55 W. (Range 55 West). The water from the 


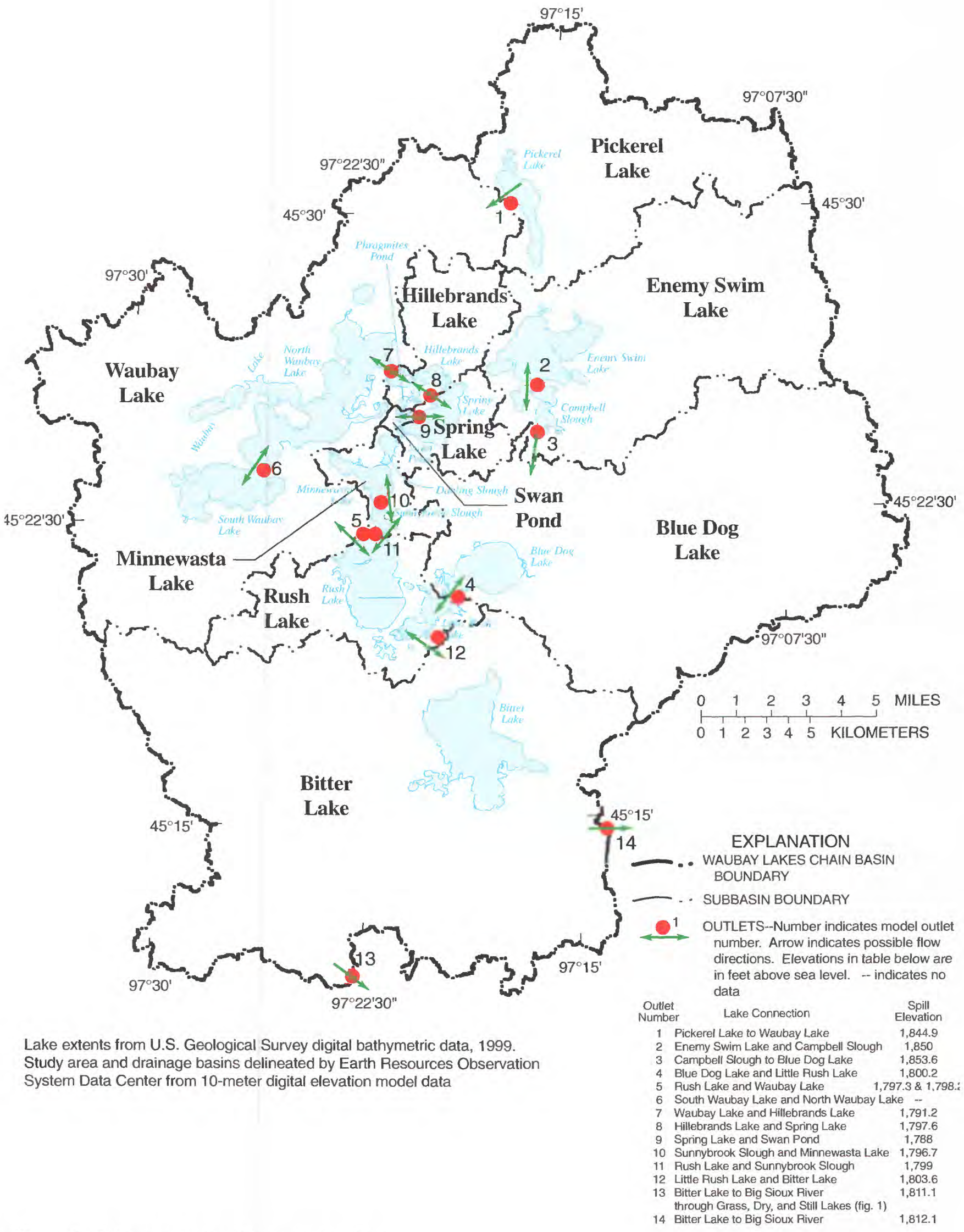

Figure 8. Subbasins for the Waubay Lakes Chain. 


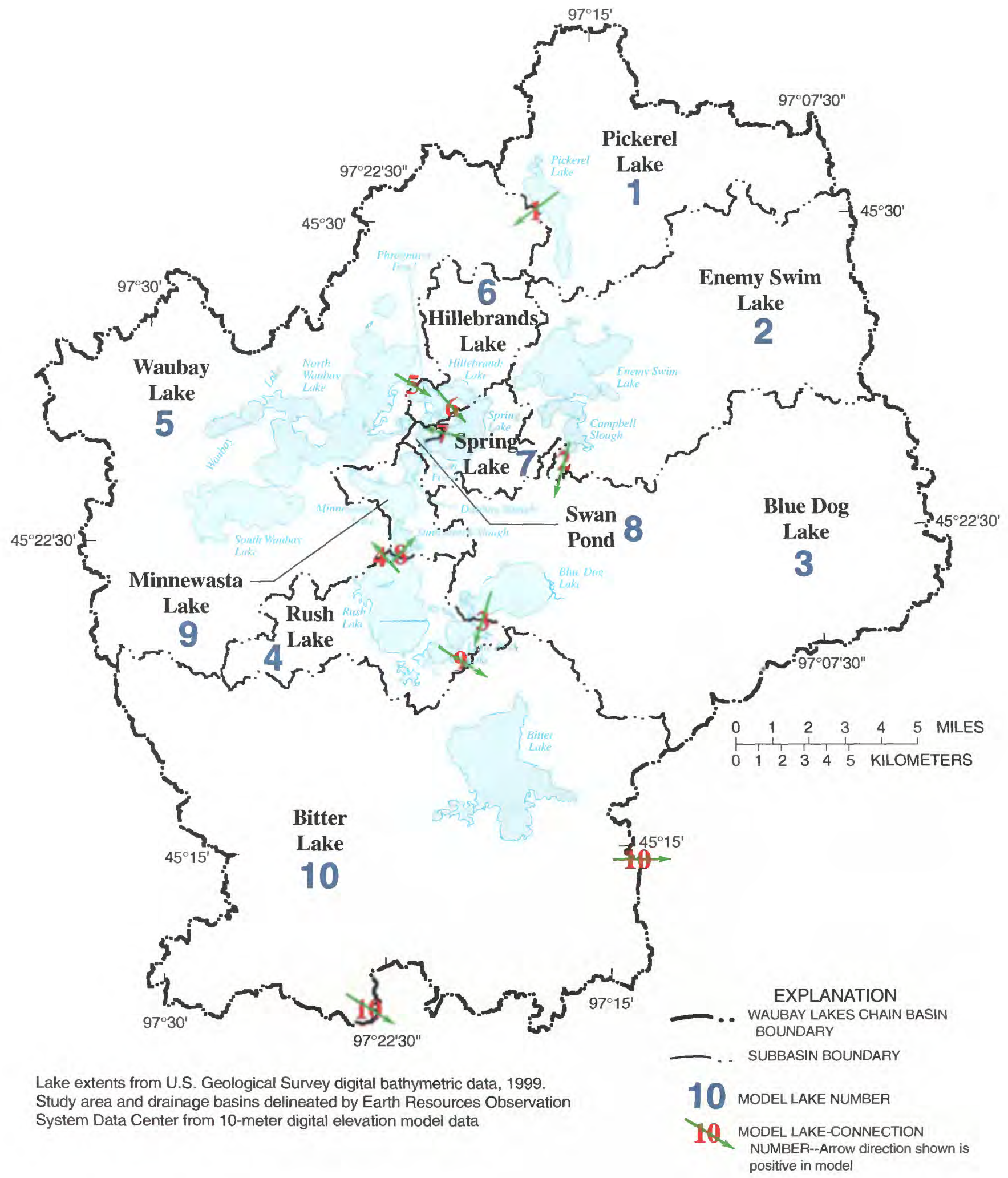

Figure 9. Water mass-balance model lake and lake-connection numbers for the Waubay Lakes Chain. 
Waubay Lakes Chain then flows south to Grass, Dry, and Still Lakes and then to the Big Sioux River. When Bitter Lake rises above an elevation of $1,812.1 \mathrm{ft}$, the Waubay Lakes Chain also probably begins to spill to the Big Sioux River from the southeast corner of Bitter Lake. This spill point is located about $2 \mathrm{mi}$ east of $447^{\text {th }}$ Ave. leading south out of Waubay and has been approximately located at latitude $45^{\circ} 14^{\prime} 39.7^{\prime \prime}$ and longitude $97^{\circ} 13^{\prime}$ 53.7' (North American datum of 1927) in sec. 24, T. 121 N., R. 53 W. From this spill point, the Big Sioux River is about $2 \mathrm{mi}$ to the east. The spill elevation used in the model for Bitter Lake and the Big Sioux River was $1,813 \mathrm{ft}$. The 1,811.1- and 1,812.1-ft elevations were not used because of the assumption that significant outflows from the Waubay Lakes Chain do not occur until Bitter Lake reaches an elevation of $1,813.0 \mathrm{ft}$. This assumption is based on the USACE outlet rating curve for the Bitter Lake to Big Sioux River connection.

From 1944 to 1980, the outlet from Blue Dog Lake was operated as a variable elevation control, and spill elevations to Little Rush Lake varied from 1,799.6 to $1,800.35 \mathrm{ft}$. In 1981, a new outlet was constructed at a set elevation of $1,800.2 \mathrm{ft}$. The structure consists of an 8-ft by $12-\mathrm{ft}$ box culvert across U.S. Highway 12 just to the north of Waubay. The outlet is located at the southwest edge of Blue Dog Lake in the southwest quarter of sec. 28, T. 122 N., R. 54 W. The spill elevation used in the model for Blue Dog and Rush Lakes was $1,799.8 \mathrm{ft}$. This elevation was selected because it was within the 1,799.6- to 1,800.35-ft range and produced the best match to historical lake levels.

Enemy Swim Lake connects to Campbell Slough at an elevation of $1,850 \mathrm{ft}$ via a large box culvert at a road crossing at the south-central edge of the lake. Before the early 1920's, the original outlet to Blue Dog Lake had a spill elevation of about $1,857 \mathrm{ft}$. In the early 1920's, the outlet was lowered to an elevation of 1,853.6 ft. The present outlet for Enemy Swim Lake and Campbell Slough to Blue Dog Lake also is at a spill elevation of $1,853.6 \mathrm{ft}$. The present outlet was built in 1973 and consists of a 15-ft-wide concrete weir. The outlet is located at the south edge of Campbell Slough in the northeast quarter of $\sec 27$, T. 123 N., R. $53 \mathrm{~W}$. The spill elevation used in the model for Enemy Swim and Blue Dog Lakes was 1,853.6 ft.

Hillebrands Lake connects to Waubay Lake at an elevation of $1,791.2 \mathrm{ft}$ via overflow over a road that separates the west edge of Hillebrands Lake from Waubay Lake. The overflow is located in the middle of sec. 30, T. 123 N., R. 54 W. Phragmites Pond als? connects to Hillebrands Lake at the south-central edge of the lake. The spill elevation used in the model for Hillebrands and Waubay Lakes was 1,791.2 ft.

Minnewasta Lake connects to Sunnybrook Slough at an elevation of 1,796.7 ft via a bridge on a county road at the south edge of Minnewasta Lake. Minnewasta Lake and Sunnybrook Slough connert to Rush Lake in the northeast quarter of sec. 24, T. 122 N., R. 55 W. Based on analysis of lake-level records and aerial photos, the spill elevation between Sunnybrook Slough and Rush Lake is estimated to be about $1,799.0 \mathrm{ft}$. This spill elevation differs from the SDDENR data, which indicate the two lakes connect via two culverts through a farm crossing at a spill elevation of 1,796.7 ft. Minnewasta Lake connects to Dahling Slough, which is located to the north of Minnewasta Lake, at an elevation of about $1,803 \mathrm{ft}$. The spill elevation used in the model for Minnewasta and Rush Lakes was 1,799.0 ft.

The original outlet from Pickerel Lake to Waubay Lake was built because of high lake levels in 1928. The outlet was constructed to spill at an elevation of $1,844.9 \mathrm{ft}$. In 1992, a new outlet, consisting of a 53-ft-wide concrete weir, was constructed by th: South Dakota Department of Game, Fish and Par's at the same elevation. The outlet is located at the westcentral edge of Pickerel Lake in Pickerel Lake State Park in the southwest quarter of sec. 22, T. 124 N., R. $53 \mathrm{~W}$. The spill elevation used in the model for Pickerel and Waubay Lakes was 1,844.9 ft.

In 1946-48, the outlets from Rush Lake to Waubay (South) Lake were built by the South Dakota Department of Transportation. The two outlets consisted of two trapezoidal-shaped concrete fords-one that had a 40-ft bottom width, a 6:1 side slope, ard a 1,797.3-ft spill elevation, and another that had a $2.7-\mathrm{ft}$ bottom width, a 4:1 side slope, and a 1,798.2-ft spill elevation. These fords are located at the northwert edge of Rush Lake in the northwest quarter of sec. 24, T. 122 N., R. 55 W. To better simulate historic lakelevel data, the spill elevation used in the model for Rush and Waubay Lakes was 1,798.7 ft. Outflow from Rush Lake to Bitter Lake is through Little Rush Lake by overtopping a farm-crossing embankment. The spill elevation between Rush and Bitter Lakes is $1,803.6 \mathrm{ft}$. The farm crossing is located south of Little Rush Lake and west of Waubay in the northeast quarter of sec. 5, T. 121 N., R. 54 W. If this crossing is removed or 
washed out, culverts across an east-west county road immediately south of a railroad embankment would cause Rush Lake to spill at an elevation of $1,798.7 \mathrm{ft}$. The spill elevation used in the model for Rush and Bitter Lakes was $1,803.6 \mathrm{ft}$.

Spring Lake connects to Hillebrands Lake at an elevation of $1,797.6 \mathrm{ft}$ via overflow over a road that separates Spring and Hillebrands Lakes just west of the Waubay National Wildlife Refuge. The overflow is located in the middle of sec. 32, T. 123 N., R. 54 W. Before the high lake levels of the 1990's, Spring Lake also was connected to Hillebrands Lake via a culvert under the road to the Refuge at the extreme northeast edge of Spring Lake and the extreme southeast edge of Hillebrands Lake. The road to the Refuge recently has been raised and the culvert and connection probably no longer exist. The spill elevation used in the model for Hillebrands and Spring Lakes was 1,797.6 ft.

Swan Pond connects to Spring Lake at an elevation of $1,788 \mathrm{ft}$ via land overflow. The overflow is located in the extreme northwest corner of sec. 5 and the extreme northeast corner of sec. $6, \mathrm{~T} .122 \mathrm{~N}$., R. 54 W. The spill elevation used in the model for Spring Lake and Swan Pond was 1,788.0 ft.

Waubay Lake spills to Bitter Lake via Rush and Little Rush Lakes at an elevation of 1,803.6 ft. The connection to Rush Lake was discussed previously in the paragraph on Rush Lake.

As lake levels rise above the spill elevations between the lakes, water may flow either direction while lake levels equalize. As of April 1999, Swan Pond and Blue Dog, Hillebrands, Minnewasta, Rush, Spring, and Waubay Lakes were joined and had begun to spill into Bitter Lake. Therefore, all nine northernmost lakes drain to Bitter Lake.

\section{Geology and Ground Water}

The study area is overlain primarily by Pleistocene glacial deposits. During the Pleistocene Epoch in South Dakota, the area east and north of the Missouri River was almost completely covered by glaciers. The glaciers partially filled major valleys, forced the cutting of new valleys, formed massive end moraines, and left glacial deposits throughout eastern South Dakota. The glacial deposits can be categorized into till or outwash. Till was deposited directly by and underneath glaciers without any subsequent reworking by the glacier's water. Till is a heterogeneous mixture of clay, silt, sand, gravel, and boulders of various sizes and shapes (Gary and others, 1972) and consists primarily of clayey or silty sand or gravelly silt or clay. Outwash is sand and gravel deposited by flowing glacial meltwater. The glacial deposits may be covered by nonglacial deposits of alluvium along streams, and locally, the deposits may be covered by loess. Many of the glacial deposits within the study area are stagnation moraines (Gries, 1996), which were defosited near the end of the glacial period when the ice stopped moving and melted. This resulted in a rugged, poorly drained land surface full of small lakes, potholes, and sloughs. Glaciation also resulted in major changes to the surface drainage. The drainage in eastern Soutl Dakota is predominantly southward because of the glaciation (Flint, 1955).

The bedrock units directly underlying the glacial deposits and nonglacial loess and stream deposits in Day County are Cretaceous in age and include the Dakota Formation, Graneros Shale, Greenhorn Limestone, Carlile Shale, Niobrara Formation, and Pierre Shale. These units can have a total thickness of as much as $1,000 \mathrm{ft}$ (Leap, 1988). Outcro'ss of Pierre Shale have been noted in Day County (Rothrock, 1935).

Some of the lakes of the Waubay Lakes Chain are hydraulically connected to underlying aquifers (Leap, 1988). However, ground-water flow between lakes of the chain is minimal, based on the interpretation that ground-water flow between acuifers that underlie the lakes is minimal (Derric Iles, South Dakota Geological Survey, oral commun., 1999). Outflow from the Waubay Lakes Chair Basin to surrounding basins via these aquifers also is minimal. Although Leap (1988) noted extensive subsurface hydraulic connections between many of the lakes in the chain, recent reinterpretation of drill-lo data by the SDGS indicates that many of the surficial deposits may have been incorrectly mapped (Derric Isles, South Dakota Geological Survey, oral commun., 1999). The USGS water mass-balance model, which will be discussed in more detail later, substantiates this reinterpretation. Additional data would be needed to substantiate the existence of some of the subsurface connections noted by Leap (1988) and to substantiate the degree of those connections.

\section{Approach}

The approach used in this study is similar to the approach used by Wiche and Vecchia (1996) for a Devils Lake, N. Dak. study. In the Devils Lake study, 
a statistical water mass-balance model was developed to generate quarterly (winter, spring, summer, and fall) lake volumes or levels from quarterly precipitation, evaporation, and inflow. A multivariate time-series model also was developed to generate hypothetical future sequences of quarterly precipitation, evaporation, and inflow. The two Devils Lake models were used conjunctively to generate quarterly hypothetical lake volumes or levels, and 2,000 50-year traces were generated to obtain probabilities of future lake levels. The Devils Lake study was similar to studies by Bowles and James (1986) and James and others (1977) for the Great Salt Lake.

The length of the historic record used in this study is similar to that used in the Devils Lake study (1963-98 for the Waubay Lakes Chain and 1950-93 for Devils Lake), but semiannual data are used instead of quarterly data. Also, few data were available for inflow to individual lakes of the Waubay Lakes Chain, but extensive data were available for inflow to individual lakes for the Devils Lake study. In addition, historic lake-level data for the Waubay Lakes Chain usually consist of less than three observed lake levels per year for any given lake in the chain, but daily lakelevel data are available for Devils Lake.

\section{WATER MASS-BALANCE MODEL}

The water mass-balance model (available at the USGS Subdistrict office in Huron, S. Dak.) was developed to simulate semiannual lake volumes of the 10 major lakes of the Waubay Lakes Chain using precipitation, evaporation, total inflow to the system, and starting lake levels as input. The input either is read from a file for each time step of the simulation or is generated by the stochastic time-series model discussed in a later section. The water mass-balance model simulates the volumes by accounting for all water entering and leaving each lake. This is done by developing volume equations for each lake (eq. 1). The lake volume at the end of a time step was computed as (1) the lake volume at the beginning of the time step, (2) plus precipitation falling directly on the lake, (3) minus evaporation directly from the lake, (4) plus inflow from surface runoff, (5) plus or minus flow between lakes. The equations for computing the volume of each lake are given in table 6 .

$$
V_{1}=V_{0}+p-e+I \pm r d w
$$

The first step in development of the water massbalance model was to compile historic data to construct and verify the model. The historic data needed included lake-level, precipitation, and evaporation data.

The second step was to analyze the historic data to gain an understanding of the Waubay Lakes Chain. Then, model development was initiated to estimste lake volumes for the 10 major lakes within the cr ain using precipitation, evaporation, total inflow to the system, and starting lake levels as input. Total inflow to the system was apportioned to each of the 10 lakes using a regression of changes in individual lake volume versus net atmospheric gain and total inflow. Next, flow between lakes was incorporated into the model using an iterative process to balance the level of each lake and taking into account flow from connectirg lakes. The iterative process was not needed for the Pickerel Lake to Waubay Lake, Enemy Swim Lake to Blue Dog Lake, and Bitter Lake to Big Sioux River connections because spill can occur only from the upstream lake.

The model was verified by simulating water year 1963-98 data. The 1963 lake levels were used as starting lake levels, and the results were compared to historic data. The model uses numbering systems for lakes and lake connections as shown in figure 9.

\section{Data Set Development}

Historic lake-level data were compiled from all available sources, and water years 1963-98 were selected for model development. Those years were chosen because of the availability of lake-level data. Missing data were generated using regression as needed, and a semiannual lake-level record was constructed using two semiannual periods, winter and summer. The winter period is from October 1 (tr' a beginning of the water year) through April 30, ard the summer period is from May 1 through September 30 (the end of the water year). A semiannual time step was considered the smallest time step that should be used given the data available.

Precipitation data used to develop the model were compiled from data collected at the Waubay National Wildlife Refuge during 1963-98, and evaporation data were estimated by $\mathrm{Al}$ Bender, State Climatologist. Because the model operates on lake volumes rather than lake levels, bathymetric data were used to convert the lake-level data to area and vclume data. The lake-level, precipitation, and evaporat ion data then were used to compute total inflow to the Waubay Lakes Chain. 
Table 6. Water mass-balance model equations used to compute lake volumes of the 10 major lakes of the l'/aubay Lakes Chain

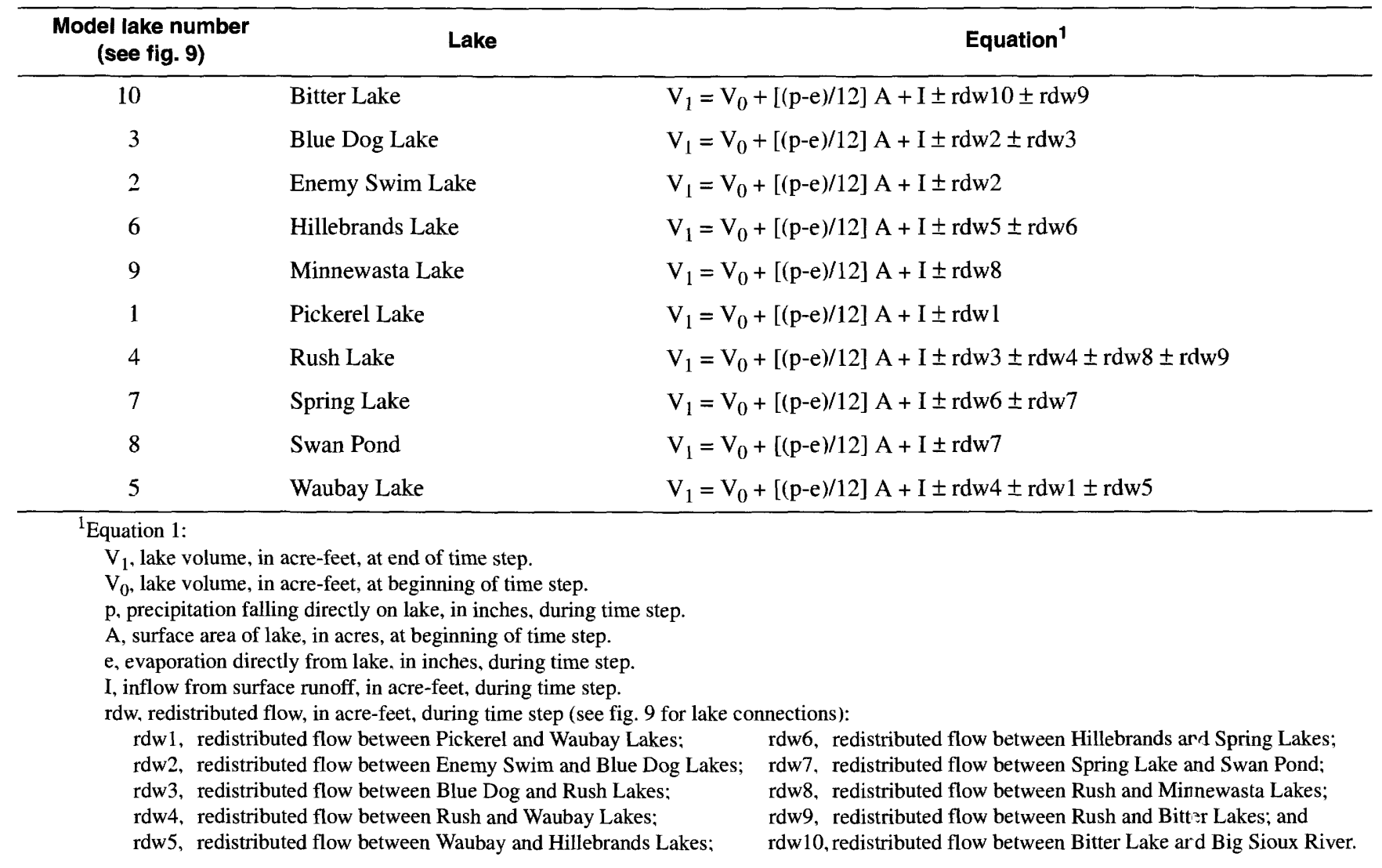

\section{Lake Levels}

Historic lake-level data for the 10 major lakes of the Waubay Lakes Chain are shown in figure 10. The lowest and highest recorded lake levels and the sources of these data are given in table 2. Although table 2 includes sources other than the SDDENR and Waubay National Wildlife Refuge, most data were obtained directly or indirectly from those two sources. Historic lake-level data commonly consist of two measurements per year, one near the spring lake-level peak (about May 1) and the other near the end of the summer lakelevel decline (about October 1). The historic lake-level data are given in table B1 of the Supplemental Information section. The sources of the data and the known and estimated datum corrections also are given.

The length of record ranges from 18 years for Bitter and Rush Lakes to more than 50 years for Blue Dog, Enemy Swim, Minnewasta, and Pickerel Lakes (table 2). The length of record for each of the remaining four lakes is about 40 years. The period of record ranges from 1925 to 1999. Except for Bitter and
Rush Lakes, data are available for much of 1960-99. Bitter and Rush Lakes generally have data available for 1983-99.

Analysis of the available record for low lake levels indicates Bitter Lake was dry in 1983 and nearly dry (less than $4 \mathrm{ft}$ deep) many times during 1984-93.

Blue Dog Lake was nearly dry (less than or equal to $5 \mathrm{ft}$ deep) from 1933 to 1936 . The lowest lake level for Enemy Swim Lake occurred in October 1940 when the lake was about $14 \mathrm{ft}$ deep (at deepest point). The lowest lake levels for Hillebrands Lake occurred during 1960-62, 1975-77, and 1981-85 when th a lake was about $16 \mathrm{ft}$ deep. Minnewasta Lake was dry in November 1939 and nearly dry (less than $5.5 \mathrm{ft}$ deep) from 1934 to 1942. Except for 1933-36 and 1953, Pickerel Lake has been consistently nea* its spill elevation of 1,844.9 ft (fig. 8). Rush and Spring Lakes have had no extreme low lake levels for their periods of record, although aerial photos indicate Push Lake has been dry in the past. Swan Pond was nearly dry in May 1976, and Waubay Lake was dry in 1934 and 1936 and nearly dry in 1959. 
Bitter Lake

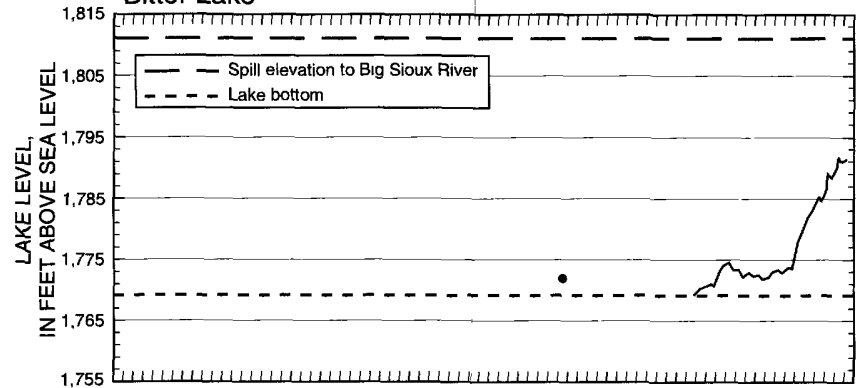

Blue Dog Lake

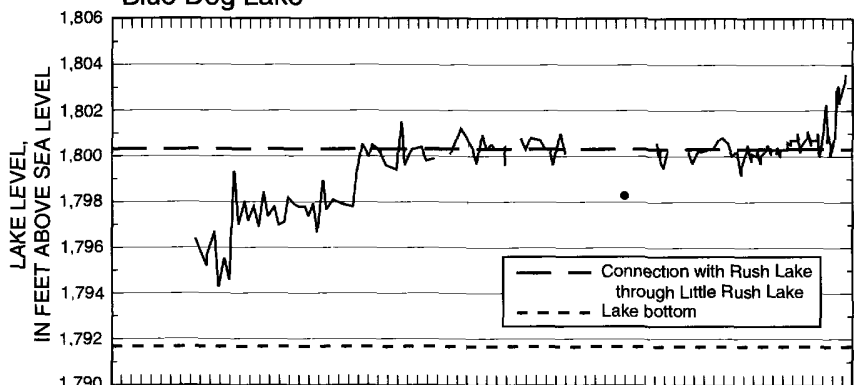

Enemy Swim Lake

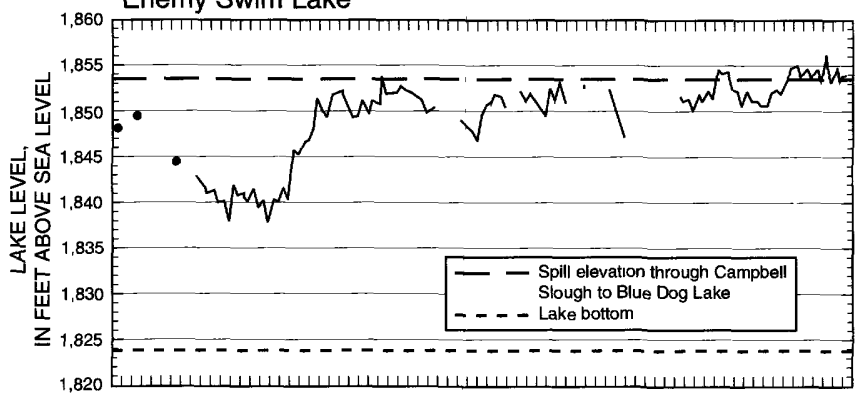

Hillebrands Lake

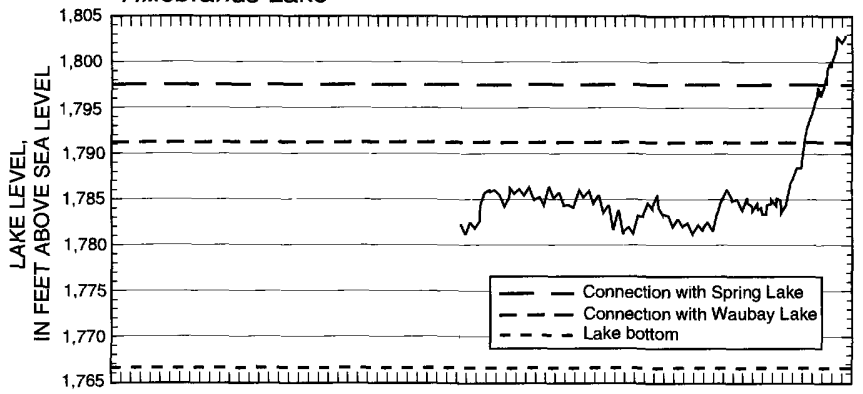

Minnewasta Lake

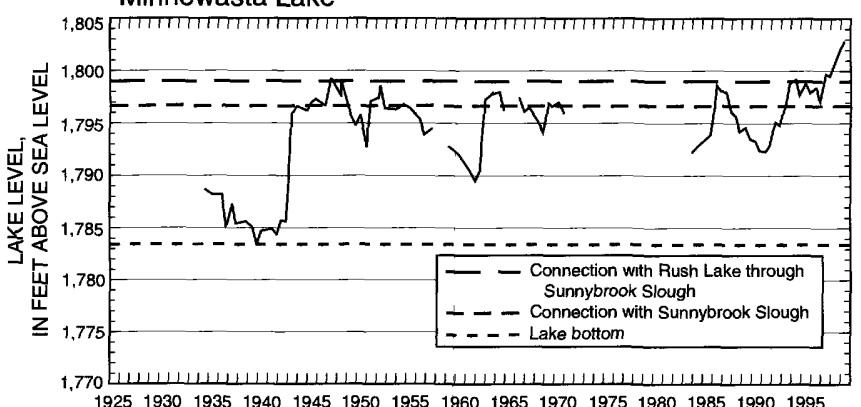

Pickerel Lake

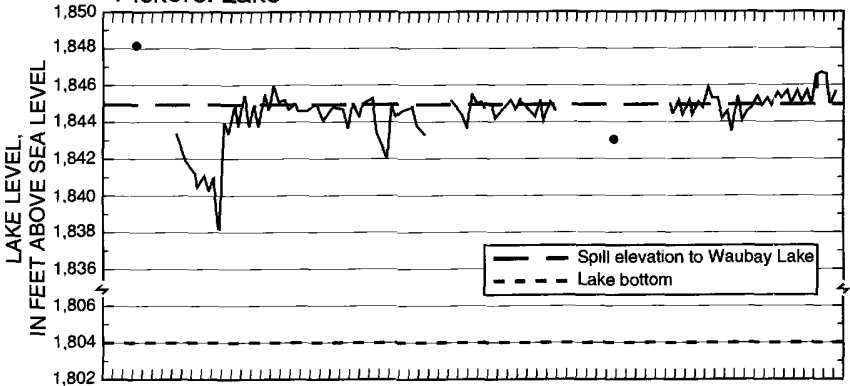

Rush Lake

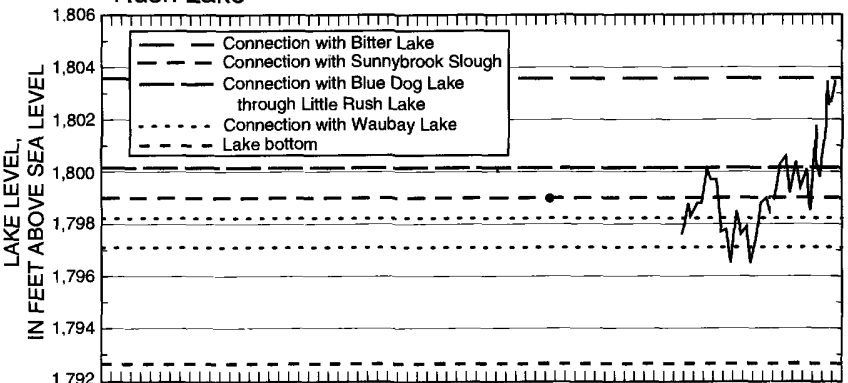

Spring Lake

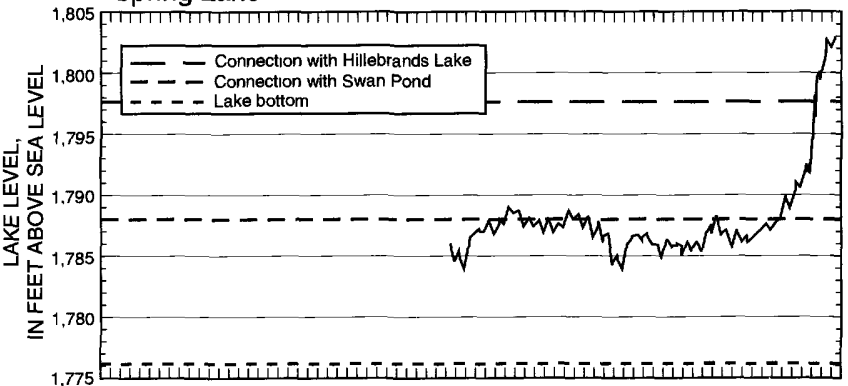

Swan Pond

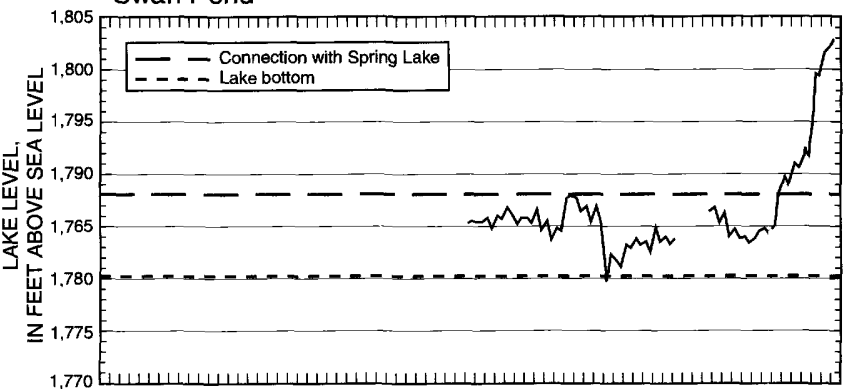

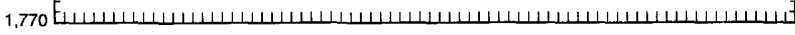

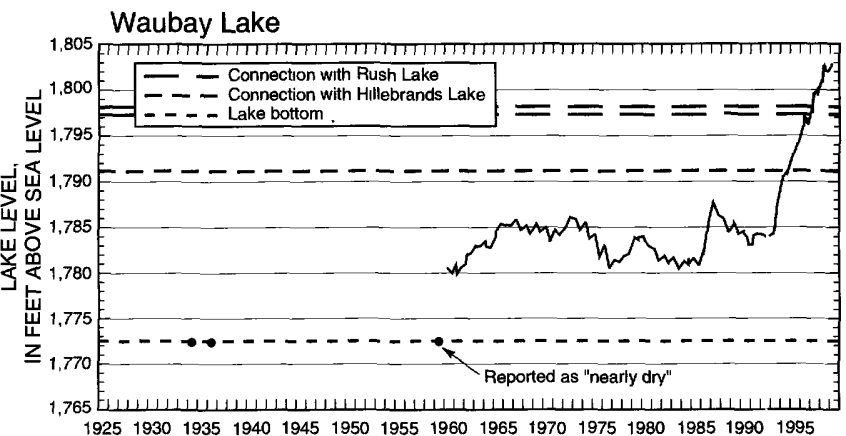

EXPLANATION

$M$ BLANK AREAS REPRESENT MISSING DATA GREATER

THAN 12 MONTHS DURATION

- INDIVIDUAL READING

Figure 10. Historic lake levels of individual lakes within the Waubay Lakes Chain. 
Analysis of the available record for high lake levels indicates Bitter Lake rose about $18 \mathrm{ft}$ from late 1993 to early 1999. This rise in Bitter Lake was due primarily to runoff from within its basin, based on the fact that the first historic record of Little Rush Lake spilling to Bitter Lake occurred in April 1999. Blue Dog Lake started receiving backwater from Rush Lake in April 1997 and presently (April 1999) is about $3.5 \mathrm{ft}$ above its spill elevation of 1,800.2 ft (fig. 8). Available lake-level data indicate Enemy Swim Lake spilled through Campbell Slough from May 1986 to April 1987 and from May 1993 to April 1999. The highest lake level was about $2.5 \mathrm{ft}$ above the spill elevation of $1,853.6 \mathrm{ft}$ (fig. 8). Hillebrands Lake rose about $18 \mathrm{ft}$ from May 1993 to April 1999 and started receiving backwater from Waubay Lake during May 1995.

Minnewasta Lake rose more than $10 \mathrm{ft}$ from November 1942 to June 1943 and probably joined with Rush Lake in early 1998. Available lake-level data indicate Pickerel Lake generally remains above or within a foot below its spill elevation of $1,844.9 \mathrm{ft}$. During the drought of the 1930's, the lake level was below its spill elevation from 1932 to 1937 . The highest level recorded (1928) for Pickerel Lake was about $3.3 \mathrm{ft}$ above the outlet elevation. Rush Lake rose more than
$4 \mathrm{ft}$ from May 1993 to April 1999. Spring Lake rose about $11 \mathrm{ft}$ from May 1996 to April 1999 after receiving water from Hillebrands Lake, and Swan Pond rose about $18 \mathrm{ft}$ from May 1993 to April 1999 after receiving water from Spring Lake. Waubay Lake rose more than $18 \mathrm{ft}$ from May 1993 to April 1999.

Water years 1961-98 initially were selected for model development. However, the existing data for 1962 appear anomalous with what would appear reasonable for that year. May-to-September precipitation versus total inflow to the Waubay Lakes Chain for 1961-98 (fig. 11) indicate 1962 is an outlier. Although the highest precipitation occurred during 1962, calculated total inflow was negative. Therefore, water years 1963-98 were selected for the water mass-balance simulations. Although figure 11 shows oth 9 inflows between zero and -4,000 acre- $\mathrm{ft}$, these values should not be treated as outliers. Small negative inflows result from inaccuracies in the estimated precipitation and evaporation and are more likely to occur in dry years.

Hillebrands, Spring, and Waubay Lakes had complete records of semiannual lake levels for 1960-99 (table 2). The remaining lakes had only partial records for those years. Therefore, a regression analysis was used to generate the missing lake-level data. Lake-

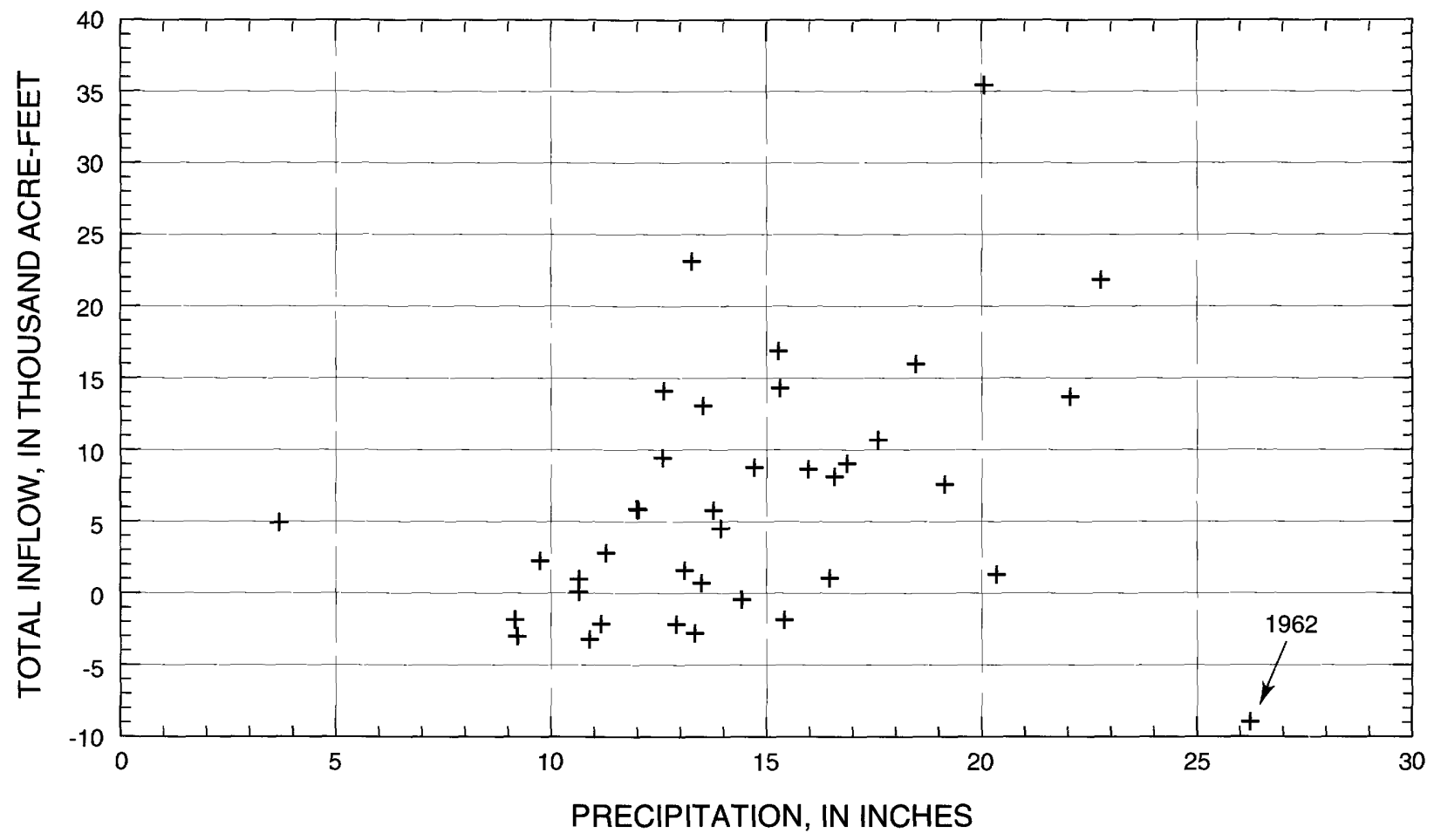

Figure 11. Precipitation versus total inflow for the Waubay Lakes Chain, May-September 1961-98. 
level data for lakes that had only partial records were compared to data for lakes that had complete records. Aerial photos for 1939, 1952, 1958, 1970, 1977 (orthophoto), 1982, 1984, and 1991 were available for some of the missing years and were used to supplement the existing lake levels and the regression analysis. The regression analysis is described in detail in procedure $\mathrm{C} 1$ of the Supplemental Information section. The regression was used to extend lake-level data for Bitter and Rush Lakes back to 1960, and to estimate lake-level values between data points for the remaining lakes. Estimated and historic lake levels are shown in figure 12, and estimated lake areas and volumes for the Waubay Lakes Chain are shown in figures 13 and 14. Estimated and historic lake areas and volumes for each of the 10 major lakes are shown in section D (fig. D1) of the Supplemental Information section. The complete data set for semiannual estimated lake levels for the Waubay Lakes Chain is given in table B2 of the Supplemental Information section. The estimated data closely resemble historic lake levels, areas, and volumes. Because only two data points per year are used to represent the lake level, area, and volume of each lake as model input, the estimated data must represent the trend occurring in the time step rather than extremes of short duration. This is especially important regarding the last few years (1996-99), when measurements were sometimes taken as frequently as several per week.

\section{Precipitation}

Precipitation falling on the study area is assumed to have been spatially uniform. Locally, precipitation is recorded at the Webster and the Waubay National Wildlife Refuge Headquarters stations. Because the Waubay National Wildlife Refuge Headquarters station is more centrally located within the study area, precipitation data from that station were used to represent precipitation over the entire study area. Precipitation data for the period of record at the Waubay National Wildlife Refuge Headquarters station were obtained from the National Climatic Data Center (1998) and from the U.S. National Oceanic and Atmospheric Administration (1998-99). These data are shown in figure 15 and given in table B3 of the Supplemental Information section. The May 1985 value was estimated by substituting a value from the Webster station. Water year precipitation data, were divided into two seasonal periods for the model. The winter period is from October 1 through April 30, and the summer period is from May 1 through September 30.

Analysis of the annual precipitation totals indicates a wetter-than-normal trend beginning in 19?1. The average annual precipitation for water years 1961-90 is 20.4 in., and the average annual precioitation for water years 1991-98 is 23.5 in. Although the annual average for 1991-98 is more than 3 in. greater than the annual average for 1961-90, a two-sample t-test did not indicate a statistically significant increase in average annual precipitation at the 95-percent confidence level. However, the two-sample t-test did indicate a statistically significant increase in average annual precipitation at the 90 -percent confidence level.

\section{Evaporation}

Evaporation within the study area was estimated by the South Dakota State Climatologist using a modification of the Morton (1979) method (Al Bender, South Dakota State University, written commun., 1999). The evaporation data used were obtained from Agricultural and Biosystems Engineering Department, South Dakota State University (1999). In this modification, shortwave radiation, surface temperature and cloudiness, surface dew point or humidity, and advected energy are used to estimate potential evaporation. The evaporation estimates for the study area are available for 1953-98. A more detailed discussion on the method used to estimate these data is given in the report for task 1 of this study (Northern Great Plains Water Resources Research Center, written commun., July 1999). The data are shown in figure 16 and given in table B4 of the Supplemental Information section. As with the precipitation data, the evaporation data were presented by water year and divided into tw'o semiannual periods (winter and summer) in figure 16 .

Analysis of the annual evaporation totals indicates a trend of decreased evaporation beginning in 1991. The average annual evaporation for water years 1961-90 is 32.7 in., and the average annual evaporation for water years 1991-98 is $28.7 \mathrm{in}$. A two-sample t-test indicated a statistically significant decrease in average annual evaporation at the 99.9-percent confidence level. However, the t-test may be biased by the autocorrelation in the annual evaporation data (the lag-1 autocorrelation coefficient for 1961-98 is 0.43). Thus, the apparent decrease in evaporation may be because of serial persistence, a true decreasing trend, or both. 
Bitter Lake

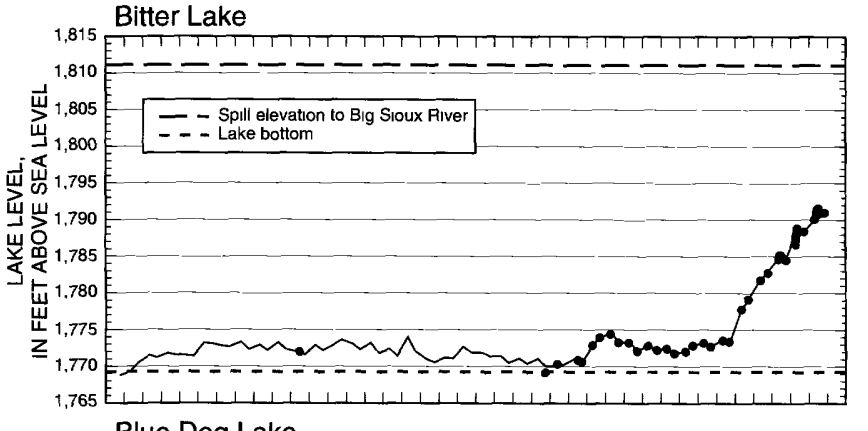

Blue Dog Lake

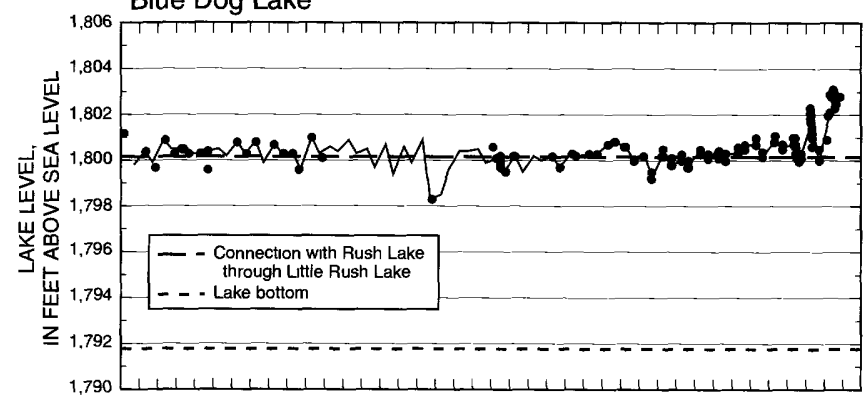

Enemy Swim Lake

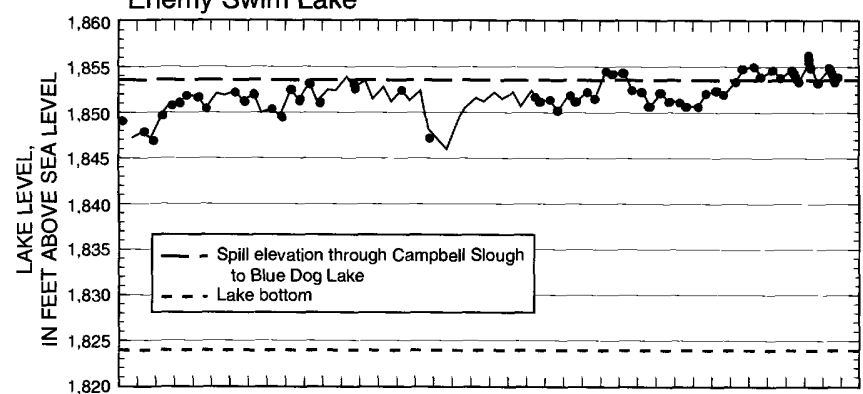

Hillebrands Lake
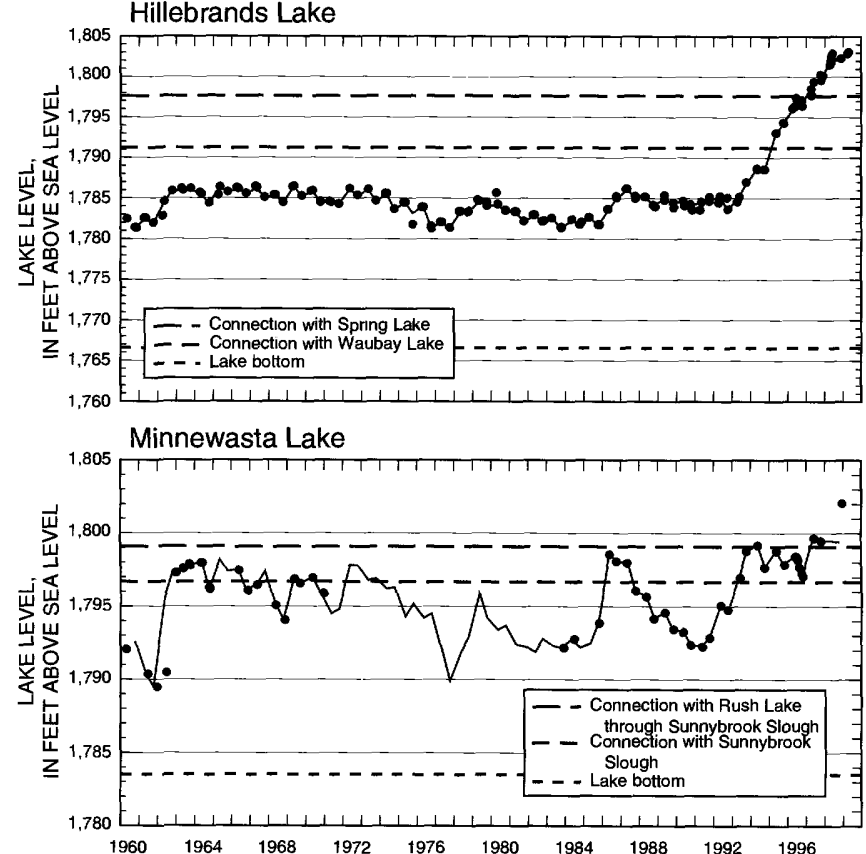

Pickerel Lake

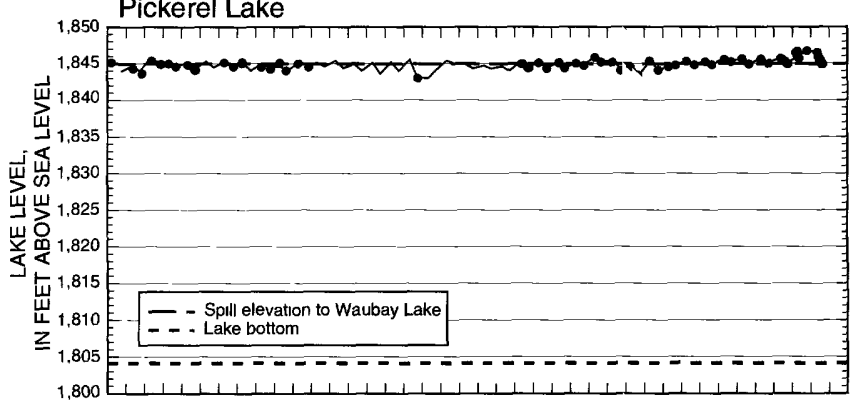

Rush Lake
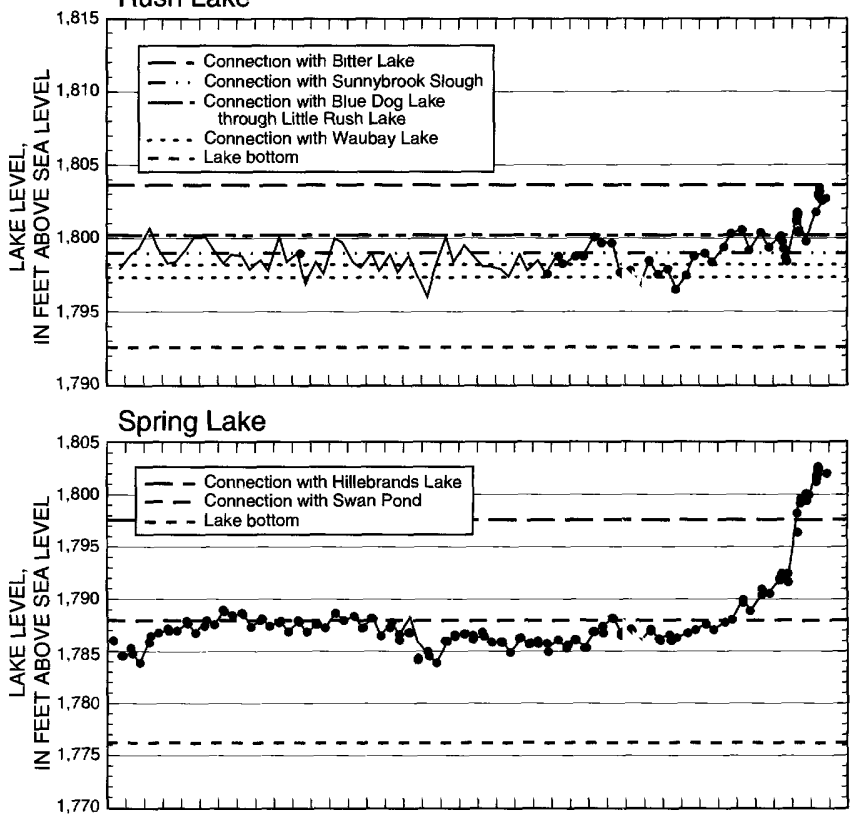

\section{Swan Pond}
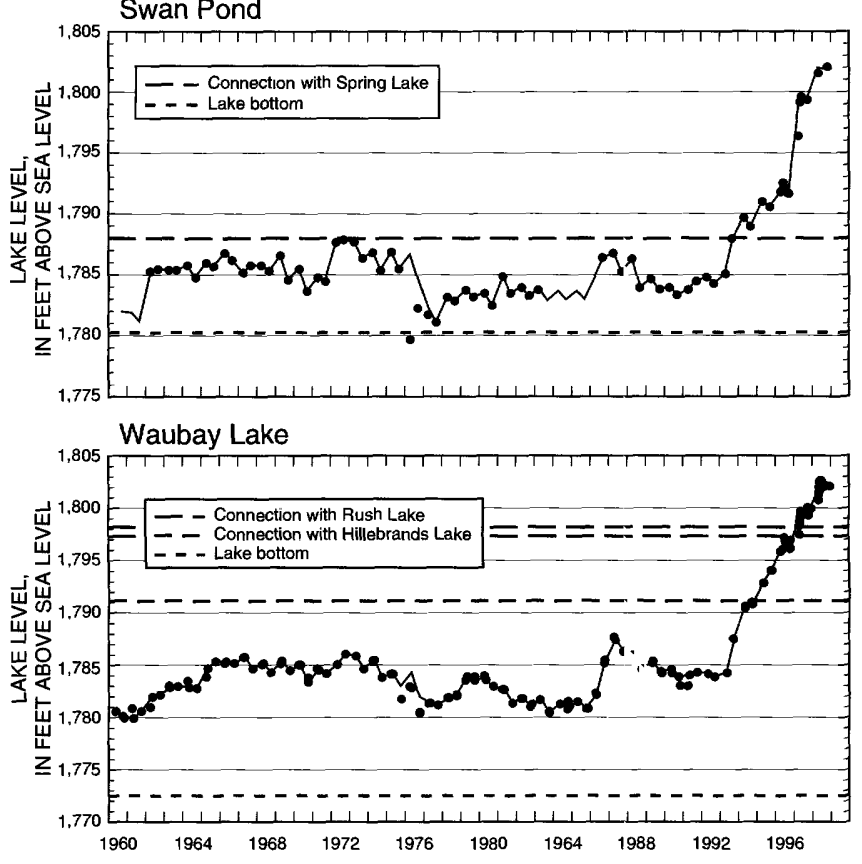

\section{EXPLANATION \\ ESTIMATED \\ - HISTORIC}

Figure 12. Estimated and historic lake levels of individual lakes within the Waubay Lakes Chain, 1960-98. 


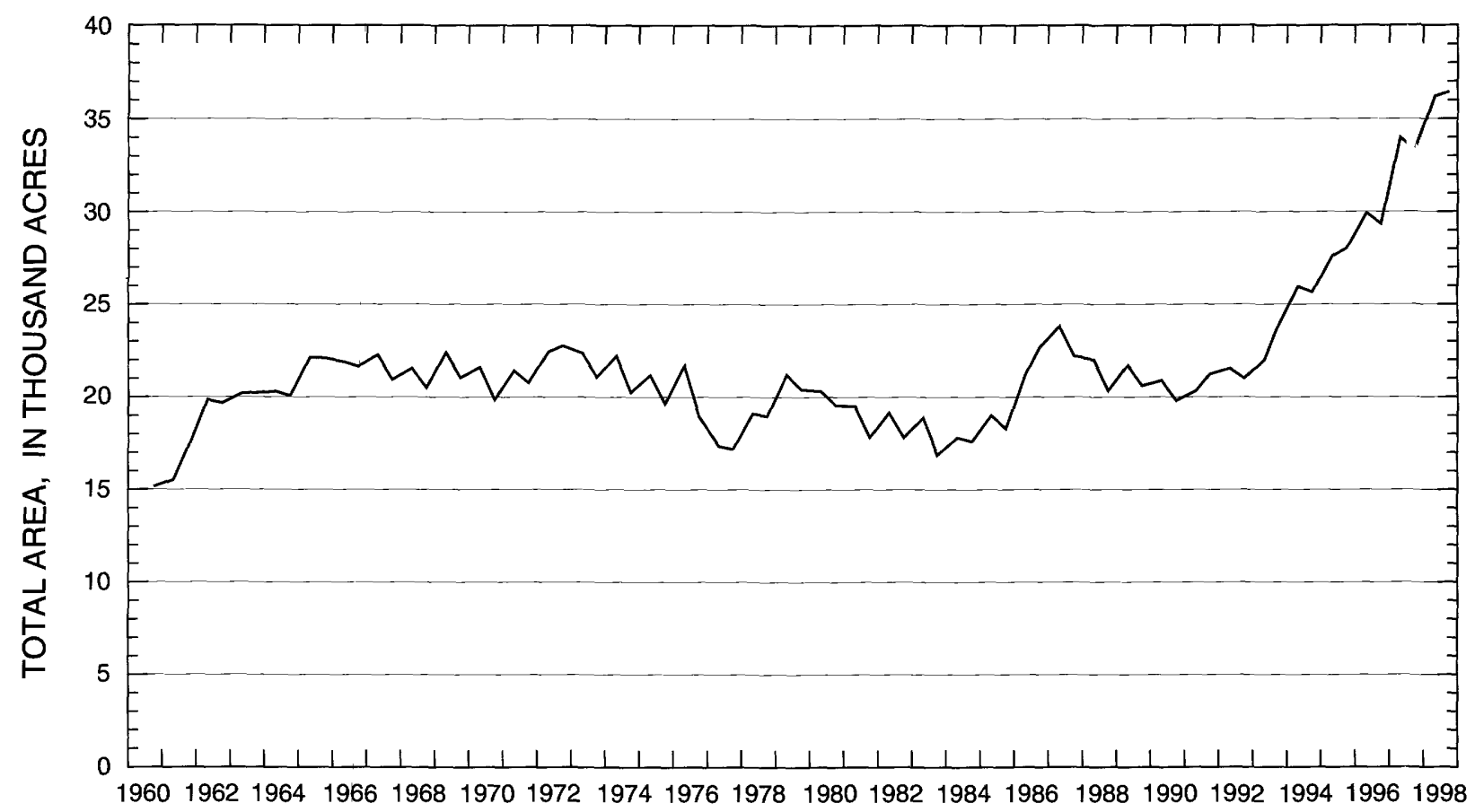

Figure 13. Estimated total lake area for $1960-98$ for the Waubay Lakes Chain.

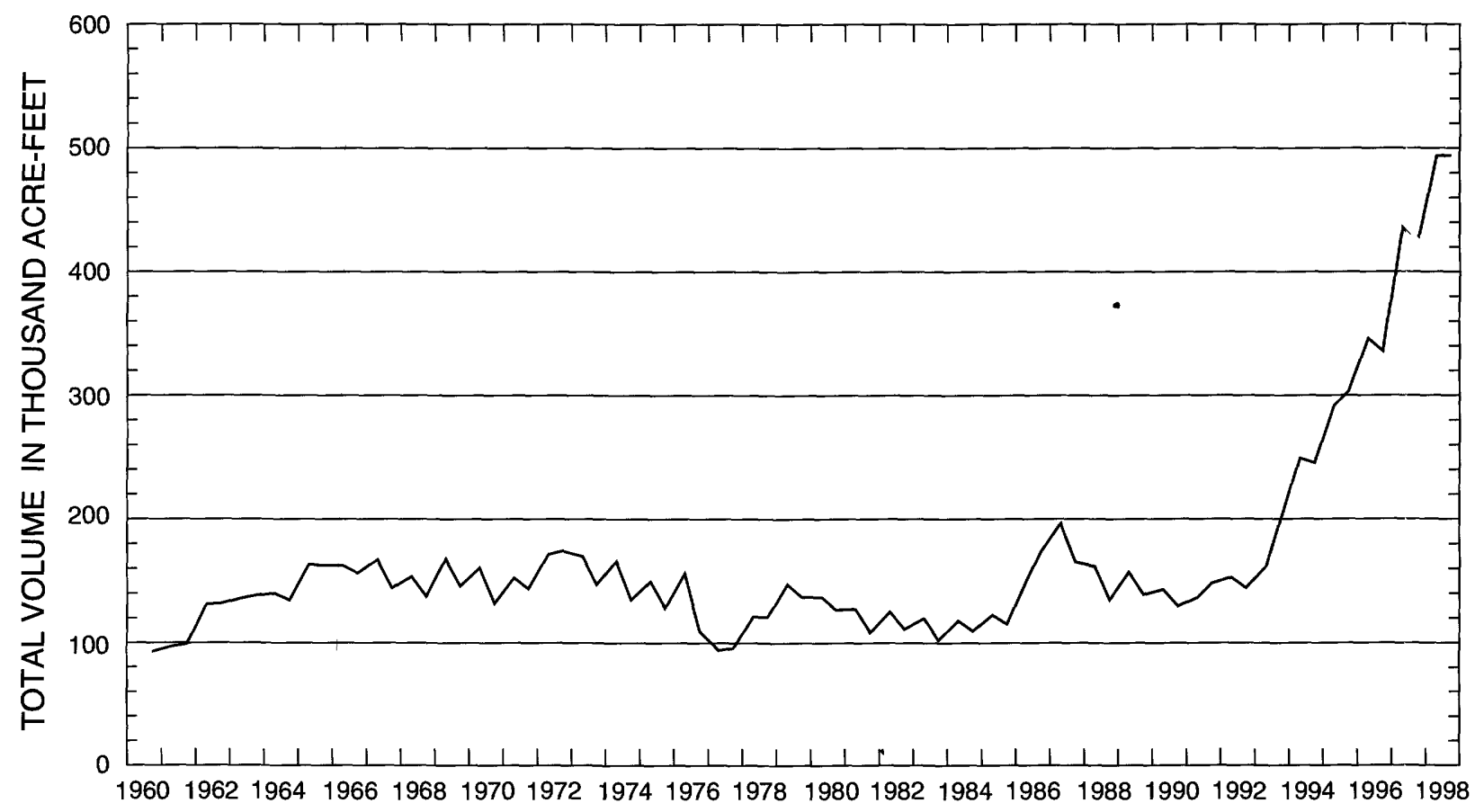

Figure 14. Estimated total lake volume for $1960-98$ for the Waubay Lakes Chain. 


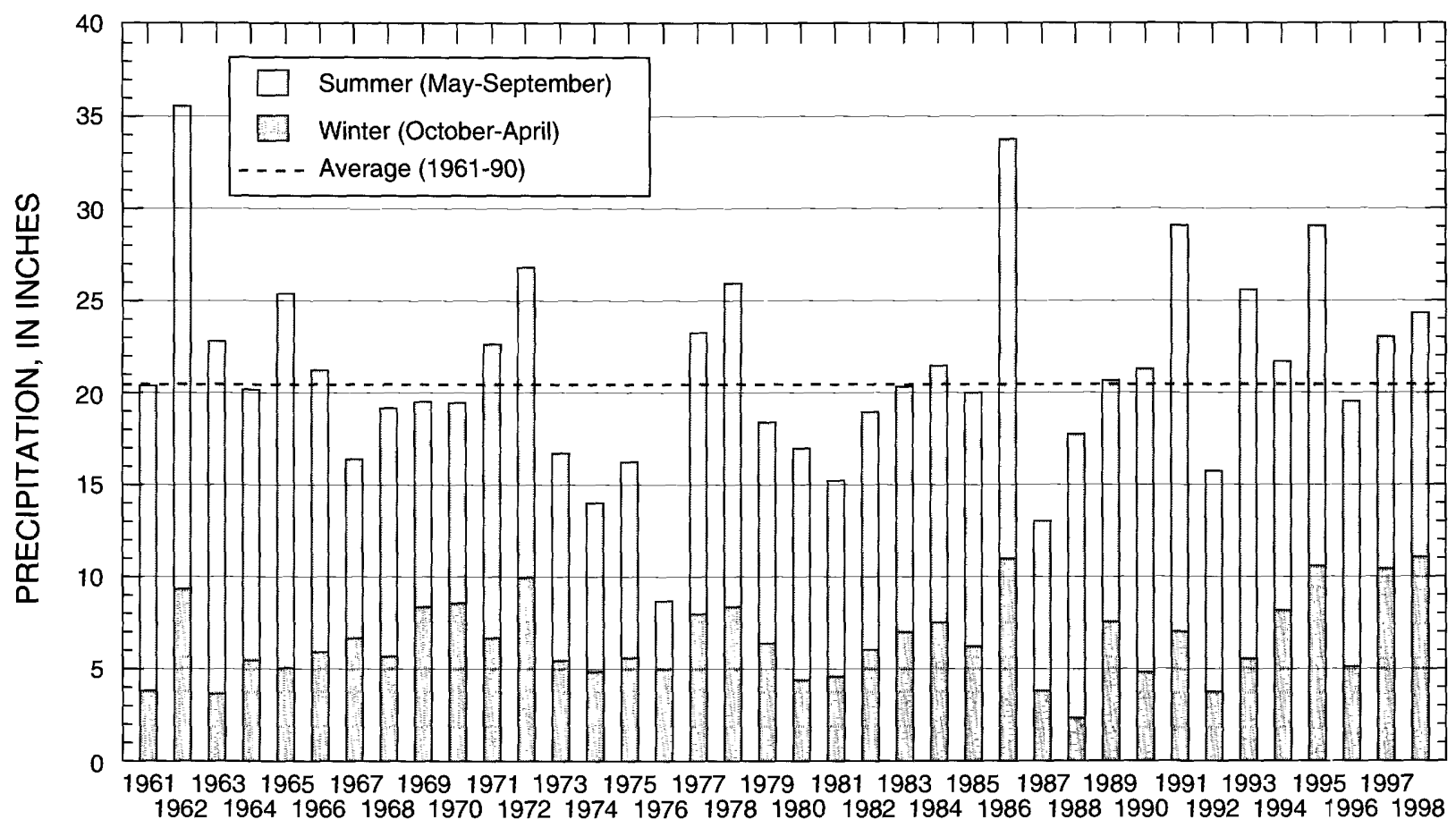

Figure 15. Seasonal precipitation for water years 1961-98 for the Waubay National Wildlife Refuge Headq' larters station (Source: National Climatic Data Center (1998) and the U.S. National Oceanic and Atmospheric Administration (1998-99)).

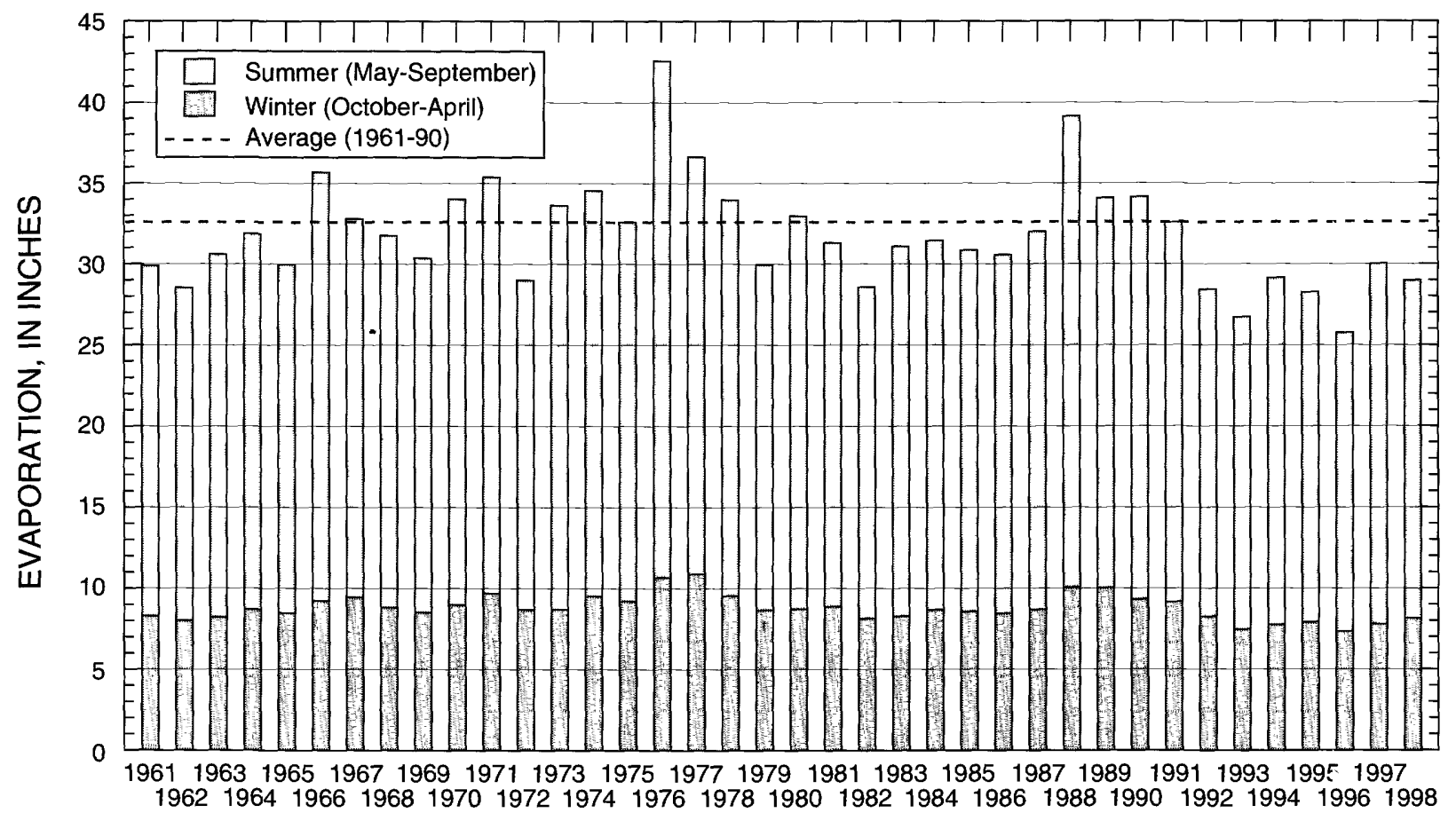

Figure 16. Seasonal estimated evaporation for water years 1961-98 for the Waubay Lakes Chain (Source: Agricultural and Biosystems Engineering Department, South Dakota State University (1999)). 
The coincident occurrence of increased precipitation and decreased evaporation have a cumulative effect. Increased precipitation and decreased evaporation need to prevail for only a few years before the effects are evident. The presence of such conditions can cause rapid change in the basin. Additionally, the same climatic conditions that produce greater-thannormal precipitation (for example, cloudy and cool) also tend to produce greater inflows and lower-thannormal evaporation. Likewise, the climatic conditions associated with lower-than-normal precipitation are typically hot and dry, and also produce low inflows and higher-than-normal evaporation. Because the basin is topographically closed and is considered to have no ground-water connection to other basins, the only way for water to enter or leave the basin is via the atmosphere. Water enters the basin only as precipitation and leaves the basin only through evaporation. Because more water has entered the study area in recent years and less water has left, storage within the basin has increased, meaning that lake levels have risen.

\section{Lake Areas and Volumes}

Lake area and capacity tables for the 10 major lakes of the Waubay Lakes Chain were needed to convert lake levels to lake volumes and determine associated storage changes. Digital contour maps were developed from bathymetric maps that were available for Blue Dog, Enemy Swim, Minnewasta, Pickerel, and Waubay Lakes (unpublished information from South Dakota Department of Game, Fish and Parks, various dates). Bathymetric data for the remaining five lakes and for any other water bodies that were considered part of the Waubay Lakes Chain were obtained through bathymetric surveys. Because the lake levels were very high during the bathymetric surveys, the surveys overlapped areas that were covered by the DEM. The surveys and the DEM generally had good agreement but were adjusted on small areas based on data from the surveys. GIS software then was used to tabulate areas at varying lake-level elevations for each of the 10 lakes, and the tabulated data were used to create area and volume equations that best fit the data. The volume between elevation contours was calculated by averaging the area of adjacent contour planes and multiplying by the contour interval. Beginning at the low point in each lake, the cumulative volume was determined for each contour.

The bathymetric maps for Blue Dog, Enemy Swim, Minnewasta, Pickerel, and Waubay Lakes showed contours of the depths of the lakes at the time the data were obtained. These maps were completed in 1964 (Blue Dog Lake), 1996 (Enemy Swim Lake), 1964 (Minnewasta Lake), 1989 (Pickerel Lake), an 1 1971 (Waubay Lake). Contour maps of the elevations of the lake bottoms were constructed by estimating lake-level elevations on the basis of when the data were collected. The contour maps then were digitized and transferred into a GIS. Reference points that had a known latitude and longitude were used to transfer the digital data into a Universal Transverse Mercator (UTM) coordinate system.

The USGS collected bathymetric data for Bitter Lake, Hillebrands Lake, Rush Lake, Spring Lake, Swan Pond, Little Rush Lake, Campbell Slough, Dahling Slough, and Sunnybrook Slough. The data were collected using a boat, fathometer, data logger, and GPS equipment. A series of transects were planned for each lake. These transects were located so as to minimize the number required to adequately determine the general shape of the lake bottom and the maximum depth. Each of the transects had many datacollection points. The GPS equipment was used to navigate to the beginning point of each transect ard to maintain a path of travel as consistent with each transect as possible. The data logger recorded fathometer depth data and time at 2- to 3-second intervals along each transect. The depth also was recorded using a separate paper-chart recorder that was marked with time. The paper-chart recorder served as a barkup and provided a record of bar checks, which were used to verify the accuracy of the fathometer. The GP? receiver recorded latitude, longitude, and time, ant the GPS antenna was used at horizontal control points to verify horizontal accuracy. By synchronizing the clocks of the receiver and the data logger, a horizontal location was assigned to each data-collection point. The lake level and any offsets between the water surface and the depth transducer were recorded at the time of data collection so that each depth measurement could be converted to an elevation. The data for each transect were plotted and bathymetric maps constructed. Using a GIS, digital contour maps then were developed from the bathymetric maps.

Digital contour maps of the land areas were developed from existing DEM's and transferred into a UTM coordinate system. The digital contour mans for all of the lakes then were joined with the DEM data from the EROS Data Center to construct a continuous digital contour map of the lakes throughout the full range of potential lake-level fluctuations. Bathymetric data for the 10 lakes are shown in figures D3 through 
D18 in section D of the Supplemental Information section. Contours for the lakes at lower lake levels are shown in figures D3 through D10, and contours for the lakes at higher lake levels are shown in figures D11 through D18. The DEM's used were developed from 7.5-minute USGS topographic quadrangle maps and sample 1 in a 10-meter grid. In some areas, the digital contour maps of the area above the lake level had to be fitted into the digital contour map of the lake bottoms. Contours were closed at the outlets solely for the purpose of determining lake areas and volumes when the lakes were at high levels.

The digital data were used to determine the lake area at each contour, and the lake volume wa- calculated on the basis of area and depth. Because no consistent method exists for interpolating between known areas or for converting estimated areas to volumes, a set of equations was developed to relate elevations, areas, an 1 volumes. These equations were developed using a nonlinear regression of lake level versus area and lake level versus volume and were used in the modeling part of this study. The equations use three shape coefficients to fit the data, and the equation for each lake begins with the same general equation:

$$
V(h)=V_{\max }\left[a h^{\prime}+\frac{0.5(1-a)(1+b)\left(1-\cos \left\{\pi h^{\prime}\right\}\right)}{\left(1-b \cos \left\{\pi h^{\prime}\right\}\right)}\right]^{(c+1)}
$$

where

$$
\begin{aligned}
V(h) & =\text { volume, in acre-feet, at lake elevation } h ; \\
h & =\text { lake elevation, in feet above sea level; } \\
V_{\max } & =\text { maximum volume, in acre-feet; } \\
h^{\prime} & =\left(h-h_{\text {min }}\right) /\left(h_{\max }-h_{\text {min }}\right), \text { a standardized elevation, for } h^{\prime}>0 ; \\
h_{\text {min }} & =\text { minimum }(\text { dry lake bed }) \text { elevation, in feet above sea level; } \\
h_{\text {max }} & =\text { maximum elevation, in feet above sea level; and } \\
a, b, & \text { and } c=\text { shape parameters used to fit data for each lake separately }(a>0, b>-1, \text { and } c>0) .
\end{aligned}
$$

$V\left(h_{\min }\right)=0$, and $V(h)$ has positive first and second derivatives for $h>h_{\min }$, which are conditions that must be satisfied by a valid volume function. The area equation obtained by differentiating $V(h)$ is:

$$
A(h)=A_{\max }\left[1+\frac{\left(\frac{\pi}{2 a}\right)(1-a)(1+b)(1-b) \sin \left(\pi h^{\prime}\right)}{\left(1-b \cos \left(\pi h^{\prime}\right)\right)^{2}}\right]\left[a h^{\prime}+\frac{0.5(1-a)(1+b)\left(1-\cos \left(\pi h^{\prime}\right)\right)}{\left(1-b \cos \left(\pi h^{\prime}\right)\right)}\right]^{c}
$$

where

$$
A(h)=\text { area, in acres, at lake elevation } h \text {, and } A_{\max }=\text { maximum area, in acres }=\frac{V_{\max } a(c+1)}{\left(h_{\max }-h_{\min }\right)} \text {. }
$$

The parameters $a, b$, and $c$ were fitted to known areas of each lake using nonlinear least-squares regression. The minimum (dry lake bed) elevation of each lake was approximated by examining the bathymetric maps or raw data where available. The fitted parameters are given in table 7 . The agreement was deemed satisfactory for each lake.

The general shape of each lake can be visualized by referring to the bathymetric maps of each lake. Some of the typical lake shapes also have typical lake level-versus-area and lake level-versus-volume curves. For example, a lake such as Blue Dog Lake, which has a wide, flat bottom and steep, bank-like sides, will have a lake area curve that shows large initial increases in area and small increases in lake level until the lake level reaches the foot of the banks. The area increases then will be small until the lake level reaches the top of the banks and the increases again become large with increasing lake level. The expected lake volume curve for the same lake would show somewhat consistent increases in volume with increasing lake level until the lake level reaches the top of the banks. The volume increases then will be more rapid with inc"easing lake level. A lake such as Pickerel Lake, which has evenly sloped sides and a v-shaped bottom, will rave consistent increases in area and lake level, but volume 
increases will be more rapid with increasing lake level. Lakes that do not fit these general descriptions will have lake area and volume curves that have some similarities with both examples, but the characteristics will be less obvious. The lake area curves for the 10 major lakes of the Waubay Lakes Chain are shown in figure 17, and the lake volume curves are shown in figure 18. The areas and volumes for $1-\mathrm{ft}$ lake-level intervals are given in table B5 of the Supplemental Information section.

\section{Total Inflow}

Total inflow to the Waubay Lakes Chain was estimated using the assumption that the Waubay Lakes Chain Basin (fig. 9) is a closed system that has no surface and subsurface inflow or outflow across its boundary. The volume of water in the system at a given time step (winter or summer) was set equal to the volume of water in the system at the previous time step plus the water from precipitation falling on the lakes minus the water evaporating from the lakes plus total inflow from surface runoff, as follows:

$$
V_{1}=V_{0}+p(A)-e(A)+I
$$

where

$$
\begin{aligned}
V_{1}= & \text { volume of water at end of time step, in acre- } \\
& \text { feet; } \\
V_{0}= & \text { volume of water at beginning of time step, in } \\
& \text { acre-feet; }
\end{aligned}
$$

$p=$ precipitation falling directly on lakes during time step, in feet;

$e=$ evaporation directly from lakes during time step, in feet;

$A=$ surface area of lakes at beginning of time step, in acres; and

$I=$ total inflow to lakes from surface runof; in acre-feet.

If evaporation, precipitation, and area/caparity relations are known for each lake within the study area, the amount of water gained by precipitation fallirg directly on each lake and the amount of water lost by evaporation directly from the lake can be estimated on the basis of lake area as determined from lake-level data. Changes in the lake level of a given lake that cannot be attributed to direct precipitation or evaporation must, therefore, be caused by inflow to or outflow from that lake. Sources of inflow to a lake include runoff of precipitation, minor gains from ground-water (springs), and interflow between lakes. Sources of outflow include minor losses to ground water (seepage) and interflow between lakes. Inflow also could include small errors resulting from the assumption of spatially uniform precipitation, estimated lake levels (when measurements were unavailable), and the closeness of fit of equations used for the lake-level and area/ capacity relations. To estimate the inflow received by the lakes from all sources except interflow betwe?n lakes, the entire closed basin was viewed as a system. Thus, the net effect of interflows between lakes was removed, and inflow consisted predominantly of runoff from the drainage basin.

Table 7. Fitted parameters for area and volume equations for the 10 major lakes of the Waubay Lakes Chain

$\left[h_{\min }\right.$, minimum (dry lake bed) elevation; $h_{\max }$, maximum elevation; $A_{\max }$, maximum area; $a, b$, and $c$, shape parameters used to fit data for each lake separately]

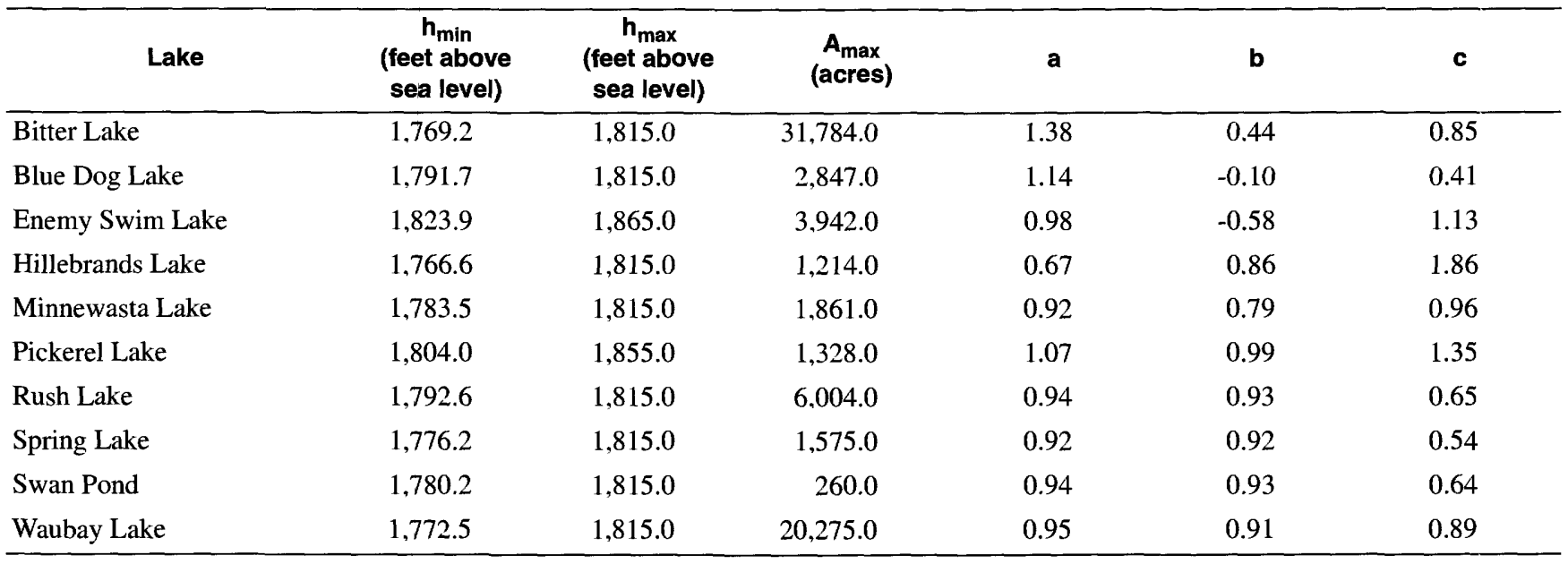


Bitter Lake
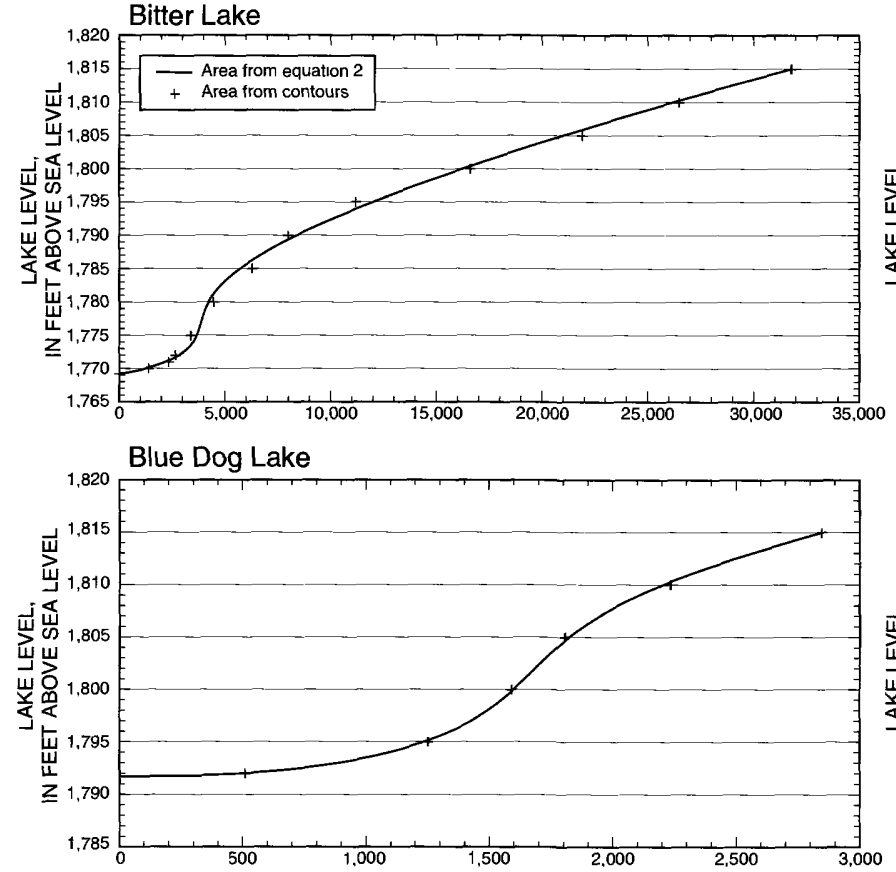

Enemy Swim Lake
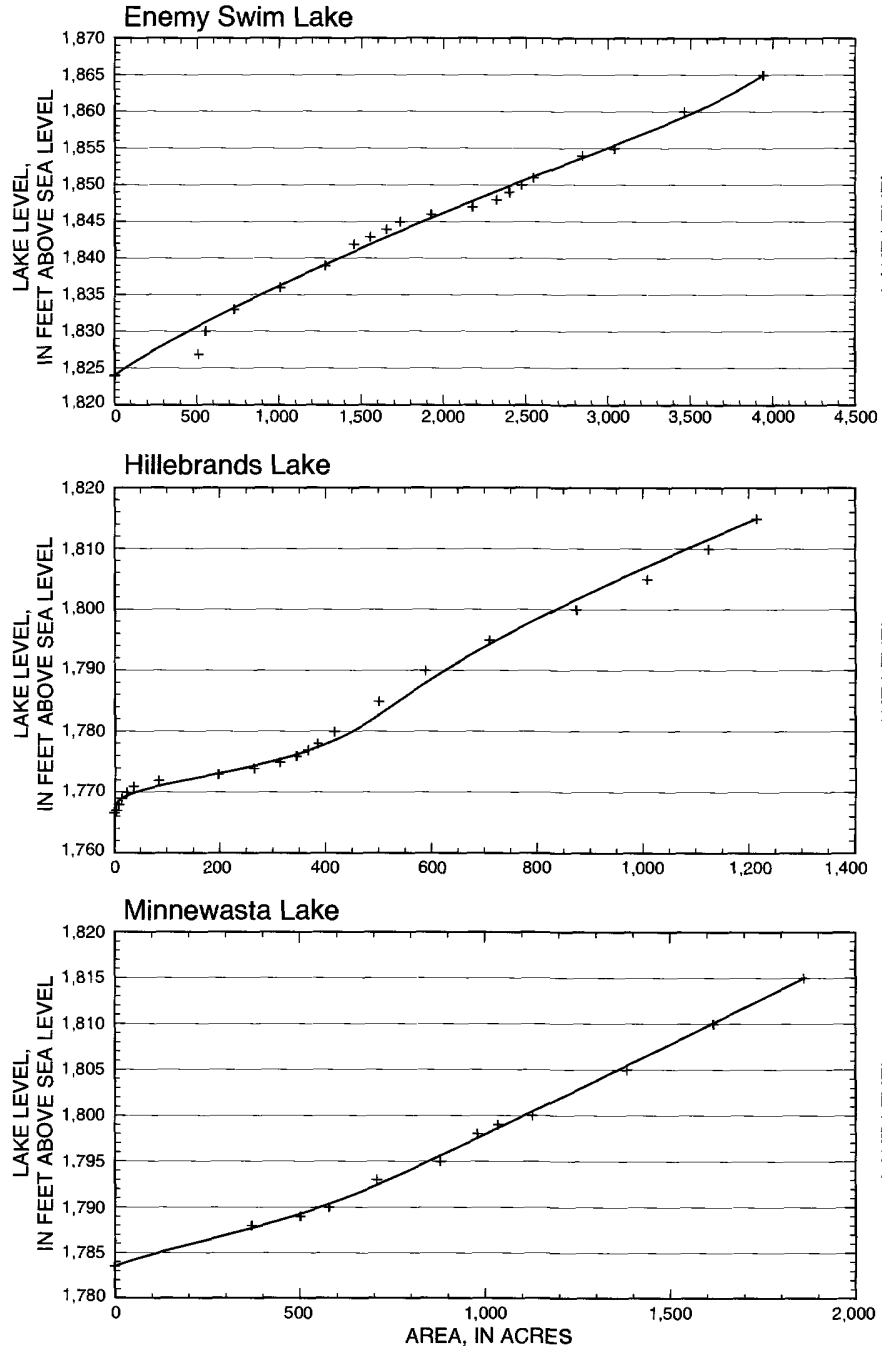
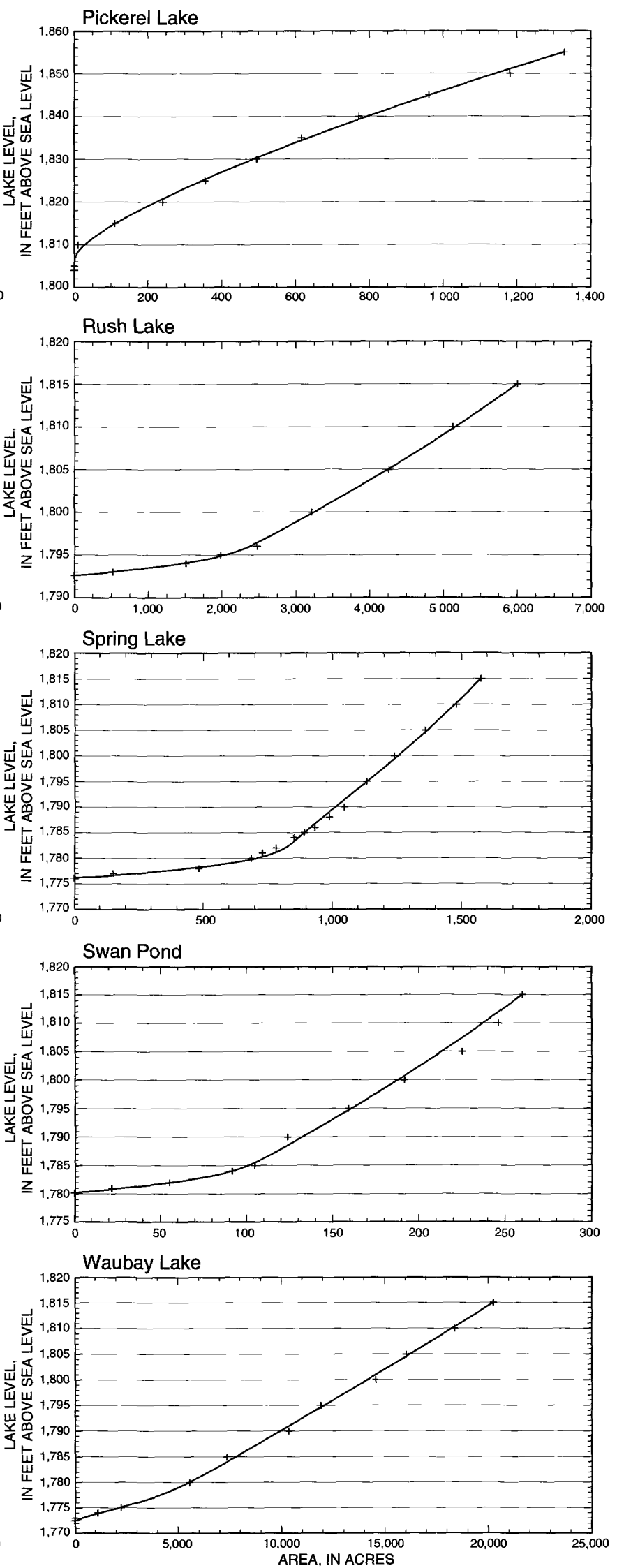

Figure 17. Lake area curves for individual lakes within the Waubay Lakes Chain. 
Bitter Lake

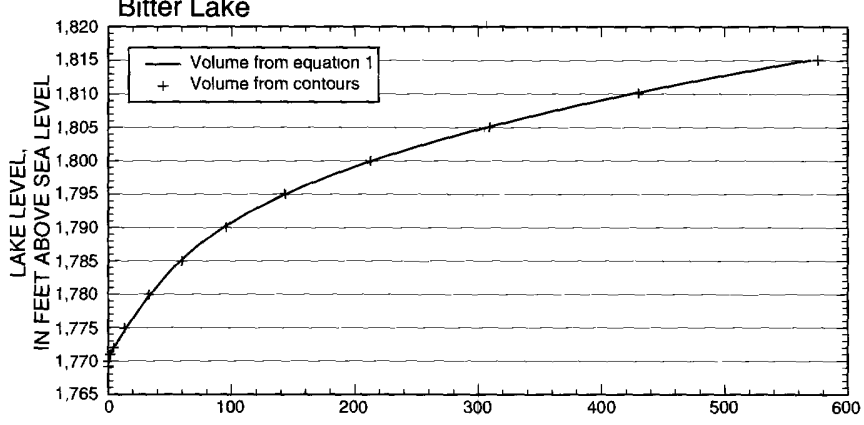

Blue Dog Lake
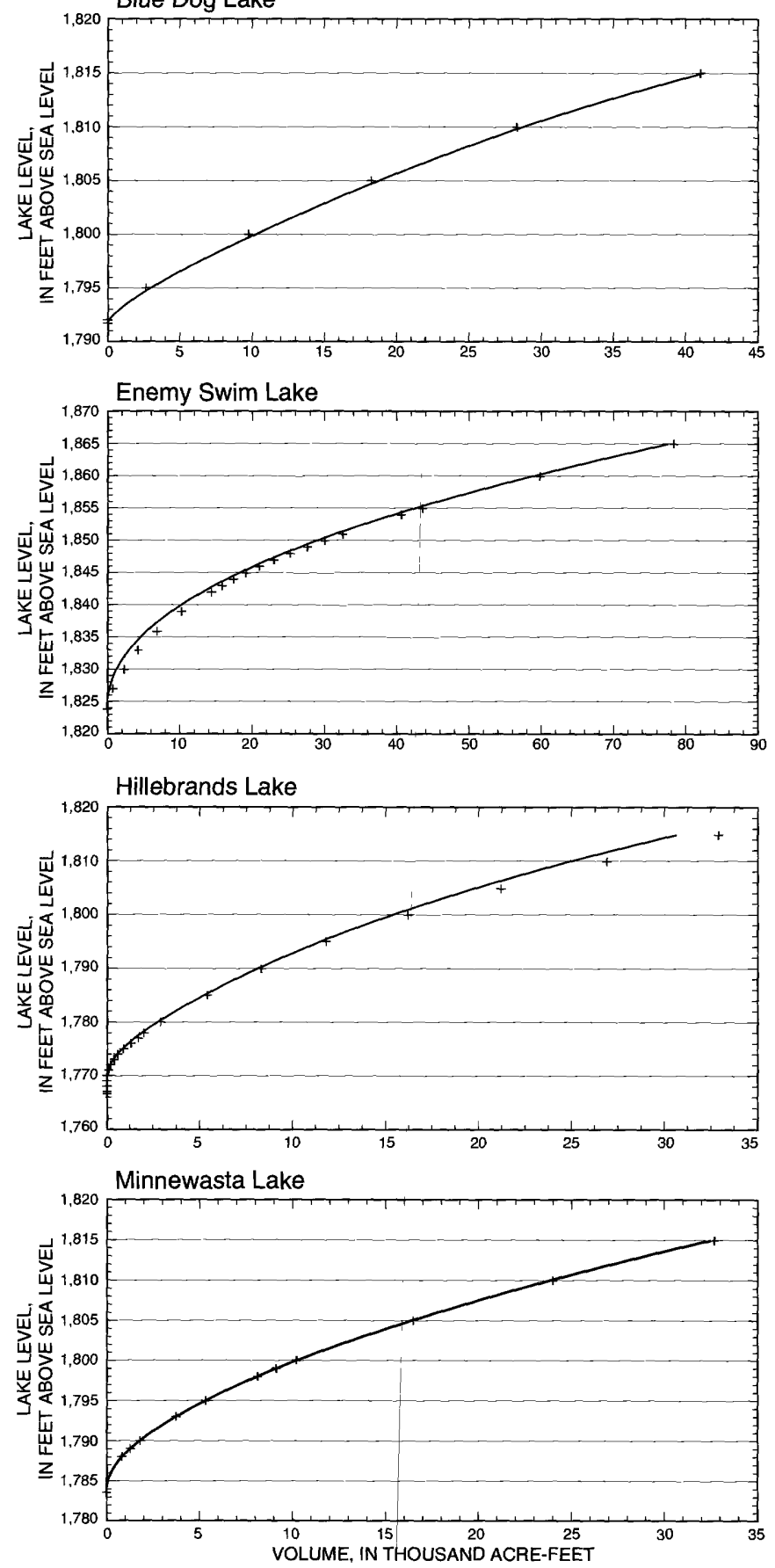

Pickerel Lake

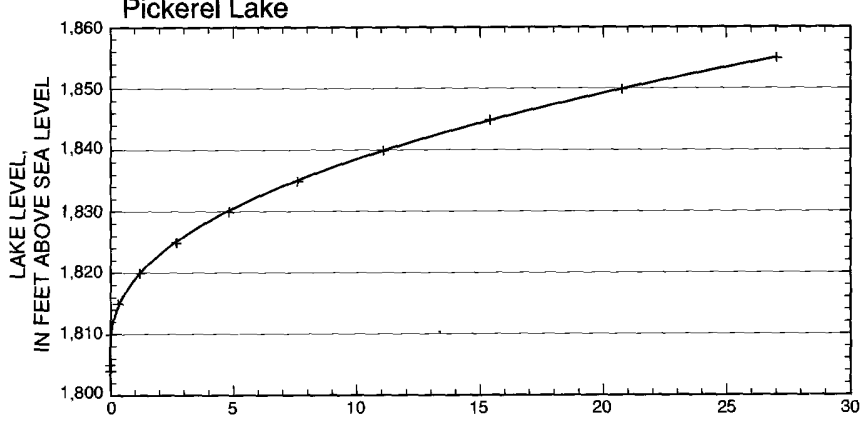

Rush Lake
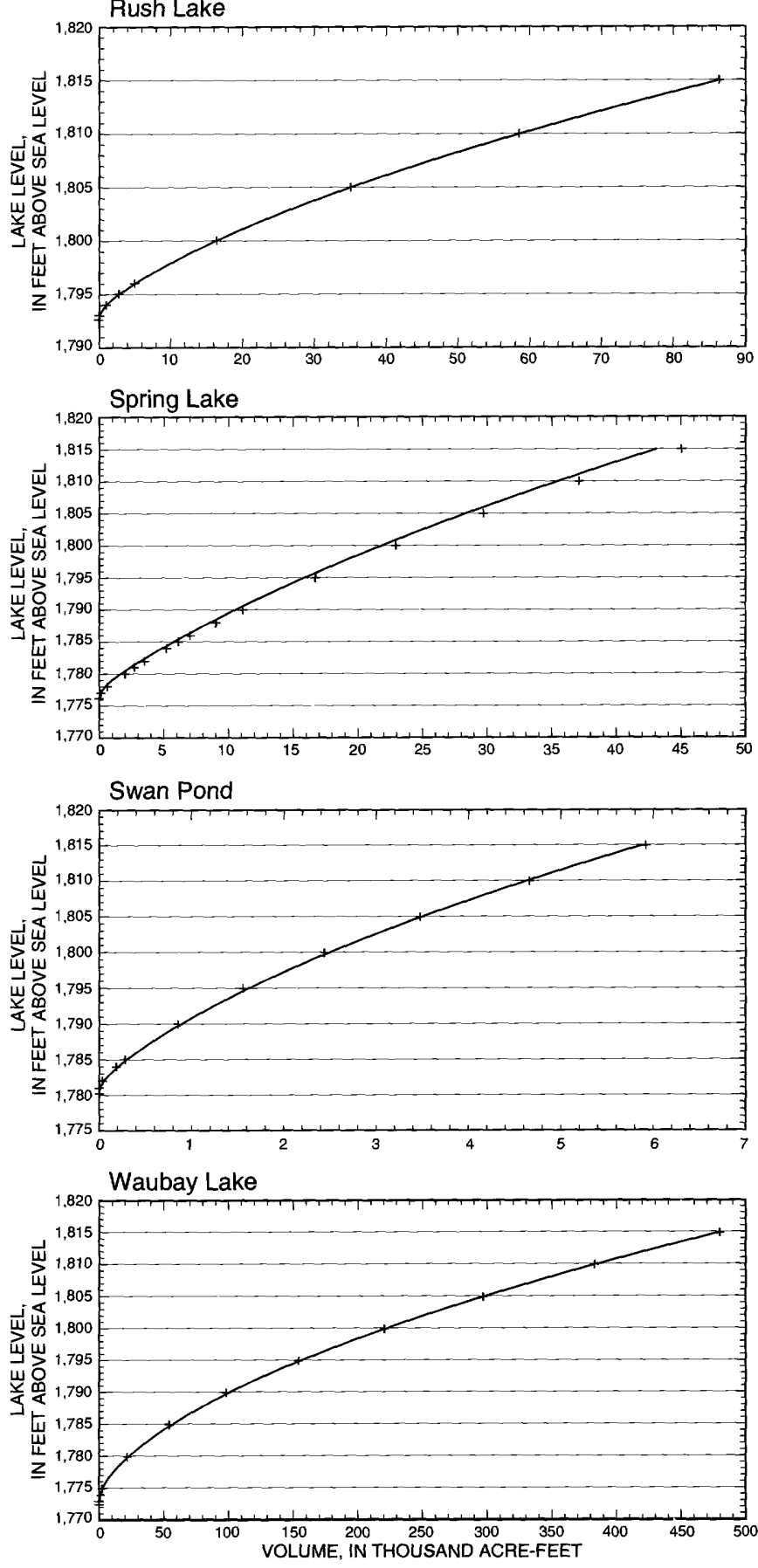

Figure 18. Lake volume curves for individual lakes within the Waubay Lakes Chain. 
Total inflow to the system was computed on a semiannual time step. The water year was selected rather than the calendar year so that snowfall would melt and run off in the same year as the snowfall occurred. Using the lake-level data developed earlier, the October 1 and May 1 lake levels were tabulated for each lake for water years 1961-98. Next, the lake-level and area/capacity relations for each lake were used to determine the lake areas and volumes corresponding to the October 1 and May 1 lake levels. Based on the semiannual precipitation and evaporation data for each year, the net atmospheric gain or loss to the lake volume was calculated using the lake area at the beginning of each time step. Total inflow for a given time step is the difference between the lake volume during one time step and the next minus the net atmospheric gain, summed for all lakes as follows:

$$
I=\left(V_{1}-V_{0}\right)-(p-e) A
$$

where

$I$ = estimated total inflow for a given time step, in acre-feet;

$V_{1}=$ total volume of lakes at end of time step, in acre-feet;
$V_{0}=$ total volume of lakes at beginning of time step, in acre-feet;

$(p-e) A=$ net atmospheric gain [(precipitation-evaporation)*area] for time step, in acre-feet; and

$\mathrm{A}=$ total area of lakes at beginning of time step, in acres.

The net atmospheric gain usually is les: than zero because evaporation usually exceeds precipitation. A negative atmospheric gain represents an atmospheric loss.

The total inflows for water years 1961-98 are shown in figure 19 and given in table B6 of the Supplemental Information section. The trends discussed earlier in the Precipitation and Evaporation sections have a strong effect on inflow. The data indicate that the five largest winter inflows and the two largest summer inflows have occurred in the last 6 years.

The negative calculated inflows shown in figure 19 can be explained by a plot of volume change versus net atmospheric gain (fig. 20). Pints that lie below the line of zero inflow and that correspond to a net atmospheric gain of less than $-10,007$ acre- $\mathrm{ft}$ probably are caused by small differences between the calculated volume change or net atmospheric gain and the actual volume change or net atmospheric gain. However, the points for winter 1977 and summer 1962 lie

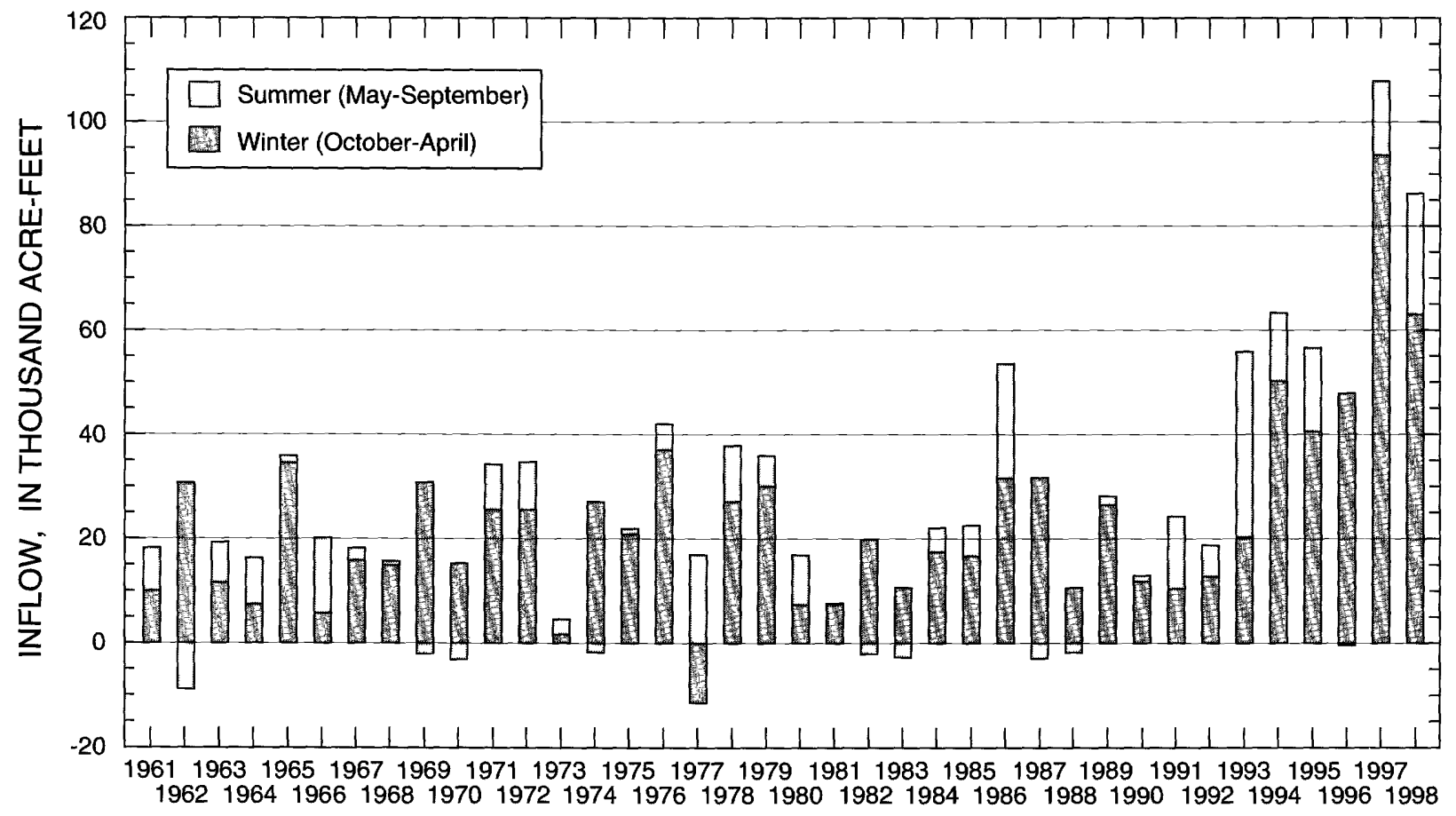

Figure 19. Total inflows for water years $1961-98$ for the Waubay Lakes Chain. 


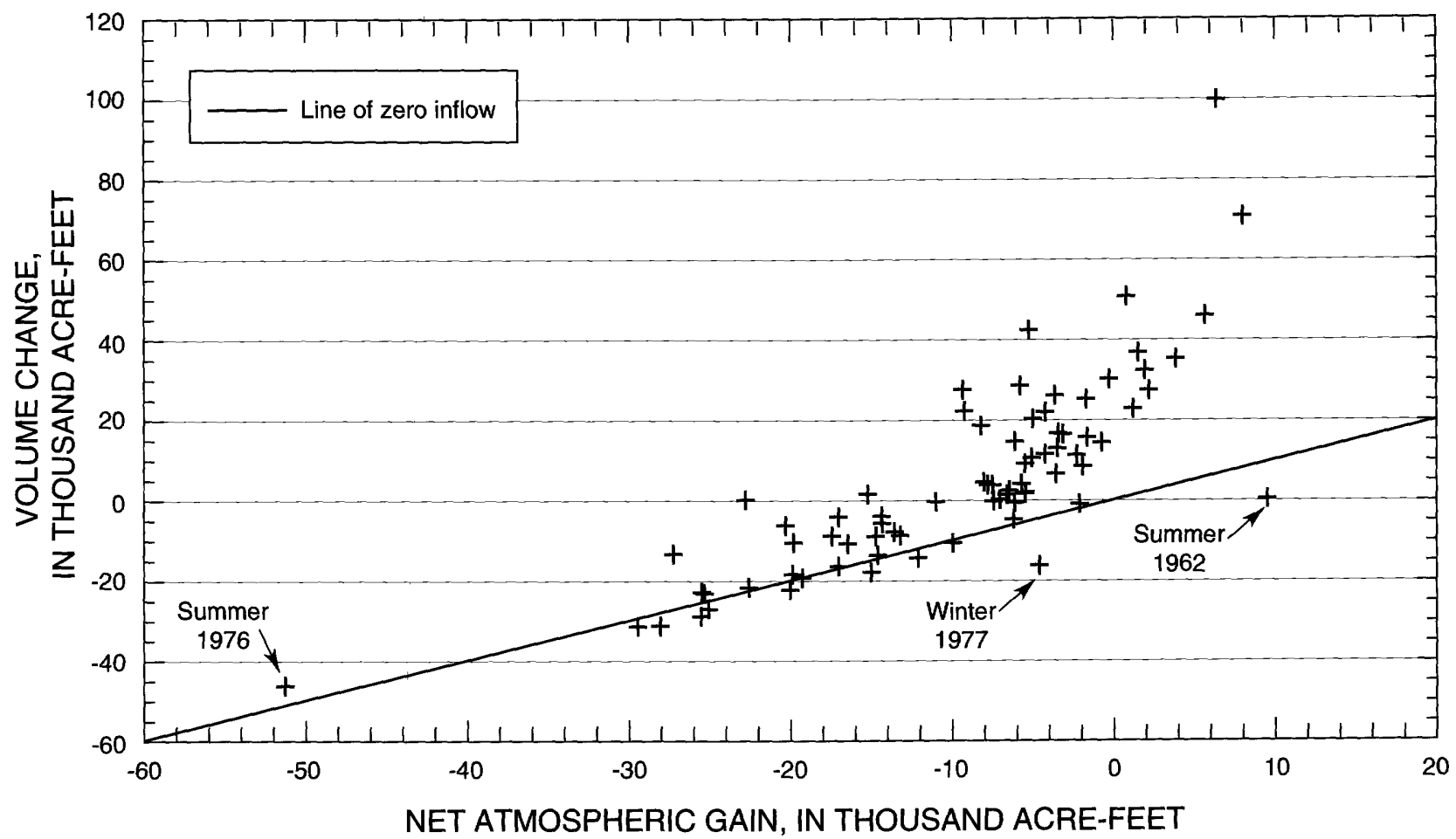

Figure 20. Semiannual volume change versus net atmospheric gain [(precipitation-evaporation)*area] for the Waubay Lakes Chain, water years 1961-98.

well below the line and cannot be attributed to inaccuracies in calculation. The lower-than-expected volume change in the winter of 1977 follows an extremely dry summer in 1976 and may be caused by water from the lakes being lost to replenish low soil-moisture levels surrounding the lakes. However, the point for summer 1962 is an extreme anomaly that has no readily apparent hydrologic cause. Although drought conditions existed in the basin in the late 1950's, inflows in the summer of 1961 and the winter of 1962 were normal given atmospheric conditions for those times. However, no inflow occurred in the summer of 1962 although it was by far the wettest summer on record. Because this extreme anomaly remains as yet unexplained, water years 1963-98 was used as the period of record for verifying the water mass-balance model.

\section{Water Mass Balance of Lakes}

Because the model includes only precipitation, evaporation, total inflow to the system, and starting lake levels as input, the total inflow needed to be apportioned among the 10 major lakes of the Waubay Lakes Chain. To apportion this inflow, equations were developed using regression on the historic data. I'ext, flow between lakes was incorporated into the model using an iterative process, if needed, to balance tr level of each lake, taking into account flow from connecting lakes. This is discussed in further detail later in the Flow Between Lakes section. Spill rating equations for flow between some lakes also were included in the model. Information was collected on the outlets of the lakes to facilitate the balancing between lakes.

\section{Inflow to Individual Lakes}

To apportion total inflow among the 10 major lakes, inflow to each lake was estimated to be approximately equal to total inflow multiplied by the drc inage area of the lake divided by the total drainage area of the Waubay Lakes Chain. The drainage area of the lake did not include the actual lake water-surface area because all precipitation falling directly on the lakes is accounted for in the precipitation data used as irnut to the model. The estimated inflows were used as a check of the final distributions of total inflow in the model.

A regression analysis, described in more detail in procedure C2 of the Supplemental Information saction, was used to obtain a more precise estimate of tro 
inflow to each individual lake. The equations resulting from this regression analysis are given in table 8. To estimate inflow to individual lakes, the simplifying assumption was made that inflow to each lake is proportional to total inflow to the system. An assumption also was made that the proportion of total inflow attributed to each lake was constant throughout the historic period. However, a satisfactory fit was not obtained using this assumption. Rather, the proportion of total inflow that needed to be attributed to the Bitter Lake drainage basin was higher during 1993-98 (the wet period) than during 1963-92. This finding is consistent with task 5 preliminary findings (U.S. Army Corps of Engineers, written commun., May 1999) that the contributing drainage area of Bitter Lake increased during the wet period. Therefore, Bitter Lake inflow was computed and removed from the total inflow, and then the remaining inflow was divided among the remaining nine lakes. The estimated proportions for 1993-98 are very close to the percent of total area values given in table 5.

Another modification of the equations used to calculate inflow to individual lakes was needed to achieve an adequate fit between historic and computed volumes for some of the lakes. Consistent gains or losses in the volumes of Enemy Swim Lake, Hillebrands Lake, Minnewasta Lake, Spring Lake, and Swan Pond remained relatively constant during
1963-98 and, thus, were not proportional to total inflow. A possible source of these gairs or losses is ground-water flow between various lakes in the system. For example, Enemy Swim Lake may discharge ground water to Spring Lake. A lthough analysis of the ground-water system is beyond the scope of this study, an intercept term was introduced into the model for some lakes in an effort to improve the fit between historic and calculated volumes. The intercept for Enemy Swim Lake ( -135 acre-ft per each semiannual period or -270 acre-ft per year; table 8 ) is consistent with a ground-water loss, and the intercept for Spring Lake ( 280 acre-ft per semiannual period or 560 acre-ft per year) is consistent with a ground-water gain. However, the estimated gain for Spring Lake is about twice as large as the estimated los` for Enemy Swim Lake. The discrepancy could be caused by an estimation error or by ground-water inflow to Spring Lake from a source other than Enemy Swim Lake. The negative intercept for Hillebrands Lake probably is not caused by ground-water loss to Spring Lake because Spring Lake was higher than Hillebrands Lake for most of the historic period. However, Hillebrands Lake may discharge ground water to Waubay Lake. The small intercept for Swan Pond (30 acre-ft per s smiannual period) and the substantial intercept for Minnewasta Lake ( 170 acre-ft per semiannual period) may indicate a source of ground-water inflow to those lakes as well.

Table 8. Water mass-balance model equations used to compute inflow for the 10 major lakes of the Waubay Lakes Chain

[I, total inflow to lakes from surface runoff, in acre-feet]

\begin{tabular}{cllc}
\hline $\begin{array}{c}\text { Model lake } \\
\text { number } \\
\text { (see fig. } 9 \text { ) }\end{array}$ & \multicolumn{1}{c}{ Lake } & \multicolumn{1}{c}{$\begin{array}{c}\text { Equation } \\
\text { (water year) }\end{array}$} & $\begin{array}{c}\text { 1993-98 } \\
\text { (water yea*) }\end{array}$ \\
\hline 10 & Bitter Lake & $0.134 * \mathrm{I}$ & $0.279 * \mathrm{I}$ \\
3 & Blue Dog Lake & $0.236 * \mathrm{I}$ & $0.195 * \mathrm{I}$ \\
2 & Enemy Swim Lake & $-135+0.150 * \mathrm{I}$ & $-135+0.124 * \mathrm{I}$ \\
6 & Hillebrands Lake & $-130+0.034 * \mathrm{I}$ & $-130+0.028 * \mathrm{I}$ \\
9 & Minnewasta Lake & $170+0.02 * \mathrm{I}$ & $170+0.016 * \mathrm{~J}$ \\
1 & Pickerel Lake & $0.104 * \mathrm{I}$ & $0.086 * \mathrm{I}$ \\
4 & Rush Lake & $0.059 * \mathrm{I}$ & $0.049 * \mathrm{I}$ \\
7 & Spring Lake & $280+0.020 * \mathrm{I}$ & $280+0.017 * \mathrm{I}$ \\
8 & Swan Pond & 30 & 30 \\
5 & Waubay Lake & $0.207 * \mathrm{I}$ & $0.216 * \mathrm{I}$
\end{tabular}




\section{Flow Between Lakes}

After inflow to each lake was estimated, an iterative balancing process was used to account for flow between lakes. This balancing process was used for all lake connections except those that spill only from the upstream lake. Also, outlet rating equations to compute flow between some lakes were developed and incorporated into the model. These curves either were developed by regression using historic data or supplied by the USACE (Rush Lake to Bitter Lake and Bitter Lake to the Big Sioux River) if no historic data existed (U.S. Army Corps of Engineers, written commun., 1999). A more detailed discussion of the algorithm to address flow between lakes is given in procedure $\mathrm{C} 3$ of the Supplemental Information section. The equations are based on spilling a percentage (sometimes raised to some exponent) of the volume available to spill. Some connections result in all of the water spilling and the lake level equalizing (for example, in backwater situations). The outlet flow-rating equations developed are shown in table 9.

Empirical (for example, data-based) flow-rating equations could not be developed for Rush Lake to Bitter Lake and Bitter Lake to the Big Sioux River because no historic data are available for when either spilled. Therefore, the spill calculations are based on daily flow ratings supplied by the USACE (Doug Clemetson, U.S. Army Corps of Engineers, oral commun., 1999). A continuous curve (relating watersurface elevation to flow) was used to approximate the outlet rating curves for Rush Lake to Bitter Lake (procedure C3 of the Supplemental Information section). If Rush Lake is above $1,811.5 \mathrm{ft}$, the railroad embankment is overtopped and flow is assumed to be unimpeded; if Rush Lake is below $1,803.6 \mathrm{ft}$ (the spill elevation with Bitter Lake), no flow is allowed. Although an assumption is made that Bitter Lake will never spill into Rush Lake, if that situation does occur the water is allowed to flow from Bitter Lake to Rush Lake until the levels of the two lakes are equal or until the level of Bitter Lake is below the spill elevation. The outlet rating curve for Bitter Lake to the Big Sioux River was computed using a daily time step, in a similar manner to the outlet rating curve for Rush Lake to Bitter Lake.

Possible flow directions between lakes are shown in figure 1. Pickerel Lake, when above its spill elevation, flows into Waubay Lake, and Enemy Swim
Lake, when above its spill elevation, flows into Blue Dog Lake. All other lakes (except Bitter Lake), when above their spill elevations, flow directly or indirectly into Waubay Lake until Waubay Lake reaches an elevation of 1,803.6 ft. Above an elevation of 1,797.6 ft, Hillebrands Lake, Spring Lake, Swan Pond, and Waubay Lake essentially are one lake, and above an elevation of 1,800.2 ft, Blue Dog Lake, Minnewasta Lake, and Rush Lake also essentially are one lake. Above an elevation of $1,803.6 \mathrm{ft}$, these two groups of lakes begin to flow to Bitter Lake. Bitter Lake, above an elevation of $1,811.1 \mathrm{ft}$, will spill south to the Big Sioux River and, above an elevation of $1,812.1 \mathrm{ft}$, also will spill east to the Big Sioux River.

The lake connections (table 9) are ordered approximately according to spills from upstream to downstream lakes. Therefore, the flows between lakes were calculated sequentially. For the first four spills (Pickerel Lake to Waubay Lake, Enemy Swim Lake to Blue Dog Lake, Blue Dog Lake to Rush Lake, and Rush Lake to Waubay Lake), an empirical flow rating was developed to regulate each of the spills, given that the upstream and downstream lakes are separate bodies of water.

Flow between lakes then was incorporated into the model. Flows from Enemy Swim and Pickerel Lakes were addressed first because the lake levels of other downstream lakes do not affect the lake levels of these two lakes. As previously discussed, rating equations were used to estimate the amount of water spilled from these lakes.

The iterative balancing process (procedure $\mathrm{C} 4$ of the Supplemental Information section) then was used to simulate flow between seven of the eight remaining lakes (the Bitter Lake to Big Sioux River connection will be discussed later) because their lake levels are affected by the neighboring lakes. The lake levels of the lakes, in relation to the spill elevation between them, fall into four possible conditions. These conditions are as follows: (1) Both lakes can be at or below the spill elevation (the elevation at the inlet/outlet between the lakes); (2) both lakes can be above the spill elevation; (3) the first lake (usually the upstream lake) can be above the spill elevation, and the second lake (usually the downstream lake) can be below the spill elevation; and (4) the first lake can be below the spill elevation and the second lake can be above the spill elevation. 
Table 9. Water mass-balance model rating equations used to compute flow between the 10 major lakes of the Waubay Lakes Chain

[vaval, volume available above spill elevation; $\leq$, less than or equal to; >, greater than; --, no flow restriction]

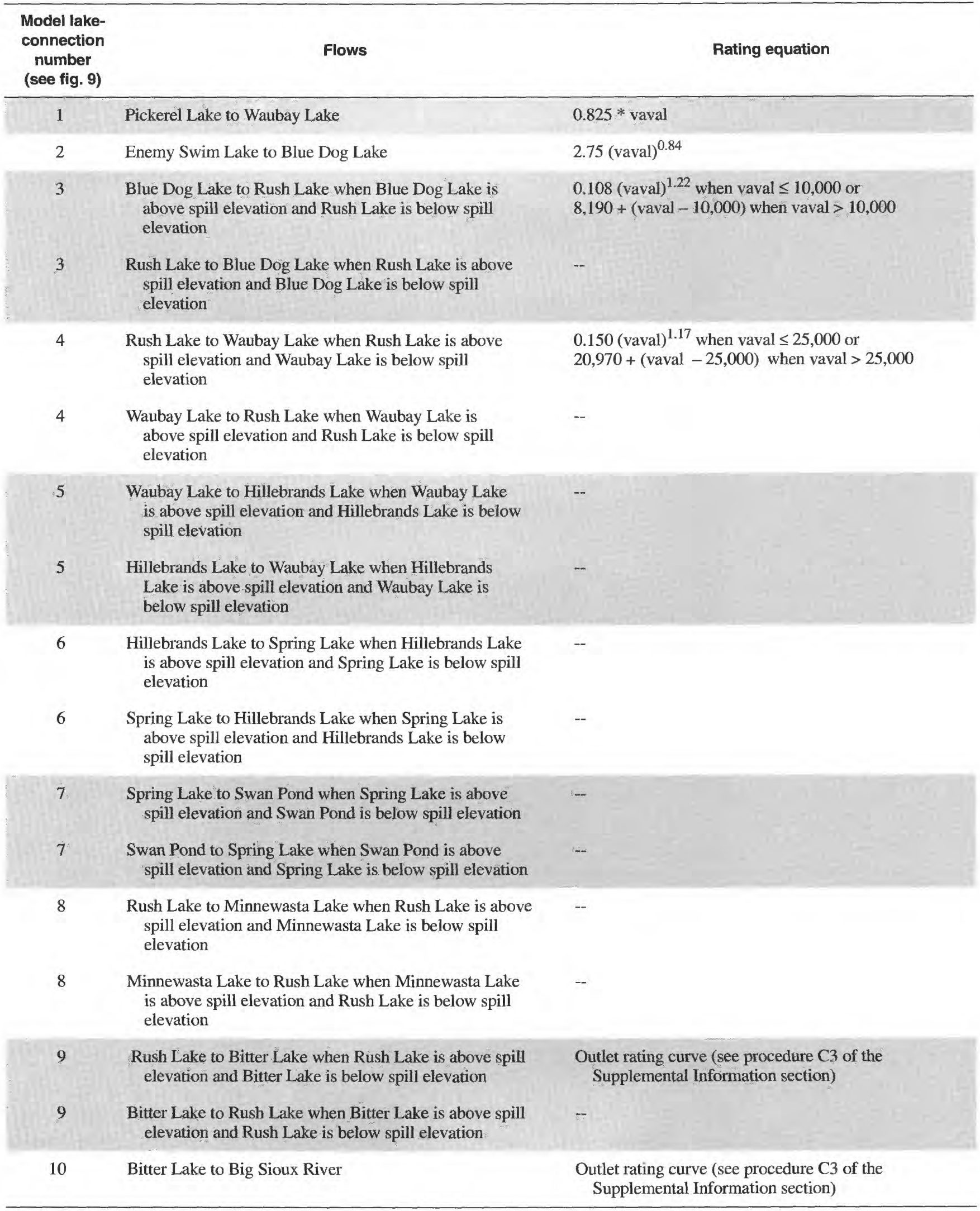


In condition 1, no flow occurs between the lakes, and the iterative balancing process is not needed.

In condition 2 , the lake levels are simply equalized to a common lake level using an area-weighted procedure to level the lakes to the same elevation. The area-weighted procedure is as follows:

Equalized lake level in lakes 1 and $2=$

$$
\left(\operatorname{area}_{1} * \operatorname{level}_{1}+\operatorname{area}_{2} * \operatorname{level}_{2}\right) /\left(\operatorname{area}_{1}+\operatorname{area}_{2}\right) .
$$

In condition 3, water is allowed to spill from the upstream lake to the downstream lake using a rating equation. If the amount of water available from the upstream lake is not enough to fill the downstream lake above the spill elevation, the upstream lake spills as much as possible using any applicable rating equations. This spilling is allowed only once in the iterative balancing process. If the amount of water available from the upstream lake is enough to fill the downstream lake above the spill elevation, the downstream lake is filled 1 acre- $\mathrm{ft}$ above the spill elevation. The lakes now are balanced under condition 2 .

In condition 4, if the amount of water available from the downstream lake is not enough to fill the upstream lake above the spill elevation, the downstream lake spills as much as possible until it reaches its spill elevation. The lakes now fall under condition 1 . If the amount of water available from the downstream lake is enough to fill the upstream lake above the spill elevation, the upstream lake is filled 1 acre-ft above the spill elevation. The lakes now are balanced under condition 2.

After the levels of the first two lakes are balanced, another lake connection is introduced. After the levels of the second two lakes are balanced, the previous lakes are rebalanced, taking into account the lake-level changes introduced by the new lake connection. This process is continued until all lakes are balanced for a particular time step. The same process is repeated for each time step, using conditions from the preceding time step as starting conditions for each succeeding time step.

The Rush Lake to Bitter Lake connection differs from the other lake connections in that the lake levels of the two lakes fall into seven possible conditions. Although an assumption is made that Bitter Lake will never spill into Rush Lake, this possibility is allowed for in the model. The seven conditions are as follows: (1a) Both lakes are at or below the spill elevation (1803.6 ft); (2a) both lakes are above the elevation
$(1,811.5 \mathrm{ft})$ of a railroad embankment located solth of Little Rush Lake about 1 mi west of Waubay; (3a) Rush Lake is above the elevation of the railroad embankment and Bitter Lake is at or below that elevation; (4a) Bitter Lake is above the elevation of the railroad embankment and Rush Lake is at or below that elevation; (5a) Bitter Lake is at or below the spill elevation $(1,803.6 \mathrm{ft})$ and Rush Lake is above the spill elevation; (6a) Rush Lake is above the spill elevation and at or below the elevation of the railroad embankment, and Bitter Lake is at or below the level of Rush Lake; (7a) Rush Lake is above the spill elevation and below the elevation of the railroad embankment, and Bitter Lake is above the level of Rush Lake and at or below the elevation of the railroad embankment.

In condition 1a, no flow occurs between the lakes, and the iterative balancing process is not neaded. In condition $2 \mathrm{a}$, the lake levels are simply equalized to a common lake level using an area-weighted procedure to level the lakes to the same elevation. The areaweighted procedure is the same as that used for condition 2 (eq. 5 ). In condition $3 a$, all water abc ve an elevation of $1,811.5 \mathrm{ft}$ is spilled to Bitter Lake or until Bitter Lake is filled above $1,811.5 \mathrm{ft}$. Then, the water balancing between the lakes is addressed by an applicable new condition. In condition $4 \mathrm{a}$, all water above an elevation of $1,811.5 \mathrm{ft}$ is spilled to Rush Lake or until Rush Lake is filled above $1,811.5 \mathrm{ft}$. Then, the water balancing between the lakes is addressed ty an applicable new condition. In condition 5a, if the amount of water available from Rush Lake is no+ enough to fill Bitter Lake above the spill elevation, Rush Lake spills as much as possible until it reacl ' ${ }^{-}$its spill elevation. These lakes now fall under condition 1a. If the amount of water available from Rush Lake is enough to fill Bitter Lake above the spill elevation, Bitter Lake is filled 1 acre-ft above the spill elevation. The lakes now are balanced under the applicable condition. In condition 6a, Rush Lake spills to Bitter Lake using an outlet rating curve. In condition 7a, lake levels are simply equalized to a common lake level using an area-weighted procedure to level the lakes to the same elevation. The area-weighted procedure is the same as that used for condition 2 (eq. 5).

The Bitter Lake to Big Sioux River connection was addressed by allowing spill from Bitter Lake if the lake level was above the spill elevation of $1,813 \mathrm{ft}$. The volume spilled was governed by an outlet rating curve.

An algorithm that describes lake-level balancing in more detail is given in procedure C3 of the Supplemental Information section. 


\section{Verification Using Historic Data}

Results of the water mass-balance model for each individual lake were verified using historic 1963-98 data. The historic record must be reproduced by the model as closely as possible, with allowance for errors in the historic record. Historic semiannual precipitation and evaporation data and computed total inflow for the Waubay Lakes Chain were input into the model. Simulated and historic lake levels, areas, and volumes are shown in figures 21 through 23, and simulated lake levels, areas, and volumes for each lake and each time step are given in tables B7 through B9 of the Supplemental Information section.

The match between simulated and historic lake levels (fig. 21) was good; differences generally were less than $1 \mathrm{ft}$. However, some of the lakes, such as Bitter, Pickerel, Spring, and Waubay Lakes, have a consistently better match than others. Simulated and historic lake levels for Swan Pond generally were inconsistent. However, considering that Swan Pond was assigned a fixed inflow (table 8) it is reasonable that the simulated water levels would match more closely in some periods than others. Given the relative size of Swan Pond (about 1 percent of the total area and the volume of the Waubay Lakes Chain), differences in this lake are minor when the system is considered as a whole. The matches between simulated and historic lake areas (fig. 22) and simulated and historic lake volumes (figs. 23) also were good. As with lake levels, Bitter, Pickerel, Spring, and Waubay Lakes had a somewhat better match than other lakes.

Each historic value represents a specific point in time, and the data collected after 1996 often were associated with peak values recorded after rainfall events. The simulated values represent the expected values for the end of each time step, given that daily precipitation and evaporation values were summed for the time step. Thus, the simulated values should not be expected to produce peak values of a duration that is much shorter than the time step. Errors in the simulated values may be from possible errors in the precipitation and evaporation input. The assumption that precipitation was spatially constant throughout the basin could cause some errors, and the evaporation values are the best estimates available on the basis of data from the Brookings station. Other errors could be introduced from estimated lake levels where no historic record exists and from small errors in lake bathymetric maps and the area/capacity equations for individual lakes.
Results of the water mass-balance model for the Waubay Lakes Chain, treated as one system, also were verified using historic 1963-98 data. As discussed earlier, lake-level data were not available for each lake in each year during 1963-98. Therefore, to estimate the historic areas and volumes, the estimated lake levels were used. The results were determined by summing the results for the 10 lakes. Simulated and estimated lake areas and volumes are shown in fig'ure 24, and simulated lake levels, areas, and volumes for each lake are given in tables B7 through B9 of the Supplemental Information section. The simulated areas and volumes of the Waubay Lakes Chain compare closely to the estimated areas and volumes.

\section{STOCHASTIC TIME-SERIES MODEL}

The stochastic time-series model (available at the USGS Subdistrict office in Huron, $\mathrm{r}$. Dak.) was developed to generate hypothetical future sequences of semiannual precipitation, evaporation, and total inflow. The model was constructed and verified using historic 1963-98 (water years) precipitation, evaporation, and total inflow data.

The stochastic time-series model generated precipitation, evaporation, and total inflow data that are statistically indistinguishable from the listoric data. The model also reproduced the cross ccrrelations between annual precipitation, evaporation, and total inflow. The results of this model were $u^{\text {sed }}$ as input for the water mass-balance model to do an unconditional and conditional frequency analysis of t $\mathrm{t}$. Waubay Lakes Chain.

\section{Fitting Procedure}

The stochastic time-series model fitting procedure used in this study is similar to the procedure used by Wiche and Vecchia (1996) to model seasonal precipitation, evaporation, and inflow for Devils Lake, N. Dak. The six time-series variables that needed to be included in the model were winter and summer precipitation, winter and summer evaporation, and winter and summer total inflow. The historic data for the six variables for water years 1961-98 are show 7 in figures 15 , 16 , and 19. Because of the anomalous calculated total inflow value for the summer of 1962, as indicated previously, 1963-98 was used as the period of record for verifying the stochastic time-series model. 
Bitter Lake

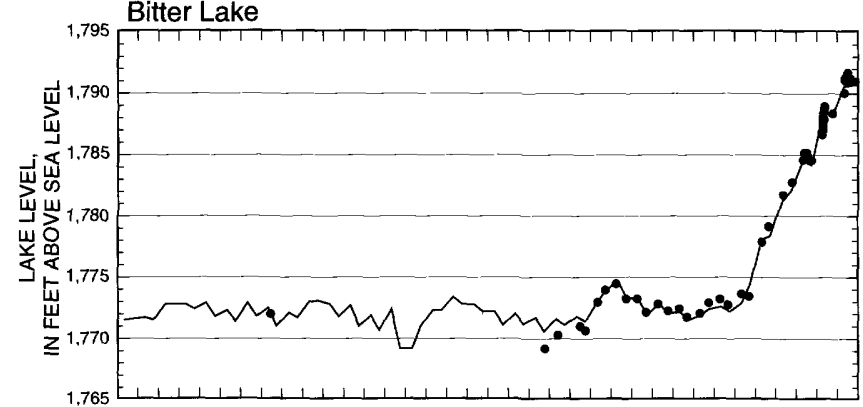

Blue Dog Lake

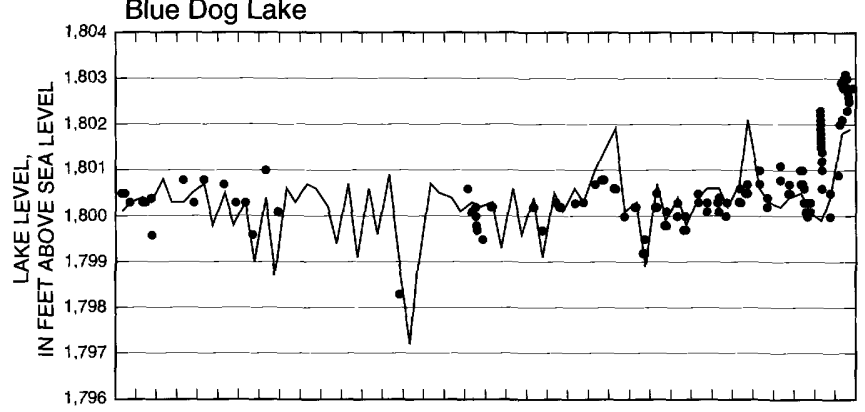

Enemy Swim Lake

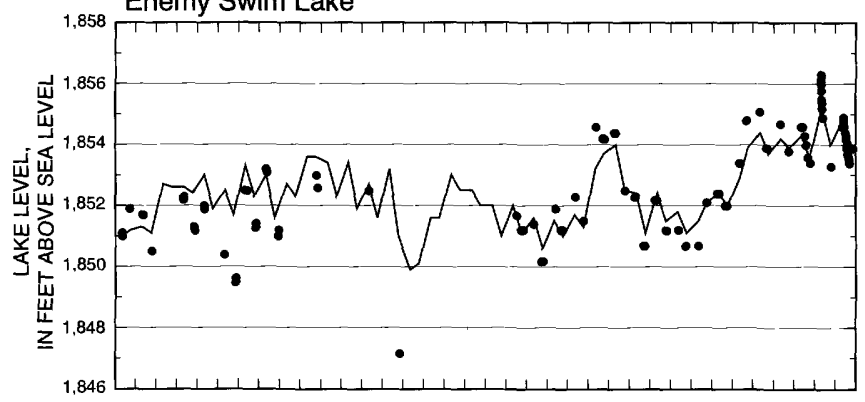

Hillebrands Lake

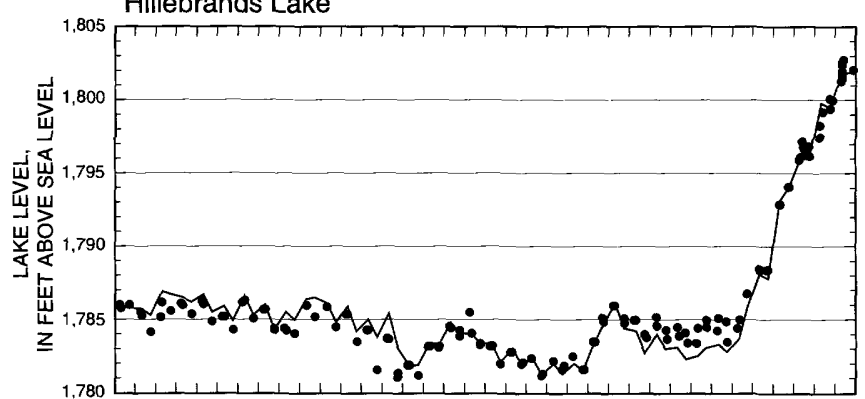

Minnewasta Lake

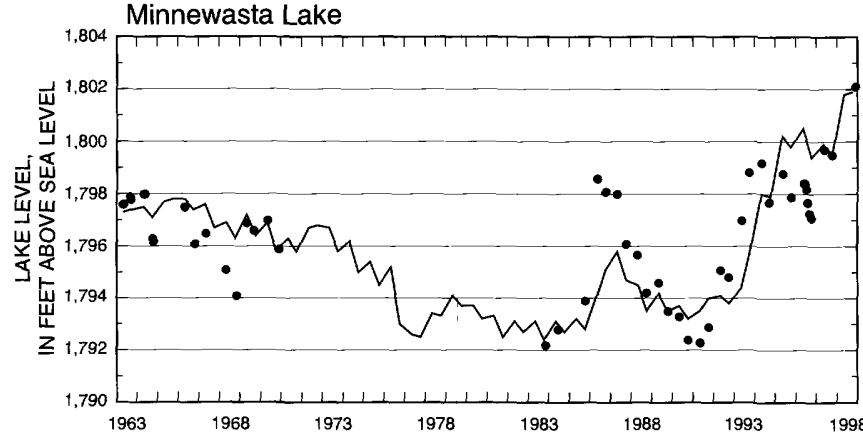

Pickerel Lake

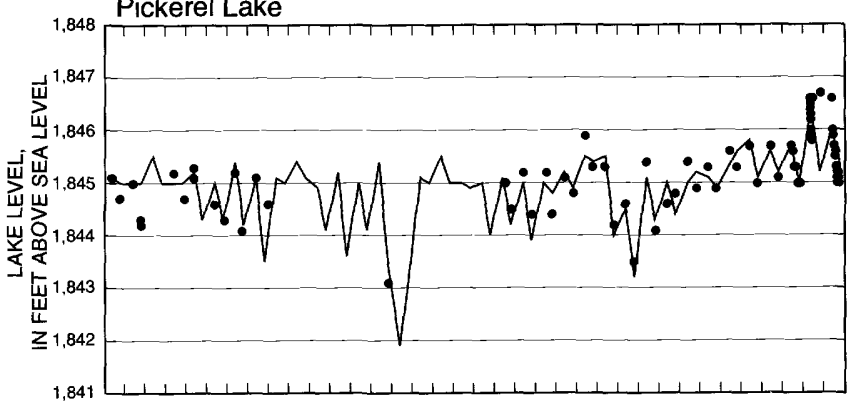

Rush Lake

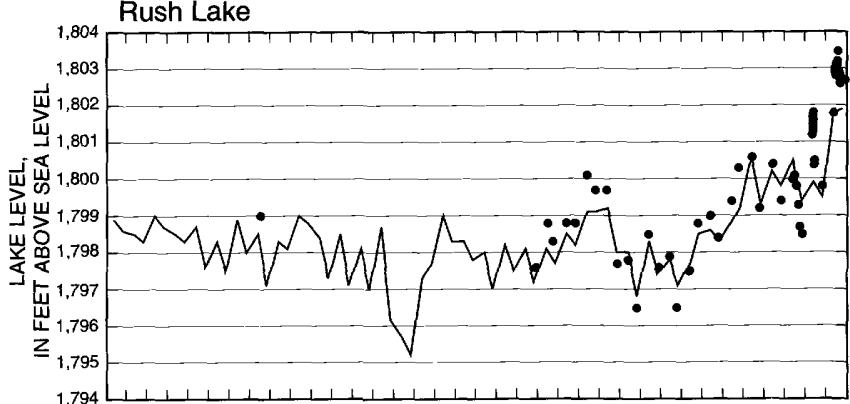

Spring Lake
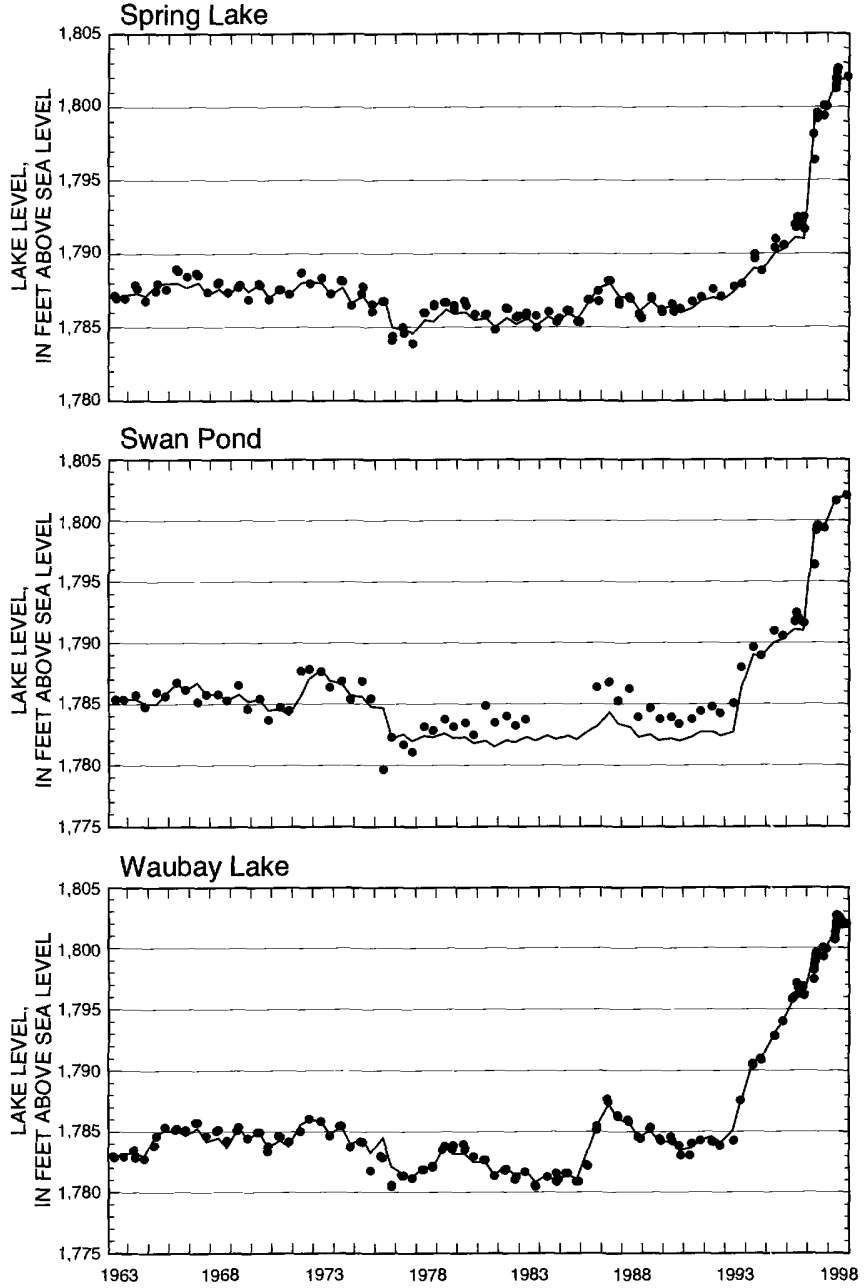

EXPLANATION

- SIMULATED

- HISTORIC

Figure 21. Simulated and historic lake levels of individual lakes within the Waubay Lakes Chain, 1963-98. 
Bitter Lake

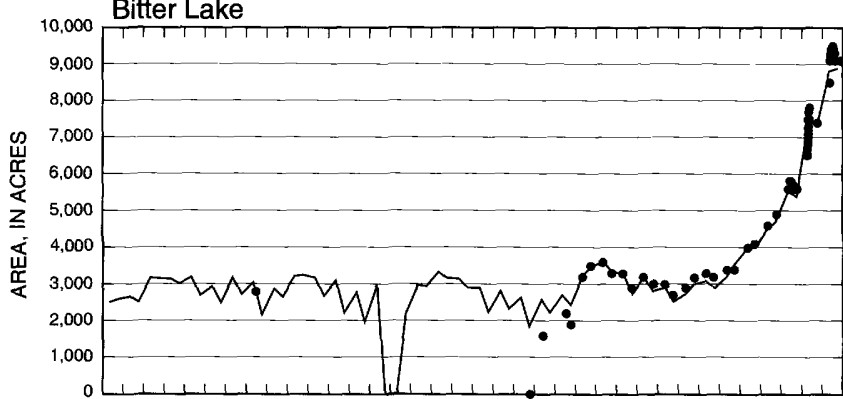

Blue Dog Lake
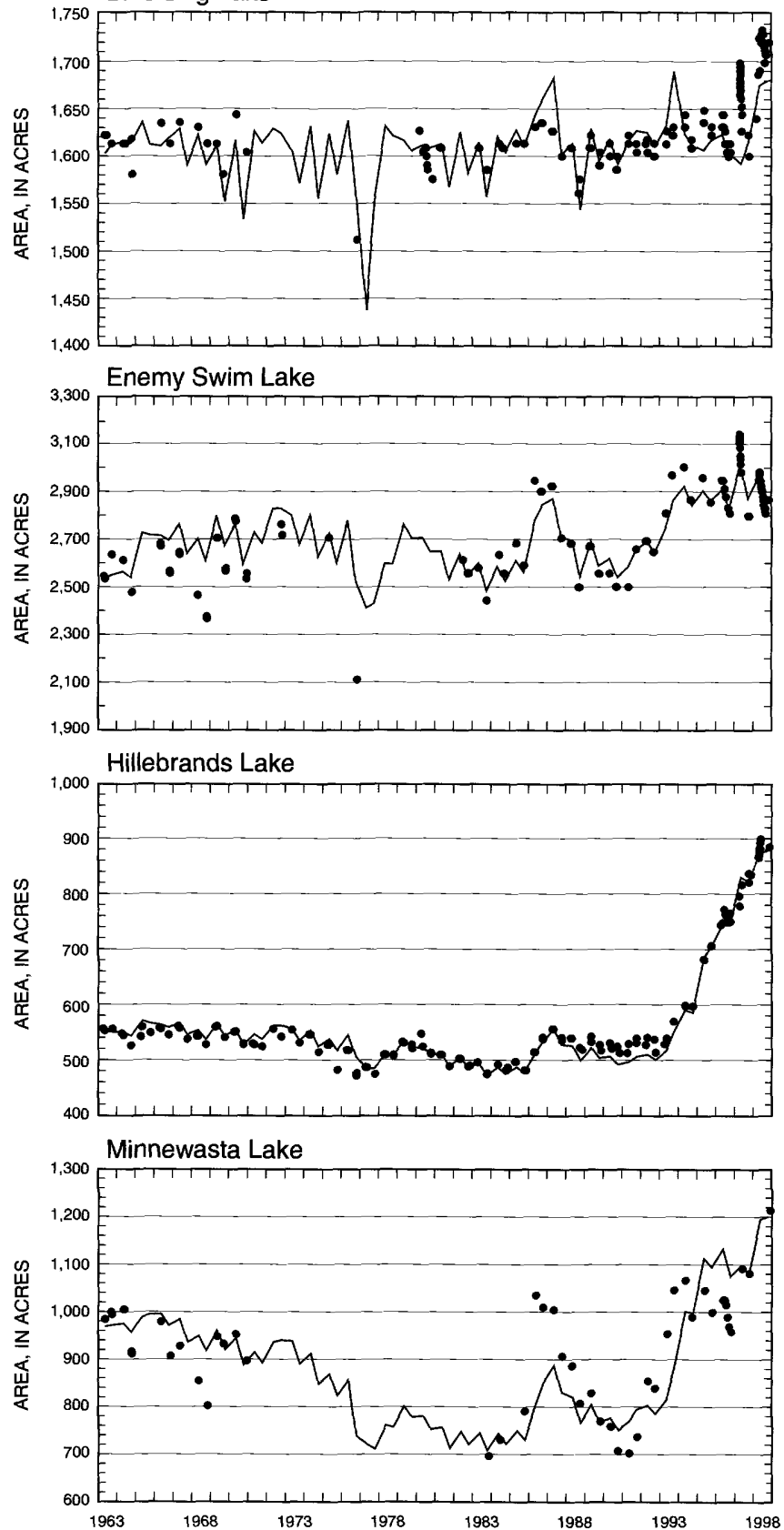

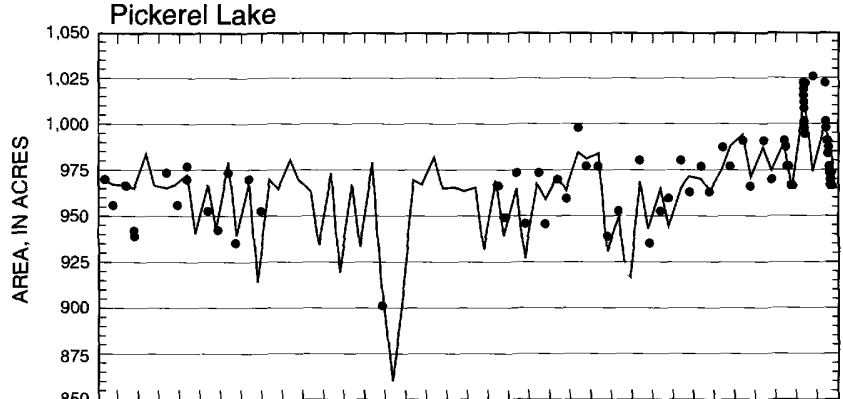

Rush Lake

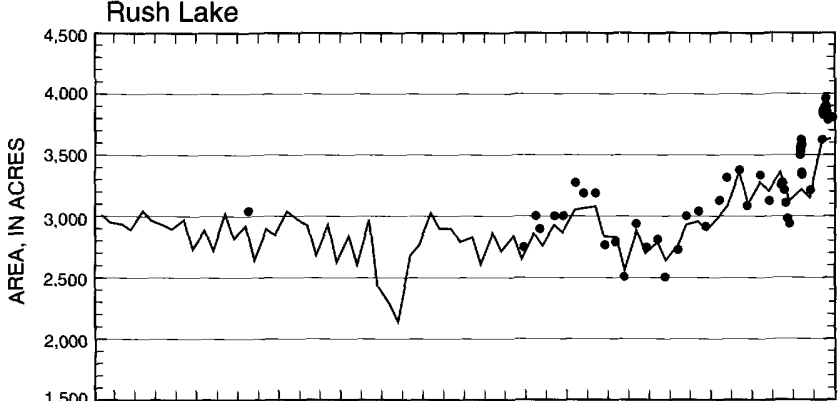

Spring Lake
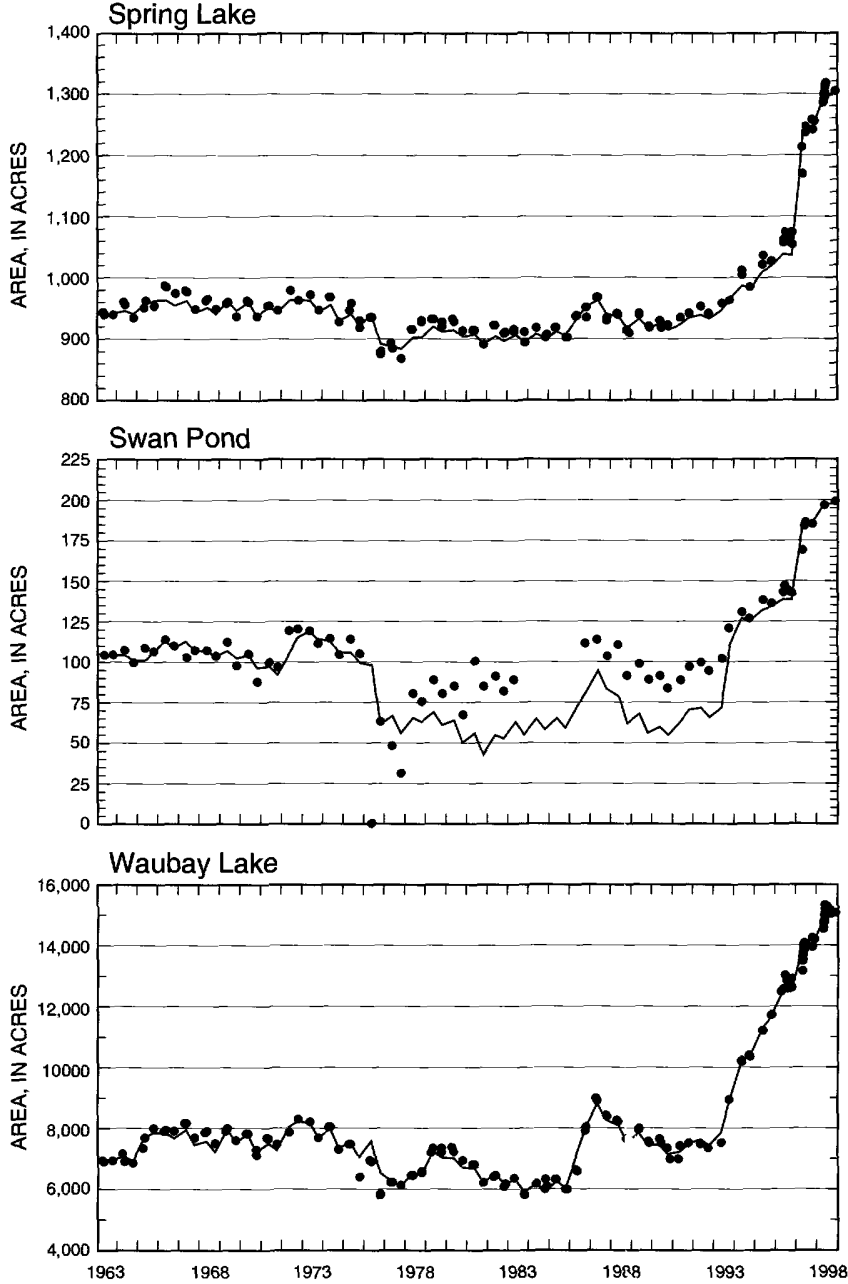

EXPLANATION
SIMULATED

- HISTORIC

Figure 22. Simulated and historic lake areas of individual lakes within the Waubay Lakes Chain, 1963-98. 

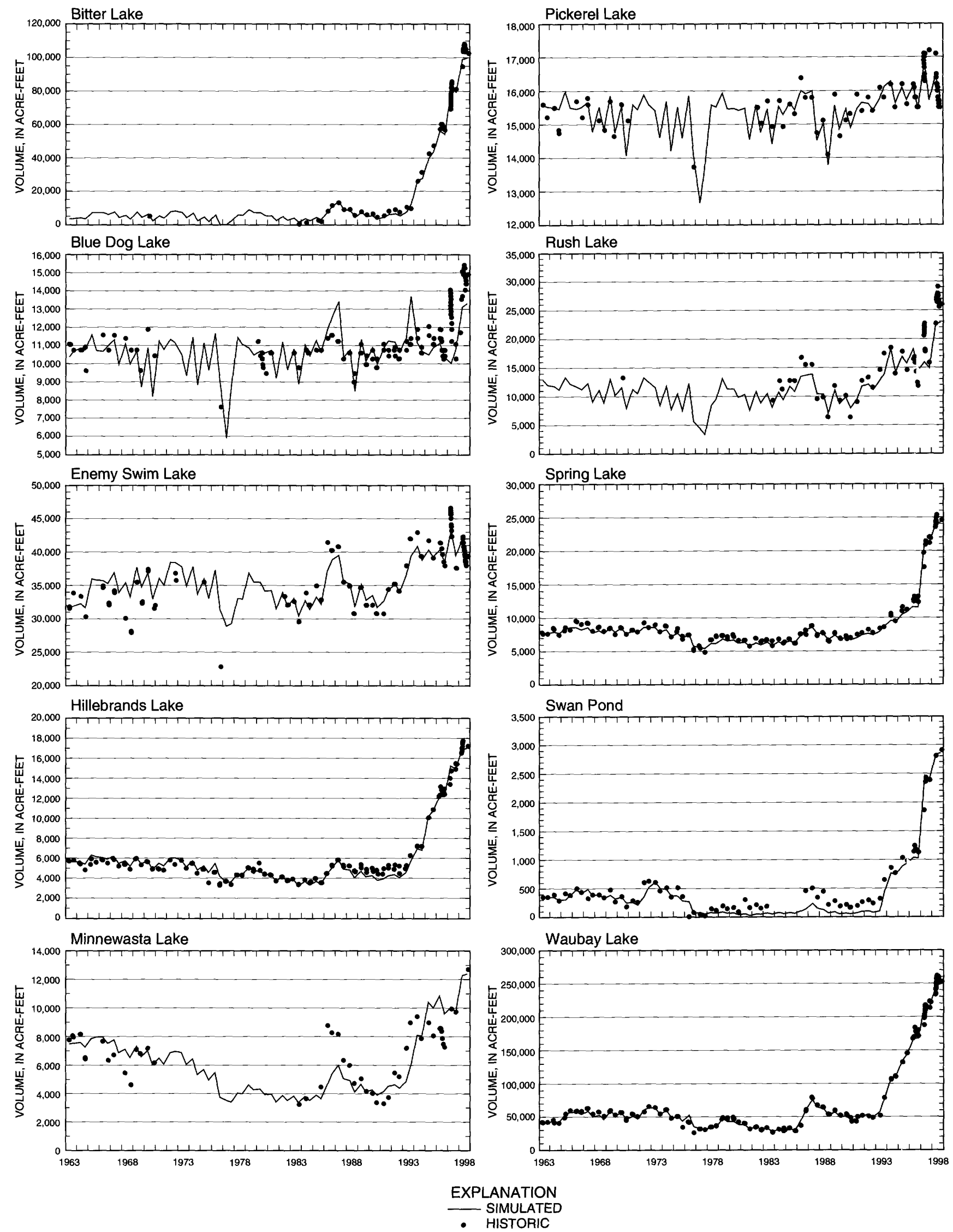

Fiqure 23. Simulated and historic lake volumes of individual lakes within the Waubav Lakes Chain, 1963-98. 

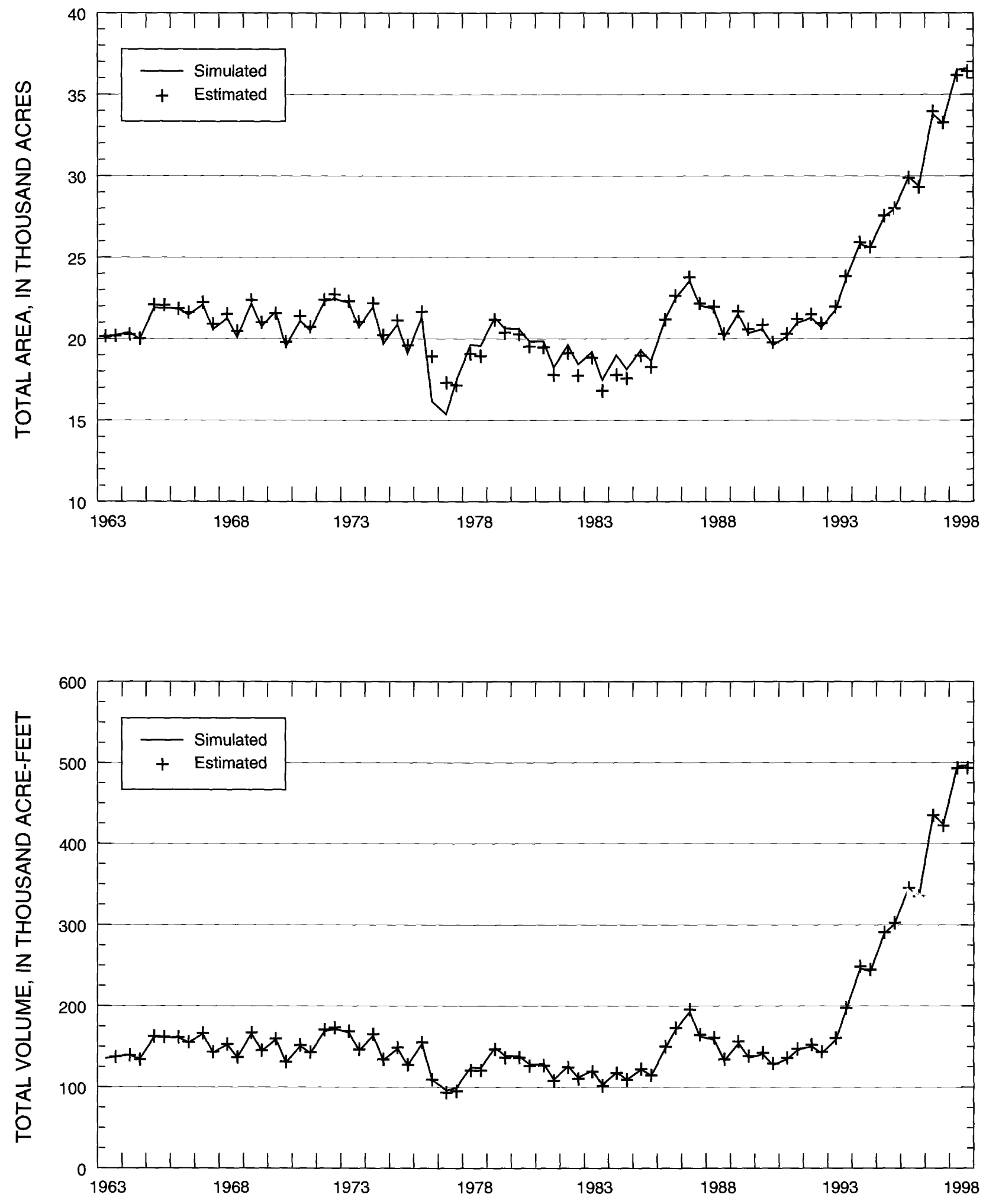

Figure 24. Simulated and estimated total area and volume of the Waubay Lakes Chain, 1963-98. 
The first step in the fitting procedure was to transform the historic data so that the transformed timeseries variables were closely approximated by a standard normal distribution. This was accomplished using Box-Cox transformations, as described in Wiche and Vecchia (1996). The resulting transformations are given in table 10.

The next step in the fitting procedure was to fit a multivariate, autoregressive time-series model to the transformed data. The model consists of a set of six simultaneous equations that relate each of the transformed time-series variables to lagged values of themselves and each other. The model requires that the data for all six variables be stacked in a one-dimensional array, in temporal order. The order in which the data are stacked in the array for a given time step can make a big difference in model performance. The best fit was achieved by placing evaporation data first, precipitation data second, and total inflow data last. The variable order is given in table 11 .

The model also requires that the set of potential predictor variables for each time-series variable be defined. Physically, precipitation and evaporation should not be causally related to total inflow. Also, although total inflow could be causally related to lagged values of itself, an adequate fit was obtaired using only precipitation and evaporation to predict inflow. Therefore, total inflow was not included as a predictor variable for either precipitation or evaporation, or itself. Next, maximum time lags of 1,2, and 3 years were considered for the potential predictor variables. The best fit was obtained using a maximum time lag of 2 years. Finally, to obtain a much better fit, separate terms, depending on whether the predictor variable was positive or negative, were allowed in the model. For example, the relation between winter total inflow (the time-series variable, $I W^{*}(t)$ ) and the previous summer evaporation (the predictor variable, $\left.E S^{*}(t-1)\right)$ is different depending on whether the previous summer evaporation is higher than normal (positive) or lower than normal (negative). The potential predictor variables included in the model are given in table 11.

Table 10. Normality transformations for winter and summer precipitation, evaporation, and total inflow [ln, natural logarithm]

\begin{tabular}{lll}
\hline \multicolumn{1}{c}{ Variable } & $\begin{array}{c}\text { Untransformed } \\
\text { data for year } t\end{array}$ & \multicolumn{1}{c}{ Transformed data for year t } \\
\hline Winter precipitation & $\mathrm{PW}(\mathrm{t})$ & $\mathrm{PW}^{*}(\mathrm{t})=\left\{[\mathrm{PW}(\mathrm{t})]^{0.7}-3.69\right\} / 0.87$ \\
Summer precipitation & $\mathrm{PS}(\mathrm{t})$ & $\mathrm{PS}^{*}(\mathrm{t})=\left\{[\mathrm{PS}(\mathrm{t})]^{0.4}-2.86\right\} / 0.31$ \\
Winter evaporation & $\mathrm{EW}(\mathrm{t})$ & $\mathrm{EW}^{*}(\mathrm{t})=\{\ln [\mathrm{EW}(\mathrm{t})-6]-1.0\} / 0.29$ \\
Summer evaporation & $\mathrm{ES}(\mathrm{t})$ & $\mathrm{ES}^{*}(\mathrm{t})=\{\ln [\mathrm{ES}(\mathrm{t})-16]-1.9\} / 0.37$ \\
Winter total inflow & $\mathrm{IW}(\mathrm{t})$ & $\mathrm{IW}^{*}(\mathrm{t})=\left\{[\mathrm{IW}(\mathrm{t})]^{0.4}-3.34\right\} / 1.06$ \\
Summer total inflow & $\mathrm{IS}(\mathrm{t})$ & $\mathrm{IS}^{*}(\mathrm{t})=\left\{[\mathrm{IS}(\mathrm{t})+5]^{0.3}-1.98\right\} / 0.47$ \\
\hline
\end{tabular}

Table 11. Variable order and potential predictor variables for multivariate, autoregressive time-series model for semiannual precipitation, evaporation, and total inflow

[t, time step; $\mathrm{k}$, time lag, in years; [.] $]^{+}$indicates that the quantity in brackets is replaced by zero if it is negative; [.] ' indicates that the quantity in brackets is replaced by zero if it is positive]

\begin{tabular}{|c|c|}
\hline Variable $^{1}$ & Potential predictor variables \\
\hline 1. $\mathrm{EW}^{*}(\mathrm{t})$ & $\begin{array}{l}{\left[\mathrm{EW}^{*}(\mathrm{t}-\mathrm{k})\right]^{+},[\mathrm{EW} *(\mathrm{t}-\mathrm{k})]^{-},[\mathrm{ES} *(\mathrm{t}-\mathrm{k})]^{+}, \text {and }[\mathrm{ES} *(\mathrm{t}-\mathrm{k})]^{-} ; \mathrm{k}=1 \text { or } 2} \\
{\left[\mathrm{PW}^{*}(\mathrm{t}-\mathrm{k})\right]^{+},\left[\mathrm{PW}^{*}(\mathrm{t}-\mathrm{k})\right]^{-},\left[\mathrm{PS}^{*}(\mathrm{t}-\mathrm{k})\right]^{+}, \text {and }[\mathrm{PS} *(\mathrm{t}-\mathrm{k})]^{-} ; \mathrm{k}=1 \text { or } 2}\end{array}$ \\
\hline 2. $P W *(t)$ & {$[\mathrm{EW} *(\mathrm{t})]^{+}$and $\left[\mathrm{EW}^{*}(\mathrm{t})\right]^{-}$in addition to predictor variables for $\mathrm{EW}^{*}(\mathrm{t})$} \\
\hline 3. $I W *(t)$ & {$\left[\mathrm{PW}^{*}(\mathrm{t})\right]^{+}$and $[\mathrm{PW} *(\mathrm{t})]^{-}$in addition to predictor variables for $\mathrm{PW} *(\mathrm{t})$} \\
\hline 4. $E S *(t)$ & Same predictor variables as for $I \mathrm{~W} *(\mathrm{t})$ \\
\hline 5. $\mathrm{PS} *(\mathrm{t})$ & {$\left[E S^{*}(t)\right]^{+}$and $\left[E S^{*}(t)\right]^{-}$in addition to predictor variables for $E S^{*}(t)$} \\
\hline 6. IS* $(\mathrm{t})$ & {$[\mathrm{PS} *(\mathrm{t})]^{+}$and $[\mathrm{PS} *(\mathrm{t})]^{-}$in addition to predictor variables for $\mathrm{PS} *(\mathrm{t})$} \\
\hline $\begin{array}{ll}{ }^{1} \text { Variables: } \\
\text { E, evaporation } \\
\text { P, precipitatio } \\
\text { W, winter } \\
\text { S, } & \text { summer }\end{array}$ & $\begin{array}{l}\text { I, total inflow } \\
t, \quad \text { time step } \\
*, \quad \text { indicates variable is transformed }\end{array}$ \\
\hline
\end{tabular}


The final model (table 12) was selected using allsubsets regression to determine the best combination of predictor variables from among the potential predictor variables. The $C_{p}$ statistic (Draper and Smith, 1981) was used to guard against over fitting, and residual plots and diagnostic tests were used to determine if the residuals (the differences between the actual and predicted values) from the fitted model were approximately normal and independently distributed. Normal probability plots indicated the residuals for each of the six variables were symmetrically distributed around zero, but slight deviations from a normal distribution were present for evaporation and total inflow; and pairwise scatter plots indicated the residuals for any given year were not independently distributed among the six variables. Therefore, to avoid potential problems with the assumption of normal and independently distributed residuals, an alternate method, called bootstrapping, was used to generate residuals in the time-series model. In the bootstrapping method, for each simulation year, a historic year was randomly selected from among historic water years 1963-98. The historic residuals for that year then were substituted for $\mathrm{X} 1, \ldots$, $\mathrm{X} 6$ in the equations given in table 12. A similar technique was used by Tasker (1997) to simulate inputs for a series of reservoirs in the northeastern United States. Some model verification results are presented in the next section in the comparison of historic and generated precipitation, evaporation, and total inflow data.

A detailed hydroclimatic explanation of the fitted time-series model given in table 12 would be difficult and is beyond the scope of this report. However, some facets of the model may be pertinent topics for future study. For example, the coefficients of determination $\left(R^{2}\right)$ are about 60 percent for winter evaporation, precipitation, and total inflow. The fact that these values are nearly identical is unusual. Also, these values are high given the generally unfredictable nature of evaporation and precipitation. Therefore, strong links may exist between winter atmospheric conditions and runoff and antecedent atmospheric conditions. However, the $R^{2}$ ( 16 percent) for summer precipitation is low, and the $R^{2}$ ( 48 percent) for summer total inflow is moderate although concurrent summer precipitation was included as a predictor variable. In contrast to the $R^{2}$ for summer precipitation, $R^{2}$ ( 98 percent) for summer evaporation is high and indicates a nearly deterministic relation between summer evaporation and antecedent evaporation. The high $R^{2}$ for summer evaporation may be causec. in part, by the method used to calculate winter evaporation as described in the task 1 report (Northern Great Plains Water Resources Research Center, written commun., July 1999). Because few pan evaporation records were available for the winter months, winter evaporation was calculated using estimated data rather than actual data. However, because historic total inflows were calculated from known lake-volume changes, the differences between the estimated and actual winter evaporation were taken into account.

Table 12. Final fitted time-series model for semiannual precipitation, evaporation, and total inflow

\begin{tabular}{|c|c|}
\hline Equation ${ }^{1}$ & $\begin{array}{l}\text { Coefficient of } \\
\text { determination } \\
\text { (percent) }\end{array}$ \\
\hline $\mathrm{PW}^{*}(\mathrm{t})=0.24+0.66\left[\mathrm{ES}^{*}(\mathrm{t}-1)\right]^{+}-0.82[\mathrm{PS} *(\mathrm{t}-1)]^{+}+0.65[\mathrm{PS} *(\mathrm{t}-1)]^{-}-0.97[\mathrm{EW} *(\mathrm{t}-1)]^{-}-0.57[\mathrm{PS} *(\mathrm{t}-2)]^{+}+0.69 \mathrm{X} 2(\mathrm{t})$ & 60 \\
\hline $\mathrm{IW}^{*}(\mathrm{t})=-0.14+0.96[\mathrm{ES} *(\mathrm{t}-1)]^{-}+0.46[\mathrm{PS} *(\mathrm{t}-1)]^{-}-1.64\left[\mathrm{EW}^{*}(\mathrm{t}-1)\right]^{-}+0.47[\mathrm{PW} *(\mathrm{t}-2)]^{+}+0.69 \mathrm{X} 3(\mathrm{t})$ & 59 \\
\hline $\mathrm{PS}^{*}(\mathrm{t})=-0.21+0.64\left[\mathrm{PW}^{*}(\mathrm{t})\right]^{+}+1.12\left[\mathrm{ES}^{*}(\mathrm{t}-2)\right]^{-}-0.91[\mathrm{EW} *(\mathrm{t}-2)]^{-}+0.92 \mathrm{X} 5(\mathrm{t})$ & 16 \\
\hline $\mathrm{IS}(\mathrm{t})=-0.97+0.93[\mathrm{PS} *(\mathrm{t})]^{+}-0.51\left[\mathrm{ES}^{*}(\mathrm{t}-1)\right]^{-}+0.57[\mathrm{EW} *(\mathrm{t}-1)]^{+}-0.56[\mathrm{ES} *(\mathrm{t}-2)]^{-}+0.79 \mathrm{X} 6(\mathrm{t})$ & 48 \\
\hline $\begin{array}{ll}{ }^{{ }^{1} \text { Equation: }} & \\
\text { E, evaporation } & \mathrm{I}, \quad \text { total inflow } \\
\mathrm{P}, \text { precipitation } & \mathrm{t}, \quad \text { time step } \\
\mathrm{W}, \text { winter } & * \text {, indicates variable is transformed } \\
\mathrm{S}, \text { summer } & \mathrm{X}, \text { model residual }\end{array}$ & \\
\hline
\end{tabular}




\section{Verification}

To obtain accurate estimates of the probability of future lake levels, the data generated from the timeseries model needed to accurately represent the statistical properties of actual precipitation, evaporation, and total inflow as reflected by the historic data. In this section, some comparisons are made between the historic and generated values of precipitation, evaporation, and total inflow data to help verify the model. To simplify the results, comparisons were made using annual data rather than semiannual data. The generated annual data were obtained by summing the generated winter and summer data for each year.

The stochastic time-series model was used to generate 10,000 years of annual precipitation, evaporation, and total inflow data (simulation 1) starting in water year 1999. Historic 1963-98 (water years) precipitation and evaporation data were used for the antecedent climatic conditions. The historic data and the first 122 years (water years 1999 to 2120) of generated data for simulation 1 are shown in figure 25 . For simulation 1, precipitation and evaporation data were generated using the time-series model given in table 12. Because the model was verified using historic 1963-98 data, simulation 1 is based on the assumption that 1963-98 is representative of long-term climatic conditions. For simulation 2, the precipitation and evaporation data generated for simulation 1 then were altered slightly by decreasing the precipitation data by 5 percent and increasing the evaporation data by 3 percent as also shown in figure 25. Simulation 2 is based on the assumption that the long-term climatic conditions are slightly drier than the historic 1963-98 climatic conditions. The generated total inflow data (using altered precipitation and evaporation data) for simulation 2 are slightly lower than those for simulation 1 because of the lower generated precipitation and higher generated evaporation data.

A cursory comparison of the historic and generated annual precipitation data shown in figure 25 indicates the historic data fit well with the generated data for both simulations, and both simulations have generated data that are higher than the historic maximum and lower than the historic minimum (the lower generated data occur after 2120). An advantage of generating data is that the generated data are not limited to the discrete set of values in the historic record. As shown later, the historic data are statistically indistinguishable from the generated data for both simulations.

The historic annual evaporation data shown in figure 25 also fit well with the generated data for both simulations, and both simulations have extremes outside of the range of historic data (generated data were curtailed at a maximum of 48 in. to prevent simulation of a few unrealistically large values). The generated data indicate a high degree of temporal persistence, with extended periods of low evaporation similar to those during 1993-98 and even longer periods of high evaporation similar to those during 1963-92.

The generated annual total inflow data shown in figure 25 fluctuate between a minimum of about zero and a maximum of about 135,000 acre-ft compared to the historic minimum of about zero in water year 1973 and the historic maximum of about 110,000 acre-ft in water year 1997. The historic data fit well with the generated data for both climatic simulations, and, as shown later, the historic data are statistically indistinguishable from the generated data for both simulations.

The stochastic model also reproduces the crosscorrelations between annual precipitation, evaporation, and total inflow as shown in figure 25. Periods of low (high) evaporation generally accompany periods of high (low) precipitation and high (low) inflow. The relations between historic and generated data for simulation 2 are shown in figure 26. To smooth out noise, the data were averaged for 3-year intervals for water years 1963 to 2148 . High annual precipitation and total inflow generally accompany low annual evaporation. However, although low annual precipitation and high annual evaporation limit the production of high inflow, in dry years, total inflow is only slightly sensitive to small changes in precipitation or evaporation.

A more quantitative assessment of the model can be made by comparing statistics of the historic data to statistics of the generated data (table 13). The lag-1 and lag-2 autocorrelations shown in table 13 are the correlations between values of the variable separated by 1 year and 2 years, respectively. Statistics of the historic and generated data should closely match for those statistics that have relatively small sampling errors with 36 years of historic data (for example, the mean, standard deviation, $50^{\text {th }}$ percentile, $25^{\text {th }}$ percentile, and $75^{\text {th }}$ percentile). However, statistics that are heavily affected by extremes (for example, the skewness coefficient, the minimum, and the maximum) have large sampling errors with 36 years of historic data. Therefore, the adequacy of the model for producing extremes that are representative of a long historic record is difficult to assess. More detailed information on using historic lake levels and climate, tree-ring chronologies, and soil surveys to better assess the adequacy of the model is given in a later section. 

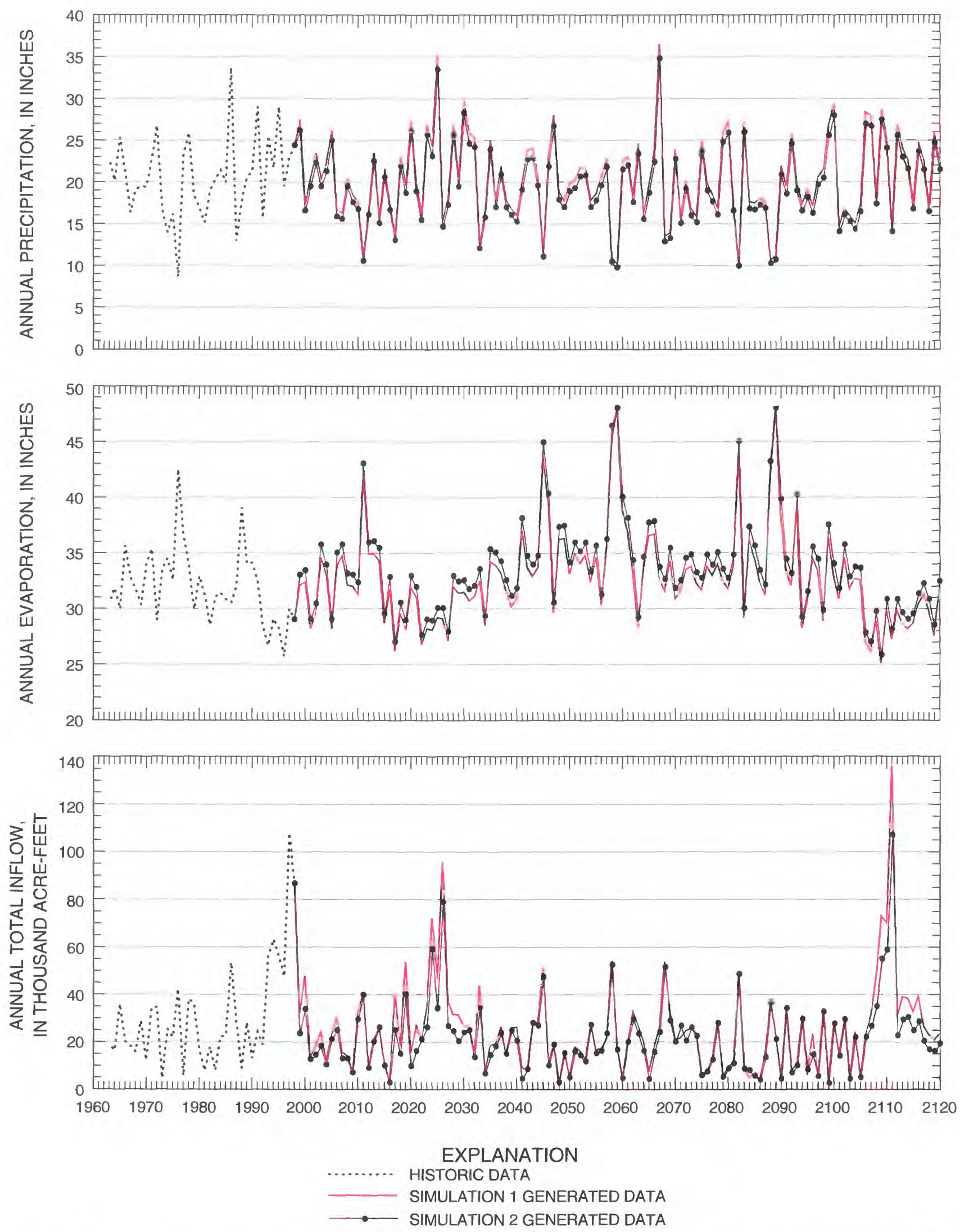

Figure 25. Historic (water years 1963-98) and generated (water years 1999-2120) annual precipitation, evaporation, and total inflow for the Waubay Lakes Chain. 

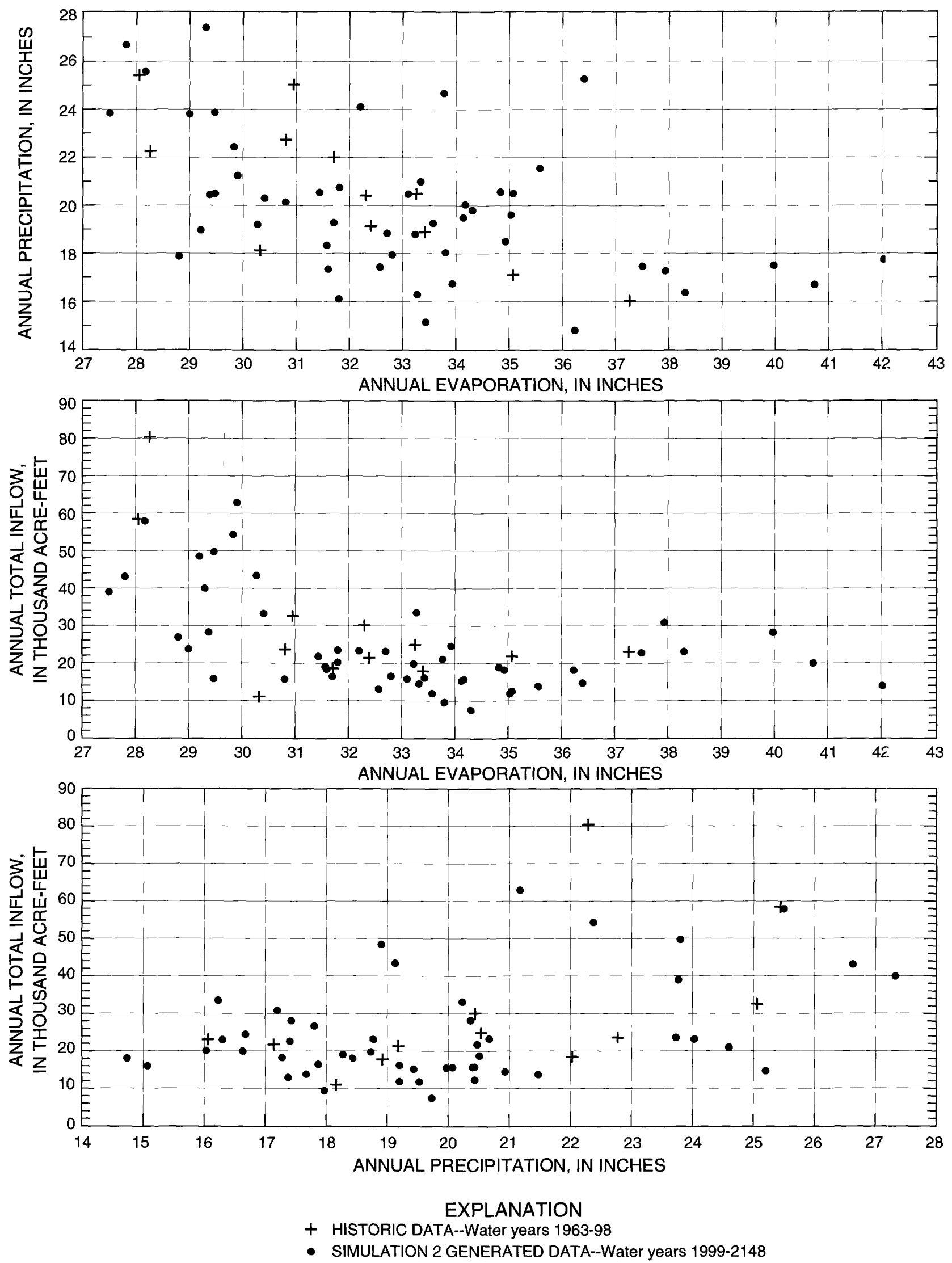

Figure 26. Historic and generated 3-year average annual evaporation versus precipitation, evaporation versus total inflow, and precipitation versus total inflow for the Waubay Lakes Chain. 


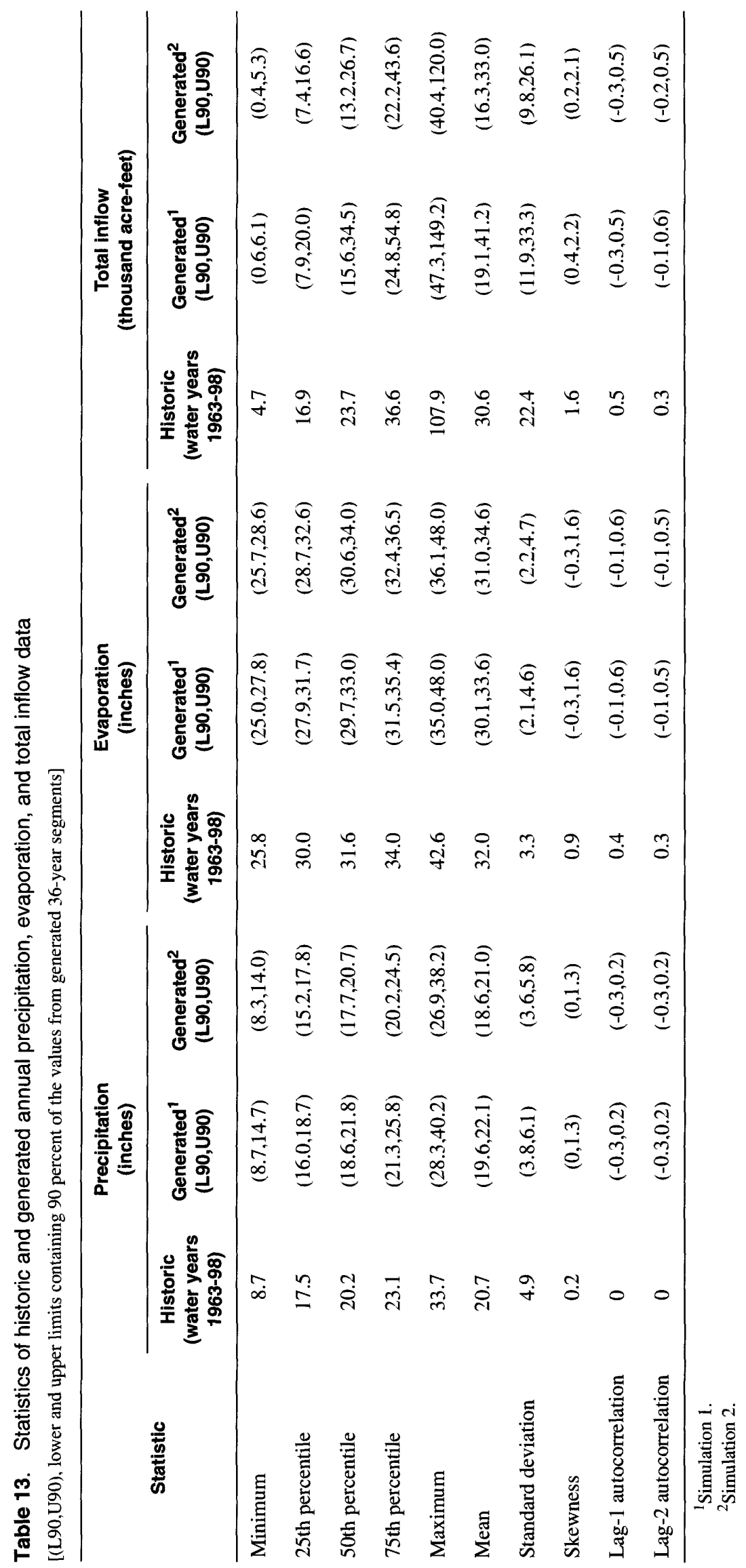

52 Lake-Level Frequency Analysis for the Waubay Lakes Chain, Northeastern South Dakota 
To compare statistics of the historic and generated data, the 10,000 years of generated data were divided into nonoverlapping 36-year segments. The statistics computed for each of the 36-year segments and the intervals (L90, U90) in which 90 percent of the generated statistics were contained ( 5 percent were below L90 and 5 percent were above U90) are given in table 13. The historic and generated statistics indicate the historic precipitation, evaporation, and total inflow data easily could have been produced by either simulation. For simulation 1 (wetter long-term climate), the historic statistics generally lie near the middle of the intervals; and, for simulation 2 (drier long-term climate), the historic statistics generally lie near the upper end of the intervals. For either simulation, the range of generated statistics is quite reasonable and the generated data are nicely representative of the "real-world" precipitation, evaporation, and total inflow data.

Although the generated precipitation and evaporation data for simulation 2 were obtained by simple scaling of the generated data for simulation 1 , the total inflow data were generated directly from the timeseries model for both simulations. The generated statistics of total inflow for the two simulations indicate the means, standard deviations, and percentiles of total inflow are reduced by about 15 percent from simulation 1 to simulation 2. Thus, total inflow is highly sensitive to small changes in climate because a 5-percent decrease in precipitation and a 3-percent increase in evaporation results in about a 15-percent decrease in total inflow.

\section{Verification Using Ancillary Information on Long-Term Historic Lake Levels}

Because total inflow to the Waubay Lakes Chain is highly sensitive to small changes in precipitation and evaporation, lake levels also are highly sensitive to small changes in precipitation and evaporation. In this section, information on historic lake levels and climate before water year 1963 is used to verify long-term lakelevel sequences generated from the stochastic timeseries model. Particularly, frequencies of extreme high or low lake levels generated from the model are verified from information on historic lake levels and climate, tree-ring chronologies, and soil surveys described in the reports for tasks 1 and 2 (Northern Great Plains Water Resources Research Center, written commun., July 1999) and for task 3 (South Dakota State University, written commun., June 1999).
Generated lake levels for each of the 10 major lakes of the Waubay Lakes Chain were obtained using 10,000 years of generated precipitation, evaporation, and total inflow data discussed earlier and shown in figure 25 (first 122 years only). The water massbalance model was used to generate semiannual lake volumes using the generated input data and October 1, 1998, starting lake levels. Part (water years 1999 to 2880) of the generated lake-level sequence for Waubay Lake is shown in figure 27 for simulation 1 (wetter long-term climate) and simulation 2 (drier long-term climate). To simplify the discussion, the maximum of the two semiannual lake levels for each year was used as the annual lake level.

As shown in figure 27, lake levels generated using simulation 1 generally are about 5 to $10 \mathrm{ft}$ higher than lake levels generated using simulation 2. Lake levels for simulation 1 are not comparable to historic water years 1963-92 lake levels for more than 800 years and are greater than an elevation of $1,780 \mathrm{ft}$ for the entire 10,000-year simulation period, but lake levels for simulation 2 are comparable to or lower than the historic water years 1963-92 lake levels several times in the first 800 years of the simulation period. Historic lake levels before water.year 1963 (fig. 10) indicate a period of extreme drought in the 1930's, during which Waubay Lake essentially was dry (elevation $1,773 \mathrm{ft}$ ). Tree-ring chronologies (task 3 report) from the study area indicate a period of extreme drought, similar to that in the 1930's, also occurred in the mid-1700's (South Dakota State University, written commun., June 1999). Therefore, simulation 2 produces extreme low lake levels similar in magnitude and frequency to long-term historic lake levels, and simulation 1 produces extreme low lake levels that have a much lower probability than indicated by historic evidence.

Tree-ring chronologies (task 3 ) also indicate the occurrence of five distinct wet periods during the 325 years from 1675 to 1999 , giving an average return period (time interval between events) of 65 years. These wet periods probably were strong enough to produce lake levels considerably higher than the levels during water years 1963-92 when the lake level of Waubay Lake fluctuated between elevations of 1,780 and $1,790 \mathrm{ft}$. The wet periods also were separated by distinct dry periods that probably were strong enough to reduce lake levels to below an elevation of $1,790 \mathrm{ft}$. The generated lake levels for Waubay Lake for simulation 2 indicate 92 distinct periods in 


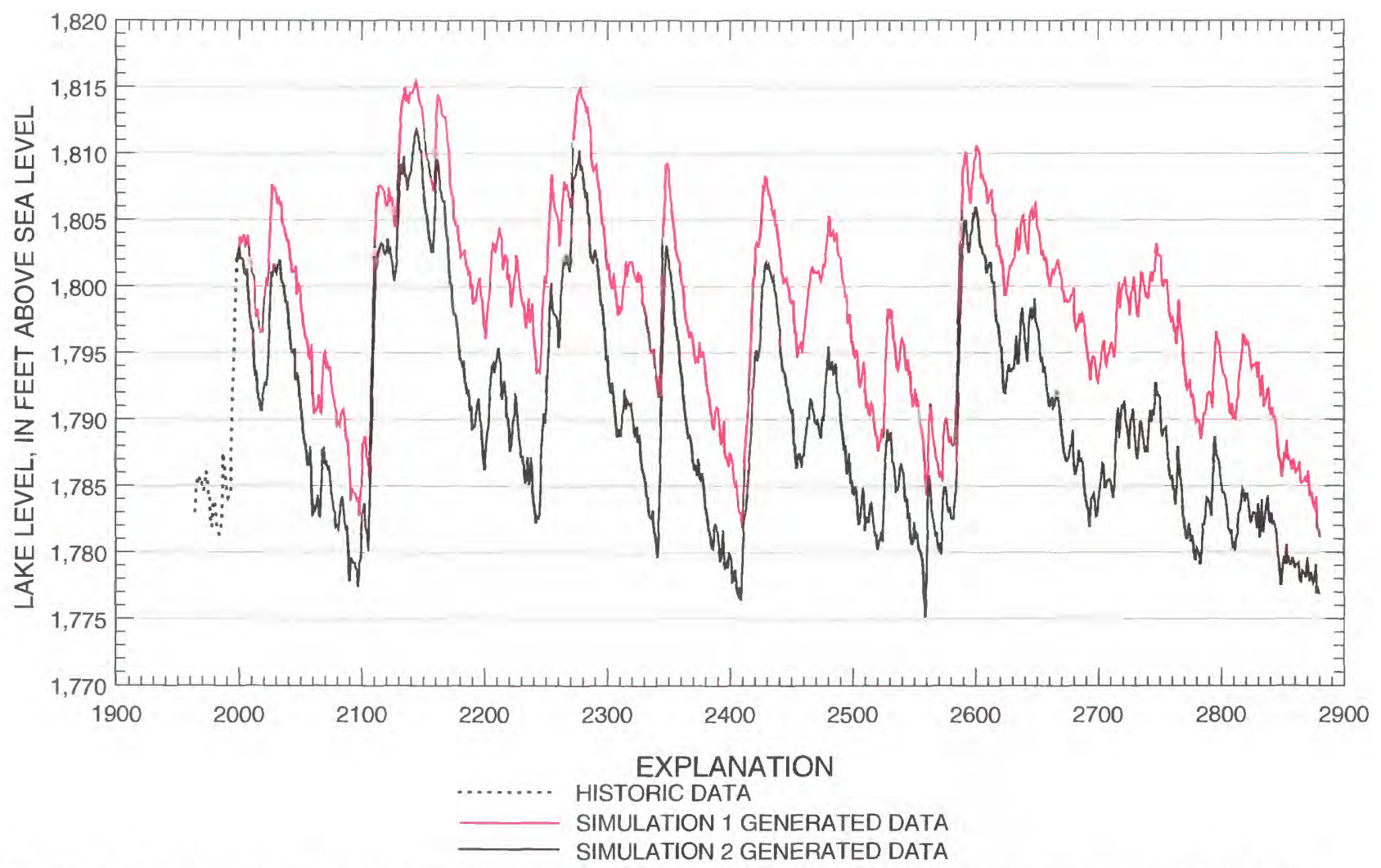

Figure 27. Historic (water years 1963-98) and generated (water years 1999-2880) annual maximum lake levels for Waubay Lake.

10,000 years, giving an average return period of 109 years during which lake levels exceeded an elevation of $1,790 \mathrm{ft}$. These periods were separated by distinct periods during which lake levels were below an elevation of 1,790 ft. For example, the lake levels shown in figure 27 for six distinct intervals for simulation 2 were below an elevation of $1,785 \mathrm{ft}$, rose above an elevation of $1,790 \mathrm{ft}$ for an extended period of time, and then were again below an elevation of $1,785 \mathrm{ft}$. In contrast, the lake levels for simulation 1 were above an elevation of $1,790 \mathrm{ft}$ for most of the simulation period.

Soil surveys in the study area (task 1) indicate the Waubay Lakes Chain probably has not spilled to the Big Sioux River, which has a spill elevation of about $1,811 \mathrm{ft}$, with any significant volume or duration since the glacial age (Northern Great Plains Water Resources Research Center, written commun., July 1999). The generated data indicate Waubay Lake was above an elevation of $1,811 \mathrm{ft} 13$ times in 10,000 years for simulation 2 (an average return period of 769 years) and 52 times in 10,000 years for simulation 1 (an average return period of 192 years). Furthermore, in many of the spills produced by simulation 1 , the lake level was several feet above an elevation of $1,811 \mathrm{ft}$ for many years, similar to the lake levels in the spills shown in figure 27. Most of the spills produced by simulation 2 were much less severe and shorter in duration than the spills produced by simulation 1 .

The comparisons between simulation 1 and simulation 2 indicate simulation 2 is much more representative of historic lake-level fluctuations than simulation 1. Thus, climate conditions during water years 1963-98 probably were wetter than normal when considered in the context of a much longer historic record. As discussed previously, the historic data, although for wetter-than-normal long-term average conditions assumed by simulation 2 , are well within the range of variability produced by simulation 2 . Therefore, although the possibility of a subtle climate change still may exist, the recent rise in the lake levels may be caused simply by natural climatic variability.

Because simulation 2 adequately reproduces long-term historic lake-level fluctuations and simulation 1 clearly is biased toward high lake levels, all frequency results presented later are based on the 
assumptions used to generate simulation 2. Thus, precipitation data generated by the stochastic time-series model are decreased by 5 percent and evaporation data are increased by 3 percent to correct for the apparent bias in the water year 1963-98 data used to verify the model.

\section{LAKE-LEVEL FREQUENCY ANALYSIS}

In this section, the frequencies of extreme high or low lake levels for the Waubay Lakes Chain are estimated using the stochastic time-series model to generate inputs for the water mass-balance model. As indicated previously, simulation 2 , in which the historic period of record (water years 1963-98) is assumed to have average precipitation 5 percent above the longterm average and average evaporation 3 percent below the long-term average, produces extreme lake levels in close agreement with historic evidence described in tasks 1 and 2 (Northern Great Plains Water Resources Research Center, written commun., July 1999) and in task 3 (South Dakota State University, written commun., June 1999). Therefore, the frequencies computed in this section are based on the assumptions of simulation 2. Furthermore, the frequencies are based on lake outlet elevations that existed in April 1999. Changes in outlet elevations, such as the proposed removal of the farm-crossing embankment between Rush and Bitter Lakes, will change the results of the frequency analysis.

Because lake levels of closed-basin lakes are characterized by high serial persistence, two methods need to be considered when performing a flood or drought frequency analysis. The first method, called unconditional frequency analysis, estimates the frequencies of high or low lake levels for a long time period during which the lake levels cycle many times between wet and dry periods. For example, 10,000 years of generated lake levels are used to compute unconditional frequencies for the Waubay Lakes Chain. The starting conditions at the beginning of the simulation period have no effect on the analysis because of the long simulation period. Unconditional frequency analysis is used to evaluate the frequency of an individual event, such as the historic lake-level rise for water years 1993-99, in the context of a much longer record.

The second method of frequency analysis, called conditional frequency analysis or position analysis, estimates the frequencies of future lake levels for a relatively short time period, such as 50 years. Berause of the short time period, the starting conditions at the beginning of the simulation period have an effect on the frequencies of the lake levels. For example, the Frobability of Bitter Lake spilling to the Big Sioux River sometime in the next 50 years is relatively high because of the much-higher-than-normal current lake level.

Thus, although, as shown later, the average time interval between natural spills to the Big Sioux $\mathrm{Ri}^{\text {rer }}$ is more than 1,000 years on the basis of unconditional frequency analysis, the probability of the lake spilling in the next 50 years is greater than 1 in 1,000. Because studies that relate to flood-risk-assessment or flondmitigation alternatives usually are pertinent only for relatively short time periods into the future, conditional frequency analysis usually is more appropriate than unconditional frequency analysis.

\section{Unconditional Frequency Analysis}

Unconditional frequency analysis was performed for Bitter, Enemy Swim, Pickerel, and Wcubay Lakes using the 10,000 years of generated lake levels described previously (simulation 2). The generated data for Waubay Lake are shown in figure 28. To smooth some of the high-frequency variation in the data, the maximum lake levels for successive 20-year intervals are shown in the figure. Also shown is the (unconditional) 1-percent exceedance level, which is defined as the lake level above which 1 percent $c^{f}$ the annual maximum lake levels lie. For Waubay Lake, the 1-percent exceedance level is at an elevation of $1,811.5 \mathrm{ft}$, which is approximately equal to the closedbasin spill elevation to the Big Sioux River. However, only 13 separate spill events occurred during the 10,000-year simulation period, giving an average. return period of 769 years. If the lake levels were independent from year-to-year (as usually is the case when considering annual stream discharges), the recurrence interval for the 1-percent exceedance level would be 1 divided by the exceedance probability, or 100 years. However, because of the high serial persistence in the lake levels, the return period corresponding to the 1-percent exceedance level is much longer than 100 years. The average duration of each event is the number of years the lake level is above an elevation of $1,811.5 \mathrm{ft}$ (100) divided by the number of occurrences (13). Thus, the lake level is above an elevation $c^{f}$ $1,811.5 \mathrm{ft}$ an average of every 769 years but stay? above that level an average of 8 years per event. 


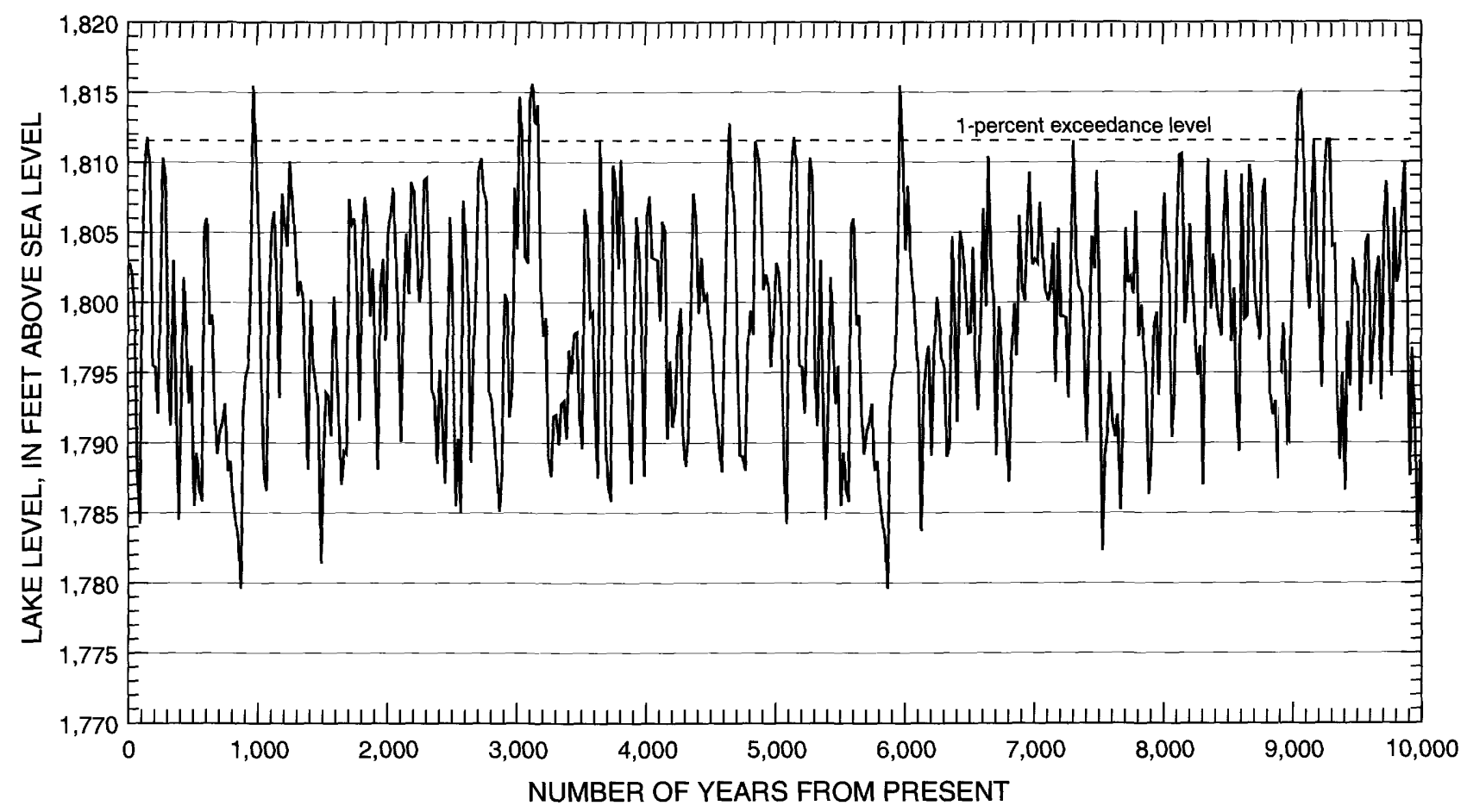

Figure 28. Generated 20-year maximum lake levels for Waubay Lake for simulation 2 using an unconditicnal frequency analysis.

The exceedance levels, average return periods, and average durations for selected exceedance probabilities for Bitter, Enemy Swim, Pickerel, and Waubay Lakes are shown in table 14. The values for the remaining six lakes are identical to those for Waubay Lake because Swan Pond and Blue Dog, Hillebrands, Minnewasta, Rush, and Spring Lakes are joined with Waubay Lake above an elevation of $1,800.2 \mathrm{ft}$ (fig. 2). On April 4, 1999, Bitter Lake was at an elevation of $1,791.5 \mathrm{ft}$, Enemy Swim Lake was at an elevation of 1,854.1 ft, Pickerel Lake was at an elevation of $1,845.7 \mathrm{ft}$, and Waubay Lake was at an elevation of $1,802.9 \mathrm{ft}$ (table B1 of the Supplemental Information section). These values are all near the 10 -percent exceedance probability (table 14). However, the average return periods are much higher than 10 years (227 years for Bitter Lake, 50 years for Enemy Swim Lake, 30 years for Pickerel Lake, and 119 years for Waubay Lake), and the average durations are longer than 1 year (23 years for Bitter Lake, 5 years for Enemy Swim Lake, 3 years for Pickerel Lake, and 12 years for Waubay Lake). Generally, the smaller upstream lakes, such as Pickerel and Enemy Swim Lakes, are more sensitive to short-term climatic fluctuations than the larger downstream lakes, such as Bitter and Waubay Lakes. Therefore, Enemy Swim and Pickerel Lakes generally reach levels similar to those in
1999 more often than Bitter and Waubay Lakes and stay at those levels for shorter time periods.

The lake levels for the 1-percent exceedance probabilities in table 14 are about $19 \mathrm{ft}$ higher for Bitter Lake, $1.2 \mathrm{ft}$ higher for Enemy Swim Lake, $0.7 \mathrm{ft}$ higher for Pickerel Lake, and $8.6 \mathrm{ft}$ higher for Waubay Lake than the levels of those lakes on April 4, 1999. However, the average return periods are 909 years for Bitter Lake, 185 years for Enemy Swim Lake, 155 years for Pickerel Lake, and 769 years for Waubay Lake. For example, if in the next several years Bitter Lake continues to rise to an elevation of $1,810.2 \mathrm{ft}$, an event that happens only once in an average of $90 \%$ years would occur. If Bitter Lake does rise to an elevation of $1,810.2 \mathrm{ft}$, it could stay above that level for 9 years or longer before beginning to subside.

The average return periods for Enomy Swim and Pickerel Lakes for the 0.2-percent excesdance probabilities in table 14 are 500 years, indicat ing the extreme high lake levels of the smaller upstream lakes probably are caused by 1-year climatic extremes. However, the average return periods for Bitter and Waubay Lakes for the 0.2-percent exceedance probabilitie are 2,000 years, indicating the extreme high lake levels of the larger downstream lakes probably are caused by extreme climatic conditions lasting sevaral years. 
Table 14. Probability of high lake levels using an unconditional frequency analysis for the Waubay Lakes Chain based on simulation 2

\begin{tabular}{|c|c|c|c|c|}
\hline Lake & $\begin{array}{c}\text { Exceedance } \\
\text { probability }{ }^{1} \\
\text { (percent) }\end{array}$ & $\begin{array}{c}\text { Exceedance } \\
\text { level } \\
\text { (feet above } \\
\text { sea level) }\end{array}$ & $\begin{array}{l}\text { Average return } \\
\text { period }^{2} \\
\text { (years) }^{\text {(year }}\end{array}$ & $\begin{array}{c}\text { Average } \\
\text { duration }^{3} \\
\text { (years) }\end{array}$ \\
\hline \multirow[t]{6}{*}{ Bitter } & $10(1$ in 10$)$ & $1,796.8$ & 227 & 23 \\
\hline & $4(1$ in 25$)$ & $1,805.0$ & 357 & 14 \\
\hline & $2(1$ in 50$)$ & $1,808.2$ & 667 & 13 \\
\hline & $1(1$ in 100$)$ & $1,810.2$ & 909 & 9 \\
\hline & $0.5(1$ in 200$)$ & $1,812.7$ & 1,430 & 7 \\
\hline & $0.2(1$ in 500$)$ & 1.814 .4 & 2,000 & 4 \\
\hline \multirow[t]{6}{*}{ Enemy Swim } & $10(1$ in 10$)$ & $1,854.0$ & 50 & 5 \\
\hline & $4(1$ in 25$)$ & $1,854.5$ & 71 & 3 \\
\hline & $2(1$ in 50$)$ & $1,854.9$ & 116 & 2 \\
\hline & $1(1$ in 100$)$ & $1,855.3$ & 185 & 2 \\
\hline & $0.5(1$ in 200$)$ & 1.855 .7 & 312 & 2 \\
\hline & $0.2(1$ in 500$)$ & $1,856.1$ & 500 & 1 \\
\hline \multirow[t]{6}{*}{ Pickerel } & $10(1$ in 10$)$ & $1,845.6$ & 30 & 3 \\
\hline & $4(1$ in 25$)$ & $1,845.9$ & 55 & 2 \\
\hline & $2(1$ in 50$)$ & $1,846.1$ & 83 & 2 \\
\hline & $1(1$ in 100$)$ & $1,846.4$ & 155 & 2 \\
\hline & $0.5(1$ in 200$)$ & $1,846.6$ & 244 & 1 \\
\hline & $0.2(1$ in 500$)$ & $1,846.7$ & 500 & 1 \\
\hline \multirow[t]{6}{*}{ Waubay } & $10(1$ in 10$)$ & $1,804.4$ & 119 & 12 \\
\hline & $4(1$ in 25$)$ & $1,808.1$ & 238 & 10 \\
\hline & $2(1$ in 50$)$ & $1,810.0$ & 385 & 8 \\
\hline & $1(1$ in 100$)$ & $1,811.5$ & 769 & 8 \\
\hline & $0.5(1$ in 200$)$ & $1,812.7$ & 1,430 & 7 \\
\hline & $0.2(1$ in 500$)$ & $1,814.4$ & 2,000 & 4 \\
\hline
\end{tabular}

${ }^{1}$ Percent of time the lake is above a given level.

${ }^{2}$ Average time between events when the lake is above a given level.

${ }^{3}$ Average time per event that the lake is above a given level. 
Results from the unconditional frequency analysis for low lake levels are given in table 15, and historic low lake levels for the lakes are shown in figure 10. The annual maximum lake levels generated for simulation 2 were reduced by $2 \mathrm{ft}$ because, in dry years, lake levels usually are about $2 \mathrm{ft}$ lower at the end of the summer than peak lake levels following spring runoff.

The frequencies for extreme low lake levels are difficult to accurately determine because small changes in lake volumes result in large changes in lake levels. For example, as shown in figure 18 , the volume of Bitter Lake at an elevation of $1,775 \mathrm{ft}$ differs only slightly from the volume at an elevation of $1,770 \mathrm{ft}$ (essentially dry). Likewise, the volume of Waubay Lake at an elevation of $1,780 \mathrm{ft}$ differs only slightly from the volume at an elevation of $1,77 \approx \mathrm{ft}$ (essentially dry). Therefore, the very small exceed $\varepsilon$ nce probabilities ( 0.5 and 0.2 percent) are not given in table 15 . However, as indicated in table 15 and figure 10, the lake levels of Enemy Swim, Pickerel, and Waubay Lakes in the 1930's and 1940's were very low compared to the long-term lake levels. For example, for 12 years in the 1930's, Enemy Swim Lake was below an elevation of $1,845 \mathrm{ft}$, which corresponds to a return period of about 300 years in table 15 . Similarly, for 4 years in the 1930's, Pickerel Lake was below an elevation of $1,842 \mathrm{ft}$, which corresponds to a return period of about 125 years, and for about 10 years in the 1930's, Waubay Lake was below an elevation of $1,780 \mathrm{ft}$, which corresponds to a return feriod of 227 years.

Table 15. Probability of low lake levels using an unconditional frequency analysis for the Waubay Lakes Chä in based on simulation 2

\begin{tabular}{lcccc}
\hline Lake & $\begin{array}{c}\text { Non-exceedance } \\
\text { probability } \\
\text { (percent) }\end{array}$ & $\begin{array}{c}\text { Exceedance } \\
\text { level } \\
\text { (feet above } \\
\text { sea level) }\end{array}$ & $\begin{array}{c}\text { Average return } \\
\text { period }^{2} \\
\text { (years) }\end{array}$ & $\begin{array}{c}\text { Average } \\
\text { duration }^{3} \\
\text { (years) }\end{array}$ \\
\hline Bitter & $10(1$ in 10) & $1,777.2$ & 112 & 8 \\
& $4(1$ in 25) & $1,775.6$ & 526 & 11 \\
Enemy Swim & $2(1$ in 50) & $1,774.3$ & 769 & 8 \\
& $1(1$ in 100) & $1,773.4$ & 70 & 7 \\
Pickerel & $10(1$ in 10) & $1,846.9$ & 182 & 6 \\
& $4(1$ in 25) & $1,845.7$ & 294 & 5 \\
Waubay & $2(1$ in 50) & $1,844.8$ & 476 & 3 \\
& $1(1$ in 100) & $1,844.1$ & 27 & 2 \\
& $10(1$ in 10) & & 40 & 1 \\
\hline & $4(1$ in 25) & $1,842.9$ & 67 & 1 \\
\hline
\end{tabular}

${ }^{1}$ Percent of time the lake is below a given level.

${ }^{2}$ Average time between events when the lake is below a given level.

${ }^{3}$ Average time per event that the lake is below a given level. 


\section{Conditional Frequency Analysis Starting from Present Conditions}

A conditional frequency analysis was performed for the 10 major lakes of the Waubay Lakes Chain using 10,000 simulated 50-year lake-level traces, each starting on October 1, 1998. The generated data can be used to estimate the probability of virtually any event that involves future lake levels. For example, the probability that Waubay Lake will rise an additional $5 \mathrm{ft}$ in the next 10 years or the probability that it will fall $10 \mathrm{ft}$ in the next 10 years can be computed (table B10 of the Supplemental Information section). The probability that Waubay Lake will exceed a given lake level in any specific year in the future or, conversely, the lake level in any given year that has a specified exceedance probability also can be computed.

The historic data for Waubay Lake are shown in figure 29 along with five traces of generated future lake levels. Also shown are the upper and lower 1-percent probability bounds on future (water years 1999 to 2048) lake levels. For any given year, 1 percent of the traces (100 traces out of 10,000) are above the upper 1 -percent probability bound, and 1 percent of the traces are below the lower 1-percent probability bound. The effect of the high lake level at the end of the historic period is evident in the future traces. The traces generally are tightly grouped at the beginning of the simulation period before eventually diverging. The upper 1-percent probability bound rises quickly to a constant level of an elevation of $1,811.5 \mathrm{ft}$, which corresponds to the unconditional 1-percent exceedance level discussed previously (table 14). Therefore, the chance that Waubay Lake will continue to rise to the spill elevation with the Big Sioux River within the next 20 years is relatively high (greater than 1 percent). The lower 1-percent probability bound falls slowly during the next 50 years and reaches the unconditional lower 1-percent exceedance level well beyond 2048. Thus, Waubay Lake is unlikely to return to levels comparable to historic 1960-92 levels for at least 40 years. Also, Waubay Lake is unlikely to return to levels comparable to those during the extreme drought of the 1930's for much longer than 50 years.

The 0.2-percent, 1-percent, and 10-percent upper and lower probability bounds for the 10 major lakes are shown in figures 30 through 39 . The 1-percent probability bounds shown in figure 39 for Waubay Lake are the same as those shown in figure 29.

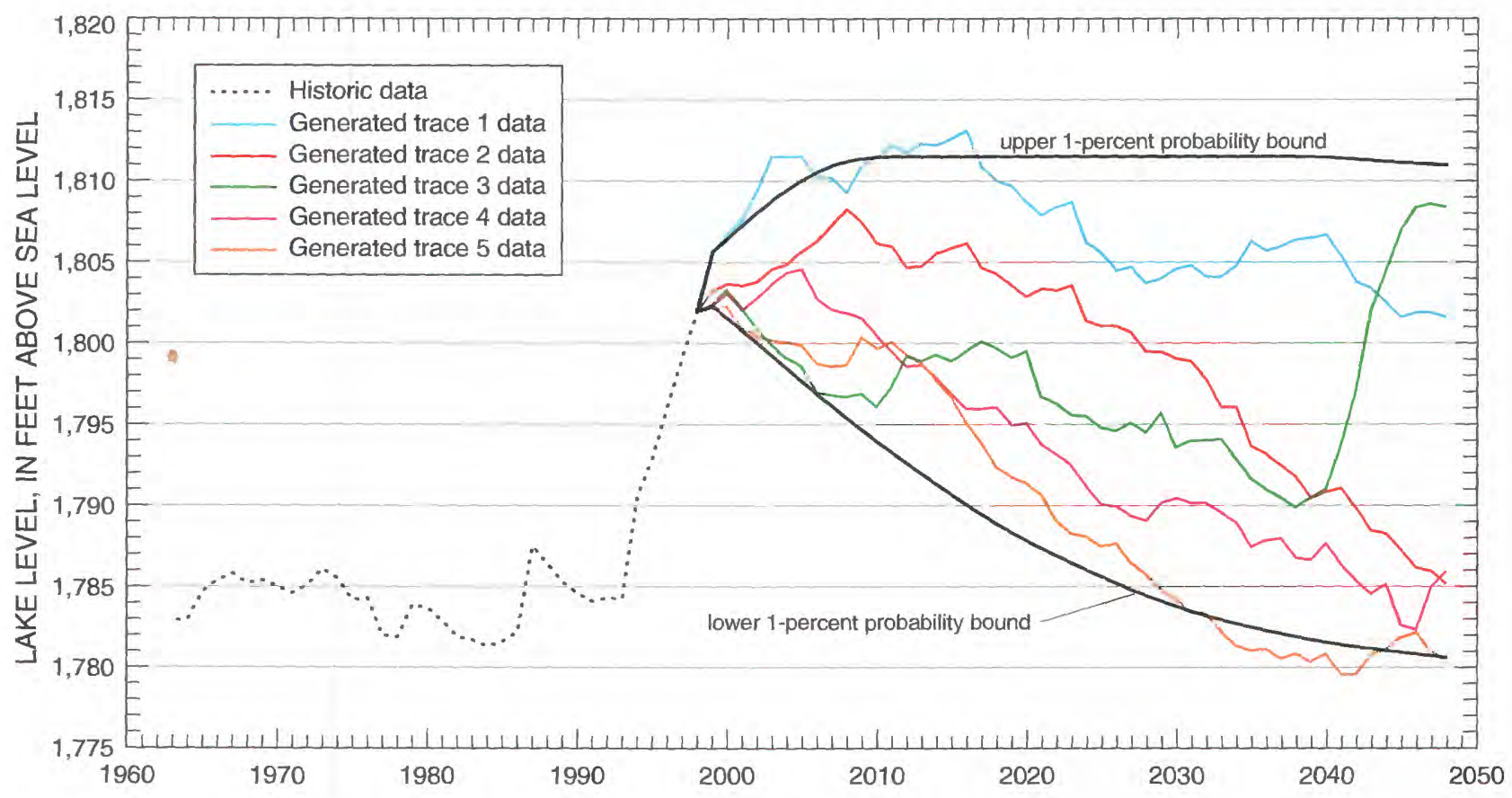

Figure 29. Historic (water years 1963-98) and generated (water years 1999-2048) annual maximum lake levels for Waubay Lake. 


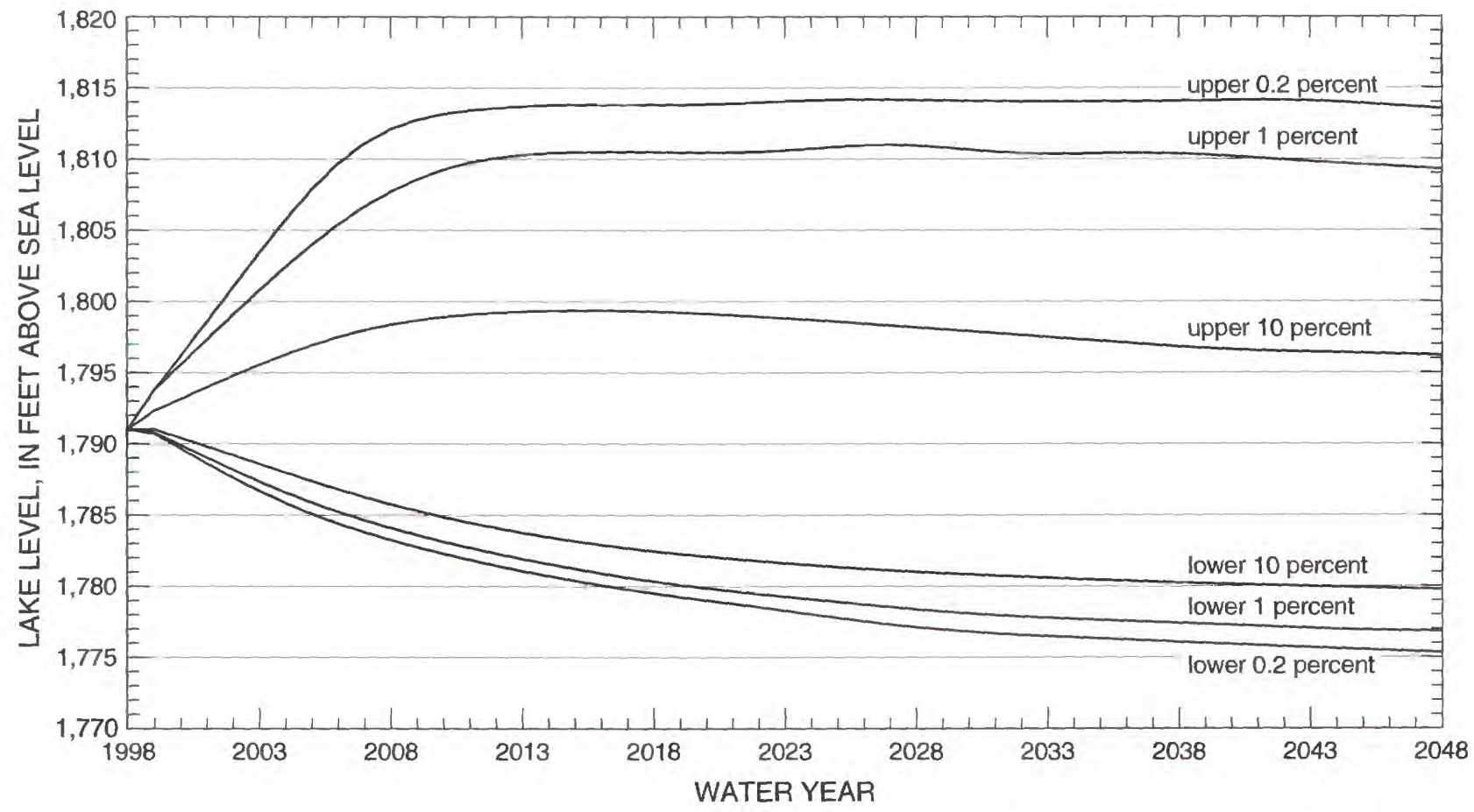

Figure 30. Upper and lower probability bounds for Bitter Lake computed from 10,000 50-year traces from the water mass-balance model, with each trace starting October 1, 1998.

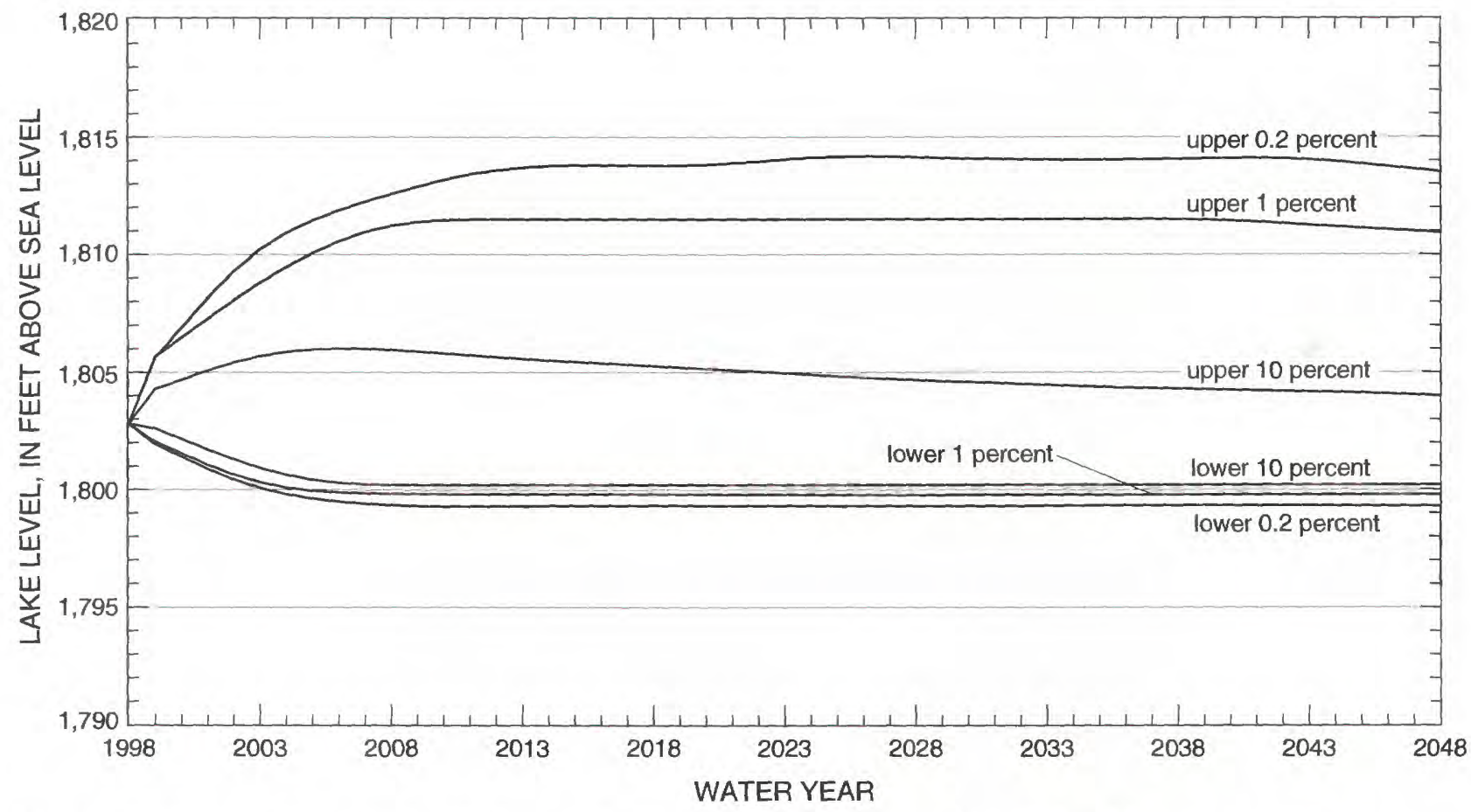

Figure 31. Upper and lower probability bounds for Blue Dog Lake computed from 10,000 50-year traces from the water mass-balance model, with each trace starting October 1, 1998. 


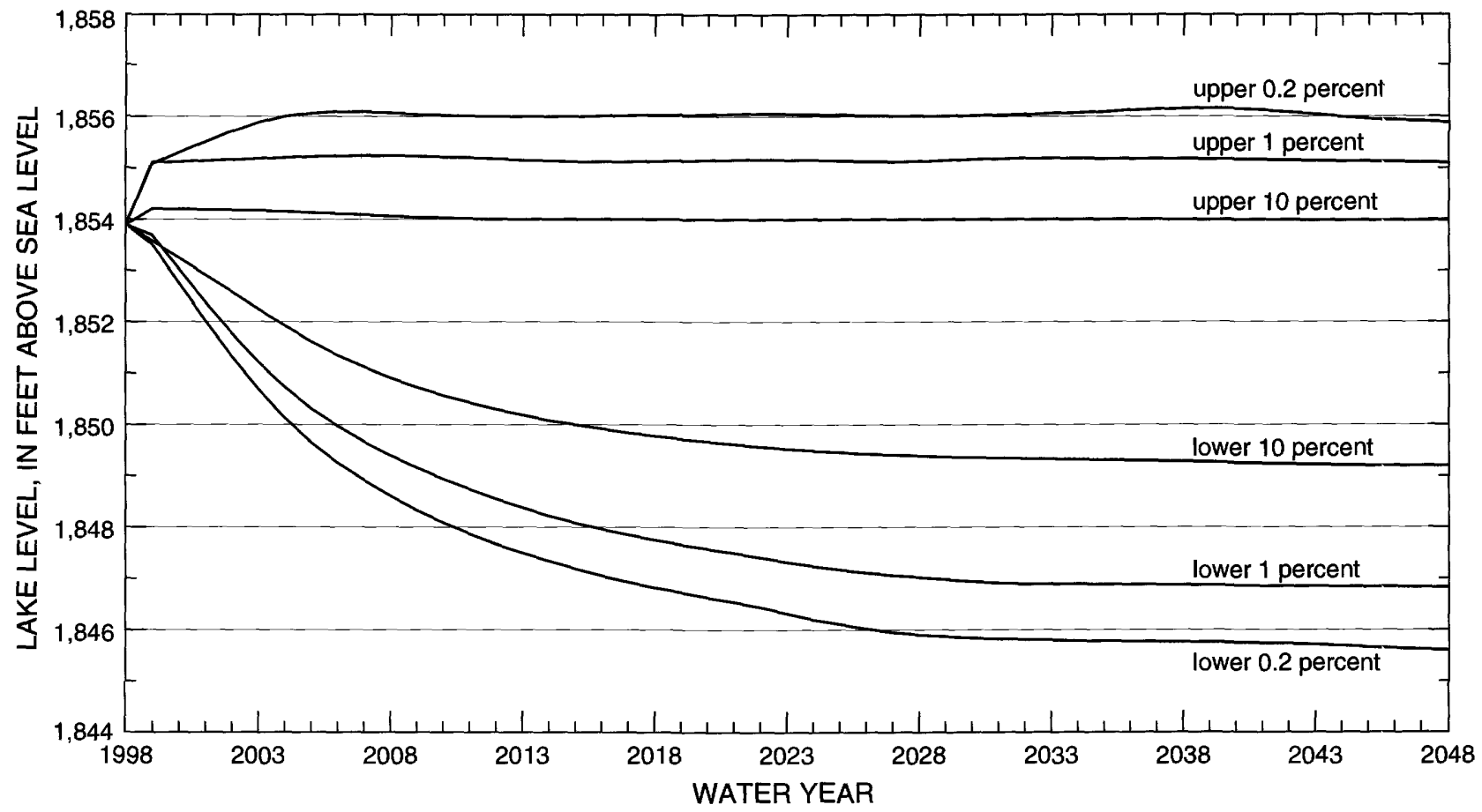

Figure 32. Upper and lower probability bounds for Enemy Swim Lake computed from 10,000 50-year traces from the water mass-balance model, with each trace starting October 1, 1998.

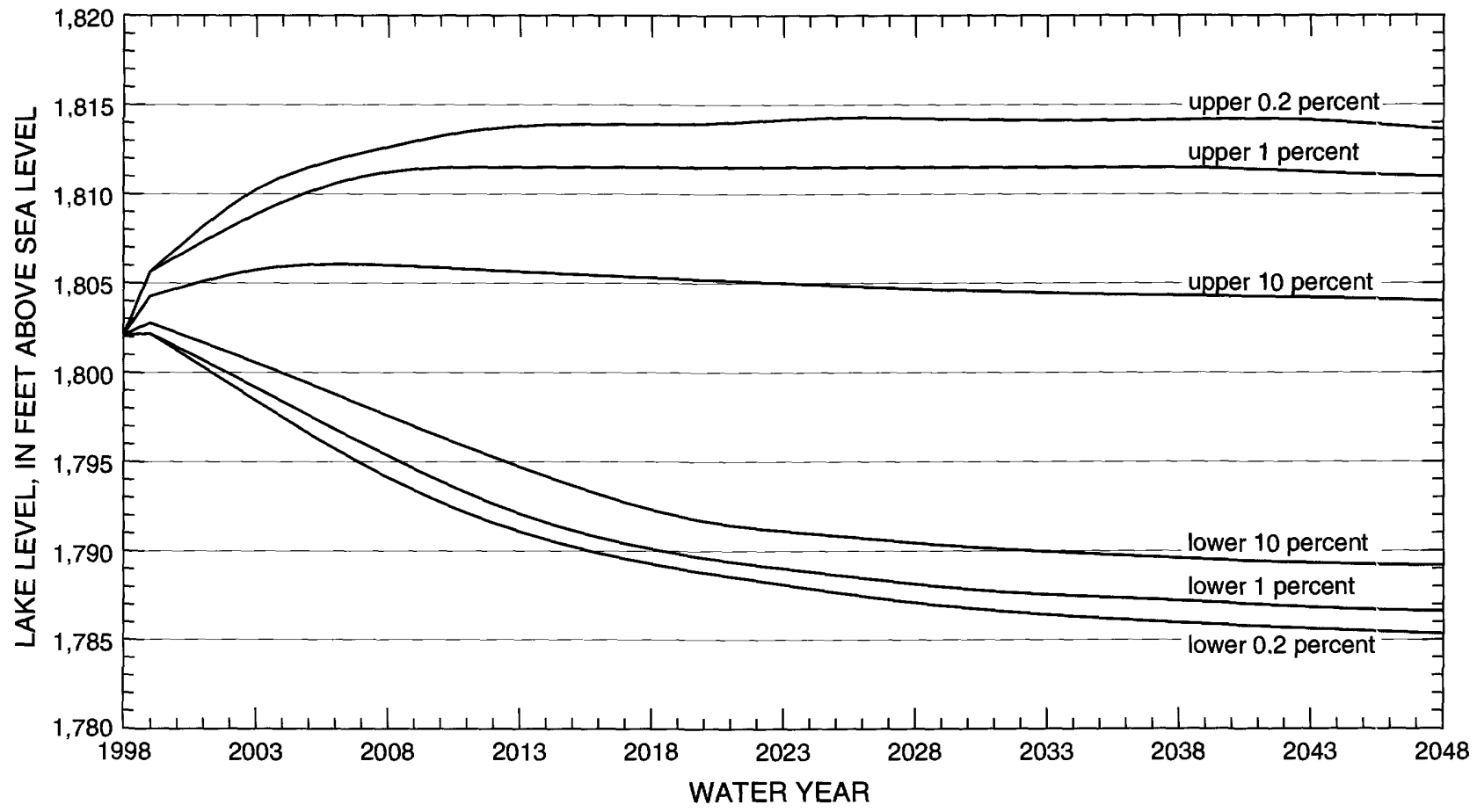

Figure 33. Upper and lower probability bounds for Hillebrands Lake computed from 10,000 50-year traces from the water mass-balance model, with each trace startina October 1, 1998. 


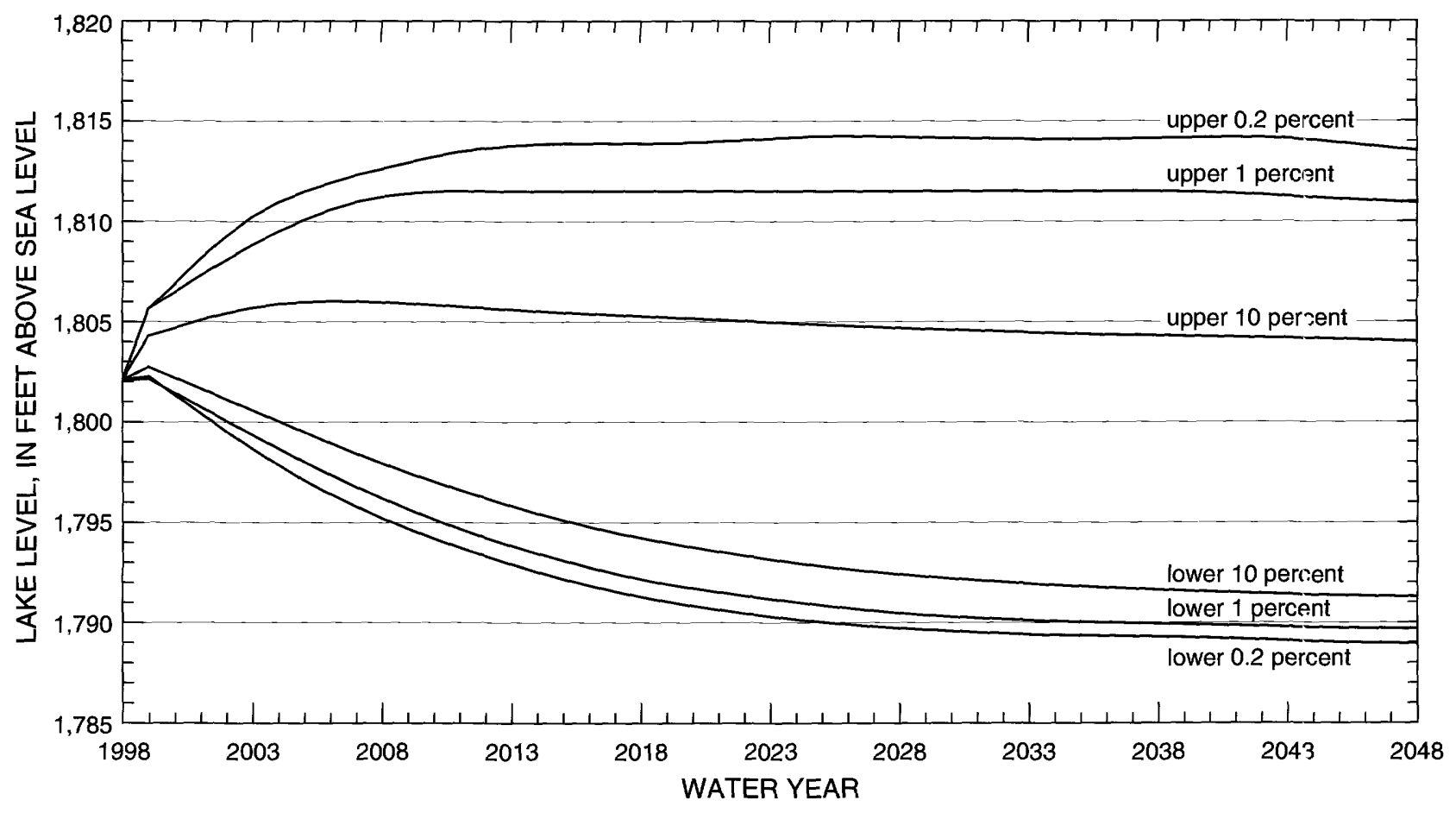

Figure 34. Upper and lower probability bounds for Minnewasta Lake computed from 10,000 50-year traces from the water mass-balance model, with each trace starting October 1, 1998.

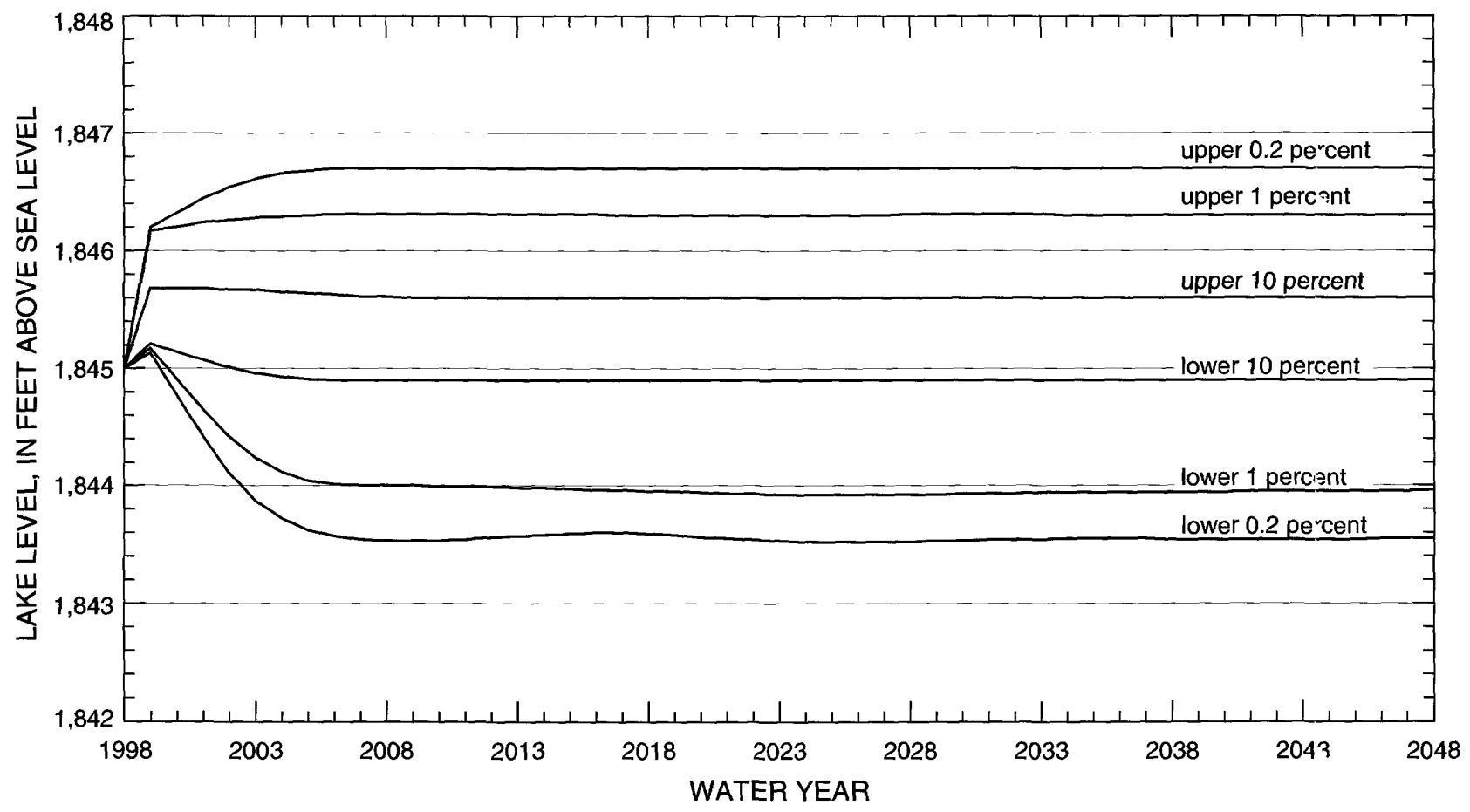

Figure 35. Upper and lower probability bounds for Pickerel Lake computed from 10,000 50-year traces from the water mass-balance model, with each trace starting October 1, 1998. 


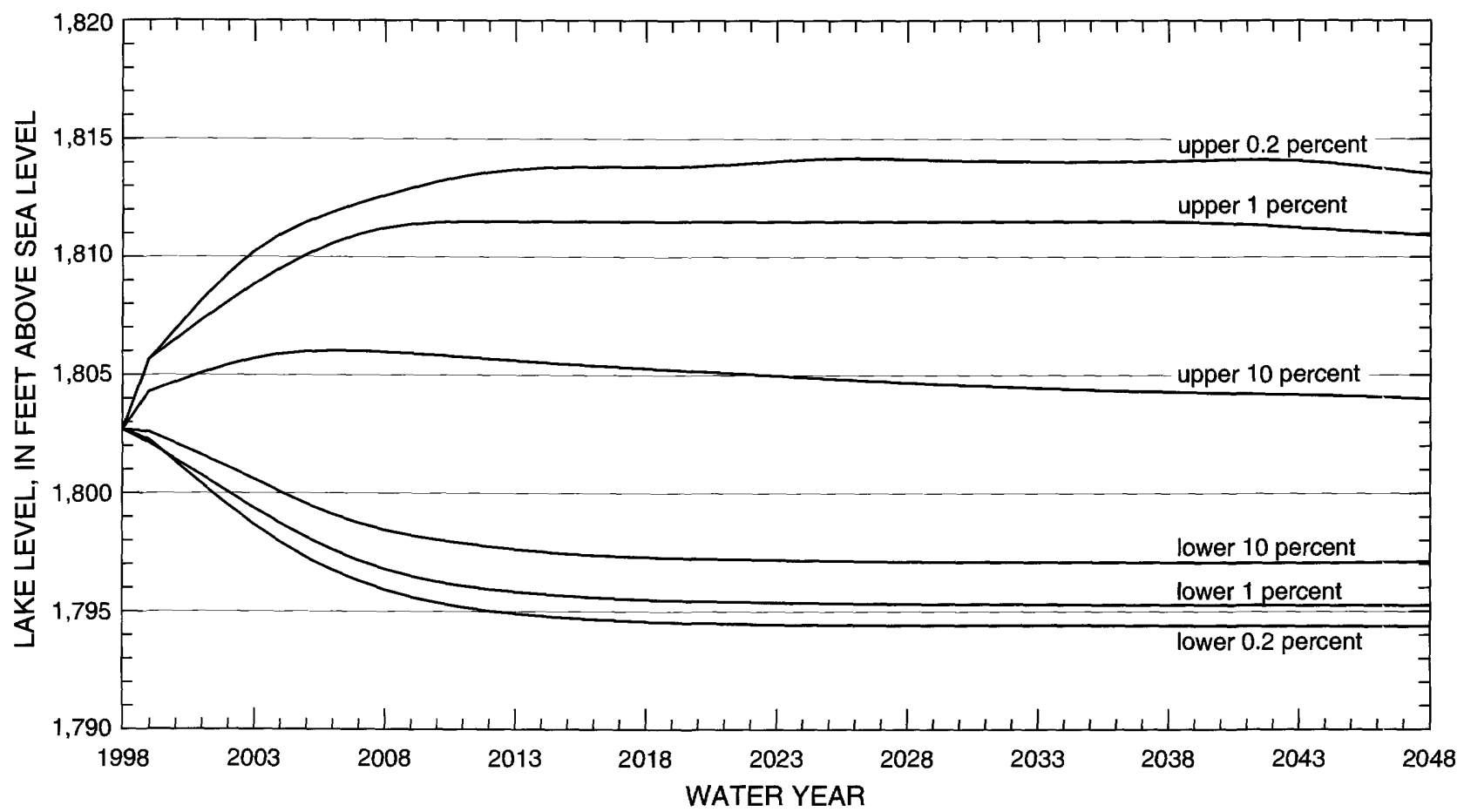

Figure 36. Upper and lower probability bounds for Rush Lake computed from 10,000 50-year traces from the water mass-balance model, with each trace starting October 1, 1998.

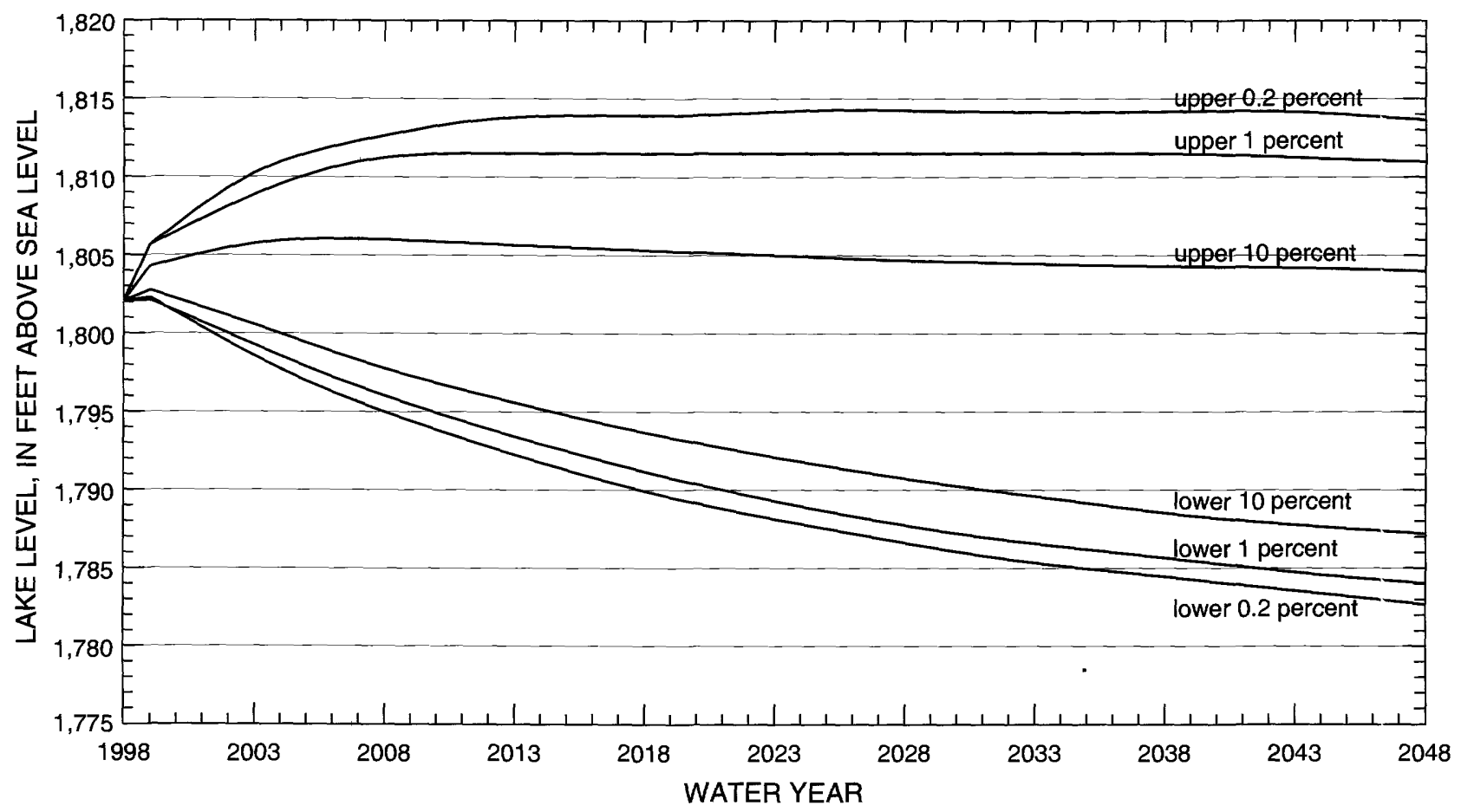

Figure 37. Upper and lower probability bounds for Spring Lake computed from 10,000 50-year traces from the wa+9r mass-balance model, with each trace starting October 1, 1998. 


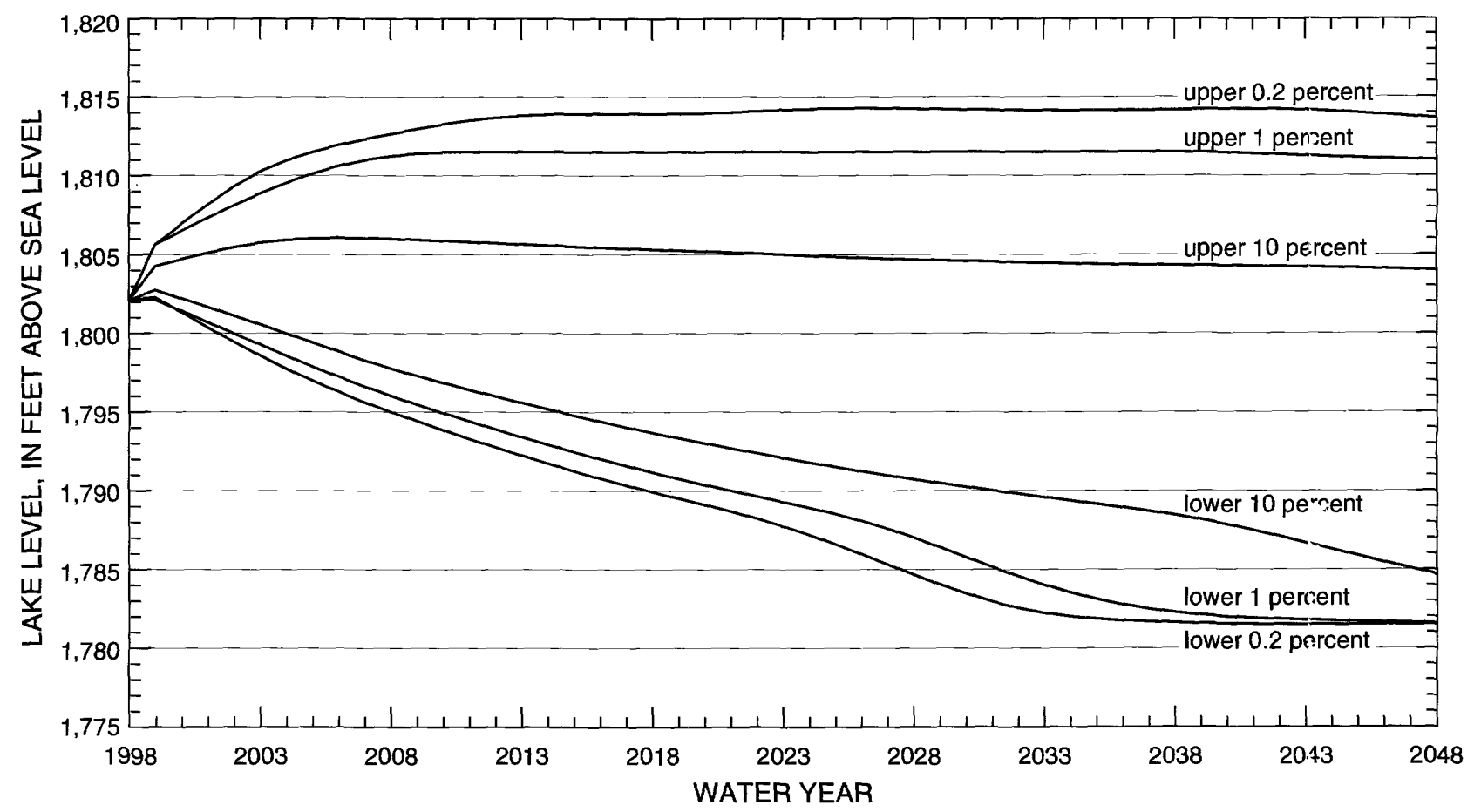

Figure 38. Upper and lower probability bounds for Swan Pond computed from 10,000 50-year traces from the water mass-balance model, with each trace starting October 1, 1998.

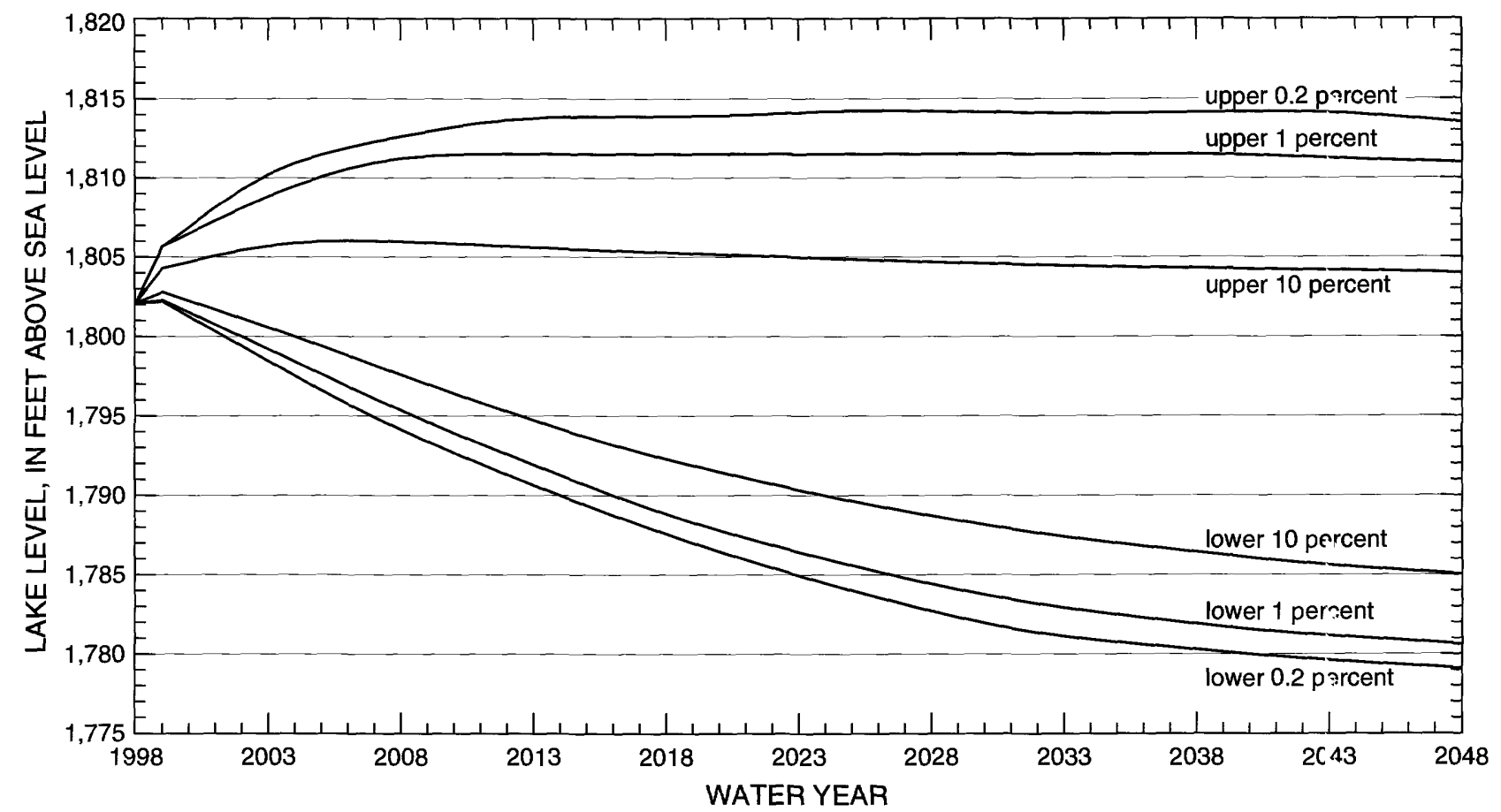

Figure 39. Upper and lower probability bounds for Waubay Lake computed from 10,000 50-year traces from the water mass-balance model, with each trace starting October 1, 1998. 
The frequency results for Bitter Lake (fig. 30) indicate the upper 10-percent probability bound increases about $8 \mathrm{ft}$ from water years 1999 to 2015 and then slowly decreases, and the upper 1-percent probability bound increases about $20 \mathrm{ft}$ from water years 1999 to 2015 and then becomes nearly constant at about an elevation of $1,810 \mathrm{ft}$. Therefore, the chance that the inundation area of Bitter Lake will continue to significantly increase during the next 15 years is high. Conversely, the lower 10-percent probability bound decreases slowly and reaches an elevation of $1,780 \mathrm{ft}$ by about water year 2040 , and the lower 1-percent probability bound decreases slowly and reaches an elevation of $1,777 \mathrm{ft}$ by about water year 2040 . Therefore, Bitter Lake is highly unlikely to return to pre1993 historic levels for at least 40 years.

The frequency results for Blue Dog Lake (fig. 31), Hillebrands Lake (fig. 33), Minnewasta Lake (fig. 34), Rush Lake (fig. 36), Spring Lake (fig. 37), Swan Pond (fig. 38), and Waubay Lake (fig. 39) indicate the upper 10-percent, 1-percent, and 0.2-percent probability bounds are about the same for all seven lakes because the lakes are joined above an elevation of 1,800.2 ft. The upper 10-percent probability bounds increase about $4 \mathrm{ft}$ from the current level and reach an elevation of $1,806 \mathrm{ft}$ in 2006 before starting to decrease, and the upper 1-percent probability bounds increase about $8 \mathrm{ft}$ from the current level and reach an elevation of $1,811.5 \mathrm{ft}$ in 2010 . These increases are smaller than the increases for Bitter Lake, partly because of water spilling from Rush Lake to Bitter Lake as the level of Rush Lake continues to increase. The upper 0.2-percent probability bounds for Bitter Lake and Rush Lake become equal after 2010 because enough water spills from Rush Lake to fill Bitter Lake to the extreme high levels of Rush Lake.

The lower probability bounds for Hillebrands, Minnewasta, Spring, and Waubay Lakes are similar, with each bound decreasing slowly during the entire 50-year simulation period and remaining above pre1993 historic lake levels for most of the simulation period. As with Bitter Lake, Hillebrands, Minnewasta, Spring, and Waubay Lakes are unlikely to decrease to "normal" levels for several decades. However, the lower probability bounds for Blue Dog Lake and Rush Lake become nearly constant in year 2010 and beyond, indicating that Blue Dog Lake and Rush Lake could return to normal (pre-1993) levels within 10 years. Blue Dog Lake and Rush Lake are much shallower than the other lakes, and both lakes spill regularly under normal climatic conditions. Therefore, levels of both lakes respond quickly to short-term climatic. reversals.

The frequency results for the upstream lakes-Enemy Swim Lake (fig. 32) and Pickerel Lake (fig. 35)-indicate a different pattern than the frequency results for the other lakes. Because both lakes spill frequently and never join with the downstream lakes, the upper probability bounds for both lake: remain nearly constant for the entire simulation period. Therefore, both lakes are unlikely to increase significantly over current levels. The lower probability bounds for Enemy Swim Lake decrease more slcrvly than those for Pickerel Lake. The bounds for En?my Swim Lake become constant in about 2030, and the bounds for Pickerel Lake become constant in about 2005. However, both lakes could return to normal levels much sooner than Bitter Lake or Waubay Lake under a reversal of the current wet conditions.

The lake extents for the Waubay Lakes Chain corresponding to the upper 0.2-, 1-, 2-, 4-, 10-, and 50 -percent probabilities (conditional analysis) are shown on plate 1 . Lake extents shown on plate 1 were developed using DEM data and do not reflect ares s that may be protected by dikes constructed near the city of Waubay in 1998. Exceedance elevations for different probabilities may be close and, therefore, their respective areas may be nearly indistinguishable at the scale shown $(1: 100,000)$.

\section{Sensitivity of Conditional Frequency Analysis to Starting Conditions}

The hydroclimatic conditions before the beginning of the simulation period have a pronounced effect on the probabilities of lake levels in the near futcre. The Waubay Lakes Chain Basin presently is higl ' $1 \mathrm{y}$ saturated, and average or even below-average precipitation in the near future can produce large runoff to the lakes. Conversely, if the basin was in a drought cycle, average or even above-average precipitation in the near future probably would produce little or no runoff:

Therefore, periodically rerunning the model to reflect new hydrologic conditions will allow public and private entities to base decisions on the most up-to-date information. 
To illustrate the effects of starting conditions, 10,000 simulated 50-year traces for Waubay lake were generated from the model using October 1, 1962, starting conditions. Computed probability bounds for the resulting simulations are shown in figure 40, and computed exceedance probabilities are given in table B11 of the Supplemental Information section. The historic lake levels of Waubay Lake for water years 1963 to 1998 also are shown in figure 40.

A comparison of the two sets of starting conditions (figs. 39 and 40) indicates the upper 1- and 0.2-percent probability bounds for Waubay Lake for the 1962 starting conditions take much longer to reach long-term equilibrium levels. However, with dry starting conditions, Waubay Lake can recover quickly and rise rapidly over the course of a few years given a sequence of wet years. Although the historic lake level did not begin to rise until the 1990's, the simulation results indicate that the lake could have risen to present levels much sooner.

The lower 1- and 0.2-percent probability bounds, using October 1, 1962, starting conditions, initially decline to less than $1,780 \mathrm{ft}$ and then slowly rise during the remainder of the simulation period (fig. 40). The same exceedance levels, using October 1, 1998, starting conditions, slowly decline through the entire simulation period (fig. 39). The decline in the lower 1and 0.2 -percent probability bounds for the October 1 , 1962, starting conditions reflects dry conditions that generally cause lake levels to decrease before eventually recovering. The historic lake level was near the lower 10-percent bound from about water years 1963 to 1992 before rising above the upper 10-percent probability bound from water years 1993 to 1998 . The decline in the lower probability bounds for the October 1, 1998, starting conditions as compared to the lower probability bounds for the October 1, 1962, starting conditions reflects the increased starting area of the lake, which causes more evaporative loss and, thus, a lake-level decline unless inflow is high enough to compensate for the increased evaporative loss.

Generally, the probability bounds produced by the model for any given exceedance probability eventually converge to the same value, no matter what starting conditions are used. This is because, as discussed earlier, the effect of the starting conditions eventually becomes negligible if the traces are observed for a long enough time.

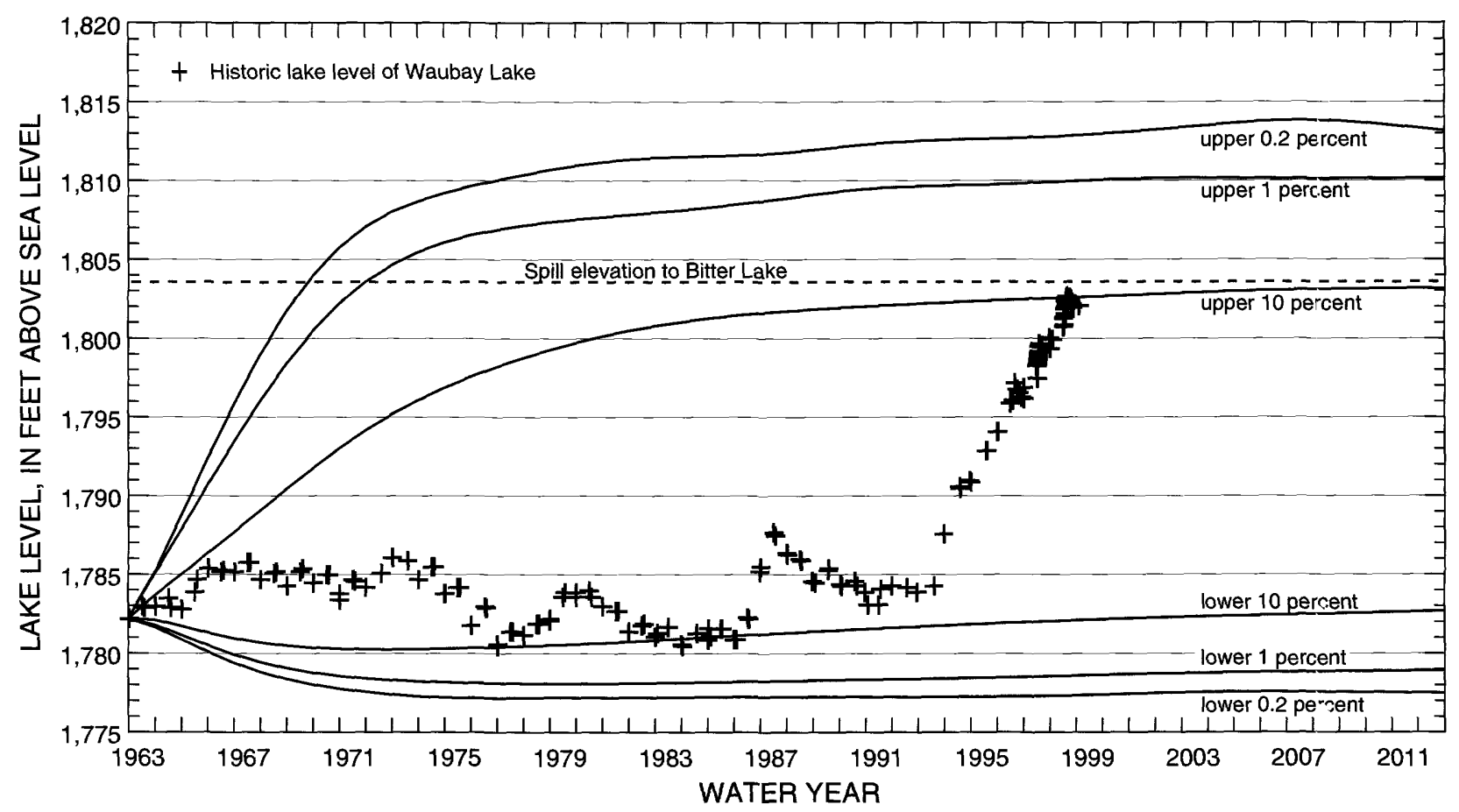

Figure 40. Upper and lower probability bounds for Waubay Lake computed from 10,000 50-year traces from the water mass-balance model, with each trace starting October 1, 1962. 


\section{Climatic Scenarios}

The main purpose of the climatic scenarios analysis was to evaluate the hydrologic response of the Waubay Lakes Chain to historic 8-year climatic segments that represent a wide range of net lake evaporation. This was done by inputting historic precipitation and evaporation data (developed for the water massbalance model) and total inflow data (generated from the stochastic time-series model) into the water massbalance model to predict resultant lake levels, areas, and volumes. Historic total inflow data were not used because total inflow is dependent on antecedent conditions of the basin. The total inflow used for the scenarios reflected the extremely wet starting conditions in the basin. The starting lake levels used in the simulations represent October 1, 1998, levels.

\section{Development}

The net lake evaporation for any period is equal to lake evaporation minus precipitation for the same period. The 8-year net lake evaporation segments given in table 16 were selected by the South Dakota State Climatologist on the basis of an analysis of precipitation and lake-evaporation data for 1961-98. This period contains a wide range of net lake evaporation. The net lake evaporation segments given in table 16 were assigned five descriptive classifications ranging from a wet period with very low net lake evaporation to a dry period with very high net lake evaporation.

The water mass-balance model was used to simulate 25 hypothetical 16-year climatic scenarios using all combinations of the five descriptive 8-year net lake evaporation segments. The model output consists of lake levels, areas, and volumes for 32 time steps representing the 16 years of simulation.
The two lakes most responsive to climate changes are Bitter and Waubay Lakes. Of the 25 hypothetical climatic scenarios, five were chosen to represent the range of resultant lake levels. The five scenarios include wet-wet, wet-dry, average-average, dry-wet, and dry-dry net lake evaporation.

Because each climatic scenario is based on an actual historic 8-year climatic segment, the fluctuation within each scenario indicates the type and magnitude of change that could be expected within that scenario rather than the actual sequence of events that could occur. Although the sequence of events within each 8-year segment is unknown, the end result of each scenario should approximate the lake conditions at that point in time. The shape of the hydrographs for each scenario for Bitter and Waubay Lakes is similar.

The model simulations for climatic scenarios wet-wet, wet-dry, average-average, dry-wet, and drydry for Bitter and Waubay Lakes show the effects of these scenarios on the levels of the two lakes (figs. 41 and 42). The wet-wet scenario, representing two consecutive 1991-98 climatic segments, results in Bitter Lake increasing $22.2 \mathrm{ft}$ above the starting lake level and Waubay Lake increasing $11.1 \mathrm{ft}$. Bitter and Waubay Lakes, after 16 years, would combine into one lake that has an elevation of $1,813.2 \mathrm{ft}$, which is $2.1 \mathrm{ft}$ above the level at which Bitter Lake would begin to flow out of the closed basin. The maximum annual water-level rise in Bitter Lake would be $3.1 \mathrm{ft}$, and the maximum annual water-level rise in Waubay Lake would be $1.8 \mathrm{ft}$, both occurring in year 2003 (corresponding to 1995 climatic conditions). When an 8 -year wet segment (1991-98) is combined with an 8-year dry segment (1969-76), Bitter Lake, after 16 years, would increase $9.8 \mathrm{ft}$ above the starting lake level, and Waubay Lake would decline $0.6 \mathrm{ft}$. The average-

Table 16. Descriptive classification of net lake evaporation and climatic scenario segments for the Waubay Lakes Chain

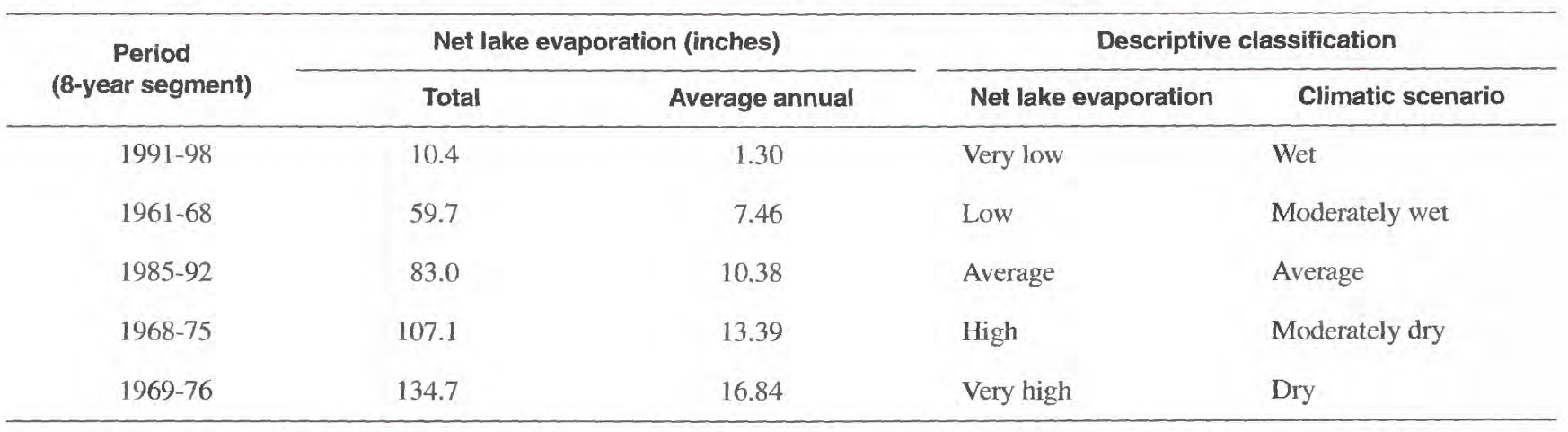




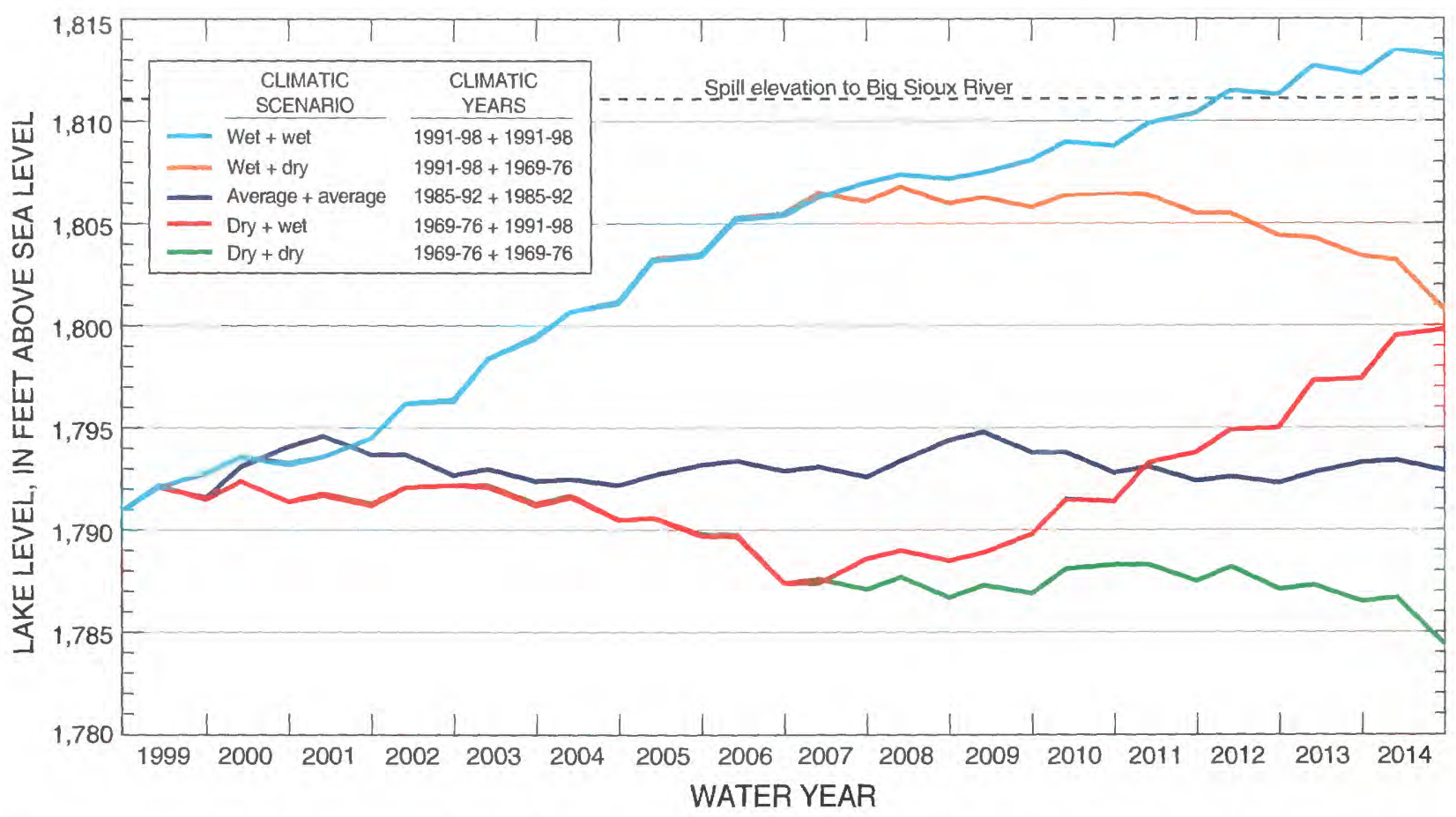

Figure 41. Simulated lake levels of Bitter Lake for selected 16-year climatic scenarios, starting with October 1, 1998, lake level.

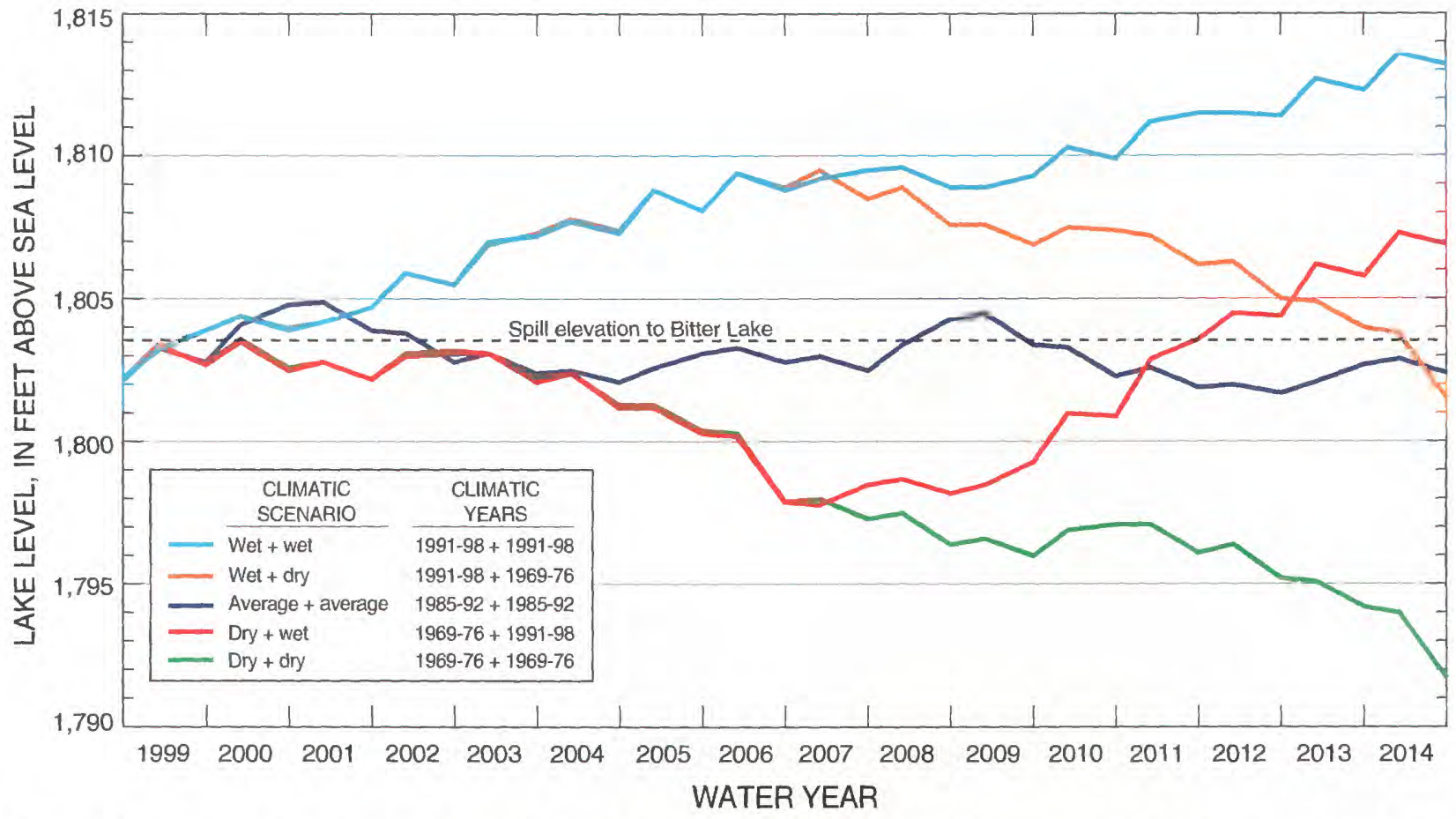

Figure 42. Simulated lake levels of Waubay Lake for selected 16-year climatic scenarios, starting with October 1, 1998, lake level. 
average climatic scenario, representing two consecutive 1985-92 climatic segments, results in little change in the levels of Bitter and Waubay Lakes. Bitter Lake would increase $1.9 \mathrm{ft}$ above the starting lake level, and Waubay Lake would increase $0.3 \mathrm{ft}$. The dry-wet climatic scenario, representing 1969-76 and 1991-98 climatic segments, results in Bitter Lake increasing $8.8 \mathrm{ft}$ above the starting lake level and Waubay Lake increasing $4.8 \mathrm{ft}$. When an 8 -year dry segment is combined with another 8-year dry segment, Bitter Lake, after 16 years, would decline $6.6 \mathrm{ft}$ from the starting lake level, and Waubay Lake would decline $10.4 \mathrm{ft}$. The maximum annual water-level decline in Bitter Lake would be $2.4 \mathrm{ft}$ in year 2006, and the maximum annual water-level decline in Waubay Lake would be $2.5 \mathrm{ft}$ in years 2006 and 2014 (all years corresponding to 1976 climatic conditions).

The lake extents for the Waubay Lakes Chain at the end of the dry-dry and wet-wet climatic scenarios, as well as the October 1, 1998, and upper 1-percent probability lake levels (conditional analysis), are shown on plate 2. As on plate 1 , the lake extents do not reflect areas that may be protected by dikes constructed near the city of Waubay in 1998 . The wet-wet scenario and the upper 1-percent probability lake levels are very similar and have similar lake extents.

\section{Probabilities}

Results from the lake-level frequency analysis were used to determine the probability of the five selected scenarios (wet-wet, wet-dry, average-average, dry-wet, and dry-dry). The conditional frequency analysis was performed for Waubay Lake using 10,000 simulated 16-year lake-level traces generated using the water mass-balance and stochastic time-series models and October 1, 1998, starting conditions. The 0.2-, 1-, and 10-percent upper and lower probability bounds and the five 16-year traces generated for the selected scenarios for Waubay Lake are shown in figure 43. The five selected scenarios seem to represent essentially the full range of future lake levels. The lake levels after 16 years range from about the lower 1-percent probability bound for the dry-dry scenario, which corresponds to very dry conditions, to about the upper 0.2-percent probability bound for the wet-wet scenario, which corresponds to very wet conditions. The average-average scenario is near the 50 -percent probability bound after 16 years.

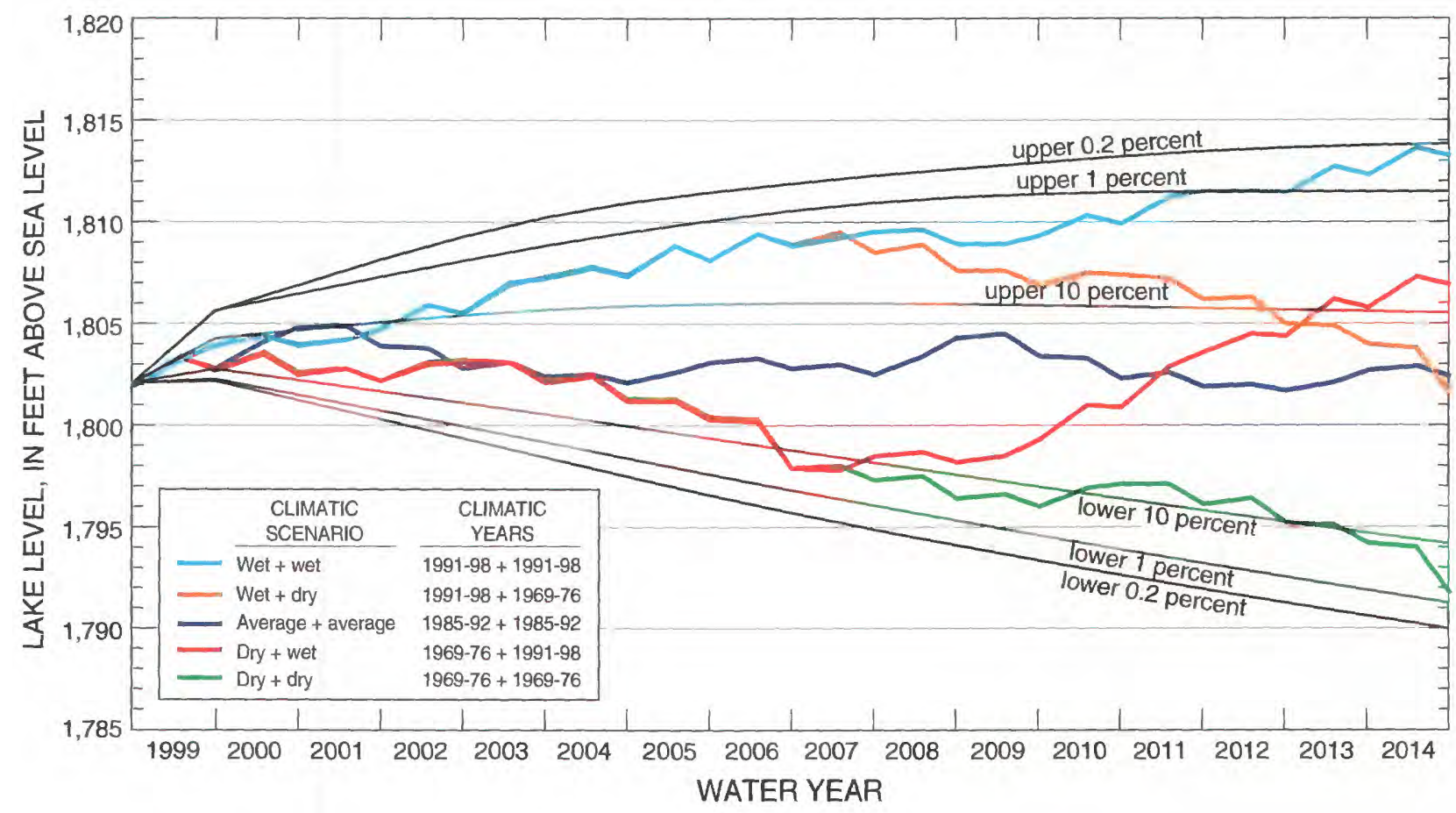

Figure 43. Probability bounds and selected 16-year scenario results for Waubay Lake. 


\section{SUMMARY}

In response to significant increases in lake levels in northeastern South Dakota during the 1990's, a water mass-balance model and a stochastic time-series model were used for a lake-level frequency analysis for the Waubay Lakes Chain. The 10 major lakes in this chain include Bitter Lake, Blue Dog Lake, Enemy Swim Lake, Hillebrands Lake, Minnewasta Lake, Pickerel Lake, Rush Lake, Spring Lake, Swan Pond, and Waubay Lake. Lake outlet elevations existing as of April 1999 were used in the frequency analysis.

Lake-level rises for Bitter Lake, Hillebrands Lake, Spring Lake, Swan Pond, and Waubay Lake have ranged from 15.1 to 18.6 feet from May 1993 to April 1999. The area of the entire Waubay Lakes Chain is about 1.7 times greater than in May 1993, and the volume is about 3.2 times greater. The rising lake levels have resulted in substantial damage to public and private property in the basin. Numerous public roads, highways, parks, and recreational facilities, thousands of acres of farmland, and numerous farmsteads, homes, and lake-front properties have been inundated or damaged.

The water mass-balance model was developed to simulate semiannual lake volumes of the 10 major lakes of the Waubay Lakes Chain using precipitation, evaporation, total inflow to the system, and starting lake levels as input. The model simulated the volumes by accounting for all water entering and leaving each lake. The lake volume at the end of a time step was computed as (1) the lake volume at the beginning of the time step, (2) plus precipitation falling directly on the lake, (3) minus evaporation directly from the lake, (4) plus inflow from surface runoff, (5) plus or minus flow between lakes.

The first step in development of the model was to compile historic data to construct and verify the model. The second step was to analyze the historic data to gain an understanding of the Waubay Lakes Chain. Historic lake-level data were compiled from all available sources, but most of the data were obtained from the South Dakota Department of Environment and Natural Resources and the Waubay National Wildlife Refuge. Water years 1963-98 were selected for model development because of the availability of lake-level data. Missing data were generated as needed using regression, and a semiannual lake-level record was constructed using two semiannual periods, winter and summer. The winter period is from October 1 (the beginning of the water year) through April 30, and the summer period is from May 1 through September 30 (the end of the water year). Semiannual precipitation data were compiled from records collected at the Waubay National Wildlife Refuge, and evaporation data were estimated using a modification of the Morton method. The evaporation data used for this method were obtained from the Agricultural and Biosystems Engineering Department at South Dakota State University.

Because the water mass-balance model operates on lake volumes rather than lake levels, lake area and capacity tables were needed to convert lake levels to lake volumes and determine associated storage changes. Digital contour maps were developed from bathymetric maps and 10-meter digital elevation model data. Bathymetric maps of Blue Dog, Enemy Swim, Minnewasta, Pickerel, and Waubay Lakes were available from the South Dakota Department of Game, Fish and Parks. The U.S. Geological Survey collected bathymetric data for the remaining five lakes.

Semiannual total inflow to the Waubay Lakes Chain was estimated using the assumption that the basin containing the lakes chain is a closed system that has no surface and subsurface inflow or outflow across its boundary. The volume of water in the system at a given time step was set equal to the volume of water in the system at the previous time step plus the water from precipitation falling on the lakes minus the water evaporating from the lakes plus total inflow from surface runoff.

Total inflow was apportioned among the 10 major lakes of the Waubay Lakes Chain using regression. Next, flow between lakes was incorporated into the model using an iterative process, if needed, to balance the level of each lake, taking into account flow from connecting lakes. The iterative process was continued until all lakes were balanced for a particular time step. Outlet rating equations to compute flow between some lakes were developed and incorporated into the model.

Results of the water mass-balance model for each individual lake and for the Waubay Lakes Chain were verified using historic 1963-98 data. The match between simulated and historic lake levels, areas, and volumes was good.

The stochastic time-series model was developed to generate hypothetical future sequences of semiannual precipitation, evaporation, and total inflow. The model was used to generate two different simulations of 10,000 years of data. Simulation 1 was based on the 
assumption that 1963-98 is representative of long-term climatic conditions. Simulation 2 was based on the assumption that the long-term climatic conditions are slightly drier than the historic 1963-98 climatic conditions. For simulation 2, the precipitation and evaporation data generated for simulation 1 were altered slightly by decreasing the precipitation data by 5 percent and increasing the evaporation data by 3 percent. These changes in precipitation and evaporation reduced total inflow by about 15 percent. The historic precipitation, evaporation, and total inflow data fit well with the generated data for both climatic simulations, and the historic data are statistically indistinguishable from the generated data for both simulations.

Frequencies of extreme high or low lake levels generated from the water mass-balance and stochastic time-series models for the two simulations were verified from information on historic lake levels and climate, tree-ring chronologies, and soil surveys. The comparisons between the simulations indicate simulation 2 is much more representative of historic lake-level fluctuations than simulation 1. Thus, climate conditions during water years 1963-98 probably were wetter than normal when considered in the context of a much longer historic record. Because simulation 2 adequately reproduces long-term historic lake-level fluctuations and simulation 1 is biased toward high lake levels, all frequency results were based on the assumptions used to generate simulation 2.

Because lake levels of closed-basin lakes are characterized by high serial persistence, two frequency analysis methods (unconditional and conditional) were used. Unconditional frequency analysis estimates the frequencies of high or low lake levels for a long time period during which the lake levels cycle many times between wet and dry periods. The starting conditions at the beginning of the simulation period have no effect on the analysis because of the long simulation period. Conditional frequency analysis, or position analysis, estimates the frequencies of hypothetical future lake levels for a relatively short time period, such as 50 years. Because of the short time period, the starting conditions at the beginning of the simulation period have an effect on the frequencies of the lake levels. For example, the probability of Bitter Lake spilling to the Big Sioux River sometime in the next 50 years is relatively high because of the much higher-than-normal current lake level. Thus, although, the average time interval between natural spills to the Big Sioux River is more than 1,000 years on the basis of the uncondit 'nal frequency analysis, the probability of the lake spilling in the next 50 years is greater than 1 in 1,000. Because studies that relate to flood-risk-assessment or floodmitigation alternatives usually are pertinent only for relatively short time periods into the future, conditional frequency analysis usually is more appropriate th`n unconditional frequency analysis.

Unconditional frequency analysis was performed for Bitter, Enemy Swim, Pickerel, and Waubay Lakes using the 10,000 years of generated lake levels for simulation 2. The 1-percent exceedance level for Waubay Lake is at an elevation of $1,811.5 \mathrm{ft}$, which is approximately equal to the closed-basin spill elevation to the Big Sioux River. However, only 13 separate spill events with an average duration of 8 years occurred during the 10,000-year simulation period, giving an average return period of 769 years. Therefore, because of the high serial persistence in the lake levels, th : return period corresponding to the 1-percent exceedance level for Waubay Lake is much longer than 100 years. The values for the remaining six lakes are identical to those for Waubay Lake because these six lakes are joined with Waubay Lake at these lake levels.

The lake levels for the 1-percent exceedance probabilities (unconditional analysis) are about $19 \mathrm{ft}$ higher for Bitter Lake, $1.2 \mathrm{ft}$ higher for Enemy Swim Lake, $0.7 \mathrm{ft}$ higher for Pickerel Lake, and $8.6 \mathrm{ft}$ higher for Waubay Lake than the levels of those lakes on April 4, 1999. However, the average return periods are 909 years for Bitter Lake, 185 years for Enemy Swim Lake, 155 years for Pickerel Lake, and 769 years for Waubay Lake. The average return periods for Eremy Swim and Pickerel Lakes for the 0.2-percent exceedance probabilities (unconditional analysis) were 500 years, indicating the extreme high lake levels of the smaller upstream lakes probably are caused by 1 year climatic extremes. However, the average return periods for Bitter and Waubay Lakes for the 0.2-percent exceedance probabilities (unconditional analysis) are 2,000 years, indicating the extreme high lake lovels of the larger downstream lakes probably are caused by extreme climatic conditions lasting several years.

The frequencies for extreme low lake levels are difficult to accurately determine because small changes in lake volumes result in large changes in lake levels. The lake levels of Enemy Swim, Pickerel, and Waubay Lakes in the 1930's and 1940's were very low compared to the long-term lake levels. 
The conditional frequency analysis was performed for the 10 major lakes of the Waubay Lakes Chain using 10,000 simulated 50-year lake-level traces, each starting on October 1,1998 . The generated data can be used to estimate the probability of virtually any event that involves future lake levels.

The upper 1-percent probability bound (conditional analysis) for Waubay Lake rises quickly to a constant level at an elevation of $1,811.5 \mathrm{ft}$, which corresponds to the unconditional 1-percent exceedance level. Therefore, the chance that Waubay Lake will continue to rise to the spill elevation with the Big Sioux River within the next 20 years is relatively high (greater than 1 percent). The lower 1-percent probability bound (conditional analysis) for Waubay Lake falls slowly during the next 50 years and reaches the unconditional lower 1-percent exceedance level well beyond 2048. Thus, Waubay Lake is unlikely to return to levels comparable to historic 1960-92 levels for at least 40 years. Also, Waubay Lake is unlikely to return to levels comparable to those during the extreme drought of the 1930's for much longer than 50 years.

The upper 10-percent probability bound (conditional analysis) for Bitter Lake increases about $8 \mathrm{ft}$ from water years 1999 to 2015 and then slowly decreases, and the upper 1-percent probability bound (conditional analysis) increases about $20 \mathrm{ft}$ from water years 1999 to 2015 and then becomes nearly constant at an elevation of about $1,810 \mathrm{ft}$. Therefore, the chance that the level of Bitter Lake will continue to significantly increase during the next 15 years is high. Conversely, the lower 10-percent probability bound (conditional analysis) for Bitter Lake decreases slowly and reaches an elevation of $1,780 \mathrm{ft}$ by about water year 2040, and the lower 1-percent probability bound (conditional analysis) decreases slowly and reaches an elevation of $1,777 \mathrm{ft}$ by about water year 2040 . Therefore, Bitter Lake is highly unlikely to return to historic pre-1993 levels for at least 40 years.

The conditional frequency results for Blue Dog Lake, Hillebrands Lake, Minnewasta Lake, Rush Lake, Spring Lake, Swan Pond, and Waubay Lake indicate the upper 10-, 1-, and 0.2-percent probability bounds are about the same for all seven lakes because the lakes are joined at these lake levels. The upper 10-percent probability bounds increase about $4 \mathrm{ft}$ from the current level and reach an elevation of $1,806 \mathrm{ft}$ in 2006 before starting to decrease, and the upper 1-percent probability bounds increase about $8 \mathrm{ft}$ from the current level and reach an elevation of $1,811.5 \mathrm{ft}$ in 2010 . The upper 0.2-percent probability bounds for Bitter Lake and Rush Lake become equal after 2010 berause enough water spills from Rush Lake to fill Bitter Lake to the extreme high levels of Rush Lake.

The lower probability bounds (conditional analysis) for Hillebrands, Minnewasta, Spring, and Waubay Lakes are similar, with each bo' Ind decreasing slowly during the entire 50-year simulation period and remaining above pre-1993 historic lake levels for most of the simulation period. Hillebrands, Minnewasta, Spring, and Waubay Lakes are similar to Bitter Lake in that they are unlikely to decrease to "normal" levels for several decades. However, the lower p"obability bounds (conditional analysis) for Blue Dog Lake and Rush Lake become nearly constant in year 2010 and beyond, indicating that Blue Dog Lake and Rush Lake could return to normal (pre-1993) levels within 10 years.

The frequency results for Enemy Swim and Pickerel Lakes indicate a different pattern than the frequency results for the other lakes. Because both lakes spill frequently and never join with the downstream lakes, the upper probability bounds (conditional analysis) for both lakes remain nearly constant for the entire simulation period. Therefore, levels of both lakes are unlikely to increase significantly over current levels. Both lakes could return to normal levels much sooner than Bitter Lake or Waubay Lake under a reversal of the current wet conditions.

The hydroclimatic conditions before the beginning of the simulation period have a prc nounced effect on the probabilities of lake levels in the near future. The Waubay Lakes Chain Basin presently is highly saturated, and average or even below-average precipitation in the near future can produce large runoff to the lakes. Conversely, if the basin was in a drought cycle, average or even above-average precipitation in the near future probably would produce little or no runoff.

To illustrate the effects of starting conditions, 10,000 simulated 50-year traces (conditional analysis) for Waubay Lake were generated from the model using October 1, 1962, starting conditions. A comparison of the two sets of starting conditions indicates the upper 1and 0.2-percent probability bounds (conditional analysis) for Waubay Lake for the 1962 starting conditions take much longer to reach long-term ecrilibrium levels. However, with dry starting conditions, Waubay Lake can recover quickly and rise rapidly over the course of a few years given a sequence of wet years. 
The lower 1- and 0.2-percent probability bounds (conditional analysis), using October 1, 1962, starting conditions, initially decline to less than $1,780 \mathrm{ft}$ and then slowly rise during the remainder of the simulation period. The same exceedance levels, using October 1, 1998, starting conditions, slowly decline throughout the entire simulation period. The decline in the lower 1 - and 0.2-percent probability bounds for the

October 1, 1962, starting conditions reflects dry conditions that generally cause lake levels to decrease before eventually recovering. The historic lake level was near the lower 10-percent bound from about water years 1963 to 1992 before rising above the upper 10-percent probability bound from water years 1993 to 1998 .

Generally, the probability bounds (conditional analysis) produced by the models for any given exceedance probability eventually converge to the same value, no matter what starting conditions are used. This is because, as discussed earlier, the effect of the starting conditions eventually becomes negligible if the traces are observed for a long enough time.

A climatic scenarios analysis was done to evaluate the hydrologic response of the Waubay Lakes Chain to historic 8-year climatic segments that represent a wide range of net lake evaporation. This was done by inputting historic precipitation and evaporation data (developed for the water mass-balance model) and total inflow data (generated from the stochastic time-series model) into the water mass-balance model to predict resultant lake levels, areas, and volumes. Historic total inflow data were not used because total inflow is dependent on antecedent conditions of the basin. The starting lake levels used in the simulations represent October 1, 1998, levels. The water massbalance model was used to simulate 25 hypothetical 16-year climatic scenarios using all combinations of the five descriptive 8-year net lake evaporation segments. Of these 25 hypothetical climatic scenarios, five were chosen to represent the range of resultant lake levels. The five scenarios include wet-wet, wet-dry, average-average, dry-wet, and dry-dry net lake evaporation.

The wet-wet scenario, representing two consecutive 1991-98 climatic segments, results in Bitter Lake increasing $22.2 \mathrm{ft}$ above the starting lake level and Waubay Lake increasing $11.1 \mathrm{ft}$. Bitter and Waubay Lakes, after 16 years, would combine into one lake that has an elevation of $1,813.2 \mathrm{ft}$, which is $2.1 \mathrm{ft}$ above the level at which Bitter Lake would begin to flow out of the closed basin. When an 8-year wet segment
(1991-98) is combined with an 8-year dry segmert (1969-76), Bitter Lake, after 16 years, would increase $9.8 \mathrm{ft}$ above the starting lake level, and Waubay Lake would decline $0.6 \mathrm{ft}$. The average-average climat: scenario, representing two consecutive 1985-92 climatic segments, results in little change in the levels of Bitter and Waubay Lakes. The dry-wet climatic scenario, representing 1969-76 and 1991-98 climatic segments, results in Bitter Lake, after 16 years, increasing $8.8 \mathrm{ft}$ above the starting lake level and Waubay Lake increasing $4.8 \mathrm{ft}$. When an 8-year dry segment is combined with another 8-year dry segment, Bitter Lake, after 16 years, would decline $6.6 \mathrm{ft}$ from the starting lake level, and Waubay Lake would decline $10.4 \mathrm{ft}$.

The conditional frequency analysis performed for Waubay Lake with October 1, 1998, starting conditions were compared to the scenario results. The five selected scenarios seemed to represent essentially the full range of hypothetical future lake levels. The lake levels after 16 years range from about the lower 1-percent probability bound for the dry-dry scenario to about the upper 0.2-percent probability bound for the wet-wet scenario. The average-average scenario is near the 50 -percent probability bound after 16 years.

\section{SELECTED REFERENCES}

Agricultural and Biosystems Engineering Department, 1999, Total pan evaporation for Brookings 2NE, lake evaporation for Day County: South Dakota State University, accessed January 12, 1999, at URL http:// www.abs.sdstate.edu/ae/weather/uome/ day/ day_evap.csv.

Amundson, F.D., Bradford, Wendell, and Koch, N.C., 1985, Drainage areas in the Big Sioux River Basin in eartern South Dakota: U.S. Geological Survey Open-File Report 85-348, 1 sheet.

Benson, R.D., Freese, M.E., Amundson, F.D., and Wirf, V.J., 1987, Drainage areas in the James River Basin in eastern South Dakota: U.S. Geological Survey O renFile Report 87-572, 1 sheet.

Bowles, D.S., and James, L.D., 1986, Issues associated with stochastic modeling of Great Salt Lake levels for planning purposes, in Kay, P.A., and Diaz, H.F., eds., Problems of and prospects for predicting Great Salt Lake levels: Center for Public Affairs Administration, University of Utah, May 1985, p. 218-235.

Bryce, S.A., Omernik, J.M., Pater, D.E., Ulmer, Michsel, Schaar, Jerome, Freeouf, Jerry, Johnson, Rex, Ku:k, Pat, and Azevedo, S.H., 1998, Ecoregions of North Dakota and South Dakota: Dynamac Corporation, 1 sheet. 
Carter, J.M., and Thompson, R.F., 1999, Selected hydrologic data through 1996 for the Lake Traverse Reservation/ Roberts County water-resources investigation in South Dakota: U.S. Geological Survey Open-File Report 98-647, 243 p.

Draper, N.R, and Smith, H., 1981, Applied regression analysis ( $2 \mathrm{~d}$ ed.): New York, Wiley, 709 p.

Flint, R.F., 1955, Pleistocene geology of eastern South Dakota: U.S. Geological Survey Professional Paper 262, $173 \mathrm{p}$.

Gary, Margaret, McAfee, Robert, Jr., and Wolf, C.L., eds., 1972, Glossary of geology: American Geological Institute, $805 \mathrm{p}$.

Gries, J.P., 1996, Roadside geology of South Dakota: Missoula, Mont., Mountain Press, 358 p.

Hem, J.D., 1985, Study and interpretation of the chemical characteristics of natural water ( $3 d$ ed.): U.S. Geological Survey Water-Supply Paper 2254, 263 p.

James, L.D., Bowles, D.S., and Burges, S.J., 1977, Stochastic modeling for predicting frequency distributions of states in terminal lakes at future planning horizons, in Greer, D.C., ed., International Conference on Desertic Terminal Lakes, Ogden, Utah, May 1977, Proceedings: Logan, Utah State University, Utah Water Resource Laboratory, p. 81-89.

Leap, D.I., 1988, Geology and hydrology of Day County, South Dakota: South Dakota Geological Survey Bulletin 24, $117 \mathrm{p}$.

Morton, F.I., 1979, Climatological estimates of lake evaporation: Water Resources Research, v. 13, no. 1, p. 64-76.

National Climatic Data Center, 1998, Monthly precipitation data for U.S. Cooperative and National Weather Service sites-South Dakota: accessed November 17, 1998, at URL http://www.ncdc.noaa.gov/pub/data/coop-precip/ south-dakota.txt.
Petri, L.R., and Larson, L.R., 1968, Quality of water in lakes in eastern South Dakota: South Dakota Water Resources Commission Report of Investigations No. 1, $55 \mathrm{p}$.

Rothrock, E.P., 1935, Geology and water resources of Day County, South Dakota: South Dakota Geological Survey Report of Investigation No. 25, 42 p.

State Lakes Preservation Committee, 1977, A plan for the classification, preservation, restoration of lakes in northeastern South Dakota: South Dakota and Old West Regional Commission, $268 \mathrm{p}$.

Steuven, Eugene, and Stewart, W.C., 1996, 1995 South Dakota Lakes Assessment Final Report: South Dakota Department of Environment and Natural Resources, $760 \mathrm{p}$.

Tasker, G.D., 1997, Bootstrap position analysis for forecasting low flow frequency: Journal of Water Resources Planning and Management, v. 123, no. 6, p. 359-367.

U.S. Department of Commerce, 1950-98, Monthly climatological data, South Dakota: Asheville, North Carolina (published annually). 1965, Climatic summary of the United States, Supplement for 1951-1960, South Dakota: Asheville, North Carolina, $75 \mathrm{p}$.

U.S. Geological Survey, 1998, Water resources data for South Dakota, water year 1997: U.S. Geological Survey Water Data Report SD-97-1, 361 p.

U.S. National Oceanic and Atmospheric Administration, 1998-99, Climatological data for South Dakota: Asheville, N.C. (published monthly).

Wiche, G.J., and Vecchia, A.V., 1996, Lake-level frequency analysis for Devils Lake, North Dakota: U.S. Geological Survey Water-Supply Paper 2469, $57 \mathrm{p}$.

Yevjevich, Vujica, 1982, Determination metl ' d for computing the probabilities of exceedance of future levels of Devils Lake, North Dakota: Contract I ACW 37-82M-1562, June 9, 1982. 


\section{SUPPLEMENTAL INFORMATION}


Section A - Photographs of Selected Features

of the Waubay Lakes Chain 


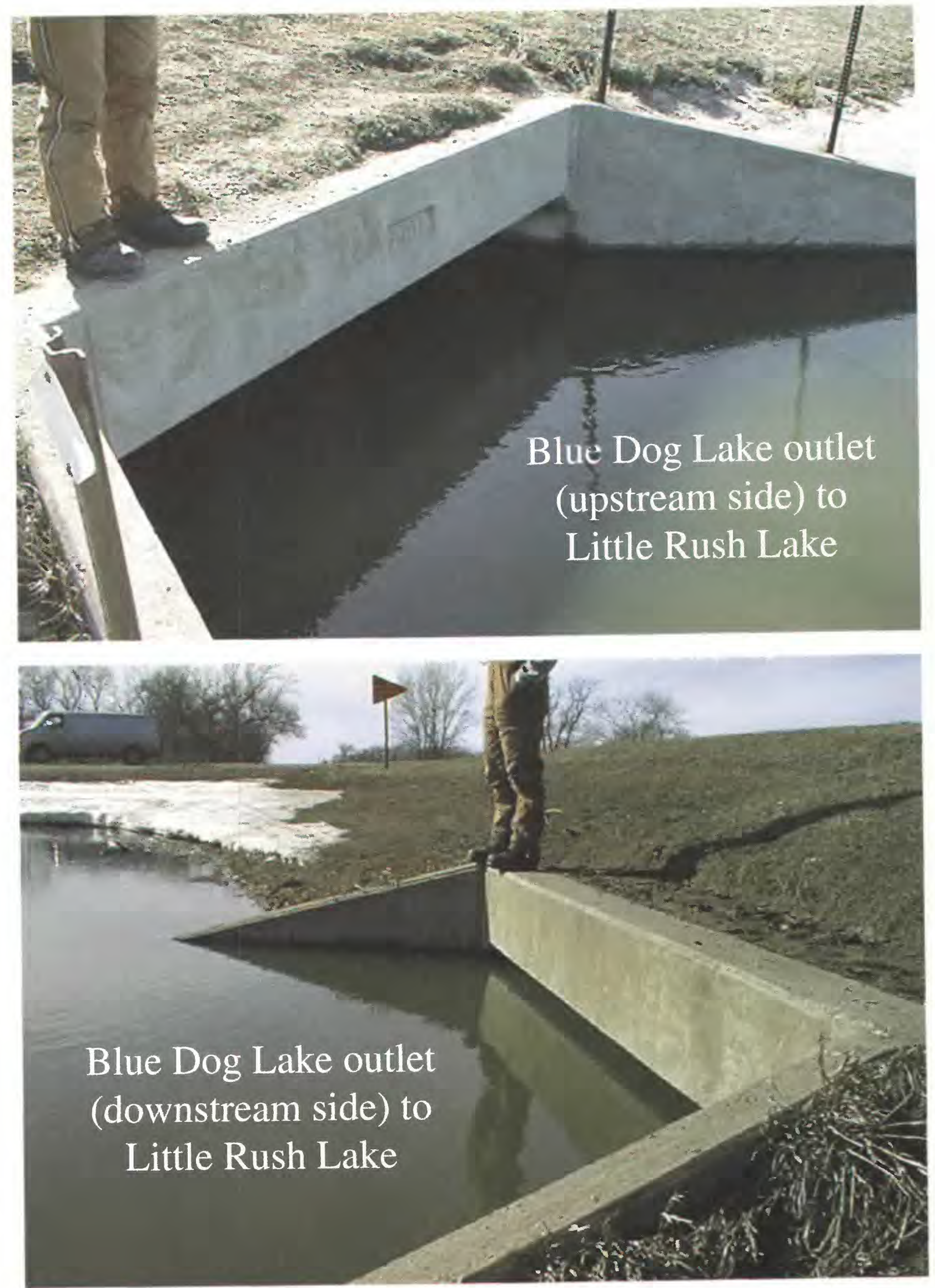

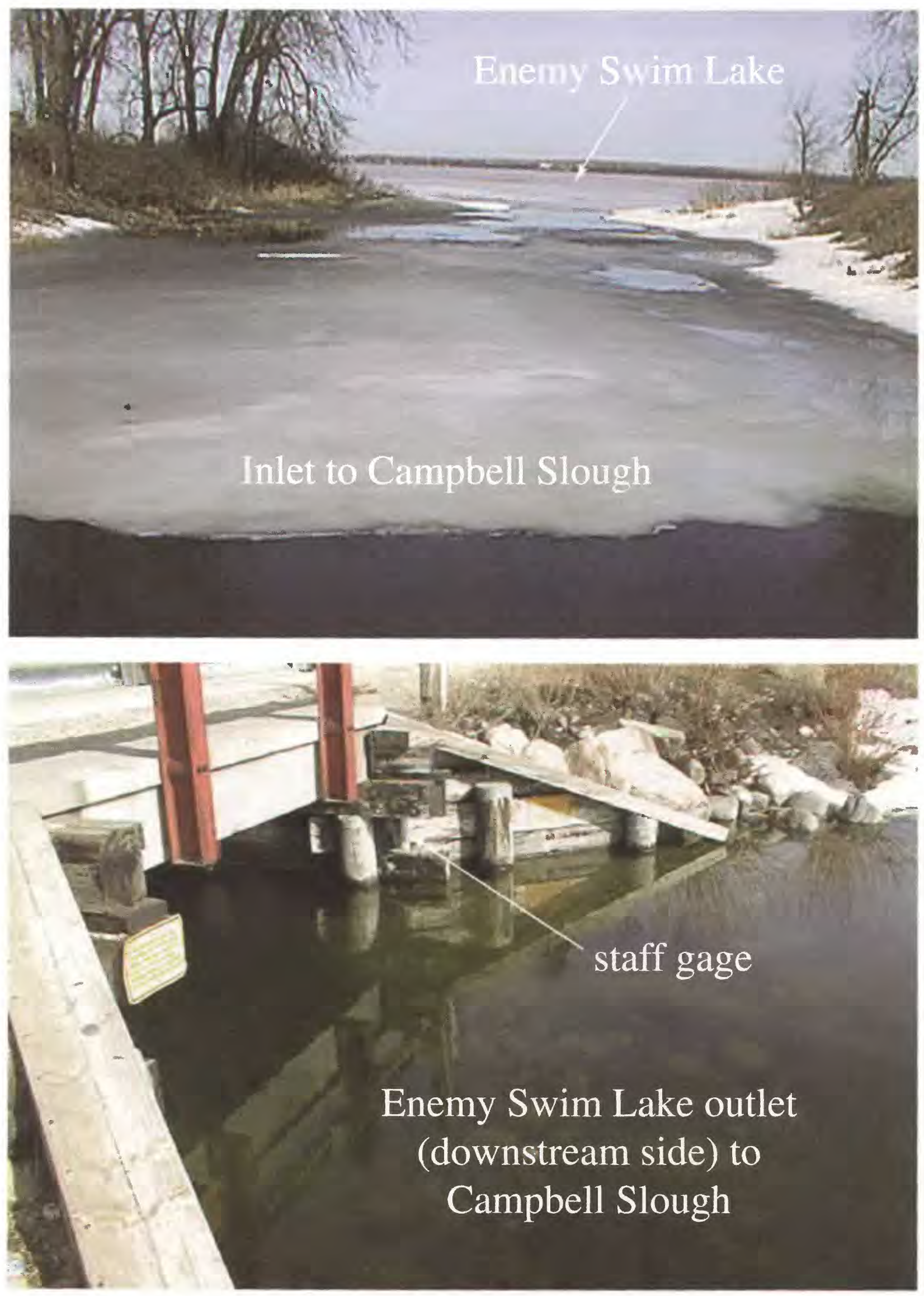

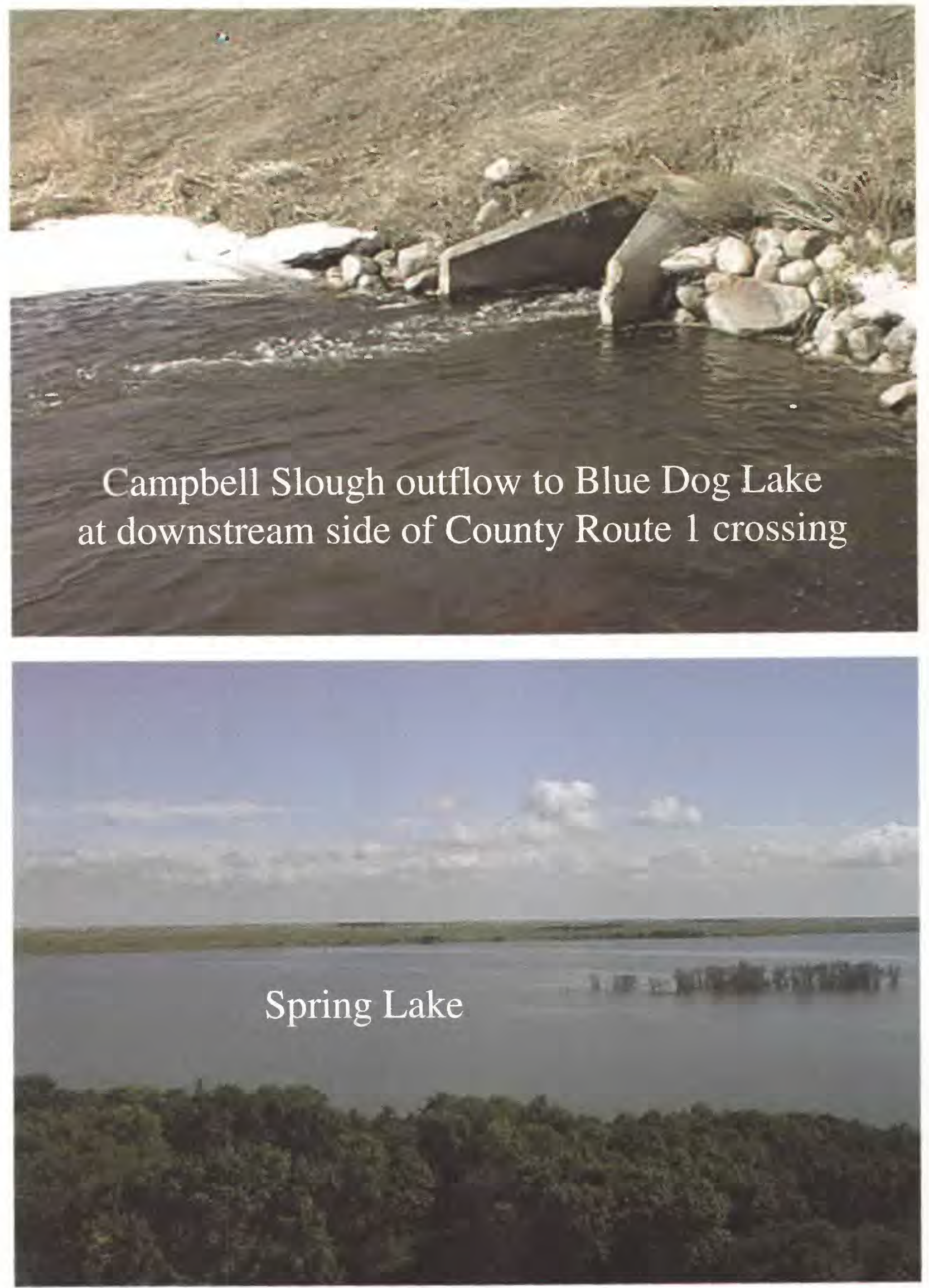

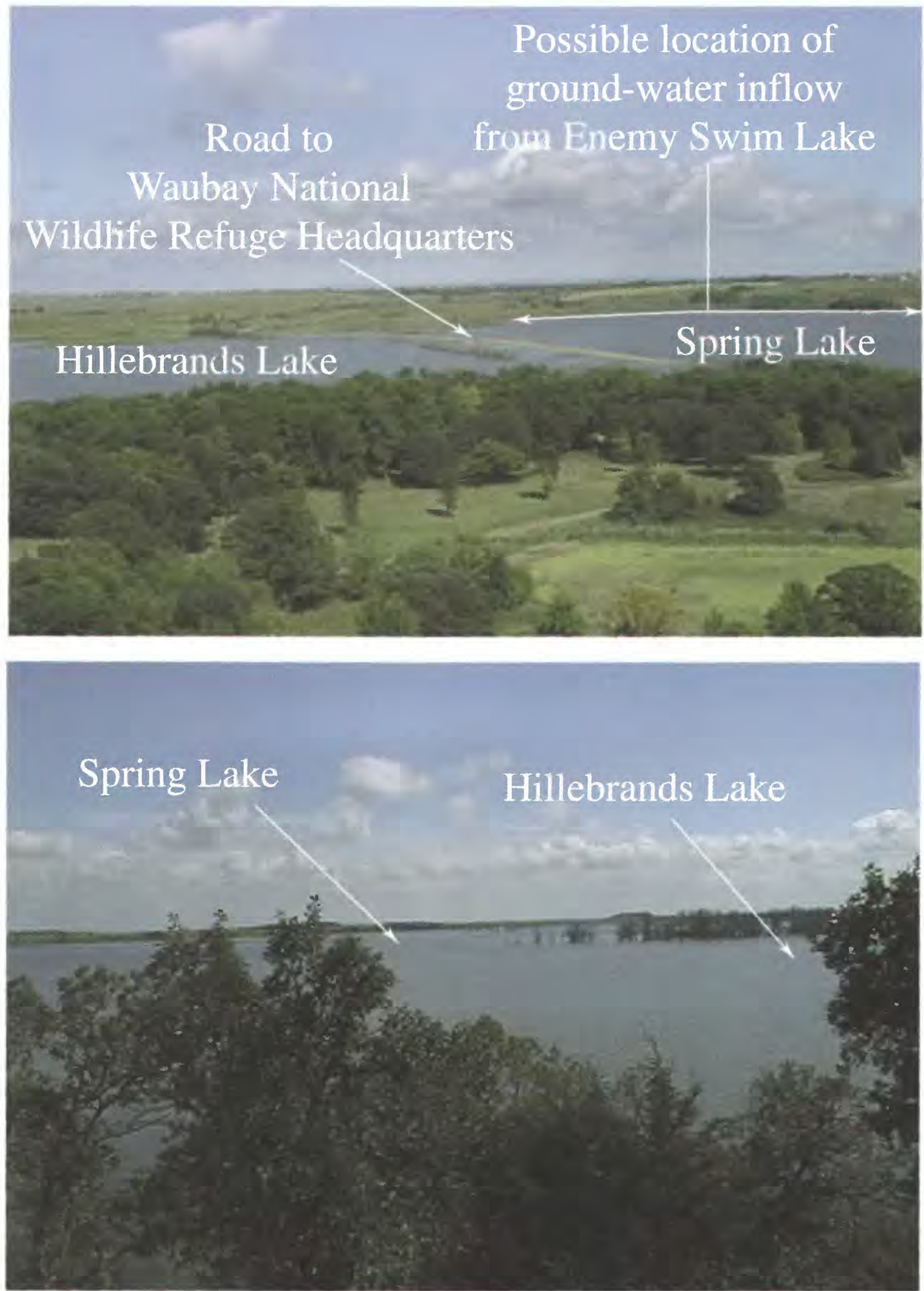


\section{Wambay Lake}

- Hillebrands Lake
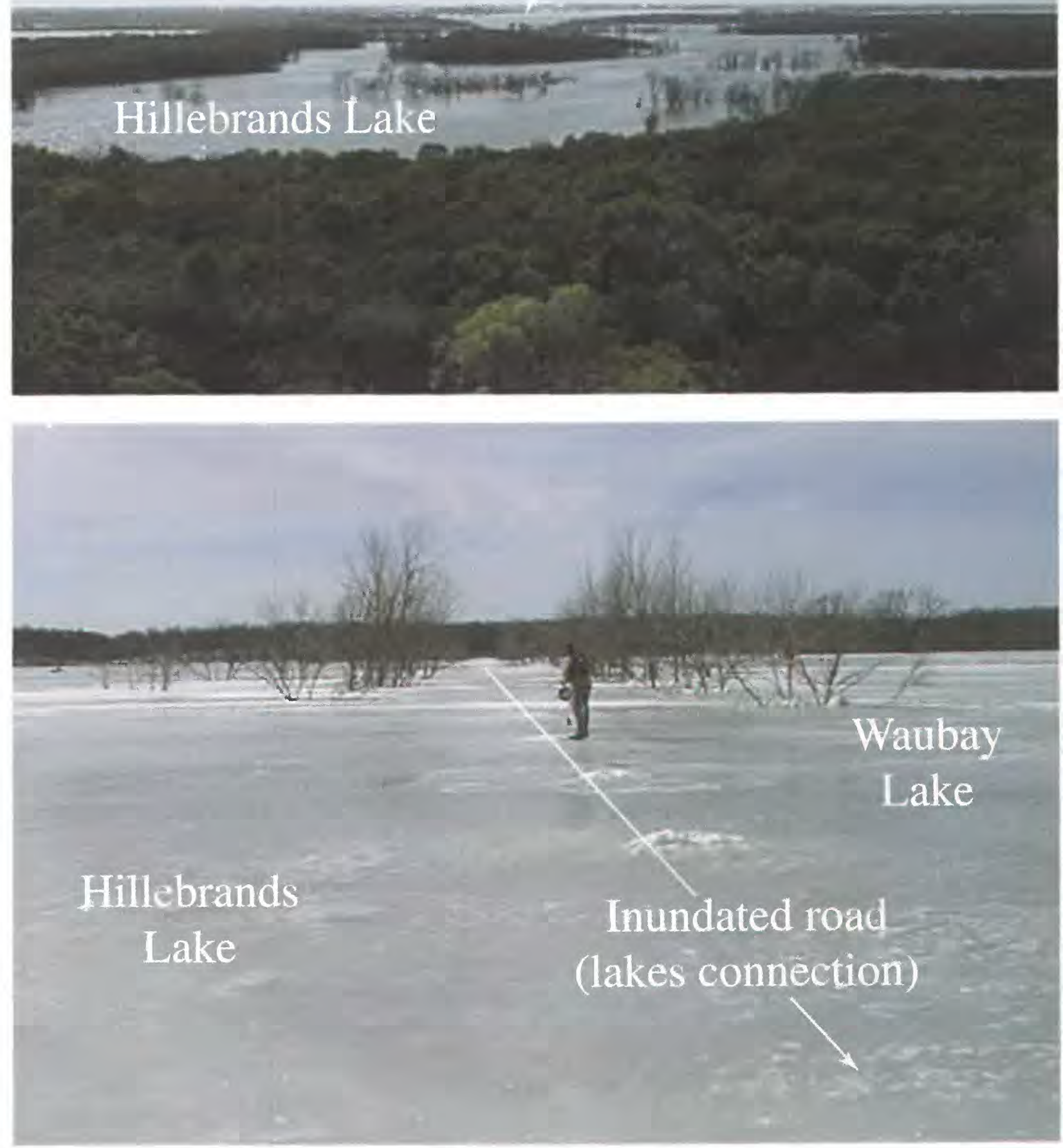

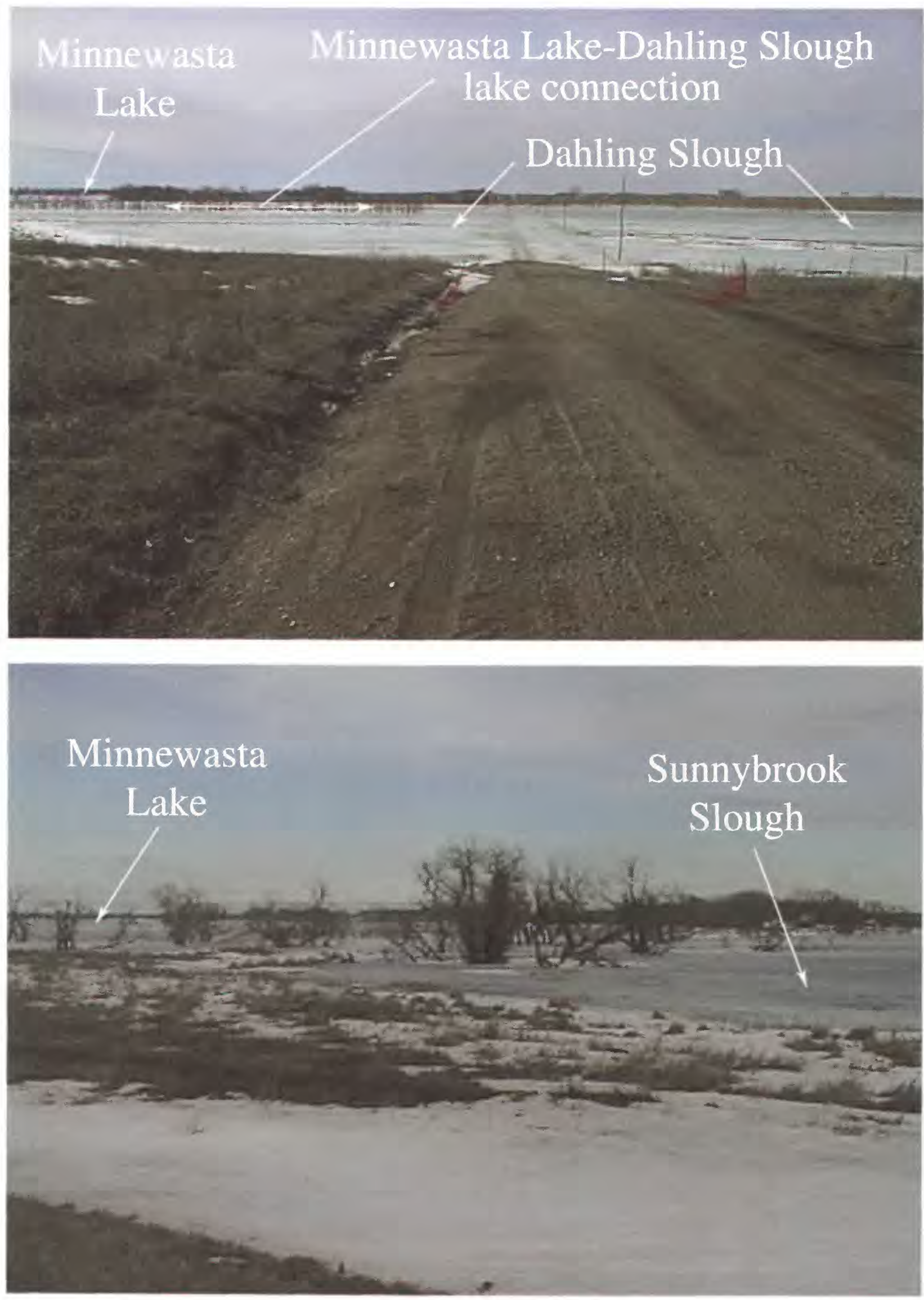

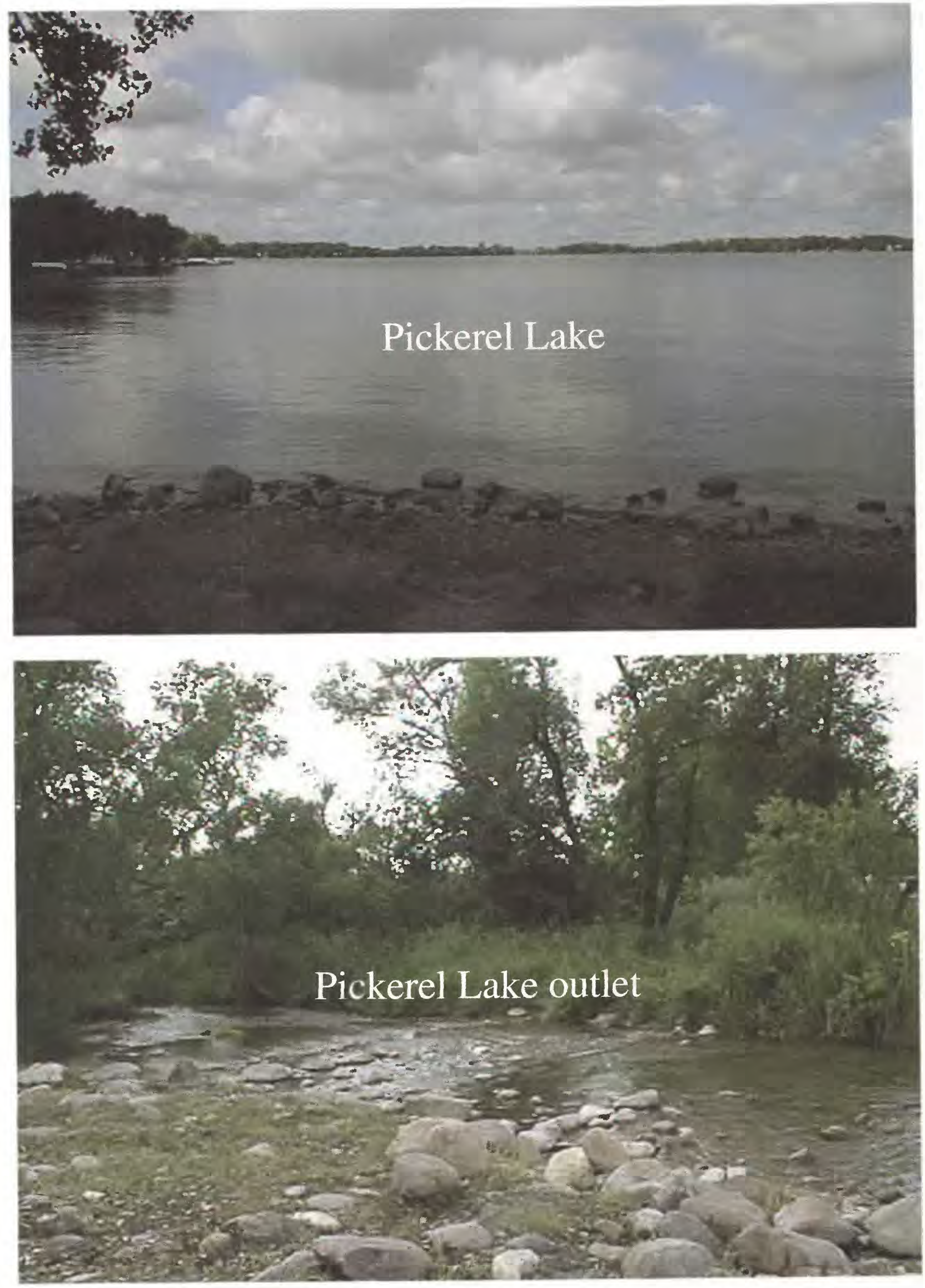


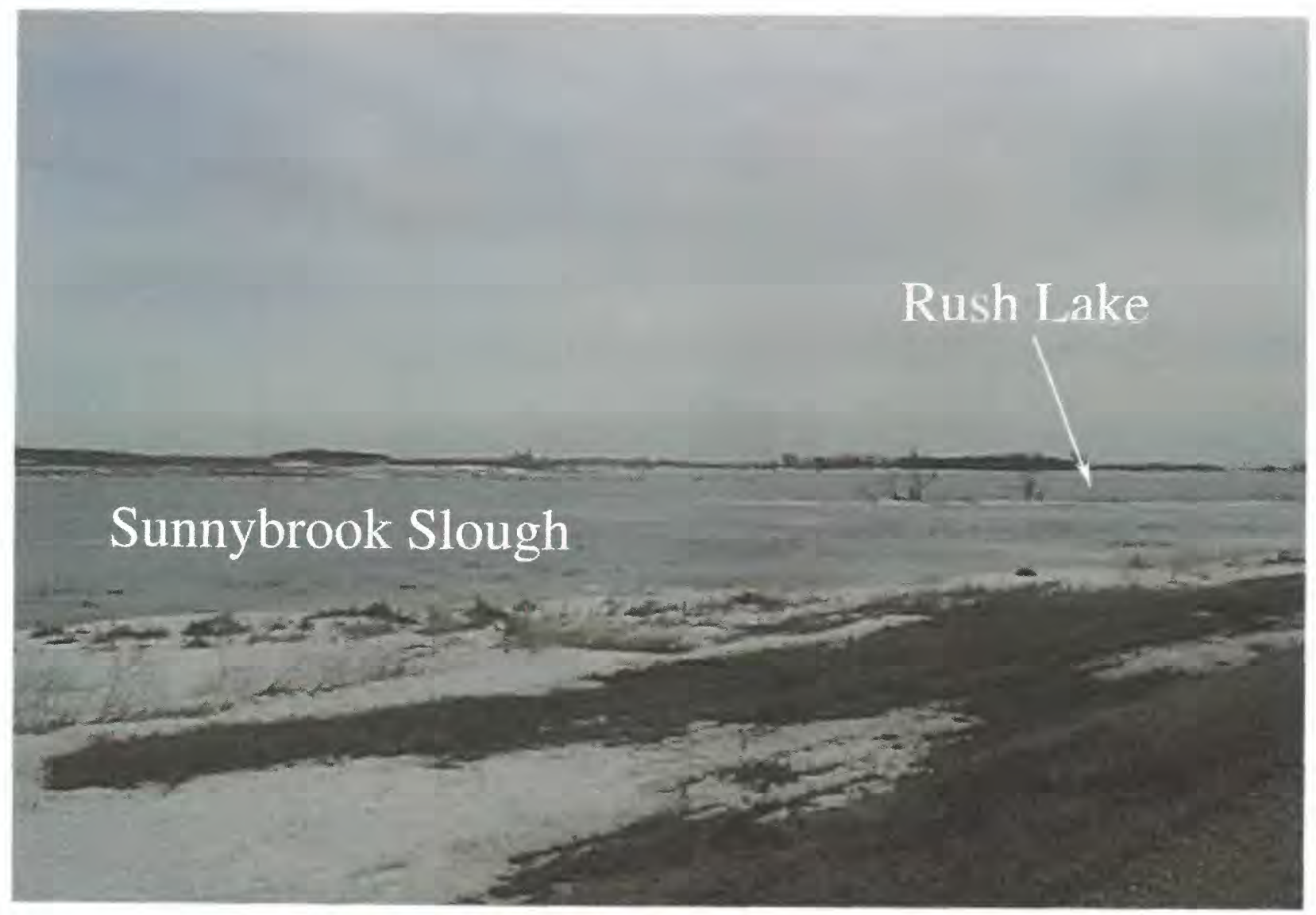

$r$

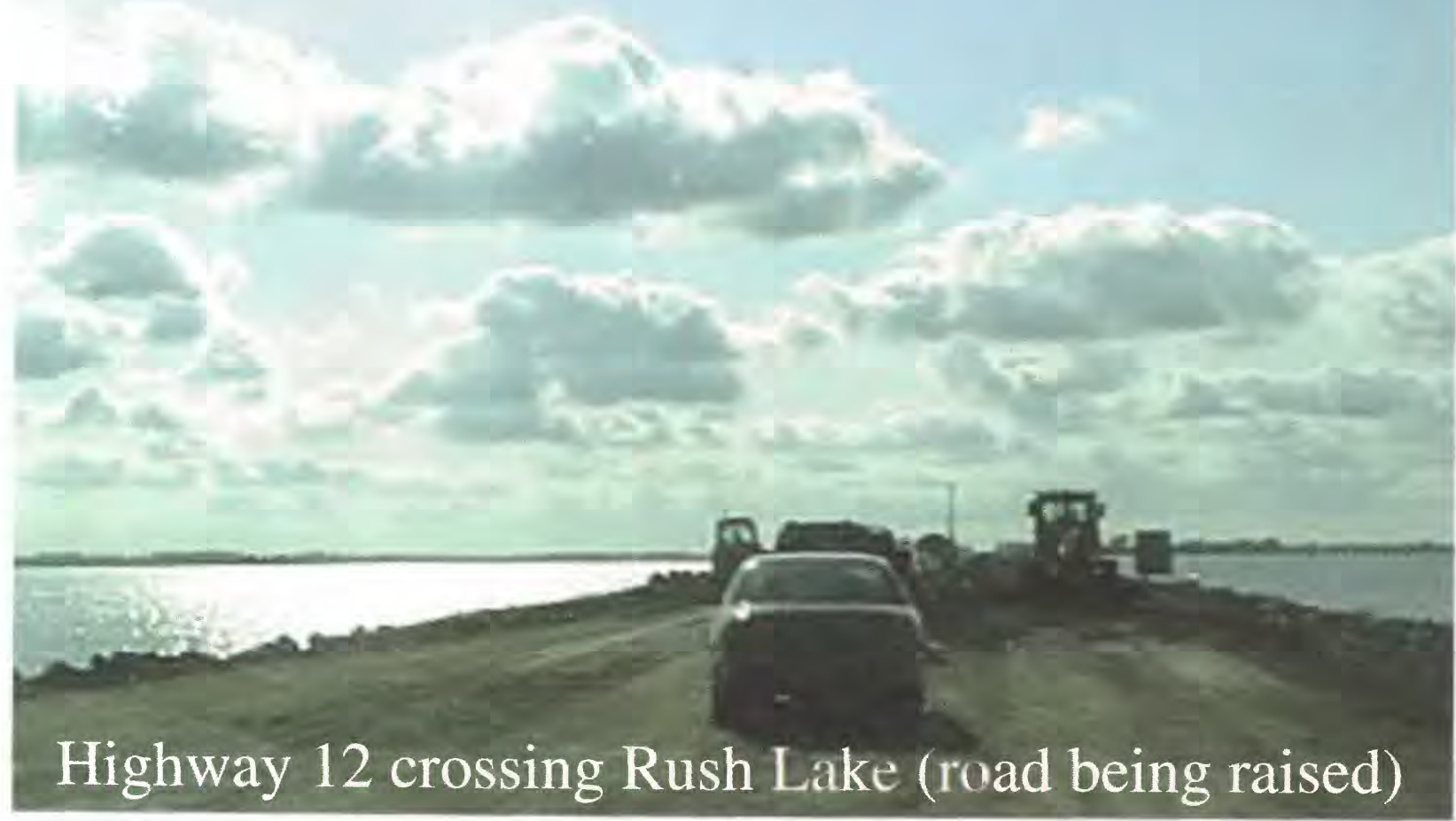




\section{Flowing over the outlet from Little Rush Lake}

\section{to Bitter Lake}
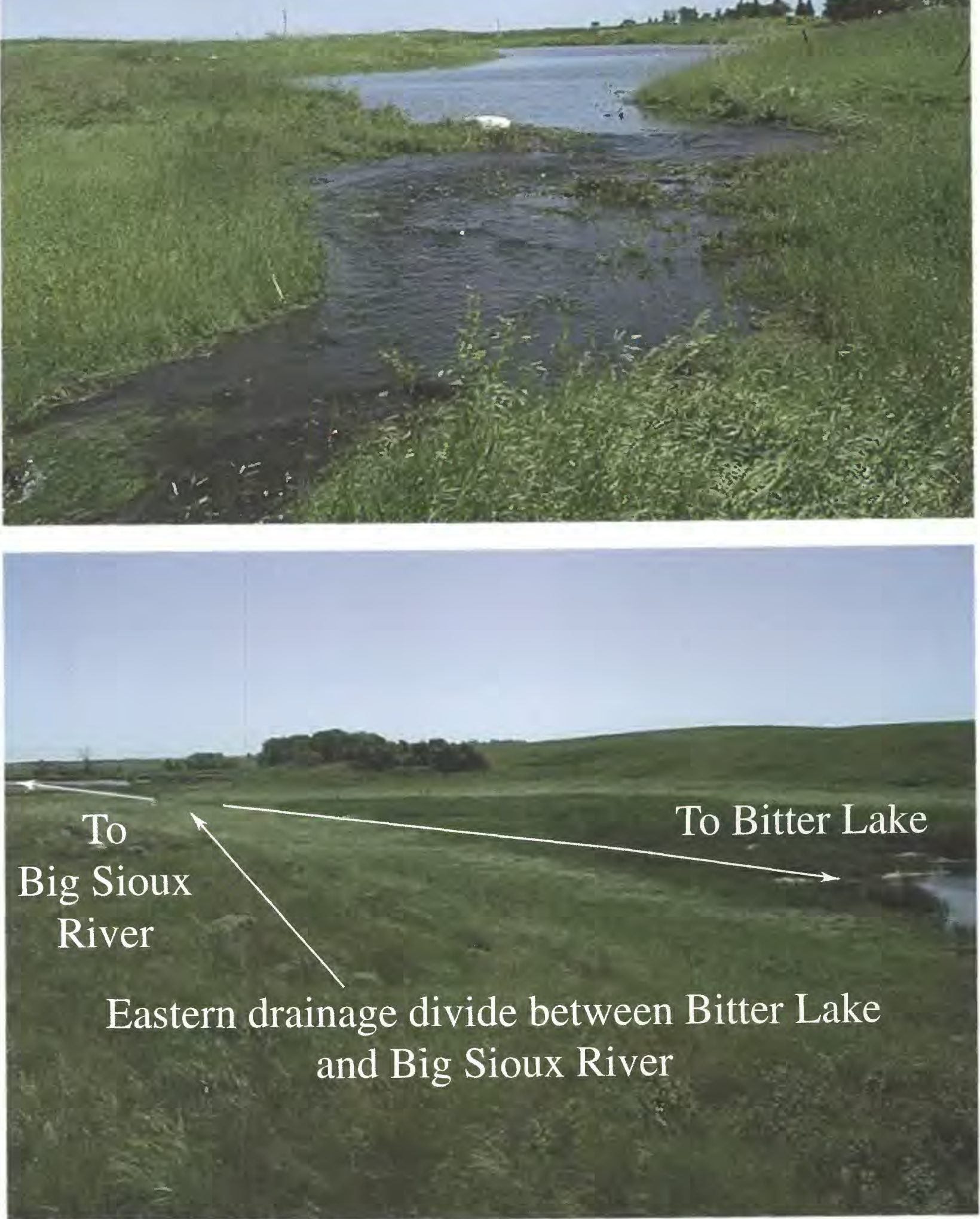

Section B - Tables 

Table B1. Historic lake levels for the 10 major lakes of the Waubay Lakes Chain

[Lake levels in feet above sea level; --, none]

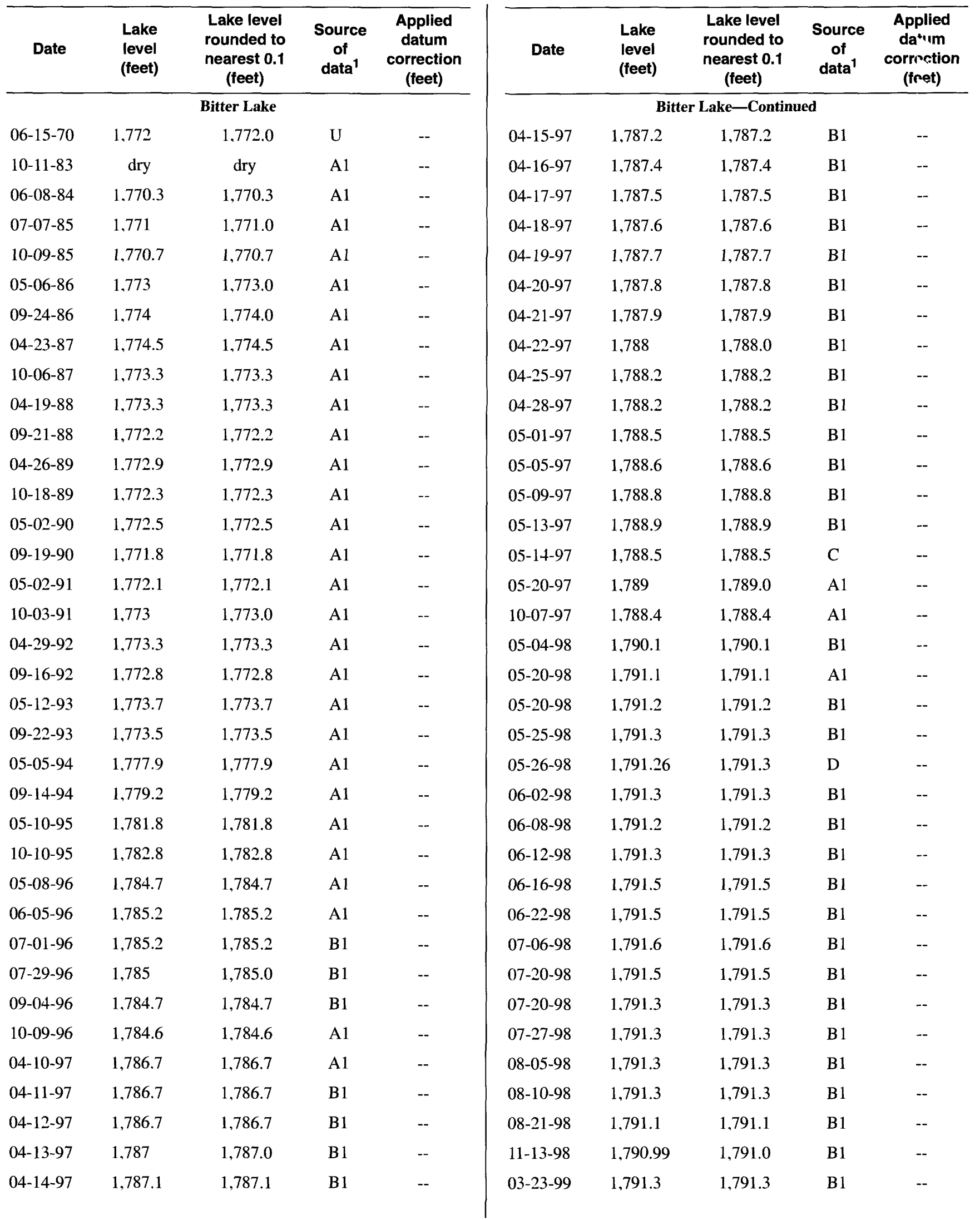


Table B1. Historic lake levels for the 10 major lakes of the Waubay Lakes Chain-Continued

[Lake levels in feet above sea level; --, none]

\begin{tabular}{|c|c|c|c|c|}
\hline Date & $\begin{array}{l}\text { Lake } \\
\text { level } \\
\text { (feet) }\end{array}$ & $\begin{array}{c}\text { Lake level } \\
\text { rounded to } \\
\text { nearest } 0.1 \\
\text { (feet) }\end{array}$ & $\begin{array}{c}\text { Source } \\
\text { of } \\
\text { data }^{1}\end{array}$ & $\begin{array}{l}\text { Applied } \\
\text { datum } \\
\text { correction } \\
\text { (feet) }\end{array}$ \\
\hline \multicolumn{5}{|c|}{ Bitter Lake-Continued } \\
\hline 04-07-99 & $1,791.47$ & $1,791.5$ & B1 & -- \\
\hline \multicolumn{5}{|c|}{ Blue Dog Lake } \\
\hline $06-15-33$ & $1,796.4$ & $1,796.4$ & $\mathrm{U}$ & 13.0 \\
\hline $08-01-34$ & $1,795.2$ & $1,795.2$ & $\mathrm{~A} 2$ & 13.0 \\
\hline $08-20-34$ & $1,795.7$ & $1,795.7$ & $\mathrm{E}$ & 13.0 \\
\hline $06-01-35$ & $1,796.7$ & $1,796.7$ & $\mathrm{E}$ & 13.0 \\
\hline $10-01-35$ & $1,794.3$ & $1,794.3$ & $\mathrm{~A} 2$ & 13.0 \\
\hline $10-19-35$ & $1,794.3$ & $1,794.3$ & $\mathrm{E}$ & 13.0 \\
\hline $05-01-36$ & $1,795.5$ & $1,795.5$ & $\mathrm{~A} 2$ & 13.0 \\
\hline $05-31-36$ & $1,795.5$ & $1,795.5$ & $\mathrm{E}$ & 13.0 \\
\hline $11-01-36$ & 1.794 .6 & $1,794.6$ & A2 & 13.0 \\
\hline $11-21-36$ & $1,794.6$ & $1,794.6$ & $\mathrm{E}$ & 13.0 \\
\hline $05-01-37$ & $1,799.3$ & $1,799.3$ & $\mathrm{~A} 2$ & 13.0 \\
\hline $05-29-37$ & $1,799.3$ & $1,799.3$ & $\mathrm{E}$ & 13.0 \\
\hline $10-01-37$ & 1.797 .2 & $1,797.2$ & $\mathrm{~A} 2$ & 13.0 \\
\hline $10-10-37$ & 1,797 & $1,797.0$ & $\mathrm{E}$ & 13.0 \\
\hline $06-01-38$ & 1,798 & $1,798.0$ & $\mathrm{~A} 2$ & 13.0 \\
\hline $06-11-38$ & 1,798 & $1,798.0$ & $\mathrm{E}$ & 13.0 \\
\hline $10-01-38$ & $1,797.2$ & $1,797.2$ & $\mathrm{~A} 2$ & 13.0 \\
\hline $10-09-38$ & $1,797.2$ & $1,797.2$ & $\mathrm{E}$ & 13.0 \\
\hline $05-01-39$ & $1,797.8$ & $1,797.8$ & $\mathrm{~A} 2$ & 13.0 \\
\hline $11-01-39$ & $1,796.9$ & $1,796.9$ & A2 & 13.0 \\
\hline $05-01-40$ & $1,798.4$ & $1,798.4$ & $\mathrm{~A} 2$ & 13.0 \\
\hline $05-16-40$ & $1,798.4$ & $1,798.4$ & $E$ & 13.0 \\
\hline $10-01-40$ & 1.797 .4 & $1,797.4$ & $\mathrm{~A} 2$ & 13.0 \\
\hline $10-25-40$ & $1,797.4$ & $1,797.4$ & $\mathrm{E}$ & 13.0 \\
\hline $06-01-41$ & $1,797.8$ & $1,797.8$ & $\mathrm{~A} 2$ & 13.0 \\
\hline $06-05-41$ & $1,797.8$ & $1,797.8$ & $\mathrm{E}$ & 13.0 \\
\hline $11-01-41$ & 1,797 & $1,797.0$ & $\mathrm{~A} 2$ & 13.0 \\
\hline $11-18-41$ & 1,797 & $1,797.0$ & $\mathrm{E}$ & 13.0 \\
\hline $05-01-42$ & $1,797.1$ & $1,797.1$ & $\mathrm{~A} 2$ & 13.0 \\
\hline $05-30-42$ & $1,797.1$ & $1,797.1$ & $\mathrm{E}$ & 13.0 \\
\hline $11-01-42$ & $1,798.2$ & $1,798.2$ & $\mathrm{~A} 2$ & 13.0 \\
\hline $11-03-42$ & $1,798.2$ & $1,798.2$ & $E$ & 13.0 \\
\hline $06-01-43$ & $1,797.9$ & $1,797.9$ & $\mathrm{~A} 2$ & 13.0 \\
\hline $06-17-43$ & 1.797 .9 & $1,797.9$ & $E$ & 13.0 \\
\hline
\end{tabular}

\begin{tabular}{|c|c|c|c|c|}
\hline Date & $\begin{array}{l}\text { Lake } \\
\text { level } \\
\text { (feet) }\end{array}$ & $\begin{array}{l}\text { Lake level } \\
\text { rounded to } \\
\text { nearest } 0.1 \\
\text { (feet) }\end{array}$ & $\begin{array}{c}\text { Source } \\
\text { of } \\
\text { data }^{1}\end{array}$ & $\begin{array}{l}\text { Applied } \\
\text { datum } \\
\text { correction } \\
\text { (feet) }\end{array}$ \\
\hline \multicolumn{5}{|c|}{ Blue Dog Lake-Continued } \\
\hline $11-01-43$ & $1,797.8$ & $1,797.8$ & $\mathrm{~A} 2$ & 13.0 \\
\hline $11-28-43$ & 1.797 .8 & $1,797.8$ & $\mathrm{E}$ & 13.0 \\
\hline $07-01-44$ & $1,797.8$ & $1,797.8$ & $\mathrm{~A} 2$ & 13.0 \\
\hline $07-05-44$ & $1,797.8$ & $1,797.8$ & $\mathrm{E}$ & 13.0 \\
\hline $11-01-44$ & $1,797.4$ & $1,797.4$ & $\mathrm{~A} 2$ & 13.0 \\
\hline $11-20-44$ & $1,797.4$ & $1,797.4$ & $\mathrm{E}$ & 13.0 \\
\hline $05-01-45$ & $1,797.9$ & $1,797.9$ & $\mathrm{~A} 2$ & 13.0 \\
\hline $05-06-45$ & $1,797.9$ & $1,797.9$ & $\mathrm{E}$ & 13.0 \\
\hline $10-01-45$ & $1,796.7$ & $1,796.7$ & $\mathrm{~A} 2$ & 13.0 \\
\hline $10-13-45$ & $1,796.7$ & $1,796.7$ & $\mathrm{E}$ & 13.0 \\
\hline 05-01-46 & 1.798 .9 & 1.798 .9 & $\mathrm{~A} 2$ & 13.0 \\
\hline $05-22-46$ & $1,798.9$ & $1,798.9$ & $\mathrm{E}$ & 13.0 \\
\hline $09-01-46$ & $1,797.7$ & $1,797.7$ & $\mathrm{~A} 2$ & 13.0 \\
\hline $09-30-46$ & $1,797.7$ & $1,797.7$ & $\mathrm{E}$ & 13.0 \\
\hline $05-01-47$ & $1,798.1$ & $1,798.1$ & $\mathrm{~A} 2$ & 13.0 \\
\hline $05-24-47$ & $1,798.1$ & $1,798.1$ & $\mathrm{E}$ & 13.0 \\
\hline $05-01-48$ & $1,797.9$ & $1,797.9$ & A2 & 13.0 \\
\hline $05-12-48$ & $1,797.9$ & $1,797.9$ & $\mathrm{E}$ & 13.0 \\
\hline $05-01-49$ & $1,797.8$ & $1,797.8$ & $\mathrm{~A} 2$ & 13.0 \\
\hline $05-19-49$ & $1,797.8$ & $1,797.8$ & $\mathrm{E}$ & 13.0 \\
\hline $11-01-49$ & $1,799.4$ & $1,799.4$ & $\mathrm{~A} 2$ & 13.0 \\
\hline $11-10-49$ & $1,799.4$ & $1,799.4$ & $\mathrm{E}$ & 13.0 \\
\hline $05-01-50$ & $1,800.5$ & $1,800.5$ & $\mathrm{~A} 2$ & 13.0 \\
\hline $05-16-50$ & $1,800.5$ & $1,800.5$ & $\mathrm{E}$ & 13.0 \\
\hline $01-01-51$ & 1,800 & $1,800.0$ & $\mathrm{~A} 2$ & 13.0 \\
\hline $01-08-51$ & 1,800 & $1,800.0$ & $\mathrm{E}$ & 13.0 \\
\hline $05-01-51$ & $1,800.5$ & $1,800.5$ & $\mathrm{~A} 2$ & 13.0 \\
\hline $05-07-51$ & $1,800.5$ & $1,800.5$ & $\mathrm{E}$ & 13.0 \\
\hline $02-01-52$ & $1,800.2$ & $1,800.2$ & $\mathrm{~A} 2$ & 13.0 \\
\hline $02-26-52$ & $1,800.2$ & $1,800.2$ & $\mathrm{E}$ & 13.0 \\
\hline $10-01-52$ & $1,799.6$ & $1,799.6$ & $\mathrm{~A} 2$ & 13.0 \\
\hline $11-01-53$ & $1,799.4$ & $1,799.4$ & $\mathrm{~A} 2$ & 13.0 \\
\hline $04-01-54$ & $1,801.5$ & $1,801.5$ & $\mathrm{~A} 2$ & 13.0 \\
\hline $09-01-54$ & $1,799.6$ & $1,799.6$ & $\mathrm{~A} 2$ & 13.0 \\
\hline $05-01-55$ & $1,800.3$ & $1,800.3$ & $\mathrm{~A} 2$ & 13.0 \\
\hline $05-01-56$ & $1,800.4$ & $1,800.4$ & $\mathrm{~A} 2$ & 13.0 \\
\hline
\end{tabular}


Table B1. Historic lake levels for the 10 major lakes of the Waubay Lakes Chain-Continued

[Lake levels in feet above sea level; --, none]

\begin{tabular}{|c|c|c|c|c|}
\hline Date & $\begin{array}{l}\text { Lake } \\
\text { level } \\
\text { (feet) }\end{array}$ & $\begin{array}{l}\text { Lake level } \\
\text { rounded to } \\
\text { nearest } 0.1 \\
\text { (feet) }\end{array}$ & $\begin{array}{c}\text { Source } \\
\text { of } \\
\text { data }^{1}\end{array}$ & $\begin{array}{l}\text { Applied } \\
\text { datum } \\
\text { correction } \\
\text { (feet) }\end{array}$ \\
\hline \multicolumn{5}{|c|}{ Blue Dog Lake-Continued } \\
\hline $11-01-56$ & $1,799.8$ & $1,799.8$ & $\mathrm{~A} 2$ & 13.0 \\
\hline $09-01-57$ & $1,799.9$ & $1,799.9$ & $\mathrm{E}$ & 13.0 \\
\hline 04-01-59 & $1,800.1$ & $1,800.1$ & $\mathrm{~A} 2$ & 13.0 \\
\hline 04-01-60 & $1,801.2$ & $1,801.2$ & A2 & 13.0 \\
\hline $06-01-61$ & $1,800.4$ & $1,800.4$ & A2 & 13.0 \\
\hline $06-05-61$ & $1,800.4$ & $1,800.4$ & $\mathrm{E}$ & 13.0 \\
\hline $12-01-61$ & $1,799.7$ & $1,799.7$ & $\mathrm{~A} 2$ & 13.0 \\
\hline $12-05-61$ & $1,799.7$ & $1,799.7$ & $\mathrm{E}$ & 13.0 \\
\hline $06-01-62$ & $1,800.9$ & $1,800.9$ & $\mathrm{~A} 2$ & 13.0 \\
\hline $06-07-62$ & $1,800.9$ & $1,800.9$ & $\mathrm{E}$ & 13.0 \\
\hline $12-01-62$ & $1,800.3$ & $1,800.3$ & $\mathrm{~A} 2$ & 13.0 \\
\hline $12-13-62$ & $1,800.3$ & $1,800.3$ & $\mathrm{E}$ & 13.0 \\
\hline $05-01-63$ & $1,800.5$ & $1,800.5$ & $\mathrm{~A} 2$ & 13.0 \\
\hline $06-09-63$ & $1,800.5$ & $1,800.5$ & $\mathrm{E}$ & 13.0 \\
\hline $09-17-63$ & $1,800.3$ & $1,800.3$ & E & 13.0 \\
\hline $05-01-64$ & $1,800.3$ & $1,800.3$ & $\mathrm{~A} 2$ & 13.0 \\
\hline $06-14-64$ & $1,800.3$ & $1,800.3$ & $\mathrm{E}$ & 13.0 \\
\hline $10-01-64$ & 1.800 .4 & $1,800.4$ & $\mathrm{~A} 2$ & 13.0 \\
\hline $10-15-64$ & $1,799.6$ & $1,799.6$ & $\mathrm{E}$ & 13.0 \\
\hline $05-01-66$ & $1,800.8$ & $1,800.8$ & $\mathrm{~A} 2$ & 13.0 \\
\hline $11-01-66$ & $1,800.3$ & $1,800.3$ & $\mathrm{~A} 2$ & 13.0 \\
\hline $05-01-67$ & $1,800.8$ & $1,800.8$ & $\mathrm{~A} 2$ & 13.0 \\
\hline $05-01-68$ & $1,800.7$ & $1,800.7$ & $\mathrm{~A} 2$ & 13.0 \\
\hline $11-01-68$ & $1,800.3$ & $1,800.3$ & $\mathrm{~A} 2$ & 13.0 \\
\hline $05-01-69$ & $1,800.3$ & $1,800.3$ & $\mathrm{~A} 2$ & 13.0 \\
\hline 09-01-69 & $1,799.6$ & $1,799.6$ & $\mathrm{~A} 2$ & 13.0 \\
\hline $05-01-70$ & 1.801 & $1,801.0$ & $\mathrm{~A} 2$ & 13.0 \\
\hline $12-01-70$ & $1,800.1$ & $1,800.1$ & $\mathrm{~A} 2$ & 13.0 \\
\hline $11-01-76$ & $1,798.3$ & $1,798.3$ & $\mathrm{~A} 2$ & 13.0 \\
\hline $02-21-80$ & $1,800.6$ & $1,800.6$ & B1 & -- \\
\hline $05-01-80$ & $1,800.1$ & $1,800.1$ & $\mathrm{~A} 2$ & -- \\
\hline $07-02-80$ & $1,800.2$ & $1,800.2$ & B1 & -- \\
\hline $07-07-80$ & 1,800 & $1,800.0$ & B1 & -- \\
\hline $07-22-80$ & $1,799.8$ & $1,799.8$ & B1 & -- \\
\hline $07-31-80$ & $1,799.7$ & $1,799.7$ & B1 & -- \\
\hline $11-01-80$ & $1,799.5$ & $1,799.5$ & $\mathrm{~A} 2$ & - \\
\hline
\end{tabular}

\begin{tabular}{|c|c|c|c|c|}
\hline Date & $\begin{array}{l}\text { Lake } \\
\text { level } \\
\text { (feet) }\end{array}$ & $\begin{array}{c}\text { Lake level } \\
\text { rounded to } \\
\text { nearest } 0.1 \\
\text { (feet) }\end{array}$ & $\begin{array}{c}\text { Source } \\
\text { of } \\
\text { data }^{1}\end{array}$ & $\begin{array}{l}\text { Aprlied } \\
\text { datum } \\
\text { corrertion } \\
\text { (fe?t) }\end{array}$ \\
\hline
\end{tabular}

Blue Dog Lake-Continued

$\begin{array}{lllll}11-04-80 & 1,799.5 & 1,799.5 & \text { B1 } & -- \\ 04-01-81 & 1,800.2 & 1,800.2 & \text { A2 } & -- \\ 04-02-81 & 1,800.2 & 1,800.2 & \text { B1 } & -- \\ 05-01-81 & 1,800.2 & 1,800.2 & \text { B1 } & -- \\ 05-01-83 & 1,800.2 & 1,800.2 & \text { A2 } & -- \\ 05-08-83 & 1,800.2 & 1,800.2 & \text { B1 } & -- \\ 10-01-83 & 1,799.7 & 1,799.7 & \text { A2 } & -- \\ 10-11-83 & 1,799.7 & 1,799.7 & \text { B1 } & - \\ 06-01-84 & 1,800.3 & 1,800.3 & \text { A2 } & -\end{array}$

06-08-84 $\quad 1,800.3 \quad 1,800.3 \quad$ B

08-01-84 1,800.2 $1,800.2 \quad$ A2

08-22-84 1,800.2 $\quad 1,800.2 \quad$ B 1

05-01-85 $\quad 1,800.3 \quad 1,800.3 \quad$ A2

05-07-85 $\quad 1,800.3 \quad 1,800.3 \quad$ B 1

$\begin{array}{llll}10-01-85 & 1,800.3 & 1,800.3 & \text { A2 }\end{array}$

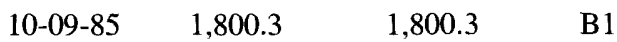

$\begin{array}{llll}05-01-86 & 1,800.7 & 1,800.7 & \text { A2 }\end{array}$

$\begin{array}{llll}05-06-86 & 1,800.7 & 1,800.7 & \text { B } 1\end{array}$

$\begin{array}{llll}09-01-86 & 1,800.8 & 1,800.8 & \text { A2 }\end{array}$

$\begin{array}{llll}09-24-86 & 1,800.8 & 1,800.8 & \text { B1 }\end{array}$

$\begin{array}{llll}04-01-87 & 1,800.6 & 1,800.6 & \text { A2 }\end{array}$

$\begin{array}{llll}04-22-87 & 1,800.6 & 1,800.6 & \text { B1 }\end{array}$

$\begin{array}{llll}10-01-87 & 1,800 & 1,800.0 & \text { A2 }\end{array}$

$\begin{array}{llll}10-06-87 & 1,800 & 1,800.0 & \text { B1 }\end{array}$

04-01-88 $\quad 1,800.2 \quad 1,800.2 \quad$ A2

04-19-88 $1,800.2 \quad 1,800.2 \quad$ B1

$\begin{array}{llll}09-01-88 & 1,799.2 & 1,799.2 & \text { A2 }\end{array}$

09-21-88 $1,799.2 \quad 1,799.2 \quad$ B1

$\begin{array}{llll}09-21-88 & 1,799.5 & 1,799.5 & \mathrm{H}\end{array}$

04-01-89 $1,800.2 \quad 1,800.2 \quad$ A2

04-26-89 $1,800.2 \quad 1,800.2 \quad$ B1

04-26-89 $1,800.5 \quad 1,800.5 \quad \mathrm{H}$

$\begin{array}{llll}10-01-89 & 1,799.8 & 1,799.8 & \text { A2 }\end{array}$

$\begin{array}{llll}10-18-89 & 1,799.8 & 1,799.8 & \text { B1 }\end{array}$

$10-18-89 \quad 1,800.1 \quad 1,800.1 \quad \mathrm{H}$

$\begin{array}{llll}05-01-90 & 1,800 & 1,800.0 & \text { A2 }\end{array}$ 
Table B1. Historic lake levels for the 10 major lakes of the Waubay Lakes Chain-Continued

[Lake levels in feet above sea level; --, none]

\begin{tabular}{|c|c|c|c|c|}
\hline Date & $\begin{array}{l}\text { Lake } \\
\text { level } \\
\text { (feet) }\end{array}$ & $\begin{array}{c}\text { Lake level } \\
\text { rounded to } \\
\text { nearest } 0.1 \\
\text { (feet) }\end{array}$ & $\begin{array}{c}\text { Source } \\
\text { of } \\
\text { data }^{1}\end{array}$ & $\begin{array}{l}\text { Applied } \\
\text { datum } \\
\text { correction } \\
\text { (feet) }\end{array}$ \\
\hline \multicolumn{5}{|c|}{ Blue Dog Lake-Continued } \\
\hline $05-02-90$ & 1.800 & $1,800.0$ & B1 & -- \\
\hline $05-02-90$ & $1,800.3$ & $1,800.3$ & $\mathbf{H}$ & -- \\
\hline $09-01-90$ & $1,799.7$ & $1,799.7$ & $\mathrm{~A} 2$ & -- \\
\hline $09-19-90$ & 1.799 .7 & $1,799.7$ & B1 & -- \\
\hline $09-19-90$ & 1,800 & $1,800.0$ & $\mathbf{H}$ & -- \\
\hline $05-01-91$ & 1.800 .3 & 1.800 .3 & $\mathrm{~A} 2$ & -- \\
\hline $05-01-91$ & $1,800.5$ & $1,800.5$ & $\mathrm{H}$ & -- \\
\hline $10-01-91$ & $1,800.1$ & $1,800.1$ & A2 & -- \\
\hline $10-03-91$ & $1,800.1$ & $1,800.1$ & B1 & -- \\
\hline $10-03-91$ & $1,800.3$ & $1,800.3$ & $\mathbf{H}$ & -- \\
\hline 04-01-92 & $1,800.3$ & $1,800.3$ & A2 & -- \\
\hline $04-29-92$ & $1,800.1$ & $1,800.1$ & B1 & -- \\
\hline $04-29-92$ & $1,800.4$ & $1,800.4$ & $\mathrm{H}$ & -- \\
\hline 09-01-92 & 1,800 & $1,800.0$ & A2 & -- \\
\hline $09-16-92$ & 1,800 & $1,800.0$ & B1 & -- \\
\hline $09-16-92$ & $1,800.3$ & $1,800.3$ & $\mathrm{H}$ & -- \\
\hline $05-01-93$ & 1.800 .3 & $1,800.3$ & $\mathrm{~A} 2$ & - \\
\hline $05-12-93$ & $1,800.3$ & $1,800.3$ & B 1 & -- \\
\hline $05-12-93$ & $1,800.6$ & $1,800.6$ & $\mathrm{H}$ & -- \\
\hline 09-01-93 & $1,800.5$ & $1,800.5$ & $\mathrm{~A} 2$ & -- \\
\hline $09-23-93$ & $1,800.5$ & $1,800.5$ & B1 & -- \\
\hline $09-23-93$ & $1,800.7$ & $1,800.7$ & $\mathrm{H}$ & -- \\
\hline $05-01-94$ & $1,800.7$ & $1,800.7$ & $\mathrm{~A} 2$ & -- \\
\hline $05-05-94$ & $1,800.7$ & $1,800.7$ & B1 & -- \\
\hline $05-05-94$ & 1,801 & $1,801.0$ & $\mathrm{H}$ & - \\
\hline $09-01-94$ & $1,800.2$ & $1,800.2$ & A2 & -- \\
\hline $09-14-94$ & $1,800.2$ & $1,800.2$ & B1 & -- \\
\hline $09-14-94$ & $1,800.4$ & $1,800.4$ & $\mathrm{H}$ & -- \\
\hline $05-01-95$ & $1,800.8$ & $1,800.8$ & A2 & -- \\
\hline $05-10-95$ & $1,800.8$ & $1,800.8$ & B1 & -- \\
\hline $05-10-95$ & $1,801.1$ & $1,801.1$ & $\mathrm{H}$ & - \\
\hline $10-01-95$ & $1,800.5$ & $1,800.5$ & $\mathrm{~A} 2$ & -- \\
\hline $10-10-95$ & $1,800.5$ & $1,800.5$ & B1 & -- \\
\hline $10-10-95$ & $1,800.7$ & $1,800.7$ & $\mathrm{H}$ & -- \\
\hline $05-01-96$ & $1,800.7$ & $1,800.7$ & $\mathrm{~A} 2$ & -- \\
\hline $05-08-96$ & $1,800.7$ & $1,800.7$ & B1 & -- \\
\hline
\end{tabular}

\begin{tabular}{|c|c|c|c|c|}
\hline Date & $\begin{array}{l}\text { Lake } \\
\text { level } \\
\text { (feet) }\end{array}$ & $\begin{array}{l}\text { Lake level } \\
\text { rounded to } \\
\text { nearest } 0.1 \\
\text { (feet) }\end{array}$ & $\begin{array}{c}\text { Sourise } \\
\text { of } \\
\text { data }^{1}\end{array}$ & $\begin{array}{c}\text { Applied } \\
\text { datum } \\
\text { correction } \\
\text { (feet) }\end{array}$ \\
\hline
\end{tabular}

Blue Dog Lake-Continued

$\begin{array}{llll}05-08-96 & 1,801 & 1,801.0 & \mathrm{H}\end{array}$

06-04-96 $1.800 .7 \quad 1,800.7 \quad$ B1

06-04-96 $1,801 \quad 1,801.0 \quad \mathrm{H}$

$\begin{array}{llll}07-01-96 & 1,800.3 & 1,800.3 & \text { B1 }\end{array}$

$\begin{array}{llll}07-01-96 & 1,800.6 & 1,800.6 & \text { H }\end{array}$

$\begin{array}{llll}07-29-96 & 1,800.1 & 1,800.1 & \text { B1 }\end{array}$

$\begin{array}{llll}07-29-96 & 1,800.3 & 1,800.3 & \mathrm{H}\end{array}$

$\begin{array}{llll}09-01-96 & 1,800 & 1,800.0 & \text { A2 }\end{array}$

$\begin{array}{llll}09-04-96 & 1,800 & 1,800.0 & \mathrm{~B} 1\end{array}$

$\begin{array}{llll}09-04-96 & 1,800.3 & 1,800.3 & \text { H }\end{array}$

$\begin{array}{llll}10-09-96 & 1,800.1 & 1,800.1 & \text { B1 }\end{array}$

$\begin{array}{llll}10-09-96 & 1,800.3 & 1,800.3 & \mathrm{H}\end{array}$

$\begin{array}{llll}04-07-97 & 1,802.3 & 1,802.3 & \text { A2 }\end{array}$

04-10-97 $1,801.9 \quad 1,801.9 \quad$ B1

$\begin{array}{llll}04-11-97 & 1,802.2 & 1,802.2 & \text { B1 }\end{array}$

$\begin{array}{llll}04-12-97 & 1,802.1 & 1,802.1 & \text { B1 }\end{array}$

$\begin{array}{llll}04-13-97 & 1,801.8 & 1,801.8 & \text { B1 }\end{array}$

$\begin{array}{llll}04-14-97 & 1,801.7 & 1,801.7 & \text { B1 }\end{array}$

04-15-97 $1,801.5 \quad 1,801.5 \quad$ B1

04-16-97 $1.801 .5 \quad 1,801.5 \quad$ B1

$\begin{array}{llll}04-17-97 & 1,801.7 & 1,801.7 & \text { B1 }\end{array}$

$\begin{array}{llll}04-18-97 & 1,801.8 & 1,801.8 & \text { B1 }\end{array}$

$\begin{array}{llll}04-19-97 & 1,802 & 1,802.0 & \text { B1 }\end{array}$

$\begin{array}{llll}04-20-97 & 1,802.1 & 1,802.1 & \text { B1 }\end{array}$

$\begin{array}{llll}04-21-97 & 1,802.1 & 1,802.1 & \text { B1 }\end{array}$

$\begin{array}{llll}04-22-97 & 1,802.2 & 1,802.2 & \text { B1 }\end{array}$

$\begin{array}{llll}04-25-97 & 1.802 & 1,802.0 & \text { B1 }\end{array}$

$\begin{array}{llll}04-28-97 & 1,801.8 & 1,801.8 & \text { B1 }\end{array}$

$\begin{array}{llll}05-01-97 & 1,801.6 & 1,801.6 & \text { B1 }\end{array}$

$\begin{array}{llll}05-09-97 & 1,801.4 & 1,801.4 & \text { B1 }\end{array}$

$\begin{array}{llll}05-13-97 & 1,801.2 & 1,801.2 & \text { B1 }\end{array}$

$\begin{array}{llll}05-16-97 & 1,800.58 & 1,800.6 & C\end{array}$

$\begin{array}{llll}05-20-97 & 1,801 & 1,801.0 & \text { B1 }\end{array}$

$\begin{array}{llll}10-01-97 & 1,800.5 & 1,800.5 & \text { A2 }\end{array}$

$\begin{array}{llll}10-07-97 & 1,800 & 1,800.0 & \text { B1 }\end{array}$

$\begin{array}{llll}03-01-98 & 1,800.9 & 1,800.9 & \text { A2 }\end{array}$ 
Table B1. Historic lake levels for the 10 major lakes of the Waubay Lakes Chain-Continued

[Lake levels in feet above sea level; --, none]

\begin{tabular}{|c|c|c|c|c|c|c|c|c|c|}
\hline Date & $\begin{array}{l}\text { Lake } \\
\text { level } \\
\text { (feet) }\end{array}$ & $\begin{array}{l}\text { Lake level } \\
\text { rounded to } \\
\text { nearest } 0.1 \\
\text { (feet) }\end{array}$ & $\begin{array}{c}\text { Source } \\
\text { of } \\
\text { data }^{1}\end{array}$ & $\begin{array}{c}\text { Applied } \\
\text { datum } \\
\text { correction } \\
\text { (feet) }\end{array}$ & Date & $\begin{array}{l}\text { Lake } \\
\text { level } \\
\text { (feet) }\end{array}$ & $\begin{array}{l}\text { Lake level } \\
\text { rounded to } \\
\text { nearest } 0.1 \\
\text { (feet) }\end{array}$ & $\begin{array}{c}\text { Source } \\
\text { of } \\
\text { data }^{1}\end{array}$ & $\begin{array}{l}\text { Applied } \\
\text { dat um } \\
\text { corre?tion } \\
\text { (fe }: t)\end{array}$ \\
\hline \multicolumn{5}{|c|}{ Blue Dog Lake-Continued } & \multicolumn{5}{|c|}{ Enemy Swim Lake-Continued } \\
\hline 04-01-98 & 1,802 & $1,802.0$ & $\mathrm{U}$ & -- & $10-01-35$ & $1,840.1$ & $1,840.1$ & $\mathrm{~A} 2$ & -- \\
\hline 05-01-98 & $1,802.9$ & $1,802.9$ & $\mathrm{U}$ & -- & $10-19-35$ & $1,840.1$ & $1,840.1$ & $\mathrm{E}$ & 19.1 \\
\hline 05-04-98 & $1,802.1$ & $1,802.1$ & B1 & -- & $04-01-36$ & $1,840.2$ & $1,840.2$ & $\mathrm{~A} 2$ & -- \\
\hline 05-20-98 & $1,802.87$ & $1,802.9$ & B1 & -- & $05-30-36$ & $1,840.2$ & $1,840.2$ & $\mathrm{E}$ & 19.1 \\
\hline $05-25-98$ & $1,802.9$ & $1,802.9$ & B1 & -- & $11-01-36$ & $1,838.1$ & $1,838.1$ & A2 & -- \\
\hline $05-26-98$ & $1,802.88$ & $1,802.9$ & B1 & -- & $11-21-36$ & $1,838.1$ & $1,838.1$ & $\mathrm{E}$ & 19.1 \\
\hline 05-29-98 & $1,802.9$ & $1,802.9$ & B1 & -- & $05-01-37$ & $1,841.9$ & 1.841 .9 & A2 & -- \\
\hline 06-02-98 & $1,802.9$ & $1,802.9$ & B1 & -- & $05-30-37$ & $1,841.9$ & $1,841.9$ & $\mathrm{E}$ & 19.1 \\
\hline $06-08-98$ & $1,802.7$ & $1,802.7$ & B1 & -- & $10-01-37$ & $1,840.9$ & $1,840.9$ & $\mathrm{~A} 2$ & -- \\
\hline 06-15-98 & 1,803 & $1,803.0$ & B1 & -- & $10-09-37$ & $1,840.9$ & $1,840.9$ & $\mathrm{E}$ & 19.1 \\
\hline $06-16-98$ & 1,803 & $1,803.0$ & B1 & -- & $06-01-38$ & $1,841.1$ & $1,841.1$ & A2 & -- \\
\hline $06-22-98$ & 1,803 & $1,803.0$ & B1 & -- & $06-11-38$ & $1,840.6$ & $1,840.6$ & $\mathrm{E}$ & 19.1 \\
\hline 06-29-98 & $1,803.1$ & $1,803.1$ & B1 & -- & $10-01-38$ & $1,840.2$ & $1,840.2$ & $\mathrm{~A} 2$ & -- \\
\hline $07-06-98$ & 1,803 & $1,803.0$ & B1 & -- & $10-08-38$ & $1,840.2$ & $1,840.2$ & E & 19.1 \\
\hline $07-20-98$ & 1.803 & 1.803 .0 & B1 & -- & 05-01-39 & $1,841.5$ & $1,841.5$ & $\mathrm{~A} 2$ & -- \\
\hline $07-27-98$ & $1,802.8$ & $1,802.8$ & B1 & -- & $05-29-39$ & $1,841.52$ & $1,841.5$ & E & 19.1 \\
\hline 08-05-98 & 1.802 .9 & $1,802.9$ & B1 & -- & $11-01-39$ & $1,839.6$ & $1,839.6$ & A2 & -- \\
\hline $08-10-98$ & $1,802.8$ & $1,802.8$ & B1 & -- & $11-18-39$ & $1,839.61$ & $1,839.6$ & E & 19.1 \\
\hline 08-21-98 & $1,802.6$ & $1,802.6$ & B1 & -- & $05-01-40$ & $1,840.3$ & $1,840.3$ & $\mathrm{~A} 2$ & -- \\
\hline $08-25-98$ & $1,802.6$ & $1,802.6$ & B1 & -- & $05-16-40$ & $1,840.31$ & $1,840.3$ & $\mathrm{E}$ & 19.1 \\
\hline 08-28-98 & $1,802.7$ & $1,802.7$ & B1 & -- & $10-01-40$ & 1,838 & $1,838.0$ & $\mathrm{~A}_{2}$ & -- \\
\hline 09-04-98 & 1.802 .5 & $1,802.5$ & B1 & -- & $10-25-40$ & $1,837.95$ & 1.838 .0 & $\mathrm{E}$ & 19.1 \\
\hline $11-13-98$ & $1,802.73$ & 1.802 .7 & B1 & -- & $06-01-41$ & $1,840.4$ & $1,840.4$ & $\mathrm{~A} 2$ & -- \\
\hline 03-23-99 & $1,803.3$ & $1,803.3$ & B1 & -- & $06-04-41$ & $1,840.36$ & $1,840.4$ & $\mathrm{E}$ & 19.1 \\
\hline 04-07-99 & $1,803.55$ & $1,803.6$ & B1 & -- & $11-01-41$ & $1,840.2$ & $1,840.2$ & A2 & -- \\
\hline \multicolumn{5}{|c|}{ Enemy Swim Lake } & $11-18-41$ & $1,840.17$ & $1,840.2$ & $\mathrm{E}$ & 19.1 \\
\hline $06-15-25$ & $1,848.3$ & $1,848.3$ & F3 & -- & $05-01-42$ & $1,841.5$ & $1,841.5$ & $\mathrm{~A} 2$ & -- \\
\hline $06-15-27$ & 1.849 .7 & $1,849.7$ & F3 & -- & $05-30-42$ & $1,841.55$ & $1,841.6$ & $\mathrm{E}$ & 19.1 \\
\hline $06-15-31$ & 1.844 .7 & $1,844.7$ & F3 & -- & $11-01-42$ & $1,840.5$ & $1,840.5$ & $\mathrm{~A} 2$ & -- \\
\hline 08-01-33 & 1.843 & $1,843.0$ & A2 & -- & $11-03-42$ & $1,840.51$ & $1,840.5$ & $\mathrm{E}$ & 19.1 \\
\hline 07-01-34 & $1,841.7$ & $1,841.7$ & A2 & -- & $06-01-43$ & $1,845.8$ & 1.845 .8 & $\mathrm{~A} 2$ & -- \\
\hline $07-12-34$ & $1,841.7$ & $1,841.7$ & $\mathrm{E}$ & 19.1 & $06-17-43$ & $1,845.8$ & $1,845.8$ & $\mathrm{E}$ & 19.1 \\
\hline 08-01-34 & $1,841.1$ & $1,841.1$ & A2 & -- & $11-01-43$ & $1,845.4$ & $1,845.4$ & $\mathrm{~A} 2$ & -- \\
\hline $08-10-34$ & $1,841.1$ & $1,841.1$ & $\mathrm{E}$ & 19.1 & $11-28-43$ & $1,845.4$ & $1,845.4$ & $\mathrm{E}$ & 19.1 \\
\hline 08-30-34 & $1,841.05$ & $1,841.1$ & $\mathrm{E}$ & 19.1 & $07-01-44$ & $1,846.7$ & $1,846.7$ & $\mathrm{~A} 2$ & -- \\
\hline $05-31-35$ & $1,841.4$ & $1,841.4$ & $\mathrm{E}$ & 19.1 & $07-05-44$ & $1,846.71$ & $1,846.7$ & $\mathrm{E}$ & 19.1 \\
\hline
\end{tabular}


Table B1. Historic lake levels for the 10 major lakes of the Waubay Lakes Chain-Continued [Lake levels in feet above sea level; --, none]

\begin{tabular}{|c|c|c|c|c|}
\hline Date & $\begin{array}{l}\text { Lake } \\
\text { level } \\
\text { (feet) }\end{array}$ & $\begin{array}{c}\text { Lake level } \\
\text { rounded to } \\
\text { nearest } 0.1 \\
\text { (feet) }\end{array}$ & $\begin{array}{c}\text { Source } \\
\text { of } \\
\text { data }^{1}\end{array}$ & $\begin{array}{l}\text { Applied } \\
\text { datum } \\
\text { correction } \\
\text { (feet) }\end{array}$ \\
\hline \multicolumn{5}{|c|}{ Enemy Swim Lake-Continued } \\
\hline $11-01-44$ & $1,846.9$ & $1,846.9$ & $\mathrm{~A} 2$ & -- \\
\hline $11-20-44$ & $1,846.93$ & $1,846.9$ & $\mathrm{E}$ & 19.1 \\
\hline $05-01-45$ & $1,848.1$ & $1,848.1$ & $\mathrm{~A} 2$ & -- \\
\hline $05-06-45$ & $1,848.07$ & $1,848.1$ & $\mathrm{E}$ & 19.1 \\
\hline $10-01-45$ & $1,851.4$ & $1,851.4$ & $\mathrm{~A} 2$ & -- \\
\hline $10-13-45$ & $1,851.36$ & $1,851.4$ & $\mathrm{E}$ & 19.1 \\
\hline $05-01-46$ & 1,850 & $1,850.0$ & $\mathrm{~A} 2$ & -- \\
\hline $05-23-46$ & $1,850.01$ & $1,850.0$ & $\mathrm{E}$ & 19.1 \\
\hline $09-01-46$ & $1,849.5$ & 1.849 .5 & A2 & -- \\
\hline $09-30-46$ & $1,849.48$ & $1,849.5$ & $\mathrm{E}$ & 19.1 \\
\hline $05-01-47$ & $1,851.9$ & $1,851.9$ & $\mathrm{~A} 2$ & -- \\
\hline $05-24-47$ & $1,851.94$ & $1,851.9$ & $\mathrm{E}$ & 19.1 \\
\hline $05-01-48$ & $1,852.3$ & 1.852 .3 & A2 & -- \\
\hline $05-12-48$ & $1,851.86$ & $1,851.9$ & $\mathrm{E}$ & 19.1 \\
\hline $05-01-49$ & $1,849.4$ & $1,849.4$ & $\mathrm{~A} 2$ & -- \\
\hline $05-19-49$ & $1,849.41$ & $1,849.4$ & $\mathrm{E}$ & 19.1 \\
\hline $11-01-49$ & $1,849.5$ & $1,849.5$ & $\mathrm{~A} 2$ & -- \\
\hline $11-12-49$ & $1,849.46$ & $1,849.5$ & $\mathrm{E}$ & 19.1 \\
\hline $05-01-50$ & $1,851.2$ & $1,851.2$ & A2 & -- \\
\hline $05-16-50$ & $1,851.2$ & $1,851.2$ & $\mathrm{E}$ & 19.1 \\
\hline $01-01-51$ & $1,849.8$ & $1,849.8$ & $\mathrm{~A} 2$ & -- \\
\hline $01-08-51$ & $1,849.84$ & $1,849.8$ & $\mathrm{E}$ & 19.1 \\
\hline $05-01-51$ & $1,851.2$ & $1,851.2$ & $\mathrm{~A} 2$ & - \\
\hline $05-07-51$ & $1,851.17$ & $1,851.2$ & $\mathrm{E}$ & 19.1 \\
\hline $02-01-52$ & $1,850.9$ & $1,850.9$ & $\mathrm{~A} 2$ & -- \\
\hline $02-26-52$ & $1,850.89$ & $1,850.9$ & $\mathrm{E}$ & 19.1 \\
\hline $05-01-52$ & $1,853.9$ & $1,853.9$ & $\mathrm{~A} 2$ & -- \\
\hline $10-01-52$ & 1,852 & $1,852.0$ & $\mathrm{~A} 2$ & -- \\
\hline $11-01-53$ & $1,852.1$ & $1,852.1$ & $\mathrm{~A} 2$ & -- \\
\hline $04-01-54$ & $1,852.8$ & $1,852.8$ & $\mathrm{~A} 2$ & -- \\
\hline $09-01-54$ & $1,852.4$ & $1,852.4$ & $\mathrm{~A} 2$ & - \\
\hline $05-01-55$ & $1,852.1$ & $1,852.1$ & $\mathrm{~A} 2$ & -- \\
\hline $05-01-56$ & $1,851.3$ & $1,851.3$ & $\mathrm{~A} 2$ & -- \\
\hline $11-01-56$ & $1,849.9$ & $1,849.9$ & $\mathrm{~A} 2$ & -- \\
\hline $09-01-57$ & $1,850.5$ & $1,850.5$ & A2 & - \\
\hline $04-01-60$ & $1,849.1$ & $1,849.1$ & $\mathrm{~A} 2$ & -- \\
\hline
\end{tabular}

\begin{tabular}{|c|c|c|c|c|}
\hline Date & $\begin{array}{l}\text { Lake } \\
\text { level } \\
\text { (feet) }\end{array}$ & $\begin{array}{c}\text { Lake level } \\
\text { rounded to } \\
\text { nearest } 0.1 \\
\text { (feet) }\end{array}$ & $\begin{array}{c}\text { Sourise } \\
\text { of } \\
\text { data }^{1}\end{array}$ & $\begin{array}{c}\text { Applied } \\
\text { datum } \\
\text { correction } \\
\text { (feet) }\end{array}$ \\
\hline \multicolumn{5}{|c|}{ Enemy Swim Lake_Continued } \\
\hline $06-01-61$ & $1,847.9$ & $1,847.9$ & $\mathrm{~A} 2$ & -- \\
\hline $06-06-61$ & 1.847 .9 & $1,847.9$ & $\mathrm{E}$ & 19.1 \\
\hline $12-01-61$ & $1,846.9$ & $1,846.9$ & A2 & -- \\
\hline $12-05-61$ & $1,846.9$ & $1,846.9$ & $\mathrm{E}$ & 19.1 \\
\hline $06-01-62$ & $1,849.7$ & $1,849.7$ & A2 & -- \\
\hline $06-07-62$ & $1,849.7$ & $1,849.7$ & $\mathrm{E}$ & 19.1 \\
\hline $12-01-62$ & $1,850.8$ & $1,850.8$ & A2 & -- \\
\hline $12-13-62$ & $1,850.8$ & $1,850.8$ & $\mathrm{E}$ & 19.1 \\
\hline $05-01-63$ & $1,851.1$ & $1,851.1$ & $\mathrm{~A} 2$ & -- \\
\hline $05-09-63$ & 1,851 & $1,851.0$ & $\mathrm{E}$ & 19.1 \\
\hline $09-17-63$ & $1,851.9$ & $1,851.9$ & $\mathrm{E}$ & 19.1 \\
\hline $05-01-64$ & $1,851.7$ & $1,851.7$ & A2 & -- \\
\hline $05-14-64$ & $1,851.7$ & $1,851.7$ & $\mathrm{E}$ & 19.1 \\
\hline $10-15-64$ & $1,850.5$ & $1,850.5$ & $E$ & 19.1 \\
\hline $05-01-66$ & $1,852.3$ & $1,852.3$ & A2 & -- \\
\hline $05-05-66$ & $1,852.2$ & $1,852.2$ & $\mathrm{E}$ & 19.1 \\
\hline $11-01-66$ & $1,851.3$ & $1,851.3$ & A2 & -- \\
\hline $11-11-66$ & $1,851.2$ & $1,851.2$ & $\mathrm{E}$ & 19.1 \\
\hline $05-01-67$ & 1,852 & $1,852.0$ & A2 & -- \\
\hline $05-17-67$ & $1,851.9$ & $1,851.9$ & $\mathrm{E}$ & 19.1 \\
\hline $05-01-68$ & $1,850.4$ & $1,850.4$ & $\mathrm{~A} 2$ & -- \\
\hline $05-02-68$ & $1,850.4$ & $1,850.4$ & $\mathrm{E}$ & 19.1 \\
\hline $11-01-68$ & $1,849.6$ & $1,849.6$ & A2 & -- \\
\hline $11-12-68$ & $1,849.5$ & $1,849.5$ & $\mathrm{E}$ & 19.1 \\
\hline $05-01-69$ & $1,852.5$ & $1,852.5$ & A2 & -- \\
\hline $05-19-69$ & $1,852.5$ & $1,852.5$ & $\mathrm{E}$ & 19.1 \\
\hline $10-23-69$ & $1,851.3$ & $1,851.3$ & $\mathrm{E}$ & 19.1 \\
\hline $11-01-69$ & $1,851.4$ & $1,851.4$ & $\mathrm{~A} 2$. & -- \\
\hline $05-01-70$ & $1,853.2$ & $1,853.2$ & A2 & -- \\
\hline $05-13-70$ & $1,853.1$ & $1,853.1$ & $\mathrm{E}$ & 19.1 \\
\hline $12-01-70$ & 1,851 & $1,851.0$ & $\mathrm{~A} 2$ & -- \\
\hline $12-13-70$ & $1,851.2$ & $1,851.2$ & $\mathrm{E}$ & 19.1 \\
\hline $10-13-72$ & 1,853 & $1,853.0$ & $\mathrm{E}$ & 19.1 \\
\hline $10-28-72$ & $1,852.6$ & $1,852.6$ & $\mathrm{E}$ & 19.1 \\
\hline $05-01-75$ & $1,852.5$ & $1,852.5$ & $\mathrm{~A} 2$. & -- \\
\hline $11-01-76$ & $1,847.2$ & $1,847.2$ & A2. & -- \\
\hline
\end{tabular}


Table B1. Historic lake levels for the 10 major lakes of the Waubay Lakes Chain-Continued

[Lake levels in feet above sea level; --, none]

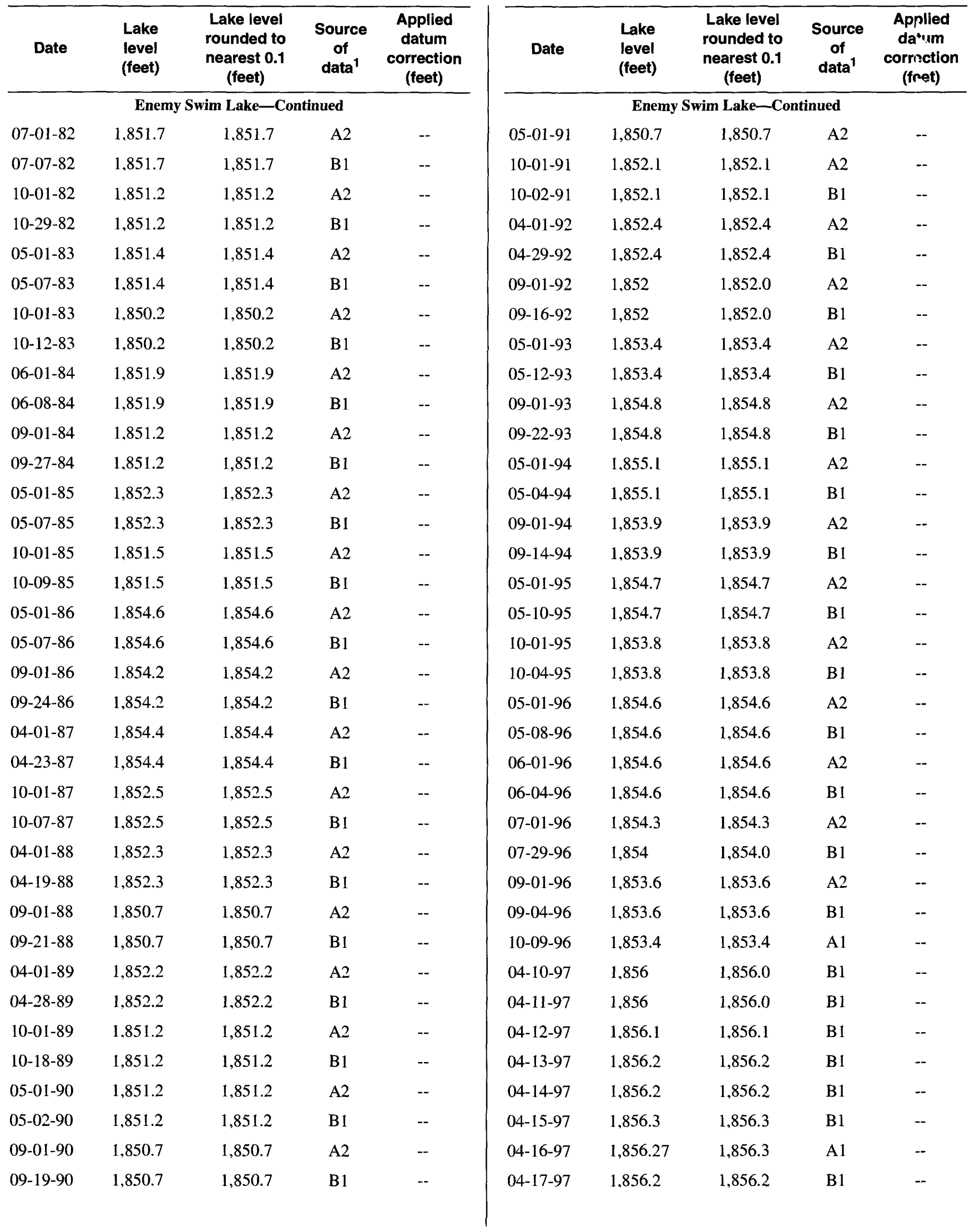


Table B1. Historic lake levels for the 10 major lakes of the Waubay Lakes Chain-Continued

[Lake levels in feet above sea level: --, none]

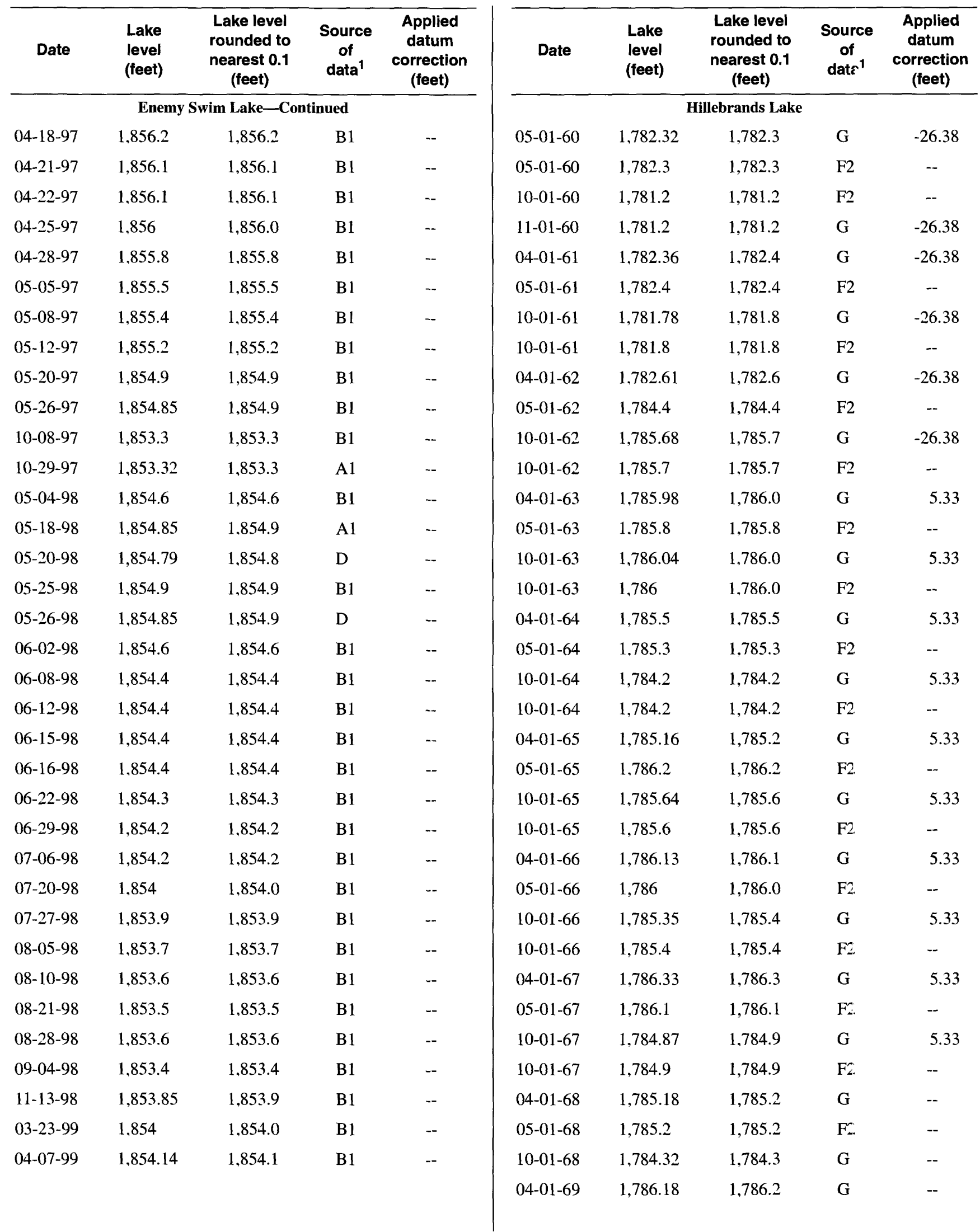


Table B1. Historic lake levels for the 10 major lakes of the Waubay Lakes Chain-Continued

[Lake levels in feet above sea level; --, none]

\begin{tabular}{|c|c|c|c|c|}
\hline Date & $\begin{array}{l}\text { Lake } \\
\text { level } \\
\text { (feet) }\end{array}$ & $\begin{array}{c}\text { Lake level } \\
\text { rounded to } \\
\text { nearest } 0.1 \\
\text { (feet) }\end{array}$ & $\begin{array}{c}\text { Source } \\
\text { of } \\
\text { data }^{1}\end{array}$ & $\begin{array}{c}\text { Applied } \\
\text { datum } \\
\text { correction } \\
\text { (feet) }\end{array}$ \\
\hline \multicolumn{5}{|c|}{ Hillebrands Lake_-Continued } \\
\hline $05-01-69$ & 1.786 .3 & $1,786.3$ & F2 & -- \\
\hline $10-01-69$ & $1,785.08$ & $1,785.1$ & G & -- \\
\hline $04-01-70$ & $1,785.69$ & $1,785.7$ & G & - \\
\hline $05-01-70$ & $1,785.7$ & $1,785.7$ & F2 & -- \\
\hline $10-01-70$ & $1,784.43$ & $1,784.4$ & G & -- \\
\hline $10-01-70$ & $1,784.3$ & $1,784.3$ & F2 & -- \\
\hline $04-01-71$ & $1,784.37$ & $1,784.4$ & G & -- \\
\hline $05-01-71$ & $1,784.3$ & $1,784.3$ & $\mathrm{~F} 2$ & -- \\
\hline $10-01-71$ & $1,784.07$ & $1,784.1$ & G & -- \\
\hline $05-01-72$ & 1,786 & $1,786.0$ & $\mathrm{~F} 2$ & -- \\
\hline $10-01-72$ & $1,785.2$ & $1,785.2$ & $\mathrm{~F} 2$ & -- \\
\hline $05-01-73$ & $1,785.9$ & $1,785.9$ & $\mathrm{~F} 2$ & -- \\
\hline $10-01-73$ & $1,784.5$ & $1,784.5$ & $\mathrm{~F} 2$ & -- \\
\hline $04-01-74$ & $1,785.37$ & $1,785.4$ & G & -- \\
\hline $05-01-74$ & $1,785.4$ & 1.785 .4 & $\mathrm{~F} 2$ & -- \\
\hline $10-01-74$ & $1,783.5$ & $1,783.5$ & G & -- \\
\hline $04-01-75$ & $1,784.33$ & $1,784.3$ & G & -- \\
\hline $05-01-75$ & $1,784.3$ & $1,784.3$ & $\mathrm{~F} 2$ & -- \\
\hline $10-01-75$ & $1,781.55$ & $1,781.6$ & G & -- \\
\hline $04-01-76$ & $1,783.74$ & $1,783.7$ & G & -- \\
\hline $05-01-76$ & $1,783.72$ & $1,783.7$ & $\mathrm{~F} 2$ & -0.09 \\
\hline $10-01-76$ & $1,781.06$ & $1,781.1$ & $\mathrm{G}$ & -- \\
\hline $10-01-76$ & $1,781.41$ & $1,781.4$ & F2 & -0.09 \\
\hline $04-01-77$ & $1,781.89$ & $1,781.9$ & G & -- \\
\hline $05-01-77$ & $1,781.9$ & 1.781 .9 & $\mathrm{~F} 2$ & -- \\
\hline $10-01-77$ & $1,781.21$ & $1,781.2$ & G & -- \\
\hline $04-01-78$ & $1,783.18$ & $1,783.2$ & G & -- \\
\hline $05-01-78$ & $1,783.2$ & $1,783.2$ & $\mathrm{~F} 2$ & - \\
\hline $10-01-78$ & $1,783.06$ & $1,783.1$ & G & -- \\
\hline $10-01-78$ & $1,783.2$ & $1,783.2$ & $\mathrm{~F} 2$ & -- \\
\hline 04-01-79 & $1,784.56$ & $1,784.6$ & $\mathrm{G}$ & -- \\
\hline 05-01-79 & $1,784.5$ & $1,784.5$ & $\mathrm{~F} 2$ & -- \\
\hline $10-01-79$ & $1,783.9$ & $1,783.9$ & $\mathrm{G}$ & -- \\
\hline $10-01-79$ & $1,784.3$ & $1,784.3$ & $\mathrm{~F} 2$ & -- \\
\hline $04-01-80$ & $1,785.48$ & $1,785.5$ & G & -- \\
\hline $05-01-80$ & $1,784.1$ & $1,784.1$ & $\mathrm{~F} 2$ & -- \\
\hline
\end{tabular}

\begin{tabular}{|c|c|c|c|c|}
\hline Date & $\begin{array}{l}\text { Lake } \\
\text { level } \\
\text { (feet) }\end{array}$ & $\begin{array}{l}\text { Lake level } \\
\text { rounded to } \\
\text { nearest } 0.1 \\
\text { (feet) }\end{array}$ & $\begin{array}{c}\text { Source } \\
\text { of } \\
\text { data }^{1}\end{array}$ & $\begin{array}{l}\text { Applied } \\
\text { dat"im } \\
\text { correction } \\
\text { (fent) }\end{array}$ \\
\hline \multicolumn{5}{|c|}{ Hillebrands Lake-Continued } \\
\hline $10-01-80$ & $1,783.3$ & $1,783.3$ & G & -- \\
\hline $10-01-80$ & $1,783.4$ & $1,783.4$ & F2 & -- \\
\hline $04-01-81$ & $1,783.15$ & $1,783.2$ & G & - \\
\hline $05-01-81$ & $1,783.2$ & $1,783.2$ & $\mathrm{~F} 2$ & -- \\
\hline $10-01-81$ & $1,782.01$ & $1,782.0$ & G & - \\
\hline 04-01-82 & 1.782 .77 & $1,782.8$ & G & - \\
\hline $05-01-82$ & $1,782.8$ & $1,782.8$ & $\mathrm{~F} 2$ & - \\
\hline $10-01-82$ & 1,782 & $1,782.0$ & $\mathrm{~F} 2$ & - \\
\hline $11-01-82$ & $1,782.06$ & $1,782.1$ & G & - \\
\hline $04-01-83$ & $1,782.37$ & $1,782.4$ & G & - \\
\hline $10-01-83$ & 1.781 .23 & $1,781.2$ & G & -- \\
\hline $10-11-83$ & $1,781.3$ & $1,781.3$ & B1 & - \\
\hline $05-01-84$ & $1,782.2$ & $1,782.2$ & G & -- \\
\hline $10-01-84$ & $1,781.6$ & $1,781.6$ & $\mathrm{G}$ & -- \\
\hline $10-09-84$ & $1,781.6$ & $1,781.6$ & B1 & -- \\
\hline $11-07-84$ & $1,781.9$ & $1,781.9$ & B1 & - \\
\hline $04-01-85$ & $1,782.48$ & $1,782.5$ & G & - \\
\hline $04-14-85$ & $1,782.5$ & $1,782.5$ & B1 & -- \\
\hline $10-01-85$ & $1,781.6$ & $1,781.6$ & G & - \\
\hline $11-01-85$ & $1,781.6$ & $1,781.6$ & B1 & -- \\
\hline $04-01-86$ & $1,783.47$ & $1,783.5$ & G & - \\
\hline $04-21-86$ & $1,783.5$ & $1,783.5$ & B1 & - \\
\hline $09-24-86$ & $1,785.1$ & $1,785.1$ & B1 & -- \\
\hline $10-01-86$ & $1,784.9$ & $1,784.9$ & G & -- \\
\hline $04-01-87$ & 1,786 & $1,786.0$ & G & - \\
\hline $04-23-87$ & 1,786 & $1,786.0$ & B1 & -- \\
\hline $10-01-87$ & $1,785.07$ & $1,785.1$ & $\mathrm{G}$ & - \\
\hline $10-07-87$ & $1,784.8$ & $1,784.8$ & B1 & - \\
\hline 04-01-88 & $1,785.04$ & $1,785.0$ & $\mathrm{G}$ & -- \\
\hline $04-20-88$ & 1,785 & $1,785.0$ & $\mathrm{~B} 1$ & -- \\
\hline $09-21-88$ & 1,784 & $1,784.0$ & B1 & -- \\
\hline $11-01-88$ & $1,783.78$ & $1,783.8$ & G & - \\
\hline $04-28-89$ & $1,785.2$ & $1,785.2$ & B1 & -- \\
\hline 05-01-89 & $1,784.63$ & $1,784.6$ & $\mathrm{G}$ & - \\
\hline $10-18-89$ & $1,784.3$ & $1,784.3$ & B1 & - \\
\hline $11-01-89$ & $1,783.73$ & $1,783.7$ & G & - \\
\hline
\end{tabular}


Table B1. Historic lake levels for the 10 major lakes of the Waubay Lakes Chain-Continued

[Lake levels in feet above sea level; --, none]

\begin{tabular}{|c|c|c|c|c|}
\hline Date & $\begin{array}{l}\text { Lake } \\
\text { level } \\
\text { (feet) }\end{array}$ & $\begin{array}{l}\text { Lake level } \\
\text { rounded to } \\
\text { nearest } 0.1 \\
\text { (feet) }\end{array}$ & $\begin{array}{c}\text { Source } \\
\text { of } \\
\text { data }^{1}\end{array}$ & $\begin{array}{l}\text { Applied } \\
\text { datum } \\
\text { correction } \\
\text { (feet) }\end{array}$ \\
\hline \multicolumn{5}{|c|}{ Hillebrands Lake-Continued } \\
\hline 05-02-90 & $1,784.5$ & $1,784.5$ & B1 & -- \\
\hline $06-01-90$ & $1,783.89$ & $1,783.9$ & $\mathrm{G}$ & -- \\
\hline $09-21-90$ & $1,784.1$ & $1,784.1$ & B1 & -- \\
\hline $11-01-90$ & $1,783.4$ & $1,783.4$ & G & -- \\
\hline $04-01-91$ & $1,783.43$ & $1,783.4$ & G & -- \\
\hline $05-01-91$ & $1,784.4$ & $1,784.4$ & B1 & -- \\
\hline $10-01-91$ & $1,784.46$ & $1,784.5$ & G & -- \\
\hline $10-02-91$ & 1,785 & $1,785.0$ & $\mathrm{~B} 1$ & -- \\
\hline 04-01-92 & $1,784.33$ & $1,784.3$ & G & - \\
\hline $04-29-92$ & $1,785.1$ & $1,785.1$ & B1 & -- \\
\hline $09-16-92$ & $1,784.9$ & $1,784.9$ & $\mathrm{~B} 1$ & -- \\
\hline $10-01-92$ & 1.783 .47 & $1,783.5$ & G & - \\
\hline 04-01-93 & $1,784.35$ & $1,784.4$ & G & -- \\
\hline $05-12-93$ & 1,785 & $1,785.0$ & B1 & -- \\
\hline $09-22-93$ & $1,786.8$ & $1,786.8$ & B1 & -- \\
\hline $05-01-94$ & $1,788.5$ & $1,788.5$ & G & -- \\
\hline 05-04-94 & $1,788.4$ & $1,788.4$ & B1 & -- \\
\hline 09-14-94 & $1,788.4$ & $1,788.4$ & B1 & -- \\
\hline $10-01-94$ & $1,788.41$ & 1.788 .4 & G & -- \\
\hline $05-01-95$ & $1,792.86$ & $1,792.9$ & G & -- \\
\hline $05-11-95$ & $1,792.9$ & $1,792.9$ & B1 & -- \\
\hline $10-01-95$ & $1,794.08$ & $1,794.1$ & G & -- \\
\hline $10-11-95$ & $1,794.1$ & $1,794.1$ & B1 & -- \\
\hline $04-01-96$ & $1,795.87$ & $1,795.9$ & $\mathrm{G}$ & -- \\
\hline $05-08-96$ & $1,796.1$ & $1,796.1$ & B1 & -- \\
\hline $06-05-96$ & $1,797.2$ & 1.797 .2 & B1 & -- \\
\hline $07-01-96$ & $1,796.8$ & $1,796.8$ & B1 & -- \\
\hline $07-29-96$ & $1,796.6$ & $1,796.6$ & B1 & -- \\
\hline 09-04-96 & $1,796.3$ & $1,796.3$ & B1 & -- \\
\hline $10-01-96$ & $1,796.86$ & $1,796.9$ & G & -- \\
\hline $10-09-96$ & $1,796.2$ & $1,796.2$ & B1 & - \\
\hline 04-01-97 & $1,798.3$ & $1,798.3$ & G & -- \\
\hline $04-10-97$ & $1,797.5$ & $1,797.5$ & B1 & -- \\
\hline $05-20-97$ & $1,799.2$ & $1,799.2$ & B1 & -- \\
\hline $10-01-97$ & $1,800.08$ & $1,800.1$ & G & -- \\
\hline $10-08-97$ & $1,799.4$ & $1,799.4$ & B1 & -- \\
\hline
\end{tabular}

\begin{tabular}{|c|c|c|c|c|}
\hline Date & $\begin{array}{l}\text { Lake } \\
\text { level } \\
\text { (feet) }\end{array}$ & $\begin{array}{c}\text { Lake level } \\
\text { rounded to } \\
\text { nearest } 0.1 \\
\text { (feet) }\end{array}$ & $\begin{array}{c}\text { Source } \\
\text { of } \\
\text { data }^{1}\end{array}$ & $\begin{array}{l}\text { Applied } \\
\text { datum } \\
\text { correction } \\
\text { (feet) }\end{array}$ \\
\hline \multicolumn{5}{|c|}{ Hillebrands Lake-Continued } \\
\hline $11-14-97$ & $1,799.98$ & $1,800.0$ & D & -- \\
\hline 04-14-98 & $1,801.34$ & $1,801.3$ & $\mathrm{D}$ & -- \\
\hline 04-20-98 & $1,801.43$ & $1,801.4$ & $\mathrm{D}$ & -- \\
\hline $04-27-98$ & $1,801.9$ & $1,801.9$ & $\mathrm{D}$ & -- \\
\hline $04-28-98$ & $1,801.9$ & $1,801.9$ & $\mathrm{D}$ & -- \\
\hline 05-04-98 & $1,801.6$ & $1,801.6$ & B1 & -- \\
\hline $05-04-98$ & $1,801.95$ & $1,802.0$ & $\mathrm{D}$ & -- \\
\hline $05-05-98$ & $1,801.95$ & $1,802.0$ & $\mathrm{D}$ & -- \\
\hline $05-07-98$ & $1,801.94$ & $1,801.9$ & $\mathrm{D}$ & -- \\
\hline $05-11-98$ & $1,801.98$ & $1,802.0$ & $\mathrm{D}$ & -- \\
\hline $05-11-98$ & $1,802.02$ & $1,802.0$ & $\mathrm{D}$ & -- \\
\hline $05-12-98$ & $1,802.4$ & $1,802.4$ & $\mathrm{D}$ & -- \\
\hline $05-15-98$ & $1,802.48$ & $1,802.5$ & $\mathrm{D}$ & -- \\
\hline 05-18-98 & $1,802.59$ & $1,802.6$ & $\mathrm{D}$ & -- \\
\hline $05-20-98$ & $1,802.6$ & $1,802.6$ & D & -- \\
\hline $05-26-98$ & $1,802.68$ & $1,802.7$ & $\mathrm{D}$ & -- \\
\hline $11-13-98$ & $1,802.13$ & $1,802.1$ & B1 & -- \\
\hline 03-23-99 & $1,802.7$ & $1,802.7$ & B1 & -- \\
\hline 04-07-99 & $1,802.91$ & $1,802.9$ & B1 & -- \\
\hline \multicolumn{5}{|c|}{ Minnewasta Lake } \\
\hline 08-01-34 & $1,788.7$ & $1,788.7$ & $\mathrm{E}$ & 12.1 \\
\hline $05-01-35$ & $1,788.2$ & $1,788.2$ & G & 12.1 \\
\hline $05-31-35$ & $1,788.2$ & $1,788.2$ & $\mathrm{E}$ & -- \\
\hline $05-01-36$ & $1,788.2$ & $1,788.2$ & $\mathrm{E}$ & 12.1 \\
\hline $10-01-36$ & $1,785.2$ & $1,785.2$ & $E$ & 12.1 \\
\hline $11-01-36$ & $1,785.4$ & $1,785.4$ & G & 12.1 \\
\hline $11-21-36$ & $1,785.4$ & $1,785.4$ & $\mathrm{E}$ & -- \\
\hline $05-29-37$ & $1,787.3$ & $1,787.3$ & $\mathrm{E}$ & -- \\
\hline $10-01-37$ & $1,785.4$ & $1,785.4$ & G & 12.1 \\
\hline $10-09-37$ & $1,785.4$ & $1,785.4$ & $\mathrm{E}$ & -- \\
\hline $10-01-38$ & $1,785.6$ & $1,785.6$ & G & 12.1 \\
\hline $10-09-38$ & $1,785.6$ & $1,785.6$ & $\mathrm{E}$ & -- \\
\hline $05-29-39$ & $1,785.1$ & $1,785.1$ & $\mathrm{E}$ & -- \\
\hline $11-01-39$ & dry & dry & G & -- \\
\hline $11-18-39$ & dry & dry & $\mathrm{E}$ & -- \\
\hline $05-01-40$ & $1,784.7$ & $1,784.7$ & G & 12.1 \\
\hline
\end{tabular}


Table B1. Historic lake levels for the 10 major lakes of the Waubay Lakes Chain-Continued

[Lake levels in feet above sea level: --, none]

\begin{tabular}{|c|c|c|c|c|c|c|c|c|c|}
\hline Date & $\begin{array}{l}\text { Lake } \\
\text { level } \\
\text { (feet) }\end{array}$ & $\begin{array}{l}\text { Lake level } \\
\text { rounded to } \\
\text { nearest } 0.1 \\
\text { (feet) }\end{array}$ & $\begin{array}{c}\text { Source } \\
\text { of } \\
\text { data }^{1}\end{array}$ & $\begin{array}{l}\text { Applied } \\
\text { datum } \\
\text { correction } \\
\text { (feet) }\end{array}$ & Date & $\begin{array}{l}\text { Lake } \\
\text { level } \\
\text { (feet) }\end{array}$ & $\begin{array}{l}\text { Lake level } \\
\text { rounded to } \\
\text { nearest } 0.1 \\
\text { (feet) }\end{array}$ & $\begin{array}{c}\text { Source } \\
\text { of } \\
\text { data }^{1}\end{array}$ & $\begin{array}{l}\text { Applied } \\
\text { dafum } \\
\text { corrention } \\
\text { (fent) }\end{array}$ \\
\hline $05-16-40$ & $1,784.7$ & $1,784.7$ & $\mathrm{E}$ & -- & $02-26-52$ & $1,797.4$ & $1,797.4$ & $\mathrm{E}$ & 11.6 \\
\hline $06-01-41$ & $1,784.9$ & $1,784.9$ & $\mathrm{G}$ & 12.1 & $05-01-52$ & $1,798.6$ & $1,798.6$ & G & 11.6 \\
\hline $11-01-41$ & $1,784.4$ & $1,784.4$ & $\mathrm{G}$ & 12.1 & $11-01-53$ & $1,796.3$ & $1,796.3$ & G & 11.6 \\
\hline $11-18-41$ & $1,784.4$ & $1,784.4$ & $\mathrm{E}$ & -- & $04-01-54$ & $1,796.5$ & $1,796.5$ & G & 11.6 \\
\hline $05-01-42$ & 1.785 .7 & $1,785.7$ & G & 12.1 & $09-01-54$ & $1,796.8$ & $1,796.8$ & G & 11.6 \\
\hline $05-30-42$ & $1,785.7$ & $1,785.7$ & $\mathrm{E}$ & -- & $05-01-55$ & $1,796.4$ & $1,796.4$ & G & 11.6 \\
\hline $06-01-43$ & 1,796 & $1,796.0$ & $\mathrm{G}$ & 11.6 & $09-01-57$ & $1,794.5$ & $1,794.5$ & G & 11.6 \\
\hline $06-17-43$ & 1,796 & $1,796.0$ & $\mathrm{E}$ & 11.6 & $04-01-59$ & $1,792.8$ & $1,792.8$ & G & 11.6 \\
\hline $11-01-43$ & $1,796.6$ & $1,796.6$ & G & 11.6 & $04-01-60$ & $1,792.1$ & $1,792.1$ & G & 11.6 \\
\hline $11-28-43$ & $1,796.6$ & $1,796.6$ & $\mathrm{E}$ & 11.6 & $06-05-61$ & $1,790.4$ & $1,790.4$ & $\mathrm{E}$ & 11.6 \\
\hline $11-01-44$ & $1,796.2$ & $1,796.2$ & G & 11.6 & $12-05-61$ & $1,789.5$ & $1,789.5$ & $\mathrm{E}$ & 11.6 \\
\hline $11-20-44$ & $1,796.2$ & $1,796.2$ & $\mathrm{E}$ & 11.6 & $06-07-62$ & $1,790.5$ & $1,790.5$ & $\mathrm{E}$ & 11.6 \\
\hline $05-01-45$ & 1,797 & $1,797.0$ & G & 11.6 & $12-01-62$ & $1,797.29$ & $1,797.3$ & G & 11.6 \\
\hline $05-06-45$ & 1,797 & $1,797.0$ & $\mathrm{E}$ & 11.6 & $12-13-62$ & $1,797.3$ & $1,797.3$ & $\mathrm{E}$ & 11.6 \\
\hline $05-24-47$ & $1,799.2$ & $1,799.2$ & $\mathrm{E}$ & 11.6 & $05-14-64$ & 1,798 & $1,798.0$ & $\mathrm{E}$ & 11.6 \\
\hline $05-01-48$ & $1,797.6$ & $1,797.6$ & $\mathrm{G}$ & 11.6 & $10-01-64$ & $1,796.25$ & $1,796.3$ & G & 11.6 \\
\hline $05-12-48$ & $1,797.6$ & $1,797.6$ & $\mathrm{E}$ & 11.6 & $10-15-64$ & 1.796 .2 & $1,796.2$ & $\mathrm{E}$ & 11.6 \\
\hline $05-19-48$ & 1,799 & $1,799.0$ & $\mathrm{E}$ & 11.6 & $05-01-66$ & $1,797.52$ & $1,797.5$ & G & 11.6 \\
\hline $05-01-49$ & $1,795.8$ & $1,795.8$ & $\mathrm{G}$ & 11.6 & $11-01-66$ & $1,796.05$ & $1,796.1$ & G & 11.6 \\
\hline $11-01-49$ & $1,794.8$ & $1,794.8$ & G & 11.6 & $05-01-67$ & $1,796.52$ & $1,796.5$ & G & 11.6 \\
\hline $11-12-49$ & $1,794.8$ & $1,794.8$ & $\mathrm{E}$ & 11.6 & $05-01-68$ & $1,795.07$ & $1,795.1$ & G & 11.6 \\
\hline $05-01-50$ & $1,795.7$ & $1,795.7$ & $\mathrm{G}$ & 11.6 & $11-01-68$ & $1,794.11$ & $1,794.1$ & $\mathbf{G}$ & 11.6 \\
\hline $05-16-50$ & $1,795.7$ & $1,795.7$ & $\mathrm{E}$ & 11.6 & $05-01-69$ & $1,796.9$ & $1,796.9$ & $\mathbf{G}$ & 11.6 \\
\hline $01-01-51$ & $1,792.8$ & $1,792.8$ & G & 11.6 & 09-01-69 & $1,796.58$ & $1,796.6$ & $\mathbf{G}$ & 11.6 \\
\hline $01-09-51$ & 1.792 .8 & $1,792.8$ & $\mathrm{E}$ & 11.6 & $05-01-70$ & $1,797.02$ & $1,797.0$ & $\mathrm{G}$ & 11.6 \\
\hline $05-01-51$ & $1,797.1$ & $1,797.1$ & $\mathrm{G}$ & 11.6 & $12-01-70$ & $1,795.92$ & $1,795.9$ & $\mathrm{G}$ & 11.6 \\
\hline $05-07-51$ & $1,797.1$ & $1,797.1$ & $\mathrm{E}$ & 11.6 & $11-02-83$ & $1,792.2$ & $1,792.2$ & B1 & -- \\
\hline $02-01-52$ & $1,797.4$ & $1,797.4$ & G & 11.6 & $06-09-84$ & $1,792.8$ & $1,792.8$ & B1 & -- \\
\hline
\end{tabular}


Table B1. Historic lake levels for the 10 major lakes of the Waubay Lakes Chain-Continued

[Lake levels in feet above sea level; --, none]

\begin{tabular}{|c|c|c|c|c|}
\hline Date & $\begin{array}{l}\text { Lake } \\
\text { level } \\
\text { (feet) }\end{array}$ & $\begin{array}{l}\text { Lake level } \\
\text { rounded to } \\
\text { nearest } 0.1 \\
\text { (feet) }\end{array}$ & $\begin{array}{c}\text { Source } \\
\text { of } \\
\text { data }^{1}\end{array}$ & $\begin{array}{c}\text { Applied } \\
\text { datum } \\
\text { correction } \\
\text { (feet) }\end{array}$ \\
\hline
\end{tabular}

Minnewasta Lake-Continued

10-09-85 $\quad 1,793.9 \quad 1,793.9 \quad$ B1

05-06-86 $1,798.6 \quad 1,798.6 \quad$ B

09-24-86 $1,798.1 \quad 1,798.1 \quad$ B1

04-23-87 $1,798 \quad 1,798.0 \quad$ B

$10-07-87 \quad 1,796.1 \quad 1,796.1 \quad$ B

04-20-88 $1,795.7 \quad 1,795.7$

09-21-88 1,794.2 $1,794.2 \quad$ B

04-28-89 $1,794.6 \quad 1,794.6 \quad$ B1

$10-19-89 \quad 1,793.5 \quad 1,793.5$

05-02-90 1,793.3 $1,793.3$

09-21-90 1,792.4 $\quad 1,792.4 \quad$ B

05-01-91 $\quad 1.792 .3 \quad 1.792 .3 \quad$ B

$\begin{array}{lll}10-02-91 & 1,792.9 & 1,792.9\end{array}$

04-29-92 $1,795.1 \quad 1,795.1 \quad$ B1

09-16-92 $\quad 1,794.8 \quad 1.794 .8 \quad$ B

$\begin{array}{lll}05-12-93 & 1.797 & 1,797.0\end{array}$

09-22-93 $1,798.8 \quad 1,798.8 \quad B$

05-04-94 $\quad 1,799.2 \quad 1,799.2 \quad$ B1

09-14-94 $1,797.7 \quad 1,797.7$

05-10-95 $\quad 1,798.8 \quad 1,798.8 \quad$ B

$\begin{array}{lll}10-11-95 & 1,797.9 & 1,797.9 \quad \text { B }\end{array}$

05-08-96 $\quad 1,798.4 \quad 1,798.4$

06-05-96 $1,798.4 \quad 1,798.4$

07-01-96 1,798.2 $1,798.2 \quad$ B

$\begin{array}{llll}07-29-96 & 1,797.7 & 1,797.7\end{array}$

09-04-96 $\quad 1,797.3 \quad 1,797.3$

$10-09-96 \quad 1,797.1 \quad 1,797.1$

$\begin{array}{lll}05-20-97 & 1,799.7 & 1,799.7\end{array}$

$\begin{array}{llll}10-08-97 & 1,799.5 & 1,799.5\end{array}$

$11-13-98 \quad 1,802.13 \quad 1,802.1$

03-23-99 1,802.7 $1,802.7$

04-07-99 $\quad 1,802.91 \quad 1,802.9 \quad$ B1

Pickerel Lake

$\begin{array}{llll}06-15-28 & 1,848.2 & 1,848.2 & \text { F } \\ 06-15-32 & 1,843.4 & 1,843.4 & \text { F } \\ 06-15-33 & 1,841.9 & 1,841.9 & \text { F }\end{array}$

F3 --

\begin{tabular}{|c|c|c|c|c|}
\hline Date & $\begin{array}{l}\text { Lake } \\
\text { level } \\
\text { (feet) }\end{array}$ & $\begin{array}{c}\text { Lake level } \\
\text { rounded to } \\
\text { nearest } 0.1 \\
\text { (feet) }\end{array}$ & $\begin{array}{c}\text { Source } \\
\text { of } \\
\text { data }^{1}\end{array}$ & $\begin{array}{l}\text { Applied } \\
\text { datum } \\
\text { correction } \\
\text { (feet) }\end{array}$ \\
\hline
\end{tabular}

Pickerel Lake-Continued

06-01-34 1,841.2 1,841.2 F2

$\begin{array}{llll}08-01-34 & 1,840.5 & 1,840.5 & \text { F2 }\end{array}$

08-10-34 $1,840.55 \quad 1,840.6 \quad \mathrm{E}$

08-18-34 $1,840.5 \quad 1,840.5 \quad \mathrm{E}$

11.9

$\begin{array}{llll}05-01-35 & 1,841.1 & 1,841.1 & \text { F2 }\end{array}$

10-01-35 $1,840.3 \quad 1,840.3 \quad$ F2

$\begin{array}{llll}10-19-35 & 1,840.3 & 1,840.3 & \mathrm{E}\end{array}$

04-01-36 $1,841 \quad 1,841.0 \quad$ F2

04-29-36 1,841

05-01-36

$1,840.5$

$1,841.0$

$1,840.5$

$1,838.2$

$1,838.2$

11-01-36

$1,838.2$

$1,838.2$

11-21-36

$1,838.2$

$1,838.2$

05-01-37

1,844

05-29-37

$1,843.9$

$1,844.0$

10-01-37

$1,843.4$

$1,843.9$

$1,843.4$

10-09-37

$1,843.4$

$1,843.4$

$1,844.9$

$1,844.9$

$1,843.8$

$1,843.8$

$1,845.4$

$1,845.4$

$1,843.8$

$1,843.8$

$1,844.9$

$1,844.9$

$1,843.8$

$1,843.8$

$1,845.5$

$1,845.5$

11-01-41 $1,844.7 \quad 1,844.7 \quad F_{\text {s }}$

$1,844.7$

05-01-42 $\quad 1,846 \quad 1,846.0 \quad F_{2}^{2}$

$1,845.1$

$11-03-42 \quad 1,845.1 \quad 1,845.1$

\section{2}

E

E

11.9

$--$

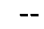

11.9

--

11.9

1.9

11.9

11.9

--

11.9

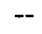

11.9

11.9

1.9

11.9

11.9

$--$

11.9

--

11.9

--

11.9

$-$

11.9

F。 --


Table B1. Historic lake levels for the 10 major lakes of the Waubay Lakes Chain-Continued

[Lake levels in feet above sea level; --, none]

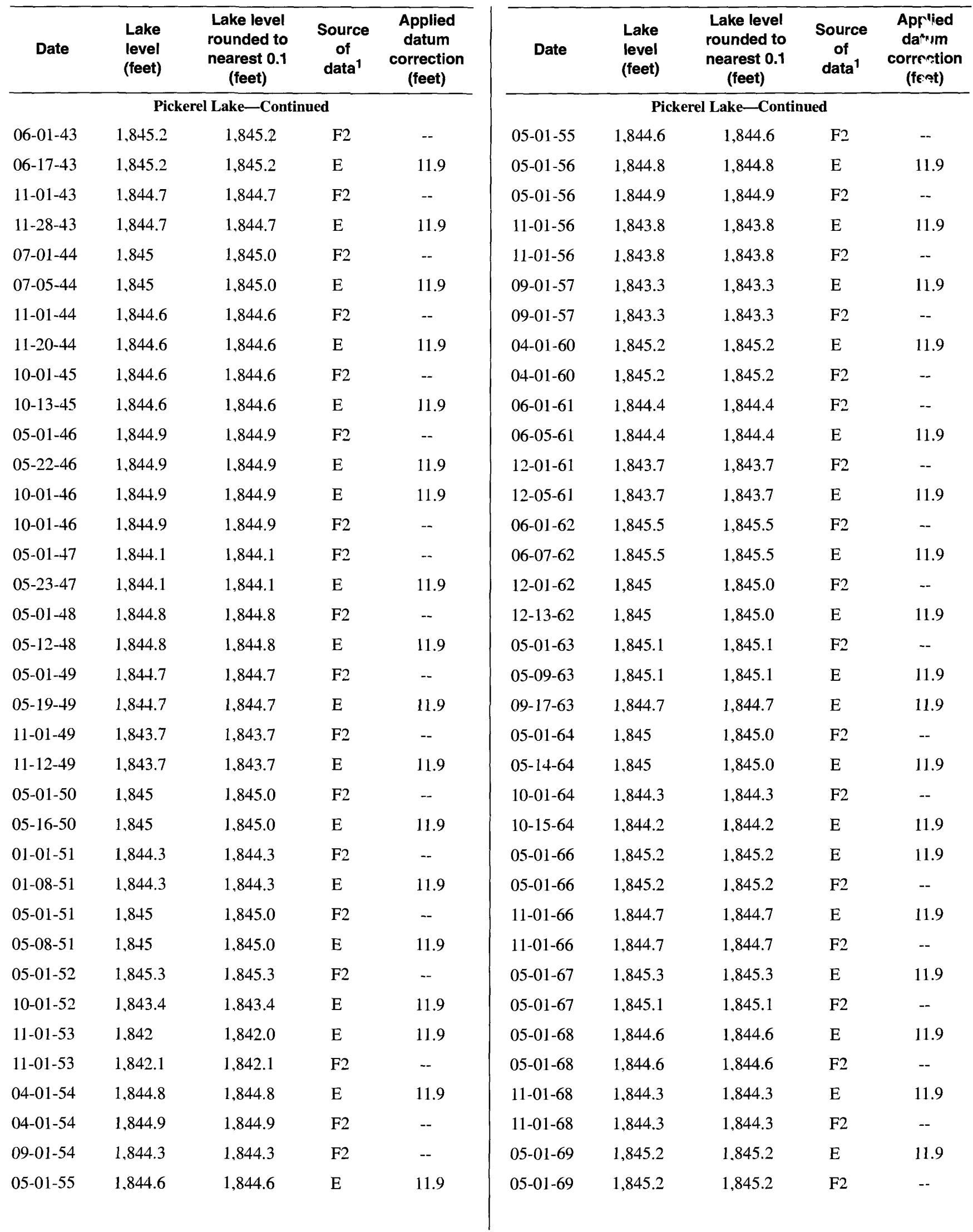


Table B1. Historic lake levels for the 10 major lakes of the Waubay Lakes Chain-Continued

[Lake levels in feet above sea level; --, none]

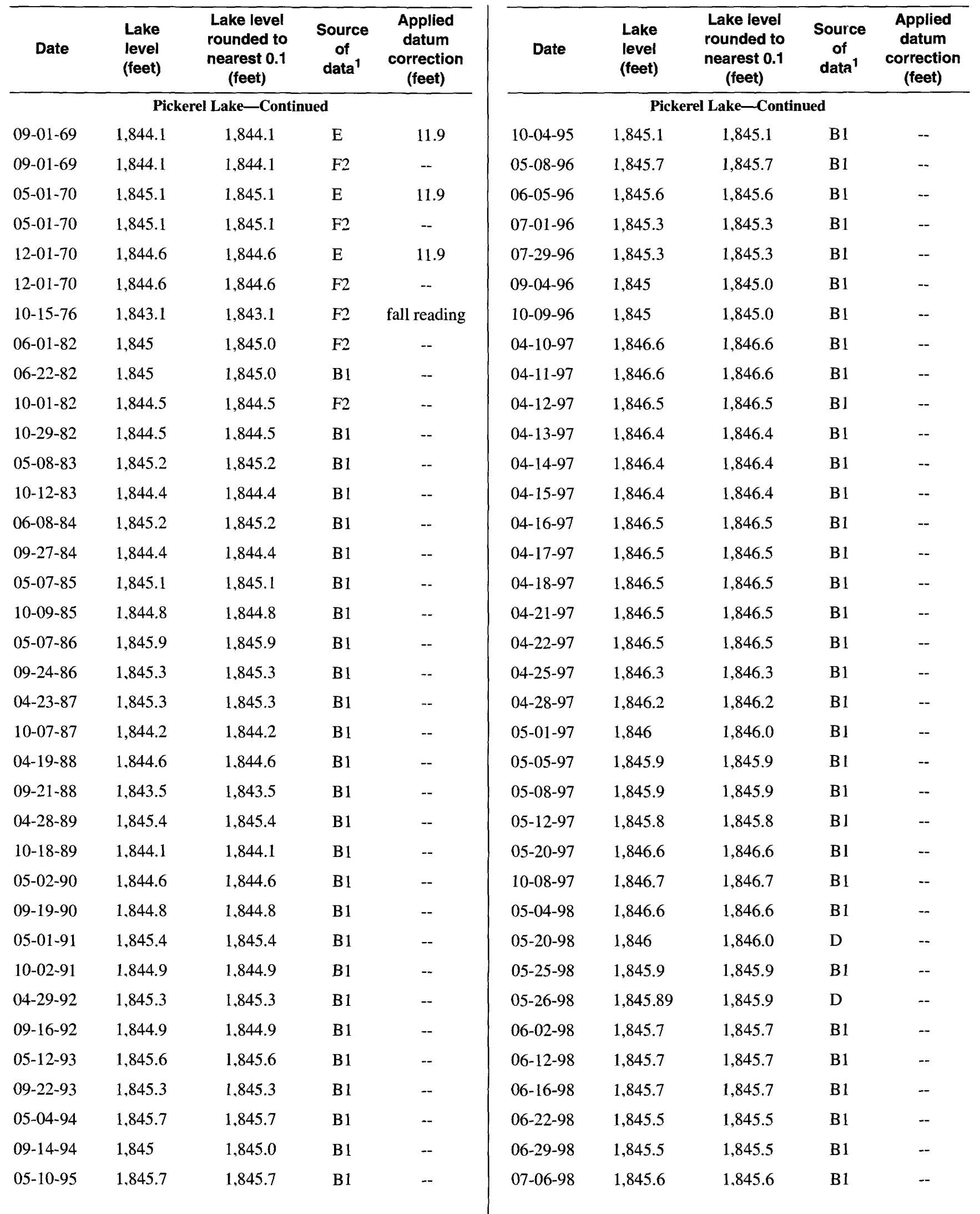


Table B1. Historic lake levels for the 10 major lakes of the Waubay Lakes Chain-Continued

[Lake levels in feet above sea level; --, none]

\begin{tabular}{ccccc}
\hline \multirow{3}{*}{ Date } & Lake & Lake level & Source \\
level & $\begin{array}{c}\text { Applied } \\
\text { datum } \\
\text { (feet) }\end{array}$ & $\begin{array}{c}\text { nearest } 0.1 \\
\text { (feet) }\end{array}$ & $\begin{array}{c}\text { of } \\
\text { data }^{1}\end{array}$ & $\begin{array}{c}\text { correction } \\
\text { (feet) }\end{array}$ \\
\hline
\end{tabular}

\begin{tabular}{cccc}
\multicolumn{3}{c}{ Pickerel Lake-Continued } \\
$07-20-98$ & $1,845.3$ & $1,845.3$ & B1
\end{tabular}

\begin{tabular}{|c|c|c|c|c|}
\hline Date & $\begin{array}{l}\text { Lake } \\
\text { level } \\
\text { (feet) }\end{array}$ & $\begin{array}{l}\text { Lake level } \\
\text { rounded to } \\
\text { nearest } 0.1 \\
\text { (feet) }\end{array}$ & $\begin{array}{c}\text { Source } \\
\text { of } \\
\text { data }^{1}\end{array}$ & $\begin{array}{l}\text { Applied } \\
\text { datum } \\
\text { correction } \\
\text { (fent) }\end{array}$ \\
\hline
\end{tabular}

$\begin{array}{lllll}07-27-98 & 1,845.2 & 1,845.2 & \text { B1 } & - \\ 08-05-98 & 1,845 & 1,845.0 & \text { B1 } & - \\ 08-10-98 & 1,845.1 & 1,845.1 & \text { B1 } & - \\ 08-21-98 & 1,845.1 & 1,845.1 & \text { B1 } & -\end{array}$

\begin{tabular}{lllll}
\hline \multicolumn{5}{c}{ Rush Lake-Continued } \\
$06-05-96$ & $1,800.1$ & $1,800.1$ & F1 & -- \\
$07-01-96$ & $1,799.8$ & $1,799.8$ & F1 & -- \\
$07-29-96$ & $1,799.3$ & $1,799.3$ & F1 & -- \\
$09-04-96$ & $1,798.7$ & $1,798.7$ & F1 & -- \\
$10-09-96$ & $1,798.5$ & $1,798.5$ & F1 & --
\end{tabular}

$\begin{array}{lllll}08-28-98 & 1,845.2 & 1,845.2 & \text { B1 } & - \\ 09-04-98 & 1,845 & 1,845.0 & \text { B1 } & -\end{array}$

$\begin{array}{rlrll}04-07-99 & 1,845.73 & 1,845.7 & \text { B1 } & -- \\ & & \text { Rush Lake } & & \end{array}$

$\begin{array}{lllll}06-15-70 & 1,799 & 1,799.0 & \mathrm{U} & -- \\ 11-02-83 & 1,797.6 & 1,797.6 & \text { F1 } & -- \\ 06-08-84 & 1,798.8 & 1,798.8 & \text { F1 } & --\end{array}$

04-11-97 $1,801.2 \quad 1,801.2 \quad$ F1

04-12-97 1,801.2 $1,801.2 \quad F 1$

04-13-97 1,801.2 $\quad 1,801.2 \quad$ F1

04-14-97 1,801.2 $\quad 1,801.2 \quad$ F1

04-15-97 1,801.2 $\quad 1,801.2 \quad$ F1

04-16-97 1,801.2 $1,801.2 \quad$ F1

04-17-97 1,801.2 $1,801.2 \quad$ F1

04-18-97 $1,801.3 \quad 1,801.3 \quad$ F1

$\begin{array}{lllll}08-22-84 & 1,798.3 & 1,798.3 & \text { F1 } & -- \\ 05-07-85 & 1,798.8 & 1,798.8 & \text { F1 } & -- \\ 10-09-85 & 1,798.8 & 1,798.8 & \text { F1 } & \end{array}$

$\begin{array}{lllll}10-09-85 & 1,798.8 & 1,798.8 & \text { F1 } & -- \\ 05-06-86 & 1,800.1 & 1,800.1 & \text { F1 } & -- \\ 09-24-86 & 1,799.7 & 1,799.7 & \text { F1 } & --\end{array}$

04-19-97 1,801.3 $1,801.3 \quad$ F1

04-20-97 $1,801.4 \quad 1,801.4 \quad$ F1

04-21-97 1,801.5 $\quad 1,801.5 \quad$ F1

04-22-97 $\quad 1,801.5 \quad 1,801.5 \quad$ F1

04-25-97 $1,801.6 \quad 1,801.6 \quad$ F1

$\begin{array}{lllll}04-22-87 & 1.799 .7 & 1,799.7 & \text { F1 } & -- \\ 10-06-87 & 1.797 .7 & 1.797 .7 & \text { F1 } & --\end{array}$

$\begin{array}{lllll}04-19-88 & 1,797.8 & 1,797.8 & F 1 & --\end{array}$

$\begin{array}{llll}04-28-97 & 1,801.8 & 1,801.8 & \text { F1 }\end{array}$

$\begin{array}{lllll}09-21-88 & 1,796.5 & 1,796.5 & \text { Fl } & - \\ 04-26-89 & 1,798.5 & 1,798.5 & \text { Fl } & -\end{array}$

\begin{tabular}{lllll|}
$10-18-89$ & $1,797.6$ & $1,797.6$ & Fl & - \\
$05-02-90$ & $1,797.9$ & $1,797.9$ & Fl & -
\end{tabular}

$\begin{array}{lllll}05-02-90 & 1,797.9 & 1,797.9 & \text { F1 } & -- \\ 09-19-90 & 1,796.5 & 1,796.5 & \text { F1 } & -- \\ 05-01-91 & 1,797.5 & 1,797.5 & \text { F1 } & -- \\ 10-03-91 & 1,798.8 & 1,798.8 & \text { F1 } & -- \\ 04-29-92 & 1,799 & 1,799.0 & \text { F1 } & -- \\ 09-16-92 & 1,798.4 & 1,798.4 & \text { F1 } & -- \\ 05-12-93 & 1,799.4 & 1,799.4 & \text { F1 } & -- \\ 09-23-93 & 1,800.3 & 1,800.3 & \text { F1 } & -- \\ 05-05-94 & 1,800.6 & 1,800.6 & \text { F1 } & -- \\ 09-14-94 & 1,799.2 & 1,799.2 & \text { F1 } & -- \\ 05-10-95 & 1,800.4 & 1,800.4 & \text { F1 } & -- \\ 10-10-95 & 1,799.4 & 1,799.4 & \text { F1 } & -- \\ 05-08-96 & 1,800 & 1,800.0 & \text { F1 } & -\end{array}$

$\begin{array}{lllll}05-05-97 & 1,801.6 & 1,801.6 & \text { F1 } & -- \\ 05-09-97 & 1,801.6 & 1,801.6 & \text { F1 } & -- \\ 05-13-97 & 1,801.6 & 1,801.6 & \text { F1 } & -- \\ 05-16-97 & 1,800.45 & 1,800.5 & \text { C } & -- \\ 05-20-97 & 1,800.4 & 1,800.4 & \text { B1 } & -- \\ 10-07-97 & 1,799.8 & 1,799.8 & \text { B1 } & -- \\ 05-04-98 & 1,801.8 & 1,801.8 & \text { B1 } & -- \\ 05-20-98 & 1,802.9 & 1,802.9 & \text { D } & -- \\ 05-25-98 & 1,802.9 & 1,802.9 & \text { B1 } & -- \\ 05-26-98 & 1,802.95 & 1,803.0 & \text { D } & -- \\ 06-02-98 & 1,802.9 & 1,802.9 & \text { B1 } & -- \\ 06-08-98 & 1,802.8 & 1,802.8 & \text { B1 } & - \\ 06-12-98 & 1,803 & 1,803.0 & \text { B1 } & - \\ 06-16-98 & 1,803.1 & 1,803.1 & \text { B1 } & - \\ 06-22-98 & 1,803.1 & 1,803.1 & \text { B1 } & - \\ 07-06-98 & 1,803.2 & 1,803.2 & \text { B1 } & -\end{array}$


Table B1. Historic lake levels for the 10 major lakes of the Waubay Lakes Chain-Continued

[Lake levels in feet above sea level: --, none]

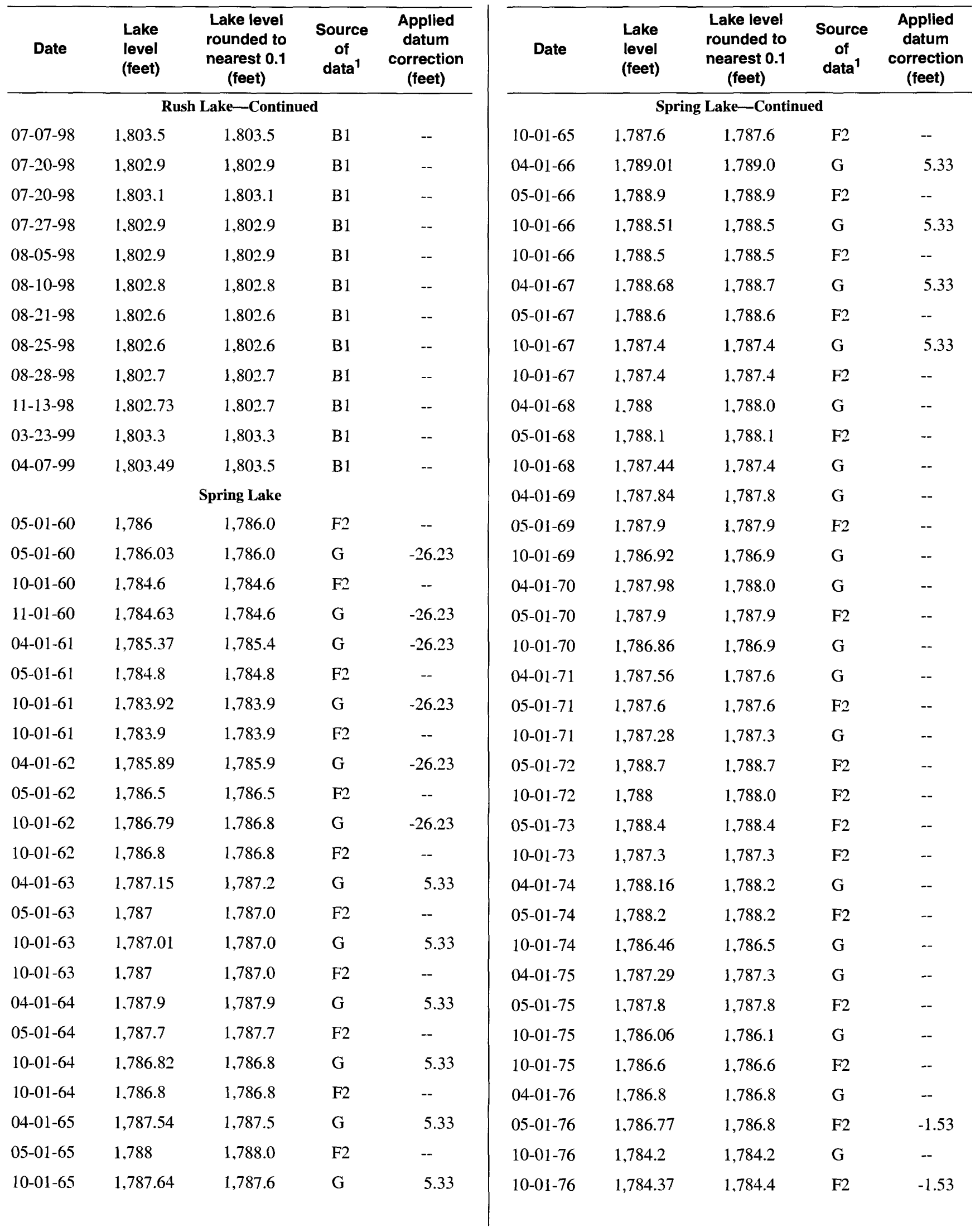


Table B1. Historic lake levels for the 10 major lakes of the Waubay Lakes Chain-Continued

[Lake levels in feet above sea level; --, none]

\begin{tabular}{|c|c|c|c|c|}
\hline Date & $\begin{array}{l}\text { Lake } \\
\text { level } \\
\text { (feet) }\end{array}$ & $\begin{array}{c}\text { Lake level } \\
\text { rounded to } \\
\text { nearest } 0.1 \\
\text { (feet) }\end{array}$ & $\begin{array}{c}\text { Source } \\
\text { of } \\
\text { data }^{1}\end{array}$ & $\begin{array}{c}\text { Applied } \\
\text { datum } \\
\text { correction } \\
\text { (feet) }\end{array}$ \\
\hline \multicolumn{5}{|c|}{ Spring Lake-Continued } \\
\hline 04-01-77 & $1,785.03$ & $1,785.0$ & $\mathrm{G}$ & -- \\
\hline $05-01-77$ & $1,784.6$ & $1,784.6$ & $\mathrm{~F} 2$ & -- \\
\hline $10-01-77$ & $1,783.89$ & $1,783.9$ & G & -- \\
\hline $04-01-78$ & $1,785.98$ & 1.786 .0 & $\mathrm{G}$ & -- \\
\hline $05-01-78$ & 1,786 & $1,786.0$ & $\mathrm{~F}^{2}$ & -- \\
\hline $10-01-78$ & $1,786.52$ & $1,786.5$ & $\mathrm{G}$ & -- \\
\hline $10-01-78$ & $1,786.6$ & $1,786.6$ & $\mathrm{~F} 2$ & -- \\
\hline 04-01-79 & $1,786.73$ & $1,786.7$ & $\mathrm{G}$ & -- \\
\hline $05-01-79$ & $1,786.7$ & $1,786.7$ & $\mathrm{~F} 2$ & -- \\
\hline $10-01-79$ & $1,786.17$ & $1,786.2$ & $\mathrm{G}$ & -- \\
\hline $10-01-79$ & $1,786.5$ & $1,786.5$ & $\mathrm{~F} 2$ & -- \\
\hline $04-01-80$ & $1,786.82$ & $1,786.8$ & $\mathrm{G}$ & -- \\
\hline $05-01-80$ & $1,786.5$ & $1,786.5$ & $\mathrm{~F} 2$ & -- \\
\hline $10-01-80$ & $1,785.92$ & $1,785.9$ & $\mathrm{G}$ & -- \\
\hline $04-01-81$ & $1,785.9$ & 1.785 .9 & $\mathrm{G}$ & -- \\
\hline $05-01-81$ & $1,785.9$ & $1,785.9$ & F2 & -- \\
\hline $10-01-81$ & $1,784.94$ & $1,784.9$ & G & -- \\
\hline 04-01-82 & $1,786.28$ & $1,786.3$ & $\mathrm{G}$ & -- \\
\hline $05-01-82$ & $1,786.3$ & $1,786.3$ & $\mathrm{~F} 2$ & -- \\
\hline $10-01-82$ & $1,785.7$ & $1,785.7$ & $\mathrm{~F} 2$ & -- \\
\hline $11-01-82$ & $1,785.84$ & $1,785.8$ & G & -- \\
\hline $04-01-83$ & $1,785.8$ & $1,785.8$ & $\mathrm{~F} 2$ & -- \\
\hline $04-01-83$ & $1,785.95$ & $1,786.0$ & $\mathrm{G}$ & -- \\
\hline $10-01-83$ & $1,785.81$ & $1,785.8$ & G & -- \\
\hline $10-11-83$ & 1,785 & 1.785 .0 & B1 & -- \\
\hline $05-01-84$ & $1,786.08$ & $1,786.1$ & G & -- \\
\hline $10-01-84$ & $1,785.4$ & $1,785.4$ & $\mathrm{G}$ & -- \\
\hline $10-09-84$ & $1,785.4$ & $1,785.4$ & B1 & -- \\
\hline $11-07-84$ & $1,785.6$ & $1,785.6$ & B1 & -- \\
\hline $04-01-85$ & $1,786.13$ & $1,786.1$ & G & -- \\
\hline $04-17-85$ & $1,786.1$ & $1,786.1$ & B1 & -- \\
\hline $10-01-85$ & $1,785.4$ & $1,785.4$ & $\mathrm{G}$ & -- \\
\hline $11-01-85$ & 1.785 .4 & 1.785 .4 & B1 & -- \\
\hline 04-01-86 & $1,786.89$ & $1,786.9$ & $\mathrm{G}$ & -- \\
\hline $04-21-86$ & $1,786.9$ & $1,786.9$ & B1 & -- \\
\hline $09-24-86$ & $1,787.5$ & $1,787.5$ & B1 & -- \\
\hline
\end{tabular}

Date

$\begin{array}{cc}\text { Lake } & \text { Lake level } \\ \text { level } & \text { rounded to } \\ \text { (feet) } & \begin{array}{c}\text { nearest } 0.1 \\ \text { (feet) }\end{array}\end{array}$

\begin{tabular}{cc}
$\begin{array}{c}\text { Source } \\
\text { of } \\
\text { data }^{1}\end{array}$ & $\begin{array}{c}\text { Applied } \\
\text { datum } \\
\text { corrostion } \\
\text { (fe } 9 t)\end{array}$ \\
\hline
\end{tabular}

Spring Lake-Continued

$\begin{array}{lll}10-01-86 & 1,787.52 & 1,787.5 \quad G\end{array}$

$\begin{array}{llll}10-07-86 & 1,786.8 & 1,786.8 & B 1\end{array}$

04-01-87 $1,788.2 \quad 1,788.2 \quad$ G

04-23-87 $1,788.2 \quad 1,788.2 \quad$ B1

$\begin{array}{llll}10-01-87 & 1,786.56 & 1,786.6 & G\end{array}$

$\begin{array}{llll}10-07-87 & 1,786.8 & 1,786.8 & \text { B1 }\end{array}$

04-01-88 $1,787.06 \quad 1,787.1 \quad$ G

04-20-88 $1,787 \quad 1,787.0 \quad$ B 1

$\begin{array}{llll}09-21-88 & 1,785.9 & 1,785.9 & \text { B } 1\end{array}$

$\begin{array}{llll}11-01-88 & 1,785.71 & 1,785.7 & \text { G }\end{array}$

04-28-89 $1,787.1 \quad 1,787.1 \quad \mathrm{~B}$

05-01-89 $1,786.98 \quad 1,787.0 \quad$ G

$\begin{array}{llll}10-18-89 & 1,786.2 & 1,786.2 & \text { B1 }\end{array}$

$\begin{array}{lll}11-01-89 & 1,786.08 & 1,786.1\end{array}$

$\begin{array}{llll}05-02-90 & 1.786 .6 & 1.786 .6 & B 1\end{array}$

06-01-90 $1,786.08 \quad 1,786.1 \quad$ G

09-20-90 $1,786.3 \quad 1,786.3 \quad$ B 1

$\begin{array}{llll}05-01-91 & 1,786.8 & 1,786.8 & \text { B1 }\end{array}$

$\begin{array}{llll}10-02-91 & 1,787.1 & 1,787.1 & B 1\end{array}$

$\begin{array}{llll}04-29-92 & 1,787.6 & 1,787.6 & \text { B1 }\end{array}$

09-16-92 $1,787.1 \quad 1,787.1 \quad$ B1

$\begin{array}{llll}05-12-93 & 1,787.8 & 1,787.8 & B 1\end{array}$

$\begin{array}{llll}09-22-93 & 1,788 & 1,788.0 & \text { B1 }\end{array}$

05-01-94 $1,790 \quad 1,790.0 \quad$ G

$\begin{array}{llll}05-04-94 & 1,789.7 & 1,789.7 & \text { B1 }\end{array}$

$\begin{array}{llll}09-14-94 & 1,788.9 & 1,788.9 & \text { B1 }\end{array}$

$\begin{array}{llll}05-01-95 & 1,790.44 & 1,790.4 & G\end{array}$

$\begin{array}{llll}05-11-95 & 1,791 & 1,791.0 & \text { B1 }\end{array}$

$\begin{array}{llll}10-01-95 & 1,790.58 & 1,790.6 \quad G\end{array}$

$\begin{array}{llll}10-11-95 & 1,790.6 & 1,790.6 & \text { B1 }\end{array}$

05-01-96 $1,791.98 \quad 1,792.0 \quad$ G

$\begin{array}{llll}05-08-96 & 1,791.8 & 1,791.8 & \text { B } 1\end{array}$

$\begin{array}{llll}06-05-96 & 1,792.5 & 1,792.5 & B 1\end{array}$

$\begin{array}{llll}07-01-96 & 1,792.1 & 1,792.1 & \text { B1 }\end{array}$

$\begin{array}{llll}07-29-96 & 1,792 & 1,792.0 & \text { B1 }\end{array}$

$\begin{array}{llll}09-04-96 & 1.791 .8 & 1,791.8 & \text { B1 }\end{array}$ 
Table B1. Historic lake levels for the 10 major lakes of the Waubay Lakes Chain-Continued

[Lake levels in feet above sea level; --, none]

\begin{tabular}{|c|c|c|c|c|c|c|c|c|c|}
\hline Date & $\begin{array}{l}\text { Lake } \\
\text { level } \\
\text { (feet) }\end{array}$ & $\begin{array}{l}\text { Lake level } \\
\text { rounded to } \\
\text { nearest } 0.1 \\
\text { (feet) }\end{array}$ & $\begin{array}{c}\text { Source } \\
\text { of } \\
\text { data }^{1}\end{array}$ & $\begin{array}{l}\text { Applied } \\
\text { datum } \\
\text { correction } \\
\text { (feet) }\end{array}$ & Date & $\begin{array}{l}\text { Lake } \\
\text { level } \\
\text { (feet) }\end{array}$ & $\begin{array}{c}\text { Lake level } \\
\text { rounded to } \\
\text { nearest } 0.1 \\
\text { (feet) }\end{array}$ & $\begin{array}{c}\text { Source } \\
\text { of } \\
\text { data }^{1}\end{array}$ & $\begin{array}{l}\text { Applied } \\
\text { datum } \\
\text { correction } \\
\text { (feet) }\end{array}$ \\
\hline \multicolumn{5}{|c|}{ Spring Lake-Continued } & \multicolumn{5}{|c|}{ Swan Pond-Continued } \\
\hline $10-01-96$ & $1,792.46$ & $1,792.5$ & G & -- & $05-01-66$ & 1.786 .8 & $1,786.8$ & $\mathrm{~F} 2$ & -- \\
\hline $10-09-96$ & $1,791.7$ & $1,791.7$ & B1 & -- & $10-01-66$ & $1,786.2$ & $1,786.2$ & $\mathrm{~F} 2$ & -- \\
\hline $04-10-97$ & 1.796 .4 & $1,796.4$ & B1 & -- & $10-01-67$ & $1,785.8$ & 1.785 .8 & $\mathrm{~F} 2$ & -- \\
\hline $05-29-97$ & 1.799 .2 & $1,799.2$ & B1 & - & $05-01-68$ & $1,785.8$ & 1.785 .8 & $\mathrm{~F} 2$ & -- \\
\hline $06-09-97$ & $1,799.6$ & $1,799.6$ & B1 & -- & $10-01-68$ & $1,785.3$ & $1,785.3$ & $\mathrm{~F} 2$ & -- \\
\hline $10-01-97$ & 1.800 .08 & $1,800.1$ & $\mathrm{G}$ & -- & $05-01-69$ & $1,786.6$ & $1,786.6$ & $\mathrm{~F} 2$ & - \\
\hline 04-14-98 & $1,801.34$ & $1,801.3$ & D & -- & $10-01-70$ & $1,783.7$ & $1,783.7$ & $\mathrm{~F} 2$ & -- \\
\hline $04-20-98$ & $1,801.43$ & $1,801.4$ & D & -- & $05-01-71$ & $1,784.8$ & $1,784.8$ & $\mathrm{~F} 2$ & -- \\
\hline $04-27-98$ & $1,801.9$ & $1,801.9$ & D & -- & $10-01-71$ & $1,784.5$ & $1,784.5$ & $\mathrm{~F} 2$ & -- \\
\hline 04-28-98 & $1,801.9$ & $1,801.9$ & D & -- & $05-01-72$ & $1,787.7$ & $1,787.7$ & $\mathrm{~F} 2$ & -- \\
\hline 05-04-98 & $1,801.6$ & $1,801.6$ & B1 & -- & $10-01-72$ & $1,787.9$ & $1,787.9$ & $\mathrm{~F} 2$ & -- \\
\hline 05-04-98 & $1,801.95$ & $1,802.0$ & D & -- & $05-01-73$ & $1,787.7$ & $1,787.7$ & $\mathrm{~F} 2$ & -- \\
\hline $05-05-98$ & $1,801.95$ & $1,802.0$ & D & -- & $10-01-73$ & $1,786.4$ & $1,786.4$ & $\mathrm{~F} 2$ & -- \\
\hline $05-07-98$ & $1,801.94$ & $1,801.9$ & D & -- & $05-01-74$ & $1,786.9$ & $1,786.9$ & $\mathrm{~F} 2$ & -- \\
\hline $05-20-98$ & $1,802.6$ & $1,802.6$ & D & -- & $05-01-77$ & $1,781.7$ & $1,781.7$ & $\mathrm{~F} 2$ & -- \\
\hline $05-26-98$ & $1,802.68$ & $1,802.7$ & D & -- & $10-01-77$ & $1,781.1$ & $1,781.1$ & $\mathrm{~F} 2$ & -- \\
\hline $11-13-98$ & $1,802.13$ & $1,802.1$ & D & -- & $05-01-78$ & $1,783.2$ & $1,783.2$ & $\mathrm{~F} 2$ & -- \\
\hline 03-23-99 & $1,802.7$ & $1,802.7$ & D & -- & $10-01-78$ & 1.782 .9 & $1,782.9$ & $\mathrm{~F} 2$ & -- \\
\hline 04-07-99 & $1,802.91$ & $1,802.9$ & D & -- & $05-01-79$ & $1,783.8$ & $1,783.8$ & $\mathrm{~F} 2$ & -- \\
\hline & & Swan Pond & & & $10-01-79$ & 1.783 .2 & $1,783.2$ & $\mathrm{~F} 2$ & - \\
\hline $05-01-62$ & $1,785.3$ & $1,785.3$ & $\mathrm{~F} 2$ & -- & $05-01-80$ & $1,783.5$ & $1,783.5$ & $\mathrm{~F} 2$ & -- \\
\hline $10-01-62$ & $1,785.5$ & $1,785.5$ & $\mathrm{~F} 2$ & -- & $10-01-80$ & 1.782 .5 & $1,782.5$ & $\mathrm{~F} 2$ & -- \\
\hline $05-01-63$ & $1,785.4$ & $1,785.4$ & $\mathrm{~F} 2$ & -- & $05-01-81$ & $1,784.9$ & $1,784.9$ & $\mathrm{~F} 2$ & - \\
\hline $10-01-63$ & $1,785.4$ & $1,785.4$ & $\mathrm{~F} 2$ & - & $10-01-81$ & $1,783.5$ & $1,783.5$ & $\mathrm{~F} 2$ & - \\
\hline $05-01-64$ & $1,785.8$ & $1,785.8$ & $\mathrm{~F} 2$ & -- & $05-01-82$ & 1,784 & $1,784.0$ & $\mathrm{~F} 2$ & -- \\
\hline $10-01-64$ & $1,784.8$ & $1,784.8$ & $\mathrm{~F} 2$ & - & $10-01-82$ & $1,783.3$ & $1,783.3$ & $\mathrm{~F} 2$ & -- \\
\hline $05-01-65$ & 1,786 & $1,786.0$ & $\mathrm{~F} 2$ & - & $04-01-83$ & $1,783.8$ & $1,783.8$ & $\mathrm{~F} 2$ & -- \\
\hline $10-01-65$ & $1,785.7$ & $1,785.7$ & $\mathrm{~F} 2$ & -- & $09-24-86$ & $1,786.4$ & $1,786.4$ & B1 & -- \\
\hline
\end{tabular}


Table B1. Historic lake levels for the 10 major lakes of the Waubay Lakes Chain-Continued

[Lake levels in feet above sea level; --, none]

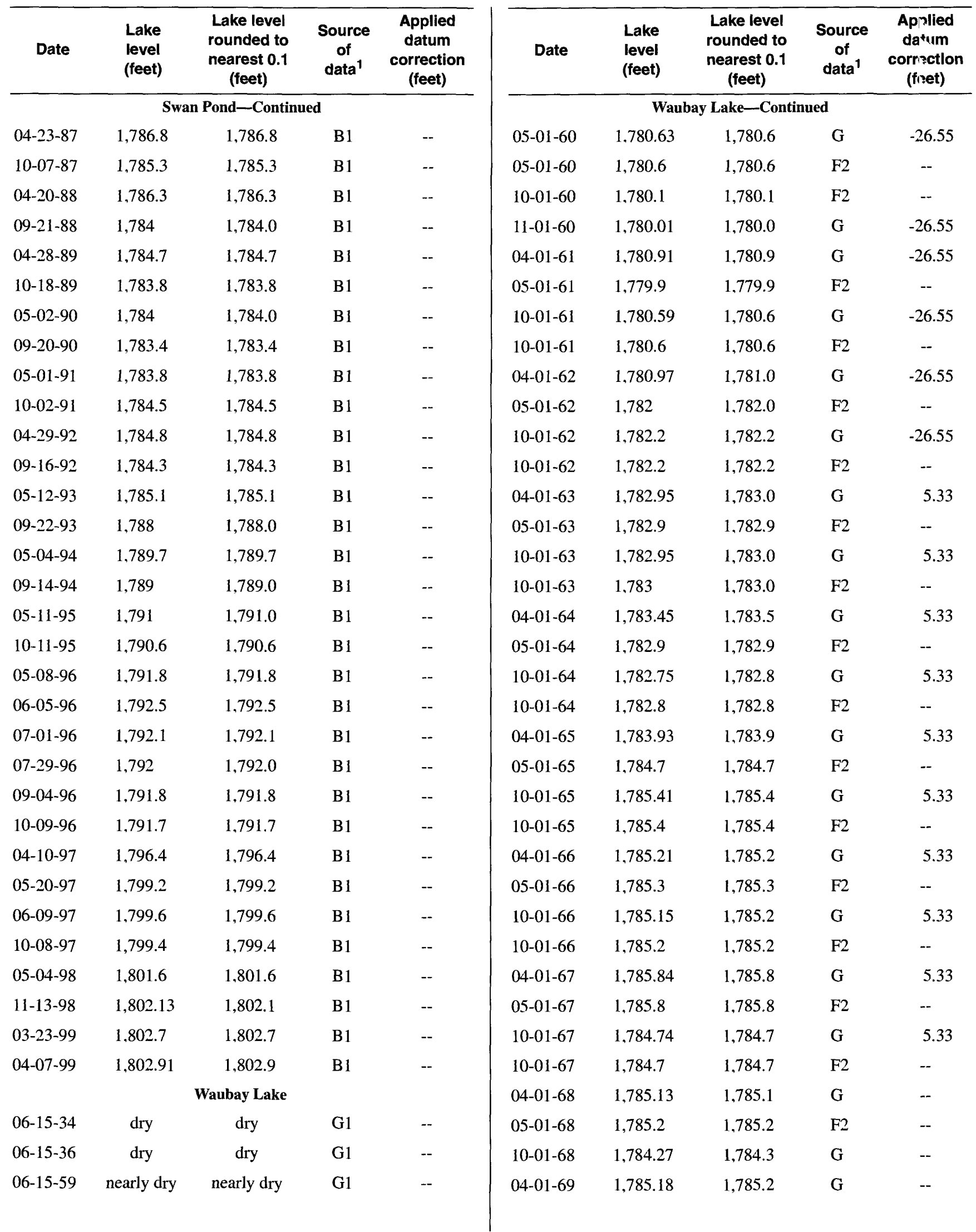


Table B1. Historic lake levels for the 10 major lakes of the Waubay Lakes Chain-Continued

[Lake levels in feet above sea level; --, none]

\begin{tabular}{|c|c|c|c|c|}
\hline Date & $\begin{array}{l}\text { Lake } \\
\text { level } \\
\text { (feet) }\end{array}$ & $\begin{array}{c}\text { Lake level } \\
\text { rounded to } \\
\text { nearest } 0.1 \\
\text { (feet) }\end{array}$ & $\begin{array}{c}\text { Source } \\
\text { of } \\
\text { data }^{1}\end{array}$ & $\begin{array}{l}\text { Applied } \\
\text { datum } \\
\text { correction } \\
\text { (feet) }\end{array}$ \\
\hline \multicolumn{5}{|c|}{ Waubay Lake-Continued } \\
\hline $05-01-69$ & $1,785.4$ & $1,785.4$ & $\mathrm{~F} 2$ & -- \\
\hline $10-01-69$ & 1.784 .48 & $1,784.5$ & G & -- \\
\hline $04-01-70$ & 1.784 .98 & $1,785.0$ & $\mathrm{G}$ & -- \\
\hline $05-01-70$ & 1,785 & $1,785.0$ & F2 & -- \\
\hline $10-01-70$ & 1.783 .84 & $1,783.8$ & $\mathrm{G}$ & -- \\
\hline $10-01-70$ & $1,783.4$ & $1,783.4$ & F2 & -- \\
\hline 04-01-71 & $1,784.66$ & $1,784.7$ & $\mathrm{G}$ & -- \\
\hline 05-01-71 & $1,784.6$ & $1,784.6$ & $\mathrm{~F} 2$ & -- \\
\hline $10-01-71$ & 1.784 .18 & $1,784.2$ & $\mathrm{G}$ & -- \\
\hline $05-01-72$ & 1.785 .1 & $1,785.1$ & $\mathrm{~F} 2$ & -- \\
\hline $10-01-72$ & $1,786.1$ & $1,786.1$ & $\mathrm{~F} 2$ & -- \\
\hline 05-01-73 & $1,785.9$ & $1,785.9$ & $\mathrm{~F} 2$ & -- \\
\hline $10-01-73$ & $1,784.7$ & $1,784.7$ & $\mathrm{~F} 2$ & -- \\
\hline 04-01-74 & $1,785.5$ & $1,785.5$ & $\mathrm{G}$ & -- \\
\hline $05-01-74$ & $1,785.5$ & $1,785.5$ & $\mathrm{~F} 2$ & -- \\
\hline $10-01-74$ & $1,783.77$ & $1,783.8$ & G & - \\
\hline $04-01-75$ & $1,784.18$ & $1,784.2$ & $\mathrm{G}$ & -- \\
\hline $05-01-75$ & $1,784.2$ & $1,784.2$ & $\mathrm{~F} 2$ & -- \\
\hline $10-01-75$ & $1,781.8$ & $1,781.8$ & G & -- \\
\hline $04-01-76$ & $1,782.95$ & $1,783.0$ & $\mathrm{G}$ & - \\
\hline $05-01-76$ & $1,782.93$ & $1,782.9$ & $\mathrm{~F} 2$ & -2.77 \\
\hline $10-01-76$ & $1,780.45$ & $1,780.5$ & $\mathrm{G}$ & -- \\
\hline $10-01-76$ & $1,780.63$ & $1,780.6$ & $\mathrm{~F} 2$ & -2.77 \\
\hline 04-01-77 & $1,781.39$ & $1,781.4$ & $\mathrm{G}$ & -- \\
\hline $05-01-77$ & $1,781.4$ & $1,781.4$ & $\mathrm{~F} 2$ & -- \\
\hline $10-01-77$ & 1.781 .22 & $1,781.2$ & $\mathrm{G}$ & -- \\
\hline 04-01-78 & $1,781.87$ & $1,781.9$ & G & -- \\
\hline $05-01-78$ & $1,781.9$ & $1,781.9$ & $\mathrm{~F} 2$ & -- \\
\hline $10-01-78$ & $1,782.09$ & $1,782.1$ & $\mathrm{G}$ & -- \\
\hline $10-01-78$ & $1,782.2$ & $1,782.2$ & $\mathrm{~F} 2$ & -- \\
\hline $04-01-79$ & $1,783.55$ & $1,783.6$ & $\mathrm{G}$ & -- \\
\hline 05-01-79 & $1,783.9$ & $1,783.9$ & $\mathrm{~F} 2$ & -- \\
\hline $10-01-79$ & 1.783 .6 & $1,783.6$ & G & -- \\
\hline $10-01-79$ & $1,783.9$ & $1,783.9$ & $\mathrm{~F} 2$ & - \\
\hline $04-01-80$ & $1,784.03$ & $1,784.0$ & $\mathrm{G}$ & -- \\
\hline $05-01-80$ & $1,783.6$ & $1,783.6$ & $\mathrm{~F} 2$ & -- \\
\hline
\end{tabular}

\begin{tabular}{|c|c|c|c|c|}
\hline Date & $\begin{array}{l}\text { Lake } \\
\text { level } \\
\text { (feet) }\end{array}$ & $\begin{array}{c}\text { Lake level } \\
\text { rounded to } \\
\text { nearest } 0.1 \\
\text { (feet) }\end{array}$ & $\begin{array}{c}\text { Souri:e } \\
\text { of } \\
\text { data }^{1}\end{array}$ & $\begin{array}{c}\text { Applied } \\
\text { datum } \\
\text { correction } \\
\text { (feet) }\end{array}$ \\
\hline
\end{tabular}

Waubay Lake-Continued

$10-01-80 \quad 1,782.95 \quad 1,783.0 \quad G$

04-01-81 $1,782.67 \quad 1,782.7 \quad$ G

05-01-81 $\quad 1.782 .7 \quad 1,782.7 \quad$ F2

$10-01-81 \quad 1,781.41 \quad 1,781.4 \quad$ G

04-01-82 $1,781.83 \quad 1,781.8 \quad G$

$\begin{array}{llll}05-01-82 & 1,781.9 & 1,781.9 & F 2\end{array}$

$\begin{array}{llll}10-01-82 & 1,781.1 & 1,781.1 & F 2\end{array}$

$\begin{array}{lll}11-01-82 & 1,781.26 & 1,781.3 \quad G\end{array}$

$\begin{array}{llll}04-01-83 & 1,781.7 & 1,781.7 & G\end{array}$

$\begin{array}{llll}10-01-83 & 1,780.55 & 1.780 .6 & G\end{array}$

10-11-83 $1,780.5 \quad 1,780.5 \quad \mathrm{~A} 1$

05-01-84 1,781.27 $1,781.3 \quad$ G

$\begin{array}{llll}10-01-84 & 1,780.87 & 1,780.9 & \text { G }\end{array}$

10-09-84 $1,781.6 \quad 1,781.6 \quad$ A1

$\begin{array}{llll}11-07-84 & 1,781.1 & 1,781.1 & \text { B1 }\end{array}$

04-01-85 $1,781.56 \quad 1,781.6 \quad G$

04-17-85 $1.781 .6 \quad 1,781.6 \quad$ A1

$\begin{array}{llll}10-01-85 & 1,780.92 & 1,780.9 & \text { G }\end{array}$

11-01-85 $1,780.9 \quad 1,780.9 \quad$ A1

04-01-86 $1.782 .25 \quad 1,782.3 \quad$ G

04-21-86 $1,782.2 \quad 1,782.2 \quad$ A

09-24-86 1,785.2 $1,785.2 \quad$ A1

$10-01-86 \quad 1,785.48 \quad 1,785.5 \quad G$

04-01-87 $1,787.7 \quad 1,787.7 \quad$ G

04-23-87 $1,787.5 \quad 1,787.5 \quad$ A1

$\begin{array}{llll}10-01-87 & 1,786.4 & 1,786.4 & G\end{array}$

$\begin{array}{llll}10-07-87 & 1,786.3 & 1,786.3 & \text { A1 }\end{array}$

04-01-88 $1.785 .97 \quad 1,786.0 \quad$ G

04-20-88 $\quad 1,785.9 \quad 1,785.9 \quad$ A1

09-21-88 $1.784 .6 \quad 1,784.6 \quad$ A

$11-01-88 \quad 1.784 .52 \quad 1,784.5 \quad G$

04-28-89 $1,785.3 \quad 1,785.3 \quad$ A1

05-01-89 $\quad 1,785.35 \quad 1,785.4 \quad G$

10-18-89 $1,784.4 \quad 1,784.4 \quad$ A1

11-01-89 $1,784.29 \quad 1,784.3 \quad G$

05-02-90 $1,784.6 \quad 1,784.6 \quad$ A1 
Table B1. Historic lake levels for the 10 major lakes of the Waubay Lakes Chain-Continued

[Lake levels in feet above sea level; --, none]

\begin{tabular}{|c|c|c|c|c|}
\hline Date & $\begin{array}{l}\text { Lake } \\
\text { level } \\
\text { (feet) }\end{array}$ & $\begin{array}{c}\text { Lake level } \\
\text { rounded to } \\
\text { nearest } 0.1 \\
\text { (feet) }\end{array}$ & $\begin{array}{c}\text { Source } \\
\text { of } \\
\text { data }^{1}\end{array}$ & $\begin{array}{l}\text { Applied } \\
\text { datum } \\
\text { correction } \\
\text { (feet) }\end{array}$ \\
\hline \multicolumn{5}{|c|}{ Waubay Lake-Continued } \\
\hline $06-01-90$ & $1,784.29$ & $1,784.3$ & G & -- \\
\hline $09-21-90$ & 1.783 .9 & $1,783.9$ & Al & -- \\
\hline $11-01-90$ & $1,783.05$ & $1,783.1$ & G & -- \\
\hline 04-01-91 & $1,783.05$ & $1,783.1$ & G & -- \\
\hline $05-01-91$ & $1,784.1$ & 1.784 .1 & A1 & -- \\
\hline $10-02-91$ & $1,784.3$ & $1,784.3$ & Al & -- \\
\hline 04-29-92 & $1,784.2$ & $1,784.2$ & $\mathrm{~A} 1$ & -- \\
\hline $09-16-92$ & 1.783 .9 & 1.783 .9 & $\mathrm{~A} 1$ & -- \\
\hline $05-12-93$ & $1,784.3$ & $1,784.3$ & A1 & -- \\
\hline $09-22-93$ & 1.787 .6 & 1.787 .6 & A1 & -- \\
\hline $05-01-94$ & $1,790.6$ & $1,790.6$ & G & -- \\
\hline 05-04-94 & $1,790.5$ & $1,790.5$ & $\mathrm{~A} 1$ & -- \\
\hline 09-14-94 & 1,791 & $1,791.0$ & $\mathrm{~A} 1$ & -- \\
\hline $10-01-94$ & $1,790.87$ & $1,790.9$ & G & -- \\
\hline 05-01-95 & $1,792.86$ & $1,792.9$ & $\mathrm{G}$ & -- \\
\hline $05-11-95$ & 1.792 .9 & $1,792.9$ & $\mathrm{~A} 1$ & -- \\
\hline $10-01-95$ & $1,794.08$ & $1,794.1$ & $\mathrm{G}$ & -- \\
\hline $10-11-95$ & $1,794.1$ & $1,794.1$ & $\mathrm{~A} 1$ & -- \\
\hline $04-01-96$ & $1,795.87$ & $1,795.9$ & G & -- \\
\hline $05-08-96$ & $1,796.1$ & $1,796.1$ & $\mathrm{~A} 1$ & -- \\
\hline $06-05-96$ & $1,797.2$ & $1,797.2$ & B1 & -- \\
\hline 07-01-96 & $1,796.8$ & $1,796.8$ & B1 & -- \\
\hline $07-29-96$ & $1,796.6$ & $1,796.6$ & B1 & -- \\
\hline 09-04-96 & $1,796.3$ & $1,796.3$ & B1 & -- \\
\hline $10-01-96$ & $1,796.86$ & $1,796.9$ & G & -- \\
\hline $10-09-96$ & $1,796.2$ & $1,796.2$ & A1 & -- \\
\hline 04-01-97 & $1,798.3$ & $1,798.3$ & $\mathrm{G}$ & -- \\
\hline 04-10-97 & $1,797.5$ & $1,797.5$ & B1 & -- \\
\hline $04-11-97$ & $1,797.5$ & $1,797.5$ & B1 & -- \\
\hline 04-14-97 & $1,798.3$ & $1,798.3$ & B1 & -- \\
\hline 04-15-97 & $1,798.4$ & $1,798.4$ & B1 & -- \\
\hline 04-16-97 & $1,798.4$ & $1,798.4$ & B1 & -- \\
\hline $04-17-97$ & $1,798.4$ & $1,798.4$ & B1 & -- \\
\hline 04-18-97 & $1,798.5$ & 1.798 .5 & B1 & -- \\
\hline $04-21-97$ & $1,798.7$ & $1,798.7$ & B1 & -- \\
\hline $04-22-97$ & 1.798 .7 & $1,798.7$ & B1 & -- \\
\hline
\end{tabular}

\begin{tabular}{|c|c|c|c|c|}
\hline Date & $\begin{array}{l}\text { Lake } \\
\text { level } \\
\text { (feet) }\end{array}$ & $\begin{array}{l}\text { Lake level } \\
\text { rounded to } \\
\text { nearest } 0.1 \\
\text { (feet) }\end{array}$ & $\begin{array}{c}\text { Source } \\
\text { of } \\
\text { data }^{1}\end{array}$ & $\begin{array}{l}\text { Applied } \\
\text { datum } \\
\text { correction } \\
\text { (fnet) }\end{array}$ \\
\hline \multicolumn{5}{|c|}{ Waubay Lake-Continued } \\
\hline $04-25-97$ & $1,798.9$ & $1,798.9$ & B1 & -- \\
\hline 04-28-97 & $1,799.1$ & $1,799.1$ & B1 & -- \\
\hline $05-01-97$ & $1,799.2$ & $1,799.2$ & B1 & -- \\
\hline $05-05-97$ & $1,799.5$ & $1,799.5$ & B1 & -- \\
\hline $05-09-97$ & $1,799.6$ & $1,799.6$ & B1 & -- \\
\hline $05-12-97$ & $1,799.7$ & $1,799.7$ & B1 & -- \\
\hline $05-16-97$ & $1,799.49$ & $1,799.5$ & $\mathrm{C}$ & - \\
\hline $05-20-97$ & 1.799 .2 & $1,799.2$ & A1 & -- \\
\hline 06-09-97 & $1,799.6$ & $1,799.6$ & B1 & -- \\
\hline $10-01-97$ & $1,800.08$ & $1,800.1$ & $\mathrm{G}$ & -- \\
\hline $10-08-97$ & $1,799.4$ & $1,799.4$ & A1 & -- \\
\hline $11-14-97$ & $1,799.98$ & $1,800.0$ & D & -- \\
\hline 04-14-98 & $1,801.3$ & $1,801.3$ & A1 & -- \\
\hline 04-14-98 & $1,800.81$ & $1,800.8$ & B1 & -- \\
\hline 04-20-98 & $1,801.43$ & $1,801.4$ & D & -- \\
\hline 04-20-98 & $1,800.9$ & $1,800.9$ & B1 & -- \\
\hline 04-27-98 & 1.801 .9 & $1,801.9$ & D & -- \\
\hline $04-27-98$ & $1,801.37$ & $1,801.4$ & B1 & -- \\
\hline 04-28-98 & $1,801.9$ & $1,801.9$ & D & -- \\
\hline $04-28-98$ & $1,801.37$ & $1,801.4$ & B1 & -- \\
\hline $05-04-98$ & $1,801.6$ & $1,801.6$ & B1 & -- \\
\hline $05-04-98$ & $1,801.95$ & $1,802.0$ & D & -- \\
\hline 05-04-98 & $1,801.42$ & $1,801.4$ & $\mathbf{U}$ & -- \\
\hline $05-05-98$ & 1.801 .95 & $1,802.0$ & D & -- \\
\hline 05-07-98 & $1,801.94$ & $1,801.9$ & D & -- \\
\hline 05-07-98 & $1,801.42$ & $1,801.4$ & B1 & -- \\
\hline $05-11-98$ & $1,801.98$ & 1.802 .0 & D & -- \\
\hline $05-11-98$ & $1,802.02$ & $1,802.0$ & D & -- \\
\hline $05-12-98$ & $1,802.4$ & $1,802.4$ & D & -- \\
\hline $05-12-98$ & $1,801.9$ & $1,801.9$ & B1 & -- \\
\hline $05-15-98$ & $1,802.48$ & $1,802.5$ & D & -- \\
\hline 05-18-98 & $1,802.59$ & $1,802.6$ & D & -- \\
\hline $05-18-98$ & $1,802.06$ & $1,802.1$ & B1 & - \\
\hline 05-20-98 & $1,802.6$ & $1,802.6$ & D & -- \\
\hline $05-20-98$ & $1,802.2$ & $1,802.2$ & A1 & -- \\
\hline $05-25-98$ & $1,802.3$ & $1,802.3$ & B1 & -- \\
\hline
\end{tabular}


Table B1. Historic lake levels for the 10 major lakes of the Waubay Lakes Chain-Continued

[Lake levels in feet above sea level; --, none]

\begin{tabular}{ccccc}
\hline Date & $\begin{array}{c}\text { Lake } \\
\text { level } \\
\text { (feet) }\end{array}$ & $\begin{array}{c}\text { Lake level } \\
\text { rounded to } \\
\text { nearest 0.1 } \\
\text { (feet) }\end{array}$ & $\begin{array}{c}\text { Source } \\
\text { of } \\
\text { data }{ }^{1}\end{array}$ & $\begin{array}{c}\text { Applied } \\
\text { datum } \\
\text { correction } \\
\text { (feet) }\end{array}$ \\
\hline \multicolumn{5}{c}{ Waubay Lake-Continued } \\
$05-26-98$ & $1,802.68$ & $1,802.7$ & D & -- \\
$05-29-98$ & 1.802 .3 & $1,802.3$ & B1 & -- \\
$06-02-98$ & 1.802 .3 & $1,802.3$ & B1 & -- \\
$06-08-98$ & $1,802.2$ & $1,802.2$ & B1 & -- \\
$06-15-98$ & $1,802.4$ & $1,802.4$ & B1 & -- \\
$06-16-98$ & $1,802.4$ & $1,802.4$ & B1 & -- \\
$06-22-98$ & $1,802.4$ & $1,802.4$ & B1 & -- \\
$06-29-98$ & $1,802.5$ & $1,802.5$ & B1 & -- \\
$07-06-98$ & $1,802.6$ & $1,802.6$ & B1 & - \\
$07-20-98$ & $1,802.5$ & $1,802.5$ & B1 & - \\
$07-27-98$ & $1,802.3$ & $1,802.3$ & B1 & - \\
$08-05-98$ & $1,802.3$ & $1,802.3$ & B1 & - \\
$08-10-98$ & $1,802.2$ & $1,802.2$ & B1 & - \\
$08-21-98$ & 1,802 & $1,802.0$ & B1 & - \\
$08-28-98$ & $1,802.1$ & $1,802.1$ & B1 & - \\
$11-13-98$ & $1,802.13$ & $1,802.1$ & B1 & - \\
$03-23-99$ & $1,802.7$ & $1,802.7$ & B1 & - \\
$04-07-99$ & $1,802.91$ & $1,802.9$ & B1 & - \\
\hline 15 & & &
\end{tabular}

${ }^{1}$ Sources of lake-level data:

A1, Day Conservation District Notes (day/month data);

A2, Day Conservation District Notes (month data; assume first of the month);

B1, South Dakota Department of Environment and Natural Resources (day/month data);

C, U.S. Army Corps of Engineers from Clark Engineering Study (day/month data);

D, Waubay National Wildlife Refuge (day/month data);

E, South Dakota Geological Survey though South Dakota Department of Environment and Natural Resources (day/ month data);

F1, U.S. Army Corps of Engineers (day/month data);

F2, U.S. Army Corps of Engineers (month data; assume first of the month):

F3, U.S. Army Corps of Engineers (year data; assume June 15);

G, Waubay National Wildlife Refuge (month data; assume first of the month);

G1, Waubay National Wildlife Refuge (year data; assume June 15);

H, Carter and Thompson, 1999;

U, Unknown (year data; assume June 15). 


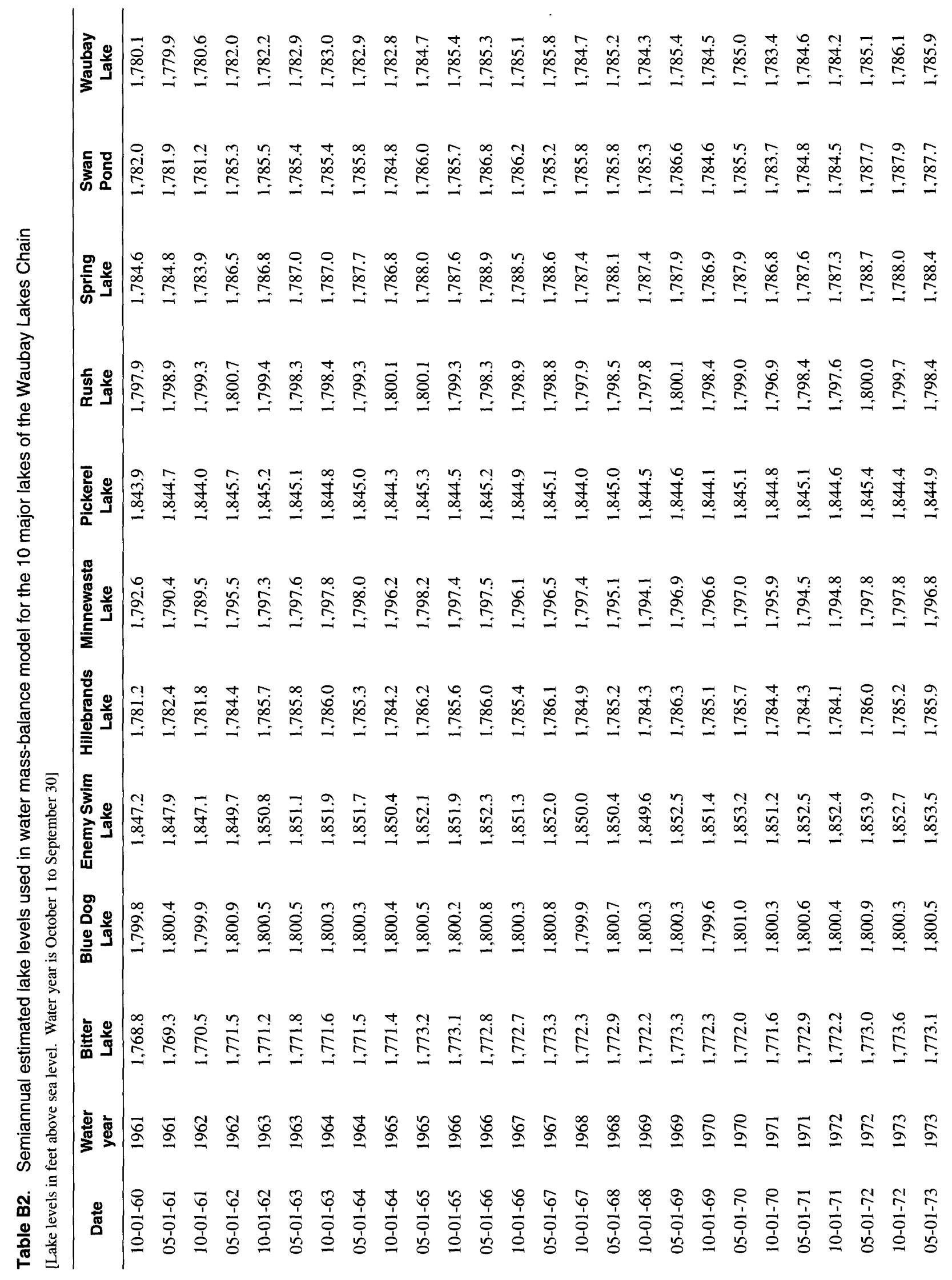




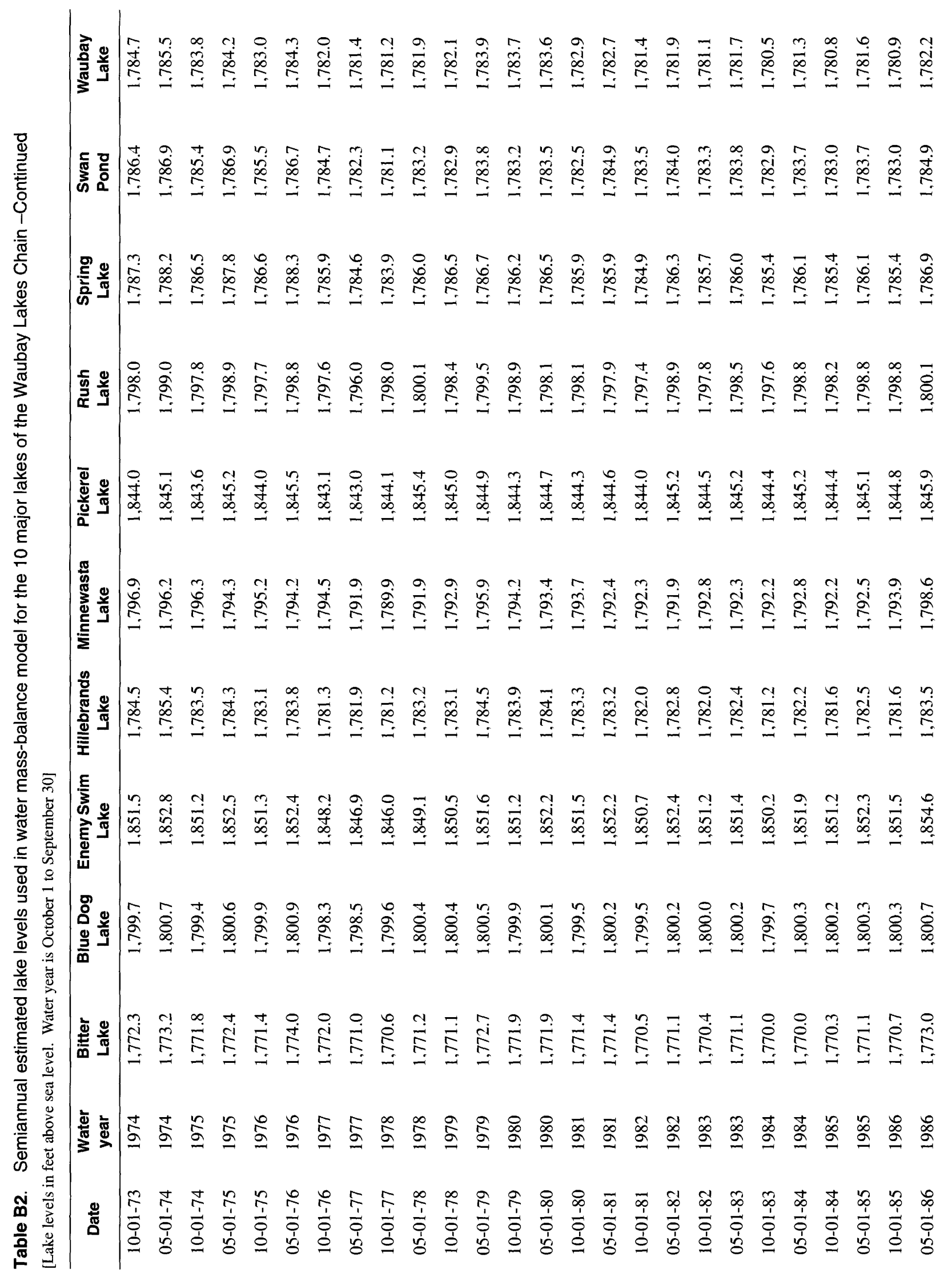




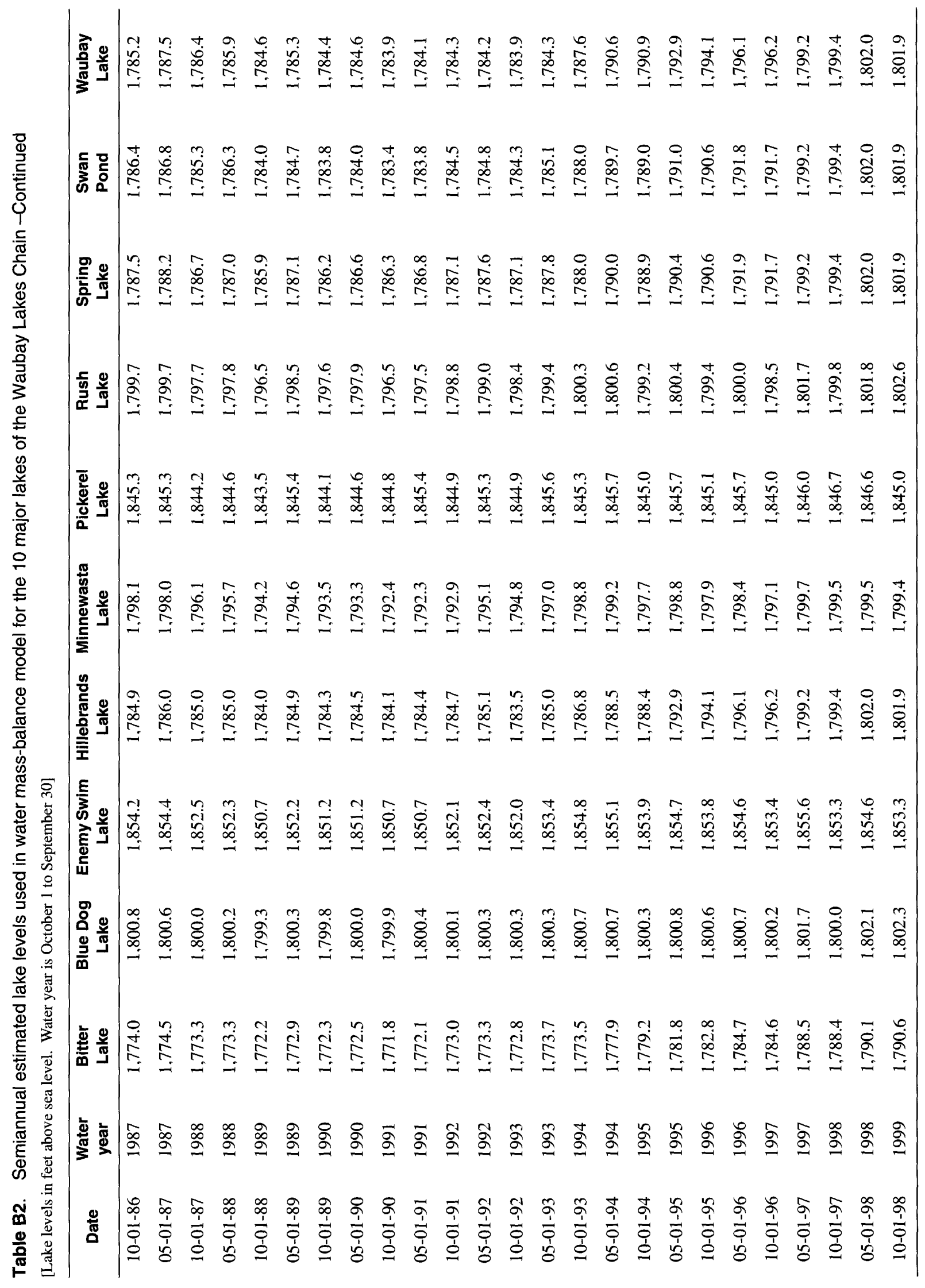


Table B3. Precipitation data, in inches, used in water mass-balance model for the Waubay Lakes Chain

[Precipitation at Waubay National Wildlife Refuge station, 1961-98. Source: National Climatic Data Center (1998) and U.S. National Oceanic and Atmospheric Administration (1998-99)]

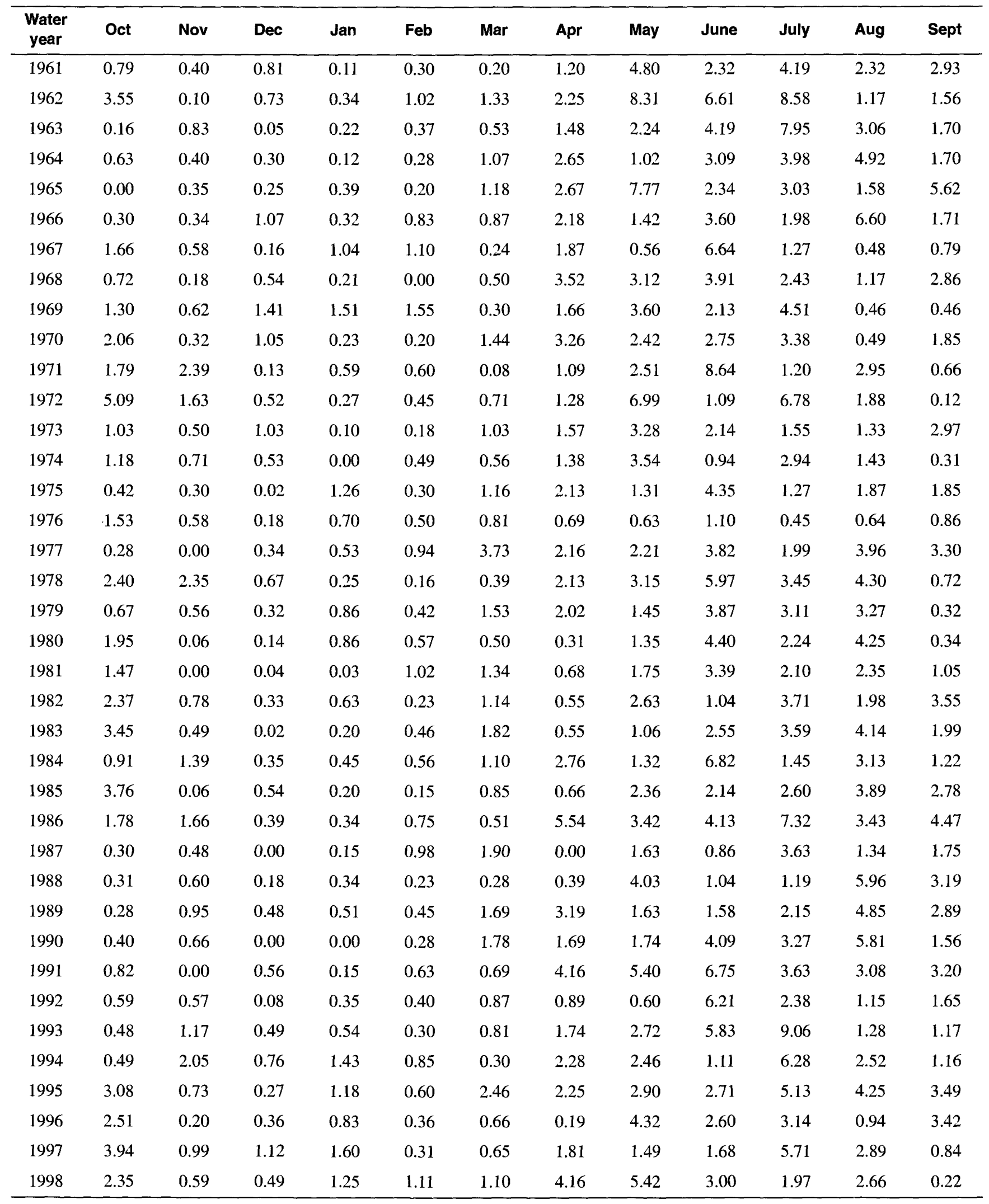


Table B4. Evaporation data, in inches, used in water mass-balance model for the Waubay Lakes Chain

[Estimated lake evaporation at Waubay. Source: Agricultural and Biosystems Engineering Department, 1999]

\begin{tabular}{|c|c|c|c|c|c|c|c|c|c|c|c|c|}
\hline $\begin{array}{l}\text { Water } \\
\text { year }\end{array}$ & Oct & Nov & Dec & Jan & Feb & Mar & Apr & May & June & July & Aug & Sent \\
\hline 1961 & 2.56 & 0.83 & 0.42 & 0.25 & 0.49 & 1.25 & 2.49 & 3.75 & 4.57 & 4.87 & 4.67 & 3.75 \\
\hline 1962 & 2.53 & 0.82 & 0.42 & 0.24 & 0.46 & 1.19 & 2.36 & 3.56 & 4.34 & 4.62 & 4.44 & 3.56 \\
\hline 1963 & 2.40 & 0.78 & 0.40 & 0.26 & 0.50 & 1.29 & 2.58 & 3.89 & 4.73 & 5.05 & 4.84 & 3.88 \\
\hline 1964 & 2.62 & 0.85 & 0.43 & 0.27 & 0.52 & 1.34 & 2.67 & 4.02 & 4.90 & 5.22 & 5.01 & 4.02 \\
\hline 1965 & 2.71 & 0.88 & 0.45 & 0.25 & 0.48 & 1.24 & 2.47 & 3.73 & 4.54 & 4.84 & 4.65 & 3.73 \\
\hline 1966 & 2.52 & 0.81 & 0.42 & 0.31 & 0.60 & 1.53 & 3.04 & 4.59 & 5.59 & 5.96 & 5.72 & 4.59 \\
\hline 1967 & 3.10 & 1.00 & 0.51 & 0.27 & 0.53 & 1.35 & 2.69 & 4.05 & 4.94 & 5.26 & 5.05 & 4.05 \\
\hline 1968 & 2.73 & 0.88 & 0.45 & 0.27 & 0.52 & 1.33 & 2.64 & 3.98 & 4.85 & 5.17 & 4.96 & 3.98 \\
\hline 1969 & 2.69 & 0.87 & 0.45 & 0.25 & 0.49 & 1.26 & 2.51 & 3.79 & 4.62 & 4.92 & 4.72 & 3.79 \\
\hline 1970 & 2.56 & 0.83 & 0.42 & 0.29 & 0.56 & 1.45 & 2.88 & 4.35 & 5.29 & 5.64 & 5.41 & 4.34 \\
\hline 1971 & 2.93 & 0.95 & 0.49 & 0.30 & 0.58 & 1.48 & 2.96 & 4.46 & 5.43 & 5.79 & 5.56 & 4.45 \\
\hline 1972 & 3.01 & 0.97 & 0.50 & 0.24 & 0.46 & 1.17 & 2.34 & 3.53 & 4.29 & 4.58 & 4.39 & 3.52 \\
\hline 1973 & 2.38 & 0.77 & 0.39 & 0.29 & 0.56 & 1.44 & 2.87 & 4.33 & 5.27 & 5.62 & 5.39 & 4.32 \\
\hline 1974 & 2.92 & 0.94 & 0.48 & 0.29 & 0.56 & 1.45 & 2.88 & 4.34 & 5.29 & 5.64 & 5.41 & 4.34 \\
\hline 1975 & 2.93 & 0.95 & 0.49 & 0.27 & 0.53 & 1.35 & 2.69 & 4.06 & 4.94 & 5.27 & 5.06 & 4.05 \\
\hline 1976 & 2.74 & 0.88 & 0.45 & 0.37 & 0.72 & 1.84 & 3.67 & 5.54 & 6.74 & 7.19 & 6.90 & 5.53 \\
\hline 1977 & 3.73 & 1.21 & 0.62 & 0.30 & 0.58 & 1.49 & 2.96 & 4.47 & 5.44 & 5.80 & 5.57 & 4.46 \\
\hline 1978 & 3.01 & 0.97 & 0.50 & 0.29 & 0.55 & 1.41 & 2.81 & 4.24 & 5.16 & 5.51 & 5.28 & 4.24 \\
\hline 1979 & 2.86 & 0.92 & 0.47 & 0.25 & 0.48 & 1.23 & 2.45 & 3.70 & 4.50 & 4.80 & 4.61 & 3.69 \\
\hline 1980 & 2.49 & 0.81 & 0.41 & 0.28 & 0.55 & 1.40 & 2.79 & 4.21 & 5.12 & 5.46 & 5.24 & 4.20 \\
\hline 1981 & 2.84 & 0.92 & 0.47 & 0.26 & 0.51 & 1.30 & 2.58 & 3.89 & 4.74 & 5.05 & 4.85 & 3.89 \\
\hline 1982 & 2.62 & 0.85 & 0.44 & 0.24 & 0.46 & 1.18 & 2.35 & 3.55 & 4.32 & 4.60 & 4.42 & 3.54 \\
\hline 1983 & 2.39 & 0.77 & 0.40 & 0.27 & 0.51 & 1.32 & 2.62 & 3.96 & 4.82 & 5.14 & 4.93 & 3.95 \\
\hline 1984 & 2.67 & 0.86 & 0.44 & 0.27 & 0.51 & 1.32 & 2.62 & 3.95 & 4.81 & 5.13 & 4.92 & 3.95 \\
\hline 1985 & 2.66 & 0.86 & 0.44 & 0.26 & 0.50 & 1.29 & 2.56 & 3.87 & 4.71 & 5.02 & 4.82 & 3.86 \\
\hline 1986 & 2.61 & 0.84 & 0.43 & 0.26 & 0.50 & 1.28 & 2.54 & 3.84 & 4.67 & 4.98 & 4.78 & 3.83 \\
\hline 1987 & 2.59 & 0.84 & 0.43 & 0.27 & 0.53 & 1.35 & 2.68 & 4.05 & 4.93 & 5.25 & 5.04 & 4.04 \\
\hline 1988 & 2.73 & 0.88 & 0.45 & 0.34 & 0.66 & 1.68 & 3.34 & 5.04 & 6.14 & 6.55 & 6.28 & 5.04 \\
\hline 1989 & 3.40 & 1.10 & 0.56 & 0.28 & 0.54 & 1.39 & 2.77 & 4.17 & 5.08 & 5.42 & 5.20 & 4.17 \\
\hline 1990 & 2.81 & 0.91 & 0.47 & 0.29 & 0.56 & 1.43 & 2.86 & 4.31 & 5.25 & 5.59 & 5.37 & 4.30 \\
\hline 1991 & 2.91 & 0.94 & 0.48 & 0.27 & 0.53 & 1.35 & 2.69 & 4.06 & 4.95 & 5.27 & 5.06 & 4.06 \\
\hline 1992 & 2.74 & 0.89 & 0.45 & 0.24 & 0.45 & 1.17 & 2.32 & 3.50 & 4.26 & 4.54 & 4.36 & 3.50 \\
\hline 1993 & 2.36 & 0.76 & 0.39 & 0.22 & 0.43 & 1.11 & 2.21 & 3.34 & 4.07 & 4.34 & 4.16 & 3.34 \\
\hline 1994 & 2.25 & 0.73 & 0.37 & 0.25 & 0.48 & 1.23 & 2.46 & 3.71 & 4.52 & 4.82 & 4.62 & 3.71 \\
\hline 1995 & 2.50 & 0.81 & 0.41 & 0.24 & 0.46 & 1.17 & 2.34 & 3.53 & 4.30 & 4.58 & 4.40 & 3.52 \\
\hline 1996 & 2.38 & 0.77 & 0.39 & 0.21 & 0.42 & 1.06 & 2.12 & 3.20 & 3.89 & 4.15 & 3.98 & 3.19 \\
\hline 1997 & 2.15 & 0.70 & 0.36 & 0.26 & 0.50 & 1.28 & 2.56 & 3.86 & 4.70 & 5.01 & 4.80 & 3.85 \\
\hline 1998 & 2.60 & 0.84 & 0.43 & 0.24 & 0.47 & 1.20 & 2.39 & 3.61 & 4.40 & 4.69 & 4.50 & 3.61 \\
\hline
\end{tabular}


Table B5. Areas and volumes for the 10 major lakes of the Waubay Lakes Chain [Lake levels in feet above sea level. Lake area/capacity tables at 1-foot intervals]

\begin{tabular}{|c|c|c|}
\hline $\begin{array}{l}\text { Lake level } \\
\text { (feet) }\end{array}$ & $\begin{array}{c}\text { Area } \\
\text { (acres) }\end{array}$ & $\begin{array}{c}\text { Volume } \\
\text { (acre-feet) }\end{array}$ \\
\hline \multicolumn{3}{|c|}{ Bitter Lake } \\
\hline 1,769 & 0 & 0 \\
\hline 1.770 & $1,225.5$ & 547.1 \\
\hline 1,771 & $2,173.3$ & $2,278.9$ \\
\hline 1,772 & $2,806.5$ & $4,790.1$ \\
\hline 1,773 & $3,224.5$ & $7,820.5$ \\
\hline 1,774 & $3,492.9$ & $11,189.3$ \\
\hline 1,775 & $3,663.3$ & $14,773.7$ \\
\hline 1.776 & $3,777.8$ & $18,497.4$ \\
\hline 1,777 & $3,869.6$ & $22,321.8$ \\
\hline 1.778 & $3,964.3$ & $26,237.6$ \\
\hline 1,779 & $4,081.1$ & $30,257.9$ \\
\hline 1,780 & $4,233.3$ & $34,411.7$ \\
\hline 1,781 & $4,429.3$ & $38,739.1$ \\
\hline 1,782 & $4,674.5$ & $43,286.8$ \\
\hline 1,783 & $4,971.0$ & $48,105.2$ \\
\hline 1,784 & $5,319.4$ & $53,246.1$ \\
\hline 1,785 & $5,718.9$ & $58,761.1$ \\
\hline 1,786 & $6,167.7$ & $64,700.4$ \\
\hline 1,787 & $6,663.6$ & $71,112.2$ \\
\hline 1,788 & $7,204.0$ & $78,042.4$ \\
\hline 1,789 & $7,786.3$ & $85,534.2$ \\
\hline 1,790 & $8,407.8$ & $93,628.1$ \\
\hline 1,791 & $9,065.9$ & $102,362.0$ \\
\hline 1,792 & $9,758.0$ & $111,771.1$ \\
\hline 1,793 & $10,481.7$ & $121,888.5$ \\
\hline 1,794 & $11,234.9$ & $132,744.4$ \\
\hline 1,795 & $12,015.4$ & $144,367.4$ \\
\hline 1,796 & $12,821.4$ & $156,783.7$ \\
\hline 1,797 & $13,651.1$ & $170,018.0$ \\
\hline 1.798 & $14,503.0$ & $184,093.2$ \\
\hline 1,799 & $15,375.9$ & $199,031.0$ \\
\hline 1,800 & $16,268.6$ & $214,851.7$ \\
\hline 1.801 & $17,180.0$ & $231,574.4$ \\
\hline 1,802 & $18,109.5$ & $249,217.7$ \\
\hline 1,803 & 19.056 .5 & $267,799.3$ \\
\hline 1,804 & $20,020.4$ & $287,336.3$ \\
\hline 1,805 & $21,001.0$ & $307,845.6$ \\
\hline
\end{tabular}

\begin{tabular}{|c|c|c|}
\hline $\begin{array}{l}\text { Lake level } \\
\text { (feet) }\end{array}$ & $\begin{array}{c}\text { Area } \\
\text { (acres) }\end{array}$ & $\begin{array}{l}\text { Volume } \\
\text { (acre-feet) }\end{array}$ \\
\hline \multicolumn{3}{|c|}{ Bitter Lake-Continued } \\
\hline 1,806 & $21,998.2$ & $329,343.8$ \\
\hline 1,807 & $23,012.2$ & $351,847.6$ \\
\hline 1,808 & $24,043.0$ & $375,373.8$ \\
\hline 1,809 & $25,091.1$ & $399,939.3$ \\
\hline 1,810 & $26,157.0$ & $425,561.9$ \\
\hline 1,811 & $27,241.4$ & $452,259.5$ \\
\hline 1,812 & $28,345.2$ & $480,051.1$ \\
\hline 1,813 & $29,469.4$ & $508,956.7$ \\
\hline 1,814 & $30,615.2$ & $538,997.1$ \\
\hline 1,815 & $31,784.0$ & $570,194.8$ \\
\hline \multicolumn{3}{|c|}{ Blue Dog Lake } \\
\hline 1,791 & 0 & 0 \\
\hline 1,792 & 500.5 & 106.8 \\
\hline 1,793 & 889.6 & 831.8 \\
\hline 1,794 & $1,094.9$ & $1,831.5$ \\
\hline 1,795 & $1,236.7$ & $3,001.0$ \\
\hline 1,796 & $1,343.0$ & $4,293.2$ \\
\hline 1,797 & $1,426.3$ & $5,679.4$ \\
\hline 1,798 & $1,493.7$ & $7,140.5$ \\
\hline 1,799 & $1,550.0$ & $8,663.1$ \\
\hline 1,800 & $1,598.8$ & $10,238.0$ \\
\hline 1,801 & $1,643.0$ & $11,859.1$ \\
\hline 1,802 & $1,685.3$ & $13,523.3$ \\
\hline 1,803 & $1,728.0$ & $15,229.8$ \\
\hline 1,804 & $1,773.3$ & $16,980.1$ \\
\hline 1,805 & $1,823.3$ & $18,778.0$ \\
\hline 1,806 & $1,880.1$ & $20,629.0$ \\
\hline 1,807 & $1,945.1$ & $22,540.9$ \\
\hline 1.808 & $2,020.0$ & $24,522.6$ \\
\hline 1,809 & $2,105.8$ & $26,584.5$ \\
\hline 1,810 & $2,203.2$ & $28,738.1$ \\
\hline 1,811 & $2,312.2$ & $30,994.8$ \\
\hline 1,812 & $2,432.4$ & $33,366.2$ \\
\hline 1,813 & $2,562.8$ & $35,863.0$ \\
\hline 1,814 & $2,701.7$ & $38,494.6$ \\
\hline 1,815 & $2,847.0$ & $41,268.6$ \\
\hline
\end{tabular}


Table B5. Areas and volumes for the 10 major lakes of the Waubay Lakes Chain-Continued [Lake levels in feet above sea level. Lake area/capacity tables at 1-foot intervals]

\begin{tabular}{ccc}
\hline $\begin{array}{c}\text { Lake level } \\
\text { (feet) }\end{array}$ & $\begin{array}{c}\text { Area } \\
\text { (acres) }\end{array}$ & $\begin{array}{c}\text { Volume } \\
\text { (acre-feet) }\end{array}$ \\
\hline
\end{tabular}

Enemy Swim Lake

1,823

1,824

1,825

1,826

1,827

1,828

1,829

1,830

1.831

1,832

1,833

1,834

1,835

1,836

1,837

1,838

1,839

1,840

1,841

1,842

1,843

1,844

1,845

1,846

1,847

1,848

1,849

1,850

1,851

1,852

1,853

1,854

1,855

1,856

1,857

1,858

1,859

$$
0
$$$$
4.3
$$

64.5

134.0

208.3

286.1

366.5

449.1

533.8

620.2

708.3

797.9

889.0

981.4

$1,075.2$

$1,170.3$

$1,266.7$

$1,364.4$

$1,463.4$

$1,563.7$

$1,665.4$

$1,768.5$

$1,873.0$

$1,979.0$

2,086.4

2.195.3

2,305.7

$2,417.5$

$2,530.5$

2,644.7

2,759.6

2,874.9

$2,989.9$

$3,104.0$

$3,216.3$

3,325.6

$3,430.8$
0

0.2

33.3

132.1

302.9

549.9

875.9

$1,283.5$

$1,774.9$

$2,351.7$

$3,768.9$

$4,612.2$

$5,547.3$

$6,575.4$

7,698.1

$8,916.4$

$10,231.8$

$11,645.6$

$13,159.1$

14.773 .6

$16,490.4$

18,311.1

$20,237.0$

22.269.6

$24,410.3$

26,660.7

$29,022.2$

31.496 .1

$34,083.6$

$36,785.6$

$39,602.8$

$42,535.3$

$45,582.4$

$48,742.8$

$52,014.0$

$55,392.5$
3.015 .9

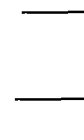

Lake level

(2)

Area

Area
(acres)

Enemy Swim Lake-Continued

1,860

$3,531.0$

$58,873.9$

1,861

$3,625.3$

$62,452.6$

1,862

$3,713.1$

$66,122.3$

1,863

$3,794.6$

$69,876.7$

1,864

$3,870.5$

$73,709.7$

1,865

$3,942.0$

$77,616.3$

Hillebrands Lake

1,766

1,767

0

0.1

3.0

14.5

39.9

80.3

131.6

187.6

242.2

291.7

334.5

370.7

401.1

426.8

449.1

468.9

487.1

504.4

521.1

537.7

554.4

571.3

588.6

606.4

624.6

643.2

662.5

682.2

702.4

723.1

1,795

1,792

1,793

1,794

1,795

1,790

, 791

0

0

1.1

8.9

34.8

93.7

198.9

358.4

573.6

841.1

$1,154.8$

$1,507.9$

1,894.3

2,308.5

2,746.7

3,205.9

$3,684.0$

$4,179.8$

4,692.6

$5,222.0$

$5,768.1$

$6,331.0$

$6,910.9$

7,508.4

$8,123.8$

$8,757.7$

$9,410.5$

$10,082.7$

$10,775.0$

$11,487.7$ 
Table B5. Areas and volumes for the 10 major lakes of the Waubay Lakes Chain-Continued

[Lake levels in feet above sea level. Lake area/capacity tables at 1-foot intervals]

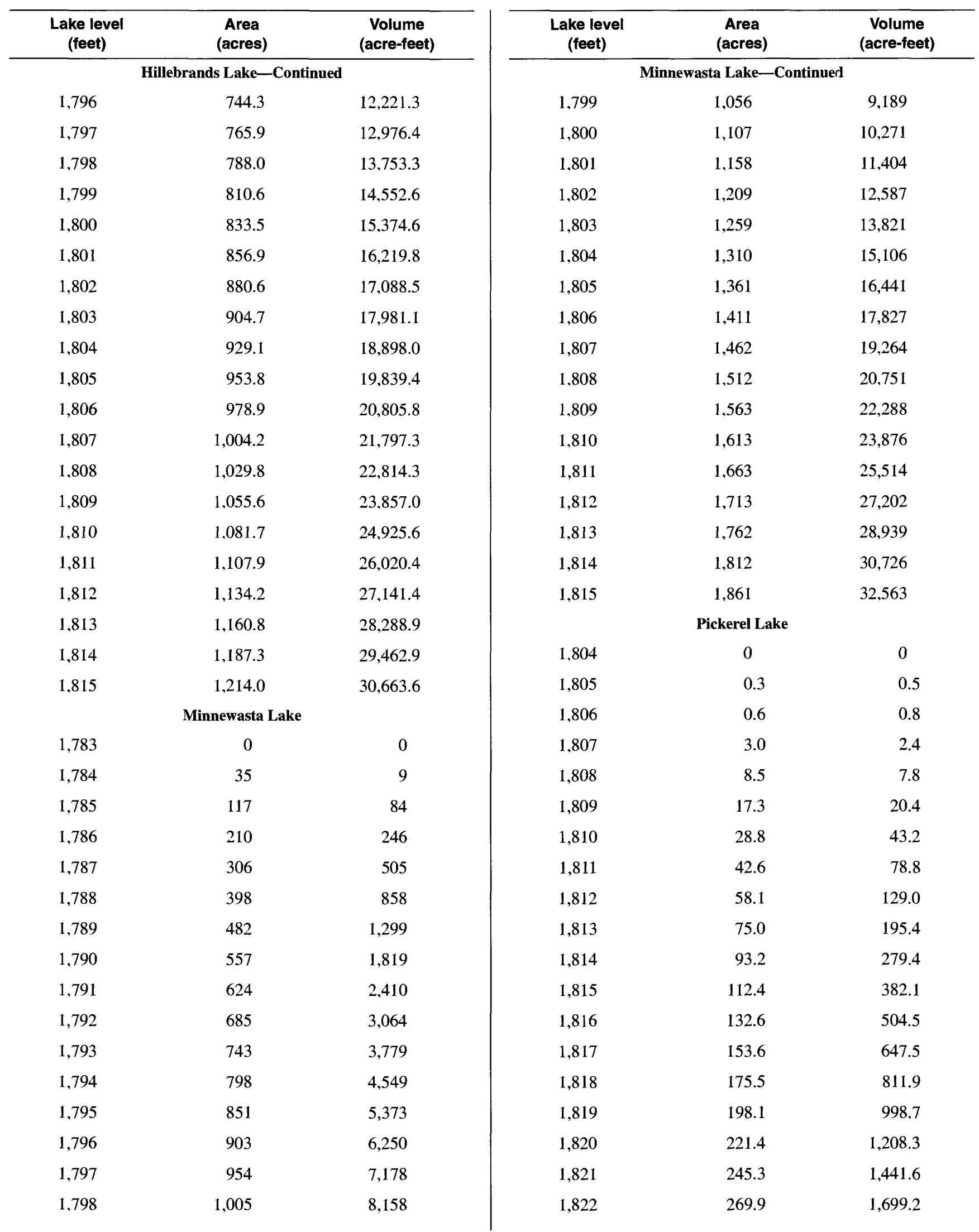


Table B5. Areas and volumes for the 10 major lakes of the Waubay Lakes Chain-Continued

[Lake levels in feet above sea level. Lake area/capacity tables at 1-foot intervals]

\begin{tabular}{|c|c|c|c|c|c|}
\hline $\begin{array}{l}\text { Lake level } \\
\text { (feet) }\end{array}$ & $\begin{array}{c}\text { Area } \\
\text { (acres) }\end{array}$ & $\begin{array}{c}\text { Volume } \\
\text { (acre-feet) }\end{array}$ & $\begin{array}{l}\text { Lake level } \\
\text { (feet) }\end{array}$ & $\begin{array}{c}\text { Area } \\
\text { (acres) }\end{array}$ & $\begin{array}{c}\text { Volume } \\
\text { (acre-feet) }\end{array}$ \\
\hline \multicolumn{3}{|c|}{ Pickerel Lake-Continued } & \multicolumn{3}{|c|}{ Rush Lake-Continued } \\
\hline 1,823 & 295.1 & $1,981.7$ & 1,795 & 2.070 & 2,934 \\
\hline 1,824 & 320.9 & $2,289.6$ & 1,796 & 2,391 & 5,178 \\
\hline 1,825 & 347.2 & $2,623.6$ & 1,797 & 2,622 & 7,687 \\
\hline 1,826 & 374.0 & $2,984.1$ & 1,798 & 2,833 & 10,415 \\
\hline 1,827 & 401.4 & $3,371.8$ & 1,799 & 3,041 & 13,352 \\
\hline 1,828 & 429.2 & $3,787.0$ & 1,800 & 3,249 & 16,498 \\
\hline 1,829 & 457.5 & $4,230.4$ & 1,801 & 3,455 & 19,850 \\
\hline 1,830 & 486.3 & $4,702.2$ & 1,802 & 3.659 & 23,408 \\
\hline 1,831 & 515.5 & $5,203.1$ & 1,803 & 3,860 & 27,168 \\
\hline 1,832 & 545.2 & $5,733.5$ & 1,804 & 4,057 & 31,127 \\
\hline 1,833 & 575.3 & $6,293.7$ & 1,805 & 4,251 & 35,281 \\
\hline 1,834 & 605.8 & $6,884.2$ & 1,806 & 4,441 & 39,627 \\
\hline 1,835 & 636.7 & $7,505.4$ & 1,807 & 4,627 & 44,161 \\
\hline 1,836 & 668.0 & $8,157.7$ & 1,808 & 4,810 & 48,879 \\
\hline 1,837 & 699.7 & $8,841.5$ & 1,809 & 4,989 & 53,779 \\
\hline 1,838 & 731.7 & $9,557.1$ & 1,810 & 5,166 & 58,857 \\
\hline 1,839 & 764.2 & $10,305.0$ & 1,811 & 5,339 & 64,110 \\
\hline 1,840 & 796.9 & $11,085.6$ & 1,812 & 5,510 & 69,534 \\
\hline 1,841 & 830.1 & $11,899.0$ & 1,813 & 5,677 & 75,128 \\
\hline 1,842 & 863.6 & $12,745.8$ & 1,814 & 5,842 & 80,888 \\
\hline 1,843 & 897.4 & $13,626.3$ & 1,815 & 6,004 & 86,811 \\
\hline 1,844 & 931.6 & $14,540.8$ & \multicolumn{3}{|c|}{ Spring Lake } \\
\hline 1,845 & 966.1 & $15,489.6$ & 1,776 & 0 & 0 \\
\hline 1,846 & $1,000.9$ & $16,473.0$ & 1,777 & 234.7 & 111.9 \\
\hline 1,847 & $1,036.0$ & $17,491.5$ & 1,778 & 438.7 & 451.1 \\
\hline 1,848 & $1,071.5$ & $18,545.2$ & 1,779 & 600.5 & 975.1 \\
\hline 1,849 & $1,107.2$ & $19,634.5$ & 1,780 & 709.0 & $1,634.0$ \\
\hline 1,850 & $1,143.3$ & $20,759.8$ & 1,781 & 775.5 & $2,379.1$ \\
\hline 1,851 & $1,179.7$ & $21,921.2$ & 1,782 & 816.8 & $3,176.6$ \\
\hline 1,852 & $1,216.3$ & $23,119.2$ & 1,783 & 845.8 & $4,008.6$ \\
\hline 1,853 & $1,253.3$ & $24,353.9$ & 1,784 & 869.8 & $4,866.6$ \\
\hline 1,854 & $1,290.5$ & $25,625.8$ & 1,785 & 892.3 & $5,747.7$ \\
\hline 1.855 & $1,328.0$ & $26,935.0$ & 1,786 & 914.9 & $6,651.2$ \\
\hline & Rush Lake & & 1,787 & 937.9 & $7,577.6$ \\
\hline 1,792 & 0 & 0 & 1,788 & 961.6 & $8,527.3$ \\
\hline 1,793 & 511 & 115 & 1,789 & 985.8 & $9,501.0$ \\
\hline 1,794 & 1,476 & 1,129 & 1,790 & $1,010.4$ & $10,499.1$ \\
\hline
\end{tabular}


Table B5. Areas and volumes for the 10 major lakes of the Waubay Lakes Chain-Continued [Lake levels in feet above sea level. Lake area/capacity tables at 1-foot intervals]

\begin{tabular}{|c|c|c|c|c|c|}
\hline $\begin{array}{l}\text { Lake level } \\
\text { (feet) }\end{array}$ & $\begin{array}{c}\text { Area } \\
\text { (acres) }\end{array}$ & $\begin{array}{c}\text { Volume } \\
\text { (acre-feet) }\end{array}$ & $\begin{array}{l}\text { Lake level } \\
\text { (feet) }\end{array}$ & $\begin{array}{c}\text { Area } \\
\text { (acres) }\end{array}$ & $\begin{array}{c}\text { Volume } \\
\text { (acre-feet) }\end{array}$ \\
\hline \multicolumn{3}{|c|}{ Spring Lake-Continued } & \multicolumn{3}{|c|}{ Swan Pond-Continued } \\
\hline 1,792 & $1,060.1$ & $12,569.6$ & 1,792 & 143.8 & $1,164.9$ \\
\hline 1,793 & 1.085 .0 & 13.642 .1 & 1,793 & 149.5 & $1,311.6$ \\
\hline 1,795 & $1,134.5$ & $15,861.7$ & 1,795 & 160.8 & $1,621.9$ \\
\hline 1,796 & $1,159.0$ & $17,008.5$ & 1,796 & 166.3 & $1,785.4$ \\
\hline 1,797 & $1,183.2$ & $18,179.6$ & 1,797 & 171.8 & 1.954 .5 \\
\hline 1,798 & $1,207.3$ & $19,374.9$ & 1,798 & 177.2 & $2,129.0$ \\
\hline 1,801 & $1,277.8$ & $23,103.1$ & 1,801 & 193.1 & $2,684.7$ \\
\hline 1,802 & $1,300.8$ & $24,392.4$ & 1,802 & 198.3 & $2,880.4$ \\
\hline 1,803 & $1,323.4$ & $25,704.5$ & 1,803 & 203.4 & $3,081.3$ \\
\hline 1,804 & $1,345.9$ & $27,039.2$ & 1,804 & 208.4 & $3,287.1$ \\
\hline 1,805 & $1,368.0$ & $28,396.1$ & 1,805 & 213.4 & $3,498.0$ \\
\hline 1.806 & $1,389.9$ & $29,775.1$ & 1.806 & 218.3 & $3,713.8$ \\
\hline 1,807 & $1,411.5$ & $31,175.8$ & 1,807 & 223.1 & $3,934.6$ \\
\hline 1,808 & $1,432.8$ & $32,597.9$ & 1,808 & 227.9 & $4,160.1$ \\
\hline 1,812 & $1,515.6$ & $38,496.0$ & 1,812 & 246.6 & $5,109.3$ \\
\hline 1.813 & $1,535.6$ & $40,021.6$ & 1,813 & 251.1 & $5,358.1$ \\
\hline 1,814 & $1,555.4$ & $41,567.2$ & 1,814 & 255.6 & $5,611.4$ \\
\hline 1,815 & $1,575.0$ & $43,132.4$ & 1,815 & 260.0 & $5,869.2$ \\
\hline \multicolumn{3}{|c|}{ Swan Pond } & \multicolumn{3}{|c|}{ Waubay Lake } \\
\hline 1,780 & 0 & 0 & 1,772 & 0 & 0 \\
\hline 1,781 & 28.1 & 12.7 & 1,773 & 406.6 & 104.3 \\
\hline 1,782 & 55.6 & 54.9 & 1,774 & $1,251.4$ & 924.9 \\
\hline 1.783 & 76.9 & 121.7 & 1,775 & $2,155.3$ & 2.627 .6 \\
\hline 1,784 & 91.2 & 206.3 & 1,776 & $3,018.3$ & $5,221.3$ \\
\hline 1,785 & 100.9 & 302.5 & 1,777 & $3,780.9$ & 8.630 .1 \\
\hline 1,786 & 108.2 & 407.2 & 1,778 & $4,438.1$ & 12.747 .7 \\
\hline 1,787 & 114.6 & 518.6 & 1,779 & $5,011.9$ & $17,478.5$ \\
\hline 1,788 & 120.5 & 636.2 & 1,780 & $5,529.0$ & $22,752.7$ \\
\hline 1,789 & 126.4 & 759.7 & 1,781 & $6,010.3$ & $28,524.6$ \\
\hline 1,790 & 132.2 & 889.0 & 1.782 & $6,470.3$ & 34.766 .3 \\
\hline
\end{tabular}


Table B5. Areas and volumes for the 10 major lakes of the Waubay Lakes Chain-Continued [Lake levels in feet above sea level. Lake area/capacity tables at 1-foot intervals]

\begin{tabular}{|c|c|c|}
\hline $\begin{array}{l}\text { Lake level } \\
\text { (feet) }\end{array}$ & $\begin{array}{c}\text { Area } \\
\text { (acres) }\end{array}$ & $\begin{array}{c}\text { Volume } \\
\text { (acre-feet) }\end{array}$ \\
\hline \multicolumn{3}{|c|}{ Waubay Lake-Continued } \\
\hline 1,783 & $6,917.8$ & $41,461.1$ \\
\hline 1,784 & $7,358.1$ & $48,599.5$ \\
\hline 1,785 & $7,794.1$ & $56,175.9$ \\
\hline 1,786 & $8,227.6$ & $64,186.9$ \\
\hline 1,787 & $8,659.3$ & $72,630.4$ \\
\hline 1,788 & $9,089.7$ & $81,505.0$ \\
\hline 1,789 & $9,519.1$ & $90,809.5$ \\
\hline 1,790 & $9,947.4$ & 100.542 .8 \\
\hline 1,791 & $10,374.7$ & $110,703.9$ \\
\hline 1,792 & $10,801.0$ & 121.291 .9 \\
\hline 1,793 & $11,226.2$ & $132,305.6$ \\
\hline 1,794 & $11,650.3$ & $143,743.9$ \\
\hline 1,795 & $12,073.3$ & $155,605.8$ \\
\hline 1,796 & $12,495.1$ & $167,890.1$ \\
\hline 1,797 & $12,915.6$ & $180,595.5$ \\
\hline 1,798 & $13,335.0$ & $193,720.9$ \\
\hline 1,799 & $13,753.2$ & 207.265 .1 \\
\hline 1,800 & $14,170.1$ & $221,226.9$ \\
\hline 1,801 & $14,585.8$ & $235,604.9$ \\
\hline 1,802 & $15,000.2$ & $250,398.0$ \\
\hline 1,803 & $15,413.4$ & $265,604.9$ \\
\hline 1,804 & $15,825.4$ & $281,224.3$ \\
\hline 1,805 & 16.236 .1 & $297,255.2$ \\
\hline 1,806 & $16,645.6$ & $313,696.1$ \\
\hline 1,807 & $17,053.8$ & $330,545.9$ \\
\hline 1,808 & $17,460.9$ & $347,803.3$ \\
\hline 1,809 & $17,866.6$ & $365,467.2$ \\
\hline 1,810 & $18,271.2$ & $383,536.2$ \\
\hline 1,811 & $18,674.5$ & $402,009.2$ \\
\hline 1,812 & $19,076.6$ & $420,884.8$ \\
\hline 1,813 & $19,477.3$ & $440,161.9$ \\
\hline 1,814 & $19,876.8$ & $459,839.0$ \\
\hline 1,815 & $20,275.0$ & $479,915.1$ \\
\hline
\end{tabular}


Table B6. Total inflow for water years 1961-98 for the Waubay Lakes Chain [Water year is October 1 through September 30]

\begin{tabular}{|c|c|c|c|c|c|c|c|c|}
\hline \multirow{2}{*}{$\begin{array}{l}\text { Water } \\
\text { year }\end{array}$} & \multicolumn{2}{|c|}{$\begin{array}{l}\text { Total inflow } \\
\text { (acre-feet) }\end{array}$} & \multirow{2}{*}{$\begin{array}{l}\text { Water } \\
\text { year }\end{array}$} & \multicolumn{2}{|c|}{$\begin{array}{l}\text { Total inflow } \\
\text { (acre-feet) }\end{array}$} & \multirow{2}{*}{$\begin{array}{l}\text { Water } \\
\text { year }\end{array}$} & \multicolumn{2}{|c|}{$\begin{array}{l}\text { Total inflow } \\
\text { (ع rre-feet) }\end{array}$} \\
\hline & Oct-Apr & May-Sept & & Oct-Apr & May-Sept & & Oct-Apr & May-Sept \\
\hline 1962 & $30,726.2$ & $-8,887.9$ & 1975 & $20,878.7$ & $1,039.8$ & 1988 & $10,657.3$ & $-1,791.9$ \\
\hline 1963 & $11,578.1$ & $7,679.6$ & 1976 & $37,018.2$ & $4,987.9$ & 1989 & $26,476.7$ & $1,663.3$ \\
\hline 1965 & $34,520.8$ & $1,391.8$ & 1978 & $27,124.2$ & $10,760.1$ & 1991 & $10,449.6$ & $13,794.8$ \\
\hline 1966 & $5,764.9$ & $14,368.2$ & 1979 & $30,041.2$ & $5,896.3$ & 1992 & $12,795.3$ & $5,964.4$ \\
\hline 1967 & $15,846.6$ & $2,347.2$ & 1980 & $7,404.1$ & $9,507.5$ & 1993 & $20,352.7$ & $35,507.8$ \\
\hline 1968 & $14,891.5$ & 807.0 & 1981 & $7,502.8$ & 165.7 & 1994 & $50,166.9$ & $13,140.5$ \\
\hline 1971 & $25,531.4$ & $8,709.3$ & 1984 & $17,504.9$ & $4,578.6$ & 1997 & $93,617.7$ & $14,206.2$ \\
\hline 1972 & $25,560.9$ & $9,145.2$ & 1985 & $16,676.2$ & $5,874.6$ & 1998 & $63,026.2$ & $23,199.4$ \\
\hline 1973 & $1,703.6$ & $2,875.4$ & 1986 & $31,624.3$ & $21,919.2$ & & & \\
\hline
\end{tabular}


Table B7. Simulated lake levels for the 10 major lakes of the Waubay Lakes Chain, 1963-98 [Lake levels in feet above sea level]

\begin{tabular}{|c|c|c|c|c|c|c|c|c|c|c|}
\hline Date & $\begin{array}{l}\text { Bitter } \\
\text { Lake }\end{array}$ & $\begin{array}{c}\text { Blue Dog } \\
\text { Lake }\end{array}$ & $\begin{array}{c}\text { Enemy } \\
\text { Swim } \\
\text { Lake }\end{array}$ & $\begin{array}{c}\text { Hille- } \\
\text { brands } \\
\text { Lake }\end{array}$ & $\begin{array}{l}\text { Minne- } \\
\text { wasta } \\
\text { Lake }\end{array}$ & $\begin{array}{c}\text { Pickerel } \\
\text { Lake }\end{array}$ & $\begin{array}{l}\text { Rush } \\
\text { Lake }\end{array}$ & $\begin{array}{l}\text { Spring } \\
\text { Lake }\end{array}$ & $\begin{array}{l}\text { Swan } \\
\text { Pond }\end{array}$ & $\begin{array}{l}\text { Wauhay } \\
\text { Lake }\end{array}$ \\
\hline $05-01-63$ & $1,771.5$ & $1,800.1$ & $1,851.0$ & $1,785.8$ & $1,797.3$ & $1,845.1$ & $1,798.9$ & $1,787.0$ & $1,785.4$ & $1,782.9$ \\
\hline $10-01-63$ & $1,771.6$ & $1,800.3$ & $1,851.2$ & $1,785.8$ & $1,797.4$ & $1,845.0$ & $1,798.6$ & $1,787.2$ & $1,785.4$ & $1,783.2$ \\
\hline $05-01-64$ & $1,771.7$ & $1,800.4$ & $1,851.3$ & $1,785.7$ & $1,797.5$ & $1,845.0$ & $1,798.5$ & $1,787.3$ & $1,785.4$ & $1,783.3$ \\
\hline $10-01-64$ & $1,771.5$ & $1,800.3$ & $1,851.1$ & $1,785.3$ & $1,797.1$ & $1,845.0$ & $1,798.3$ & $1,787.1$ & $1,785.0$ & $1,783.0$ \\
\hline $05-01-65$ & $1,772.8$ & $1,800.8$ & $1,852.7$ & $1,786.9$ & $1,797.7$ & $1,845.5$ & $1,799.0$ & $1,787.9$ & $1,785.0$ & $1,784.8$ \\
\hline $10-01-65$ & $1,772.8$ & $1,800.3$ & $1,852.6$ & $1,786.7$ & $1,797.8$ & $1,845.0$ & $1,798.7$ & $1,788.0$ & $1,785.8$ & $1,785.1$ \\
\hline $05-01-66$ & $1,772.8$ & $1,800.3$ & $1,852.6$ & $1,786.5$ & $1,797.8$ & $1,845.0$ & $1,798.5$ & 1.788 .0 & $1,786.7$ & $1,785.1$ \\
\hline $10-01-66$ & $1,772.4$ & $1,800.5$ & $1,852.4$ & $1,786.2$ & $1,797.4$ & $1,845.0$ & $1,798.3$ & $1,787.7$ & $1,786.1$ & $1,784.7$ \\
\hline $05-01-67$ & $1,772.9$ & $1,800.7$ & $1,853.0$ & $1,786.7$ & $1,797.6$ & $1,845.2$ & $1,798.7$ & $1,788.0$ & $1,786.7$ & $1,785.3$ \\
\hline $10-01-67$ & $1,771.8$ & $1,799.8$ & $1,851.9$ & $1,785.5$ & $1,796.7$ & $1,844.3$ & $1,797.6$ & $1,787.2$ & $1,785.8$ & $1,784.2$ \\
\hline $05-01-68$ & $1,772.3$ & $1,800.5$ & $1,852.5$ & $1,785.9$ & $1,796.9$ & $1,845.0$ & $1,798.3$ & $1,787.6$ & $1,785.8$ & $1,784.5$ \\
\hline $10-01-68$ & $1,771.4$ & $1,799.8$ & $1,851.7$ & $1,784.9$ & $1,796.3$ & $1,844.3$ & $1,797.5$ & $1,787.1$ & $1,785.3$ & $1,783.7$ \\
\hline 05-01-69 & $1,772.9$ & $1,800.3$ & $1,853.3$ & $1,786.6$ & $1,797.2$ & $1,845.4$ & $1,798.9$ & $1,788.0$ & $1,785.8$ & $1,785.4$ \\
\hline $10-01-69$ & $1,771.8$ & $1,799.0$ & $1,852.3$ & $1,785.3$ & $1,796.4$ & $1,844.2$ & $1,798.0$ & $1,787.4$ & $1,785.2$ & $1,784.4$ \\
\hline $05-01-70$ & $1,772.5$ & $1,800.4$ & $1,853.0$ & $1,786.0$ & $1,796.9$ & $1,845.1$ & $1,798.5$ & $1,787.9$ & $1,785.4$ & $1,785.0$ \\
\hline $10-01-70$ & $1,771.0$ & $1,798.7$ & $1,851.6$ & $1,784.3$ & $1,795.8$ & $1,843.5$ & $1,797.1$ & $1,787.0$ & $1,784.5$ & $1,783.7$ \\
\hline $05-01-71$ & $1,772.1$ & 1.800 .6 & $1,852.7$ & $1,785.5$ & $1,796.3$ & $1,845.1$ & $1,798.3$ & $1,787.6$ & $1,784.6$ & $1,784.3$ \\
\hline $10-01-71$ & $1,771.7$ & $1,800.3$ & $1,852.3$ & $1,785.0$ & $1,795.8$ & $1,845.0$ & $1,798.1$ & $1,787.2$ & $1,784.1$ & $1,783.8$ \\
\hline $05-01-72$ & $1,773.0$ & $1,800.7$ & $1,853.6$ & $1,786.4$ & $1,796.7$ & $1,845.4$ & $1,799.0$ & $1,788.0$ & $1,785.6$ & $1,785.6$ \\
\hline $10-01-72$ & $1,773.1$ & $1,800.6$ & $1,853.6$ & $1,786.5$ & $1,796.8$ & $1,845.1$ & $1,798.8$ & $1,788.1$ & $1,787.1$ & $1,78 \varsigma .0$ \\
\hline $05-01-73$ & $1,772.8$ & $1,800.2$ & $1,853.4$ & $1,786.1$ & $1,796.7$ & $1,844.9$ & $1,798.4$ & $1,788.0$ & $1,787.8$ & $1,785.9$ \\
\hline $10-01-73$ & $1,771.8$ & $1,799.4$ & $1,852.3$ & $1,784.8$ & $1,795.8$ & $1,844.1$ & $1,797.3$ & $1,787.2$ & $1,786.9$ & $1,784.8$ \\
\hline $05-01-74$ & $1,772.7$ & $1,800.7$ & $1,853.4$ & $1,785.9$ & $1,796.2$ & $1,845.2$ & $1,798.5$ & $1,787.7$ & $1,786.7$ & $1,785.4$ \\
\hline $10-01-74$ & $1,771.0$ & $1,799.1$ & $1,851.9$ & $1,784.2$ & $1,795.0$ & $1,843.6$ & $1,797.1$ & $1,786.6$ & $1,785.7$ & $1,784.0$ \\
\hline $05-01-75$ & $1,771.9$ & $1,800.6$ & $1,852.7$ & $1,785.0$ & $1,795.4$ & $1,845.0$ & $1,798.1$ & $1,787.1$ & $1,785.6$ & $1,784.4$ \\
\hline $10-01-75$ & $1,770.7$ & $1,799.6$ & $1,851.6$ & $1,783.8$ & $1,794.5$ & $1,844.1$ & $1,797.0$ & $1,786.3$ & $1,784.8$ & $1,783.3$ \\
\hline $05-01-76$ & $1,772.4$ & $1,800.9$ & $1,853.2$ & $1,785.4$ & $1,795.2$ & $1,845.4$ & $1,798.7$ & $1,787.0$ & $1,784.7$ & $1,784.5$ \\
\hline $10-01-76$ & $1,769.2$ & $1,799.2$ & $1,851.0$ & $1,783.1$ & $1,793.0$ & $1,843.5$ & $1,796.2$ & $1,785.0$ & $1,782.2$ & $1,782.1$ \\
\hline $05-01-77$ & $1,769.2$ & $1,797.2$ & $1,849.9$ & $1,781.8$ & $1,792.6$ & $1,841.9$ & $1,795.7$ & $1,784.8$ & $1,782.5$ & $1,781.5$ \\
\hline $10-01-77$ & $1,771.0$ & $1,799.0$ & $1,850.1$ & $1,781.9$ & $1,792.5$ & $1,843.1$ & $1,795.2$ & $1,784.6$ & $1,782.0$ & $1,781.2$ \\
\hline $05-01-78$ & $1,772.3$ & $1,800.7$ & $1,851.6$ & $1,783.4$ & $1,793.4$ & $1,845.1$ & $1,797.3$ & $1,785.5$ & $1,782.4$ & $1,782.1$ \\
\hline $10-01-78$ & $1,772.3$ & $1,800.5$ & $1,851.6$ & $1,783.3$ & 1.793 .3 & $1,845.0$ & $1,797.7$ & $1,785.4$ & $1,782.3$ & $1,782.0$ \\
\hline 05-01-79 & $1,773.4$ & $1,800.4$ & $1,853.0$ & $1,784.8$ & $1,794.1$ & $1,845.5$ & $1,799.0$ & $1,786.2$ & $1,782.6$ & $1,783.8$ \\
\hline $10-01-79$ & $1,772.8$ & $1,800.1$ & $1,852.5$ & $1,784.1$ & $1,793.7$ & $1,845.0$ & $1,798.3$ & $1,785.9$ & $1,782.2$ & $1,783.2$ \\
\hline $05-01-80$ & $1,772.8$ & $1,800.3$ & $1,852.5$ & $1,784.0$ & $1,793.7$ & $1,845.0$ & $1,798.3$ & $1,786.0$ & $1,782.3$ & $1,783.2$ \\
\hline $10-01-80$ & $1,772.2$ & $1,800.2$ & $1,852.0$ & $1,783.4$ & $1,793.2$ & $1,844.9$ & $1,797.8$ & $1,785.5$ & $1,781.8$ & $1,782.5$ \\
\hline $05-01-81$ & $1,772.2$ & $1,800.3$ & $1,852.0$ & $1,783.3$ & $1,793.3$ & $1,845.0$ & $1,798.0$ & $1,785.6$ & $1,782.0$ & $1,782.5$ \\
\hline
\end{tabular}


Table B7. Simulated lake levels for the 10 major lakes of the Waubay Lakes Chain, 1963-98-Continued [Lake levels in feet above sea level]

\begin{tabular}{|c|c|c|c|c|c|c|c|c|c|c|}
\hline Date & $\begin{array}{l}\text { Bitter } \\
\text { Lake }\end{array}$ & $\begin{array}{l}\text { Blue Dog } \\
\text { Lake }\end{array}$ & $\begin{array}{l}\text { Enemy } \\
\text { Swim } \\
\text { Lake }\end{array}$ & $\begin{array}{c}\text { Hille- } \\
\text { brands } \\
\text { Lake }\end{array}$ & $\begin{array}{c}\text { Minne- } \\
\text { wasta } \\
\text { Lake }\end{array}$ & $\begin{array}{l}\text { Pickerel } \\
\text { Lake }\end{array}$ & $\begin{array}{l}\text { Rush } \\
\text { Lake }\end{array}$ & $\begin{array}{c}\text { Spring } \\
\text { Lake }\end{array}$ & $\begin{array}{l}\text { Swan } \\
\text { Prnd }\end{array}$ & $\begin{array}{c}\text { Waubay } \\
\text { Lake }\end{array}$ \\
\hline $10-01-81$ & $1,771.1$ & $1,799.3$ & $1,851.0$ & $1,782.1$ & $1,792.5$ & $1,844.0$ & $1,797.0$ & $1,785.0$ & $1,7 \varepsilon 1.5$ & $1,781.4$ \\
\hline $05-01-82$ & $1,772.0$ & $1,800.6$ & $1,852.0$ & $1,783.0$ & $1,793.1$ & $1,845.1$ & $1,798.2$ & $1,785.6$ & $1,7 \varepsilon 2.0$ & $1,782.1$ \\
\hline $10-01-82$ & $1,771.2$ & $1,799.6$ & $1,851.1$ & $1,782.0$ & $1,792.7$ & $1,844.2$ & 1.797 .5 & $1,785.2$ & $1,7 \varepsilon 1.9$ & $1,781.4$ \\
\hline $10-01-83$ & $1,770.6$ & $1,799.1$ & $1,850.6$ & $1,781.2$ & $1,792.4$ & $1,843.9$ & $1,797.2$ & $1,785.1$ & $1,7 \varepsilon 2.0$ & $1,780.8$ \\
\hline $05-01-84$ & $1,771.6$ & $1,800.5$ & $1,851.5$ & $1,782.0$ & $1,793.1$ & $1,845.0$ & $1,798.1$ & $1,785.7$ & $1,7 \varepsilon 2.4$ & $1,781.4$ \\
\hline $10-01-84$ & $1,771.1$ & $1,800.1$ & $1,851.0$ & $1,781.3$ & $1,792.7$ & $1,844.8$ & $1,797.7$ & $1,785.4$ & $1.7 \varepsilon 2.1$ & $1,780.8$ \\
\hline $05-01-85$ & $1,771.8$ & $1,800.6$ & $1,851.7$ & $1,782.0$ & $1,793.2$ & $1,845.2$ & $1,798.5$ & $1,785.9$ & $1,7 \varepsilon 2.4$ & $1,781.5$ \\
\hline $05-01-87$ & $1,774.7$ & $1,801.9$ & $1,854.0$ & $1,786.1$ & $1,795.8$ & $1,845.5$ & $1,799.2$ & $1,788.0$ & $1,7 \varepsilon .4 .3$ & $1,787.3$ \\
\hline $10-01-87$ & $1,773.4$ & $1,800.1$ & $1,852.5$ & $1,784.4$ & $1,794.7$ & $1,844.0$ & $1,798.0$ & $1,787.1$ & $1,7 £ 3.4$ & $1,786.1$ \\
\hline $05-01-88$ & $1,773.2$ & $1,800.3$ & $1,852.4$ & $1,784.2$ & $1,794.5$ & $1,844.5$ & $1,798.0$ & $1,787.0$ & $1,7 \varepsilon 3.1$ & $1,785.7$ \\
\hline $10-01-88$ & $1,771.9$ & $1,798.9$ & $1,851.1$ & $1,782.7$ & $1,793.5$ & $1,843.2$ & $1,796.8$ & $1,786.1$ & $1,7 £ 2.3$ & $1,784.5$ \\
\hline $05-01-89$ & 1.772 .9 & $1,800.7$ & $1,852.4$ & $1,784.0$ & $1,794.2$ & $1,845.1$ & $1,798.3$ & $1,786.8$ & $1,7 \varepsilon 2.5$ & $1,785.1$ \\
\hline $10-01-89$ & $1,772.0$ & $1,799.9$ & $1,851.5$ & $1,783.0$ & $1,793.5$ & $1,844.3$ & $1,797.4$ & $1,786.2$ & $1,7 \varepsilon 2.0$ & $1,784.2$ \\
\hline $05-01-90$ & $1,772.2$ & $1,800.4$ & $1,851.8$ & $1,783.1$ & $1,793.7$ & $1,845.0$ & $1,797.8$ & $1,786.4$ & $1,7 \varepsilon 2.2$ & $1,784.2$ \\
\hline $05-01-93$ & $1,772.9$ & $1,800.7$ & $1,852.9$ & $1,783.7$ & $1,794.4$ & $1,845.3$ & $1,798.8$ & $1,787.4$ & $1,7 \varepsilon 2.7$ & $1,785.1$ \\
\hline $10-01-93$ & $1,774.4$ & $1,802.1$ & $1,853.9$ & $1,785.8$ & $1,795.7$ & $1,845.6$ & $1,799.2$ & $1,788.1$ & $1,7 £ 5.3$ & $1,787.6$ \\
\hline $05-01-94$ & $1,778.1$ & $1,800.6$ & $1,854.4$ & $1,788.1$ & $1,798.0$ & $1,845.8$ & $1,800.6$ & $1,789.0$ & $1,7 \varepsilon 9.0$ & $1,790.7$ \\
\hline $10-01-94$ & $1,778.4$ & $1,800.3$ & $1,853.7$ & $1,787.8$ & $1,797.9$ & $1,845.1$ & $1,799.3$ & $1,788.9$ & $1,7 \& 8.9$ & $1,791.0$ \\
\hline $05-01-95$ & $1,781.3$ & $1,800.2$ & $1,854.2$ & $1,793.1$ & $1,800.2$ & $1,845.6$ & $1,800.2$ & $1,790.0$ & $1,709.0$ & $1,793.1$ \\
\hline $10-01-95$ & $1,782.1$ & $1,800.4$ & $1,853.9$ & $1,794.0$ & $1,799.8$ & $1,845.2$ & $1,799.8$ & $1,790.3$ & $1,709.3$ & $1,794.0$ \\
\hline $05-01-96$ & $1,784.5$ & $1,800.5$ & $1,854.3$ & $1,796.0$ & $1,800.5$ & $1,845.7$ & $1,800.5$ & $1,791.1$ & $1,701.1$ & $1,796.0$ \\
\hline $10-01-96$ & $1,784.2$ & $1,800.1$ & $1,853.6$ & $1,796.0$ & $1,799.4$ & $1,845.0$ & $1,799.4$ & $1,791.0$ & $1,701.0$ & $1,796.0$ \\
\hline $05-01-97$ & $1,788.5$ & $1,799.9$ & $1,855.2$ & $1,799.8$ & $1,799.9$ & $1,846.4$ & $1,799.9$ & $1,799.8$ & $1,709.8$ & $1,799.9$ \\
\hline $10-01-97$ & $1,788.2$ & $1,800.4$ & $1,854.0$ & $1,799.5$ & $1,799.5$ & $1,845.2$ & $1,799.5$ & $1,799.5$ & $1,709.5$ & $1,799.5$ \\
\hline $05-01-98$ & $1,790.6$ & $1,801.8$ & $1,854.8$ & $1,801.8$ & $1,801.8$ & $1,846.0$ & $1,801.8$ & $1,801.8$ & $1,801.8$ & $1,801.8$ \\
\hline $10-01-98$ & $1,790.7$ & $1,801.9$ & $1,854.0$ & $1,801.9$ & $1,801.9$ & $1,845.3$ & $1,801.9$ & $1,801.9$ & $1,801.9$ & $1,801.9$ \\
\hline
\end{tabular}


Table B8. Simulated lake areas, in acres, for the 10 major lakes of the Waubay Lakes Chain, 1963-98

\begin{tabular}{|c|c|c|c|c|c|c|c|c|c|c|}
\hline Date & $\begin{array}{l}\text { Bitter } \\
\text { Lake }\end{array}$ & $\begin{array}{l}\text { Blue Dog } \\
\text { Lake }\end{array}$ & $\begin{array}{l}\text { Enemy } \\
\text { Swim } \\
\text { Lake }\end{array}$ & $\begin{array}{l}\text { Hille- } \\
\text { brands } \\
\text { Lake }\end{array}$ & $\begin{array}{l}\text { Minne- } \\
\text { wasta } \\
\text { Lake }\end{array}$ & $\begin{array}{l}\text { Pickerel } \\
\text { Lake }\end{array}$ & $\begin{array}{l}\text { Rush } \\
\text { Lake }\end{array}$ & $\begin{array}{c}\text { Spring } \\
\text { Lake }\end{array}$ & $\begin{array}{l}\text { Swan } \\
\text { Pond }\end{array}$ & $\begin{array}{c}\text { Waubay } \\
\text { Lal'? }\end{array}$ \\
\hline $05-01-63$ & $2,499.4$ & $1,602.9$ & $2,535.5$ & 550.8 & 968.7 & 969.5 & $3,011.6$ & 937.1 & 104 & $6,864.9$ \\
\hline $10-01-63$ & $2,585.4$ & $1,612.4$ & $2,550.2$ & 550.3 & 971.9 & 967.2 & $2,951.1$ & 941.5 & 104.1 & $6,984.4$ \\
\hline $05-01-64$ & $2,656.0$ & $1,615.0$ & $2,564.0$ & 549.6 & 975.0 & 966.7 & $2,935.7$ & 945.9 & 104.3 & $7,068.3$ \\
\hline $10-01-64$ & $2,508.9$ & $1,613.3$ & $2,539.5$ & 543.5 & 957.4 & 965.1 & $2,890.1$ & 940.9 & 101.0 & $6,909.3$ \\
\hline $05-01-65$ & $3,166.1$ & $1,635.8$ & $2,725.7$ & 570.1 & 989.5 & 983.6 & $3,045.2$ & 958.3 & 101.1 & $7,728.1$ \\
\hline $10-01-65$ & $3,152.0$ & $1,612.3$ & $2,717.5$ & 565.9 & 994.7 & 966.6 & $2,965.1$ & 962.2 & 106.6 & $7,841.3$ \\
\hline $05-01-66$ & $3,137.6$ & $1,610.9$ & $2,715.4$ & 563.0 & 995.1 & 965.3 & $2,928.5$ & 962.8 & 112.9 & $7,857.0$ \\
\hline $10-01-66$ & $3,015.1$ & $1,619.1$ & $2,696.1$ & 558.4 & 971.1 & 967.0 & $2,894.5$ & 954.8 & 108.6 & $7,667.0$ \\
\hline $05-01-67$ & 3.190 .9 & $1,628.4$ & $2,763.8$ & 566.7 & 984.7 & 972.3 & $2,971.8$ & 962.4 & 112.8 & $7,942.4$ \\
\hline $10-01-67$ & $2,686.3$ & $1,590.6$ & $2,638.6$ & 545.6 & 936.4 & 940.6 & $2,732.2$ & 943.2 & 107.0 & $7,45 \varepsilon .7$ \\
\hline $05-01-68$ & $2,929.2$ & $1,622.3$ & $2,701.3$ & 553.0 & 948.9 & 967.2 & $2,887.4$ & 951.6 & 107.1 & $7,573.9$ \\
\hline $10-01-68$ & $2,486.9$ & 1.591 .2 & $2,609.0$ & 536.6 & 918.0 & 942.8 & $2,720.8$ & 940.3 & 103.4 & $7,231.7$ \\
\hline $05-01-69$ & $3,183.2$ & $1,611.5$ & $2,799.2$ & 564.5 & 960.6 & 979.3 & $3,021.3$ & 961.9 & 106.9 & $7,965.8$ \\
\hline $10-01-69$ & $2,711.7$ & $1,551.9$ & $2,674.5$ & 543.0 & 920.6 & 939.4 & $2,817.6$ & 946.4 & 102.4 & $7,542.0$ \\
\hline $05-01-70$ & $3,038.6$ & $1,616.6$ & $2,762.1$ & 554.3 & 945.1 & 968.4 & $2,922.0$ & 960.2 & 104.3 & $7,795.6$ \\
\hline $10-01-70$ & $2,158.4$ & $1,533.7$ & $2,595.8$ & 526.8 & 888.3 & 914.2 & $2,643.4$ & 937.3 & 96.6 & $7,221.9$ \\
\hline $05-01-71$ & $2,872.1$ & $1,626.6$ & $2,729.1$ & 545.9 & 914.9 & 969.8 & $2,894.4$ & 951.3 & 97.2 & $7,505.3$ \\
\hline $10-01-71$ & $2,647.1$ & $1,614.1$ & $2,684.4$ & 537.3 & 892.1 & 964.6 & $2,845.9$ & 943.4 & 91.9 & $7,265.9$ \\
\hline $05-01-72$ & $3,213.0$ & $1,628.8$ & $2,828.7$ & 561.6 & 936.4 & 980.3 & $3,039.4$ & 962.8 & 105.4 & $8,047.4$ \\
\hline $10-01-72$ & $3,243.4$ & $1,624.1$ & $2,827.9$ & 562.2 & 940.9 & 969.9 & $2,986.2$ & 963.4 & 115.0 & $8,220.0$ \\
\hline $05-01-73$ & $3,172.6$ & $1,605.9$ & $2,800.8$ & 555.3 & 938.0 & 963.3 & $2,921.4$ & 962.5 & 119.2 & $8,165.7$ \\
\hline $10-01-73$ & $2,672.6$ & 1.571 .7 & $2,679.2$ & 535.0 & 890.5 & 934.2 & $2,681.9$ & 943.6 & 113.8 & $7,689.4$ \\
\hline $05-01-74$ & $3,101.1$ & $1,631.8$ & $2,802.1$ & 553.1 & 911.8 & 973.3 & $2,931.5$ & 955.1 & 113.0 & $7,971.9$ \\
\hline $10-01-74$ & $2,210.5$ & $1,555.7$ & $2,627.6$ & 524.6 & 848.3 & 919.3 & $2,625.4$ & 929.6 & 105.8 & $7,350.9$ \\
\hline $05-01-75$ & $2,764.7$ & $1,623.7$ & $2,724.5$ & 538.1 & 869.0 & 967.3 & $2,838.2$ & 940.2 & 105.7 & $7,515.5$ \\
\hline $10-01-75$ & $1,968.6$ & $1,580.6$ & $2,600.0$ & 517.0 & 823.4 & 933.4 & $2,604.4$ & 922.8 & 99.5 & $7,046.4$ \\
\hline $05-01-76$ & $2,976.5$ & $1,637.9$ & $2,780.6$ & 545.0 & 856.5 & 979.1 & $2,971.7$ & 937.5 & 98.0 & $7,571.3$ \\
\hline $10-01-76$ & 0 & $1,561.2$ & $2,525.1$ & 505.8 & 738.8 & 914.4 & $2,429.4$ & 892.0 & 61.4 & $6,520.2$ \\
\hline $05-01-77$ & 0 & $1,437.7$ & 2.411 .7 & 483.8 & 720.2 & 860.1 & $2,283.7$ & 887.8 & 66.7 & $6,237.0$ \\
\hline $10-01-77$ & $2,187.6$ & $1,552.4$ & $2,428.4$ & 485.1 & 711.3 & 900.5 & $2,138.9$ & 884.1 & 56.0 & $6,098.0$ \\
\hline 05-01-78 & $2,973.0$ & $1,631.5$ & $2,598.2$ & 510.7 & 760.9 & 969.5 & $2,683.0$ & 902.8 & 65.5 & $6,533.0$ \\
\hline $10-01-78$ & $2,929.5$ & 1.621 .4 & 2,596.6 & 508.7 & 757.1 & 967.2 & $2,763.7$ & 902.2 & 62.9 & $6,467.7$ \\
\hline 05-01-79 & $3,334.4$ & $1,616.7$ & $2,762.9$ & 534.0 & 800.9 & 981.8 & $3,027.1$ & 919.8 & 68.9 & $7,253.6$ \\
\hline $10-01-79$ & $3,158.3$ & $1,605.5$ & $2,705.1$ & 523.4 & 778.4 & 965.1 & $2,899.9$ & 912.1 & 61.0 & $7,027.6$ \\
\hline 05-01-80 & $3,139.9$ & $1,611.2$ & $2,704.6$ & 521.2 & 780.8 & 965.7 & $2,898.6$ & 914.5 & 63.9 & $7,010.7$ \\
\hline $10-01-80$ & $2,894.1$ & $1,608.9$ & $2,648.1$ & 511.2 & 752.5 & 963.5 & $2,789.9$ & 904.2 & 50.2 & $6,705.6$ \\
\hline $05-01-81$ & $2,890.2$ & $1,612.8$ & $2,650.2$ & 509.4 & 756.3 & 965.5 & $2,828.9$ & 906.8 & 56.0 & $6,676.3$ \\
\hline $10-01-81$ & $2,237.0$ & $1,567.6$ & $2,531.1$ & 488.4 & 712.9 & 931.9 & $2,610.4$ & 891.7 & 42.7 & $6,218.7$ \\
\hline
\end{tabular}


Table B8. Simulated lake areas, in acres, for the 10 major lakes of the Waubay Lakes Chain, 1963-98-Continued

\begin{tabular}{|c|c|c|c|c|c|c|c|c|c|c|}
\hline Date & $\begin{array}{l}\text { Bitter } \\
\text { Lake }\end{array}$ & $\begin{array}{l}\text { Blue Dog } \\
\text { Lake }\end{array}$ & $\begin{array}{l}\text { Enemy } \\
\text { Swim } \\
\text { Lake }\end{array}$ & $\begin{array}{c}\text { Hille- } \\
\text { brands } \\
\text { Lake }\end{array}$ & $\begin{array}{c}\text { Minne- } \\
\text { wasta } \\
\text { Lake }\end{array}$ & $\begin{array}{l}\text { Pickerel } \\
\text { Lake }\end{array}$ & $\begin{array}{l}\text { Rush } \\
\text { Lake }\end{array}$ & $\begin{array}{l}\text { Spring } \\
\text { Lake }\end{array}$ & $\begin{array}{l}S \text { van } \\
P \sim n d\end{array}$ & $\begin{array}{c}\text { Waubay } \\
\text { Lake }\end{array}$ \\
\hline $05-01-82$ & $2,803.4$ & $1,625.4$ & $2,639.0$ & 504.4 & 747.5 & 969.5 & $2,863.0$ & 904.9 & 54.9 & $6,503.8$ \\
\hline $10-01-82$ & $2,320.5$ & $1,581.9$ & $2,546.0$ & 486.7 & 721.3 & 939.3 & $2,716.6$ & 896.6 & 52.8 & $6,178.3$ \\
\hline $05-01-83$ & $2,632.4$ & $1,614.8$ & $2,599.7$ & 493.1 & 745.0 & 965.0 & $2,838.2$ & 906.6 & 63.0 & $6,317.2$ \\
\hline $10-01-83$ & 1.842 .5 & 1.557 .3 & $2,483.4$ & 472.1 & 708.2 & 926.8 & $2,650.9$ & 894.3 & 55.0 & $5,894.2$ \\
\hline $05-01-84$ & $2,574.6$ & $1,620.9$ & $2,585.6$ & 486.7 & 743.7 & 967.5 & $2,857.9$ & 908.0 & 64.7 & $6,182.8$ \\
\hline $10-01-84$ & $2,214.3$ & $1,604.2$ & 2.525 .7 & 475.2 & 721.8 & 959.1 & $2,757.2$ & 900.6 & 58.1 & $5,905.1$ \\
\hline $05-01-85$ & $2,694.8$ & $1,627.4$ & $2,609.7$ & 487.3 & 749.7 & 971.8 & $2,929.0$ & 911.6 & 65.1 & $6,249.1$ \\
\hline $10-01-85$ & $2,428.6$ & $1,610.2$ & $2,561.3$ & 477.8 & 731.3 & 963.8 & $2,866.8$ & 905.4 & 59.1 & $6,018.4$ \\
\hline 05-01-86 & $3,223.4$ & $1,643.7$ & $2,780.5$ & 512.9 & 802.8 & 984.4 & $3,051.4$ & 932.7 & 72.9 & $7,174.3$ \\
\hline $10-01-86$ & $3,476.7$ & $1,661.0$ & $2,845.6$ & 533.3 & 851.0 & 981.0 & $3,064.1$ & 951.9 & 80.7 & $8,026.4$ \\
\hline $05-01-87$ & $3,623.8$ & $1,682.7$ & $2,870.8$ & 555.7 & 887.5 & 984.0 & $3,078.3$ & 962.7 & 94.5 & $8,807.0$ \\
\hline $10-01-87$ & $3,344.5$ & $1,602.0$ & $2,707.3$ & 528.5 & 830.6 & 930.9 & $2,835.7$ & 940.0 & 83.3 & $8,252.2$ \\
\hline $05-01-88$ & $3,280.7$ & $1,613.2$ & $2,695.8$ & 525.2 & 820.9 & 949.9 & $2,828.8$ & 937.2 & 78.7 & $8,087.8$ \\
\hline $10-01-88$ & $2,736.3$ & $1,544.2$ & $2,544.4$ & 499.6 & 766.6 & 903.0 & $2,562.1$ & 916.7 & 61.9 & $7,556.6$ \\
\hline $05-01-89$ & $3,183.9$ & $1,629.2$ & $2,690.9$ & 521.7 & 804.3 & 968.8 & $2,883.8$ & 932.3 & 67.8 & $7,834.7$ \\
\hline $10-01-89$ & $2,801.3$ & $1,595.3$ & $2,589.4$ & 503.9 & 767.8 & 943.1 & $2,700.7$ & 918.9 & 56.0 & $7,447.2$ \\
\hline $05-01-90$ & $2,896.0$ & $1,617.0$ & $2,619.3$ & 506.7 & 776.3 & 964.8 & $2,789.2$ & 923.2 & 59.7 & $7,444.5$ \\
\hline $10-01-90$ & $2,515.5$ & $1,591.3$ & $2,539.6$ & 491.6 & 751.2 & 944.4 & $2,642.4$ & 914.7 & 54.8 & $7,146.2$ \\
\hline $05-01-91$ & $2,732.3$ & $1,616.0$ & $2,584.1$ & 496.5 & 769.1 & 965.3 & $2,762.2$ & 922.9 & 63.0 & $7,223.8$ \\
\hline $10-01-91$ & $2,998.6$ & $1,626.9$ & 2.657 .4 & 506.3 & 794.4 & 971.5 & $2,930.2$ & 934.3 & 70.4 & $7,477.2$ \\
\hline $05-01-92$ & $3,078.1$ & $1,625.2$ & $2,690.9$ & 510.0 & 802.9 & 970.2 & $2,957.6$ & 938.8 & 71.4 & $7,625.1$ \\
\hline $10-01-92$ & $2,887.9$ & $1,609.9$ & $2,644.7$ & 500.9 & 785.4 & 963.7 & $2,886.7$ & 932.9 & 65.7 & $7,413.5$ \\
\hline $05-01-93$ & $3,191.9$ & $1,631.8$ & $2,750.6$ & 516.6 & 815.5 & 975.1 & $2,992.9$ & 946.2 & 71.6 & $7,849.1$ \\
\hline $10-01-93$ & $3,564.3$ & $1,689.9$ & $2,864.6$ & 551.2 & 883.5 & 988.2 & $3,082.5$ & 964.9 & 110.1 & $8,924.1$ \\
\hline $05-01-94$ & $3,974.9$ & $1,623.8$ & $2,923.4$ & 589.9 & $1,001.1$ & 994.1 & $3,362.3$ & 986.6 & 126.6 & $10,243.2$ \\
\hline $10-01-94$ & $4,003.8$ & $1,611.3$ & $2,843.1$ & 585.5 & 998.4 & 971.2 & $3,098.1$ & 982.3 & 125.5 & $10,372.1$ \\
\hline $05-01-95$ & $4,489.9$ & $1,605.9$ & $2,903.2$ & 684.9 & $1,112.8$ & 987.2 & $3,278.8$ & $1,009.5$ & 132.0 & $11,283.2$ \\
\hline $10-01-95$ & $4,698.0$ & $1,616.8$ & $2,861.2$ & 702.4 & $1,094.5$ & 974.6 & $3,203.6$ & $1,018.2$ & 134.0 & $11,650.4$ \\
\hline 05-01-96 & $5,528.0$ & $1,623.0$ & $2,906.5$ & 743.3 & $1,132.3$ & 989.2 & $3,358.3$ & $1,037.6$ & 138.6 & $12,474.9$ \\
\hline $10-01-96$ & $5,386.7$ & $1,602.4$ & $2,830.4$ & 743.4 & $1,074.6$ & 965.0 & $3,122.1$ & $1,035.7$ & 138.1 & $12,477.8$ \\
\hline 05-01-97 & $7,476.3$ & $1,592.4$ & $3,015.5$ & 829.9 & $1,097.6$ & $1,014.2$ & $3,216.6$ & $1,250.9$ & 187.1 & $14,110.0$ \\
\hline $10-01-97$ & $7,311.5$ & $1,614.6$ & $2,871.2$ & 822.6 & $1,081.0$ & 974.2 & $3,148.6$ & $1,243.4$ & 185.4 & $13,974.6$ \\
\hline $05-01-98$ & $8,805.4$ & $1,674.8$ & $2,966.2$ & 875.0 & $1,194.3$ & 999.9 & $3,608.8$ & $1,295.4$ & 197.1 & $14,900.3$ \\
\hline $10-01-98$ & $8,881.9$ & $1,679.9$ & $2,878.4$ & 877.6 & $1,200.4$ & 977.9 & $3,633.1$ & $1,297.9$ & 197.6 & $14,949.6$ \\
\hline
\end{tabular}


Table B9. Simulated lake volumes, in acre-feet, for the 10 major lakes of the Waubay Lakes Chain, 1963-98

\begin{tabular}{|c|c|c|c|c|c|c|c|c|c|c|}
\hline Date & $\begin{array}{l}\text { Bitter } \\
\text { Lake }\end{array}$ & $\begin{array}{c}\text { Blue Dog } \\
\text { Lake }\end{array}$ & $\begin{array}{l}\text { Enemy } \\
\text { Swim } \\
\text { Lake }\end{array}$ & $\begin{array}{c}\text { Hille- } \\
\text { brands } \\
\text { Lake }\end{array}$ & $\begin{array}{l}\text { Minne- } \\
\text { wasta } \\
\text { Lake }\end{array}$ & $\begin{array}{c}\text { Plckerel } \\
\text { Lake }\end{array}$ & $\begin{array}{l}\text { Rush } \\
\text { Lake }\end{array}$ & $\begin{array}{l}\text { Spring } \\
\text { Lake }\end{array}$ & $\begin{array}{l}\text { Swan } \\
\text { Pond }\end{array}$ & $\begin{array}{l}\text { Wa'bay } \\
\text { Lake }\end{array}$ \\
\hline $05-01-63$ & $3,366.8$ & $10,382.9$ & $31,606.2$ & $5,649.5$ & $7,468.1$ & $15,585.9$ & $12,890.5$ & $7,542.3$ & 344.1 & $40,638.9$ \\
\hline $10-01-63$ & $3,719.0$ & $10,720.3$ & $31,936.5$ & $5,631.5$ & $7,529.4$ & $15,520.7$ & $12,032.4$ & $7,722.1$ & 345.9 & $42,507.3$ \\
\hline $05-01-64$ & $4,033.2$ & $10,812.5$ & $32,246.3$ & $5,609.8$ & $7,587.5$ & $15,507.4$ & $11,817.0$ & $7,898.5$ & 347.7 & $43, \varepsilon 41.7$ \\
\hline $10-01-64$ & $3,404.2$ & $10,751.8$ & $31,695.7$ & $5,407.9$ & $7,255.8$ & $15,462.8$ & $11,186.5$ & $7,697.2$ & 304.2 & $41,328.3$ \\
\hline $05-01-65$ & $7,281.2$ & $11,585.5$ & $35,977.7$ & $6,288.3$ & $7,865.7$ & $15,981.2$ & $13,375.0$ & $8,393.4$ & 305.2 & $54,596.9$ \\
\hline $10-01-65$ & $7,158.7$ & $10,716.0$ & $35,784.0$ & $6,149.5$ & $7,967.9$ & $15,504.1$ & $12,228.8$ & $8,551.7$ & 382.4 & $57, C 24.3$ \\
\hline $05-01-66$ & $7,035.7$ & $10,665.6$ & $35,735.6$ & $6,053.0$ & $7,974.4$ & $15,467.5$ & $11,716.5$ & $8,572.3$ & 487.9 & $57,307.9$ \\
\hline $10-01-66$ & $6,088.8$ & $10,962.9$ & $35,280.3$ & $5,899.1$ & $7,514.1$ & $15,516.3$ & $11,247.2$ & $8,252.0$ & 413.1 & $53, \subseteq 17.1$ \\
\hline $05-01-67$ & $7,503.8$ & $11,307.4$ & $36,887.7$ & $6,176.4$ & $7,773.7$ & $15,663.0$ & 12323.5 & $8,556.7$ & 486.4 & $58, \varepsilon 62.7$ \\
\hline $10-01-67$ & $4,175.6$ & $9,958.8$ & $33,943.6$ & $5,477.4$ & $6,870.3$ & $14,785.9$ & $9,094.9$ & $7,788.7$ & 388.5 & $50,203.9$ \\
\hline $05-01-68$ & $5,512.6$ & $11,081.5$ & $35,402.0$ & $5,722.4$ & $7,099.3$ & $15,521.0$ & $11,149.7$ & $8,125.9$ & 390.4 & $52,2.87 .1$ \\
\hline $10-01-68$ & $3,318.4$ & $9,978.4$ & $33,265.7$ & $5,185.4$ & $6,538.8$ & $14,846.7$ & $8,949.2$ & $7,673.3$ & 336.0 & $46,496.6$ \\
\hline 05-01-69 & $7,434.5$ & $10,686.6$ & $37,740.7$ & $6,101.1$ & $7,315.4$ & $15,859.0$ & $13,030.1$ & $8,537.0$ & 387.1 & $59,2.92 .2$ \\
\hline $10-01-69$ & $4,298.6$ & $8,719.0$ & $34,775.5$ & $5,391.9$ & $6,585.3$ & $14,752.4$ & $10,207.8$ & $7,915.7$ & 321.9 & $51,734.9$ \\
\hline $05-01-70$ & $6,258.3$ & $10,872.7$ & $36,847.1$ & $5,764.4$ & $7,029.3$ & $15,554.5$ & $11,626.8$ & $8,468.8$ & 348.3 & $56,201.7$ \\
\hline $10-01-70$ & $2,237.0$ & $8,191.4$ & $32,963.9$ & $4,869.3$ & $6,019.8$ & $14,071.2$ & $7,989.6$ & $7,551.6$ & 255.3 & $46,334.9$ \\
\hline $05-01-71$ & $5,163.0$ & $11,237.8$ & $36,059.1$ & $5,487.0$ & $6,484.1$ & $15,592.7$ & $11,245.6$ & $8,113.5$ & 261.0 & $51,101.5$ \\
\hline $10-01-71$ & $3,992.0$ & $10,779.9$ & $35,007.3$ & $5,208.2$ & $6,085.0$ & $15,447.7$ & $10,586.6$ & $7,795.0$ & 212.2 & $47, C 51.7$ \\
\hline $05-01-72$ & $7,709.7$ & $11,321.6$ & $38,460.2$ & $6,007.4$ & $6,869.7$ & $15,887.6$ & $13,292.0$ & $8,575.4$ & 363.9 & $60,800.1$ \\
\hline $10-01-72$ & $8,005.4$ & $11,144.8$ & $38,442.4$ & $6,025.3$ & $6,952.5$ & $15,596.0$ & $12,528.2$ & $8,597.3$ & 526.9 & $64, C 43.9$ \\
\hline $05-01-73$ & $7,338.6$ & $10,487.9$ & $37,779.1$ & $5,797.0$ & $6,898.8$ & $15,411.6$ & $11,618.6$ & $8,563.4$ & 609.8 & $63, C 15.3$ \\
\hline $10-01-73$ & $4,110.5$ & $9,334.8$ & $34,884.9$ & $5,132.1$ & $6,058.3$ & $14,612.6$ & $8,461.8$ & $7,804.9$ & 504.1 & $54,212.0$ \\
\hline $05-01-74$ & $6,736.6$ & $11,435.3$ & $37,811.3$ & $5,724.1$ & $6,428.9$ & $15,690.9$ & $11,759.0$ & $8,264.9$ & 489.8 & $59,4.04 .7$ \\
\hline $10-01-74$ & $2,386.0$ & $8,834.9$ & $33,690.9$ & $4,799.2$ & $5,356.2$ & $14,209.0$ & $7,773.6$ & $7,245.0$ & 370.5 & $48,4.79 .3$ \\
\hline $05-01-75$ & $4,566.7$ & $11,133.5$ & $35,950.7$ & $5,233.5$ & $5,695.3$ & $15,524.1$ & $10,482.4$ & $7,669.5$ & 368.5 & $51,278.1$ \\
\hline $10-01-75$ & $1,754.4$ & $9,623.3$ & $33,060.4$ & $4,563.2$ & $4,961.4$ & $14,591.6$ & $7,524.7$ & $6,970.1$ & 286.4 & $43,491.7$ \\
\hline $05-01-76$ & $5,822.1$ & $11,662.5$ & $37,291.3$ & $5,457.1$ & $5,487.8$ & $15,854.6$ & $12,322.8$ & $7,559.5$ & 269.3 & $52,2.43 .2$ \\
\hline $10-01-76$ & 0 & $9,002.6$ & $31,374.7$ & $4,217.2$ & $3,744.7$ & $14,077.3$ & $5,632.3$ & $5,735.9$ & 68.9 & $35,483.4$ \\
\hline $05-01-77$ & 0 & $5,902.9$ & $28,897.9$ & $3,572.5$ & $3,505.0$ & $12,656.4$ & $4,362.9$ & $5,568.9$ & 84.0 & $31,515.5$ \\
\hline $10-01-77$ & $2,319.5$ & $8,734.9$ & $29,257.2$ & $3,609.3$ & $3,393.4$ & $13,706.9$ & $3,393.6$ & $5,421.3$ & 55.9 & $29,662.1$ \\
\hline $05-01-78$ & $5,798.3$ & $11,423.3$ & $33,018.4$ & $4,368.9$ & $4,044.4$ & $15,584.4$ & $8,475.2$ & $6,165.2$ & 80.4 & $35,668.0$ \\
\hline $10-01-78$ & $5,514.7$ & $11,045.6$ & $32,981.9$ & $4,305.8$ & $3,991.3$ & $15,521.6$ & $9,499.9$ & $6,141.2$ & 73.0 & $34,729.3$ \\
\hline 05-01-79 & $8,988.9$ & $10,876.5$ & $36,865.6$ & $5,101.9$ & $4,619.1$ & $15,930.9$ & $13,113.8$ & $6,851.4$ & 91.1 & $46,857.8$ \\
\hline $10-01-79$ & $7,212.9$ & $10,472.2$ & $35,492.4$ & $4,762.6$ & $4,289.5$ & $15,463.4$ & $11,321.7$ & $6,539.9$ & 67.8 & $43,191.8$ \\
\hline $05-01-80$ & $7,055.6$ & $10,677.6$ & $35,481.6$ & $4,693.2$ & $4,325.0$ & $15,478.1$ & $11,304.0$ & $6,637.0$ & 75.8 & $42,923.3$ \\
\hline $10-01-80$ & $5,295.0$ & $10,596.0$ & $34,162.3$ & $4,383.9$ & $3,929.1$ & $15,418.9$ & $9,842.1$ & $6,221.4$ & 43.8 & $38,227.6$ \\
\hline $05-01-81$ & $5,271.0$ & $10,733.4$ & $34,212.4$ & $4,327.8$ & $3,980.7$ & $15,474.8$ & $10,358.7$ & $6,328.6$ & 55.8 & $37,774.3$ \\
\hline $10-01-81$ & $2,464.6$ & $9,204.5$ & $31,510.3$ & $3,705.5$ & $3,412.8$ & $14,550.9$ & $7,595.2$ & $5,723.0$ & 30.8 & $31,268.1$ \\
\hline
\end{tabular}


Table B9. Simulated lake volumes, in acre-feet, for the 10 major lakes of the Waubay Lakes Chain, 1963-9ع-Continued

\begin{tabular}{|c|c|c|c|c|c|c|c|c|c|c|}
\hline Date & $\begin{array}{l}\text { Bitter } \\
\text { Lake }\end{array}$ & $\begin{array}{l}\text { Blue Dog } \\
\text { Lake }\end{array}$ & $\begin{array}{l}\text { Enemy } \\
\text { Swim } \\
\text { Lake }\end{array}$ & $\begin{array}{l}\text { Hille- } \\
\text { brands } \\
\text { Lake }\end{array}$ & $\begin{array}{c}\text { Minne- } \\
\text { wasta } \\
\text { Lake }\end{array}$ & $\begin{array}{c}\text { Pickerel } \\
\text { Lake }\end{array}$ & $\begin{array}{l}\text { Rush } \\
\text { Lake }\end{array}$ & $\begin{array}{c}\text { Spring } \\
\text { Lake }\end{array}$ & $\begin{array}{l}\text { S wan } \\
\text { F ind }\end{array}$ & $\begin{array}{c}\text { Waubay } \\
\text { Lake }\end{array}$ \\
\hline $05-01-82$ & $4,772.7$ & $11,194.8$ & $33,954.2$ & 4.175 .1 & $3,860.7$ & $15,584.0$ & $10,817.4$ & $6,249.4$ & 53.3 & $35,247.4$ \\
\hline $10-01-82$ & $2,726.5$ & $9,666.5$ & $31,841.4$ & $3,655.6$ & $3,519.1$ & $14,751.8$ & $8,895.8$ & $5,919.2$ & 48.9 & $30,724.5$ \\
\hline $05-01-83$ & $3,925.6$ & $10,806.0$ & $33,054.2$ & $3,840.8$ & $3,827.7$ & $15,460.0$ & $10,483.2$ & $6,319.0$ & 73.2 & $32,613.1$ \\
\hline $10-01-83$ & $1,479.6$ & $8,882.7$ & $30,455.1$ & $3,228.2$ & $3,354.8$ & $14,412.4$ & $8,081.1$ & $5,828.5$ & 53.5 & $27,058.6$ \\
\hline $05-01-84$ & $3,673.1$ & $11,029.9$ & $32,734.5$ & 3.654 .3 & $3,809.9$ & $15,528.0$ & $10,748.0$ & $6,375.5$ & 78.2 & $30,785.8$ \\
\hline $10-01-84$ & 2,397.2 & $10,427.1$ & $31,389.0$ & $3,323.0$ & $3,525.3$ & $15,295.3$ & $9,415.9$ & $6,080.2$ & 60.6 & $27,193.6$ \\
\hline $05-01-85$ & $4,216.1$ & $11,267.3$ & $33,280.9$ & $3,671.5$ & $3,890.2$ & $15,649.1$ & $11,723.5$ & $6,520.0$ & 79.2 & $31,680.6$ \\
\hline $10-01-85$ & $3,099.7$ & $10,640.5$ & $32,184.7$ & $3,397.5$ & $3,647.2$ & $15,425.3$ & $10,868.4$ & $6,272.1$ & 63.1 & $28,627.9$ \\
\hline $05-01-86$ & $7,809.9$ & $11,886.0$ & $37,289.5$ & $4,433.7$ & $4,648.2$ & $16,004.8$ & $13,465.0$ & $7,368.7$ & 105.4 & $45,556.3$ \\
\hline $10-01-86$ & $10,925.8$ & $12,559.8$ & $38,876.0$ & $5,077.3$ & $5,398.5$ & $15,908.6$ & $13,650.8$ & $8,139.0$ & 139.5 & $60,411.1$ \\
\hline $05-01-87$ & $13,769.1$ & $13,420.6$ & $39,502.6$ & $5,810.6$ & $6,007.0$ & $15,991.7$ & $13,858.2$ & $8,569.3$ & 2.34 .7 & $75,625.2$ \\
\hline $10-01-87$ & $9,109.1$ & $10,349.8$ & $35,544.4$ & $4,925.6$ & $5,074.1$ & 14.523 .6 & $10,449.9$ & $7,658.2$ & 153.6 & $64,655.9$ \\
\hline $05-01-88$ & $8,389.6$ & $10,748.2$ & $35,273.4$ & $4,819.8$ & $4,922.7$ & $15,040.3$ & $10,356.7$ & $7,546.1$ & 129.8 & $61,551.7$ \\
\hline $10-01-88$ & $4,420.7$ & $8,492.1$ & $31,805.7$ & $4,031.9$ & $4,123.8$ & $13,774.5$ & $7,035.7$ & $6,725.1$ & 70.4 & $51,988.1$ \\
\hline $05-01-89$ & $7,440.1$ & $11,335.4$ & $35,158.3$ & $4,708.5$ & $4,670.1$ & $15,564.3$ & $11,100.4$ & $7,350.3$ & 87.5 & $56,905.5$ \\
\hline $10-01-89$ & $4,761.2$ & $10,118.8$ & $32,820.6$ & $4,159.6$ & $4,140.3$ & $14,854.8$ & $8,695.3$ & $6,813.7$ & 55.8 & $50,108.6$ \\
\hline $05-01-90$ & $5,306.1$ & $10,886.2$ & $33,501.2$ & $4,245.8$ & $4,259.9$ & $15,454.1$ & $9,832.1$ & $6,986.4$ & 64.7 & $50,062.3$ \\
\hline $10-01-90$ & $3,430.3$ & $9,981.2$ & $31,699.6$ & $3,798.6$ & $3,910.5$ & $14,890.9$ & $7,977.9$ & $6,644.8$ & 53.1 & $45,097.4$ \\
\hline $05-01-91$ & $4,400.6$ & $10,849.4$ & $32,700.5$ & $3,941.2$ & $4,157.7$ & 15.468 .8 & 9.480 .5 & 6.972 .6 & 73.2 & $46,366.0$ \\
\hline $10-01-91$ & $5,972.8$ & $11,248.7$ & $34,378.4$ & 4.232 .1 & $4,522.0$ & $15,642.5$ & $11,740.0$ & $7,429.7$ & 96.2 & $50,620.3$ \\
\hline $05-01-92$ & $6,555.7$ & $11,187.5$ & $35,158.7$ & $4,345.7$ & $4,648.7$ & $15,605.1$ & $12,123.5$ & $7,613.8$ & 99.8 & $53,180.0$ \\
\hline $10-01-92$ & $5,257.3$ & $10,631.3$ & $34,084.1$ & $4,070.7$ & $4,391.0$ & $15,422.9$ & $11,140.4$ & $7,373.6$ & 81.2 & $49,535.1$ \\
\hline $05-01-93$ & $7,513.6$ & $11,434.0$ & $36,570.4$ & $4,550.9$ & $4,840.2$ & $15,741.1$ & $12,623.4$ & $7,908.8$ & 100.5 & $57,165.2$ \\
\hline $10-01-93$ & 12.478 .0 & $13,706.7$ & $39,346.2$ & $5,660.7$ & $5,938.7$ & $16,110.6$ & $13,920.2$ & $8,657.6$ & 439.2 & $78,036.9$ \\
\hline $05-01-94$ & $26,591.3$ & $11,137.1$ & $40,824.2$ & $6,953.4$ & $8,093.0$ & $16,279.4$ & $18,247.4$ & $9,531.1$ & 763.5 & $107,528.9$ \\
\hline $10-01-94$ & $27,648.7$ & $10,679.5$ & $38,814.4$ & $6,804.6$ & $8,040.2$ & $15,631.7$ & $14,151.2$ & $9,358.0$ & 741.3 & $110,641.1$ \\
\hline $05-01-95$ & $39,870.9$ & $10,487.5$ & $40,313.4$ & $10,174.5$ & $10,409.4$ & $16,084.1$ & $16,911.7$ & $10,460.2$ & $\varepsilon 83.9$ & $133,816.9$ \\
\hline $10-01-95$ & $43,637.2$ & $10,877.4$ & $39,263.0$ & $10,775.2$ & $10,010.9$ & $15,727.9$ & $15,741.2$ & $10,818.9$ & $\varsigma 30.9$ & $143,747.1$ \\
\hline $05-01-96$ & $56,132.7$ & $11,105.9$ & $40,395.1$ & $12,185.8$ & $10,839.4$ & $16,141.2$ & $18,182.8$ & $11,622.1$ & $1,037.4$ & $167,293.7$ \\
\hline $10-01-96$ & $54,163.5$ & $10,363.0$ & $38,502.2$ & $12,190.9$ & $9,587.8$ & $15,459.4$ & $14,507.3$ & $11,543.5$ & $1,026.9$ & $167,379.4$ \\
\hline $05-01-97$ & $81,533.2$ & $10,017.2$ & $43,204.5$ & $15,245.0$ & $10,079.2$ & $16,854.7$ & $15,941.5$ & $21,640.4$ & $2,4.64 .8$ & $219,186.7$ \\
\hline $10-01-97$ & $79,415.7$ & $10,800.6$ & $39,512.3$ & $14,982.2$ & $9,724.3$ & $15,715.5$ & $14,904.6$ & $21,244.5$ & $2,405.7$ & $214,624.9$ \\
\hline $05-01-98$ & $98,881.4$ & $13,104.9$ & $41,920.7$ & $16,882.4$ & $12,257.7$ & $16,445.8$ & $22,430.3$ & $24,088.3$ & $2,\{34.1$ & $246,789.3$ \\
\hline $10-01-98$ & $99,899.6$ & $13,307.8$ & $39,691.8$ & $16,979.9$ & $12,401.0$ & $15,820.8$ & $22,863.7$ & $24,231.7$ & $2,856.0$ & $248,567.4$ \\
\hline
\end{tabular}


Table B10. Probability of Waubay Lake exceeding selected lake levels in each of the next 50 years, using October 1, 1998, starting lake levels

\begin{tabular}{|c|c|c|c|c|c|c|c|}
\hline \multirow{2}{*}{$\begin{array}{l}\text { Water } \\
\text { year }\end{array}$} & \multirow[b]{2}{*}{1,785} & \multicolumn{6}{|c|}{ Exceedance probability (in percent) for lake level (in feet above sea level) } \\
\hline & & 1,790 & 1,795 & 1,800 & 1,805 & 1,810 & 1,815 \\
\hline 1999 & 100 & 100 & 100 & 100 & 5.9 & 0 & 0 \\
\hline 2000 & 100 & 100 & 100 & 100 & 11 & 0 & 0 \\
\hline 2001 & 100 & 100 & 100 & 100 & 15 & 0.01 & 0 \\
\hline 2002 & 100 & 100 & 100 & 99 & 16 & 0.12 & 0 \\
\hline 2003 & 100 & 100 & 100 & 96 & 17 & 0.49 & 0 \\
\hline 2004 & 100 & 100 & 100 & 91 & 18 & 0.75 & 0 \\
\hline 2005 & 100 & 100 & 100 & 84 & 17 & 1.2 & 0.01 \\
\hline 2006 & 100 & 100 & 100 & 77 & 17 & 1.4 & 0.02 \\
\hline 2007 & 100 & 100 & 100 & 70 & 16 & 1.7 & 0.04 \\
\hline 2008 & 100 & 100 & 99 & 65 & 15 & 1.9 & 0.04 \\
\hline 2009 & 100 & 100 & 98 & 60 & 15 & 2.2 & 0.03 \\
\hline 2010 & 100 & 100 & 97 & 56 & 14 & 2.1 & 0.02 \\
\hline 2011 & 100 & 100 & 94 & 52 & 13 & 2.2 & 0.04 \\
\hline 2012 & 100 & 100 & 92 & 50 & 13 & 2.1 & 0.03 \\
\hline 2013 & 100 & 100 & 88 & 47 & 12 & 2.1 & 0.02 \\
\hline 2014 & 100 & 100 & 85 & 45 & 13 & 2.0 & 0.05 \\
\hline 2015 & 100 & 99 & 82 & 43 & 12 & 2.0 & 0.05 \\
\hline 2016 & 100 & 99 & 79 & 42 & 12 & 2.1 & 0.05 \\
\hline 2017 & 100 & 98 & 76 & 40 & 11 & 2.2 & 0.04 \\
\hline 2018 & 100 & 97 & 74 & 39 & 11 & 2.0 & 0.03 \\
\hline 2019 & 100 & 96 & 72 & 38 & 11 & 1.9 & 0.03 \\
\hline 2020 & 100 & 95 & 70 & 37 & 11 & 2.0 & 0.02 \\
\hline 2021 & 100 & 94 & 68 & 36 & 11 & 2.0 & 0.05 \\
\hline 2022 & 100 & 93 & 66 & 35 & 10 & 1.9 & 0.02 \\
\hline 2023 & 100 & 91 & 64 & 34 & 10 & 1.9 & 0.03 \\
\hline 2024 & 100 & 90 & 62 & 33 & 10 & 1.9 & 0.07 \\
\hline 2025 & 99 & 89 & 61 & 33 & 10 & 1.9 & 0.07 \\
\hline 2026 & 99 & 87 & 60 & 32 & 9.4 & 1.8 & 0.03 \\
\hline 2027 & 99 & 86 & 58 & 31 & 9.2 & 1.9 & 0.04 \\
\hline 2028 & 99 & 85 & 58 & 31 & 8.9 & 1.8 & 0.04 \\
\hline 2029 & 98 & 84 & 57 & 31 & 8.8 & 1.8 & 0.06 \\
\hline 2030 & 98 & 82 & 56 & 30 & 9.0 & 1.8 & 0.04 \\
\hline 2031 & 97 & 82 & 55 & 29 & 8.9 & 1.8 & 0.04 \\
\hline 2032 & 97 & 81 & 54 & 29 & 8.8 & 1.7 & 0.06 \\
\hline 2033 & 96 & 80 & 53 & 29 & 8.5 & 1.8 & 0.07 \\
\hline 2034 & 96 & 79 & 53 & 28 & 8.3 & 1.7 & 0.03 \\
\hline 2035 & 96 & 78 & 52 & 28 & 8.3 & 1.8 & 0.04 \\
\hline
\end{tabular}


Table B10. Probability of Waubay Lake exceeding selected lake levels in each of the next 50 years, using October 1, 1998, starting lake levels-Continued

\begin{tabular}{llllllll}
\hline $\begin{array}{l}\text { Water } \\
\text { year }\end{array}$ & \multicolumn{7}{l}{ Exceedance probability (in percent) for lake level (in feet above sea level) } \\
\cline { 2 - 8 } & $\mathbf{1 , 7 8 5}$ & $\mathbf{1 , 7 9 0}$ & $\mathbf{1 , 7 9 5}$ & $\mathbf{1 , 8 0 0}$ & $\mathbf{1 , 8 0 5}$ & $\mathbf{1 , 8 1 0}$ & $\mathbf{1 , 8 1 5}$ \\
\hline 2036 & 95 & 76 & 51 & 28 & 8.3 & 1.8 & 0.05 \\
2037 & 94 & 76 & 50 & 27 & 8.3 & 1.7 & 0.10 \\
2038 & 94 & 75 & 50 & 27 & 8.3 & 1.7 & 0.09 \\
2039 & 94 & 74 & 49 & 27 & 8.1 & 1.6 & 0.07 \\
2040 & 93 & 73 & 49 & 26 & 8.0 & 1.6 & 0.08 \\
2041 & 93 & 73 & 49 & 26 & 8.1 & 1.5 & 0.08 \\
2042 & 92 & 72 & 48 & 26 & 7.9 & 1.5 & 0.09 \\
2043 & 92 & 71 & 48 & 26 & 7.9 & 1.5 & 0.08 \\
2044 & 92 & 71 & 47 & 25 & 8.0 & 1.5 & 0.03 \\
2045 & 91 & 71 & 47 & 25 & 7.8 & 1.5 & 0.05 \\
2046 & 91 & 71 & 47 & 25 & 7.7 & 1.5 & 0.05 \\
2047 & 91 & 70 & 47 & 25 & 7.5 & 1.4 & 0.03 \\
2048 & 90 & 70 & 46 & 24 & 7.3 & 1.4 & 0.03 \\
\hline
\end{tabular}


Table B11. Probability of Waubay Lake exceeding selected lake levels in each of the next 50 years, using October 1,1 1 52 , starting lake levels

\begin{tabular}{|c|c|c|c|c|c|c|c|}
\hline \multirow{2}{*}{$\begin{array}{l}\text { Water } \\
\text { year }\end{array}$} & \multicolumn{7}{|c|}{ Exceedance probability (in percent) for lake level (in feet above sea level) } \\
\hline & 1,785 & 1,790 & 1,795 & 1,800 & 1,805 & 1,810 & 1,815 \\
\hline 1963 & 2.9 & 0 & 0 & 0 & 0 & 0 & 0 \\
\hline 1964 & 8.2 & 0.07 & 0 & 0 & 0 & 0 & 0 \\
\hline 1965 & 17 & 1.3 & 0.03 & 0 & 0 & 0 & 0 \\
\hline 1966 & 24 & 4.2 & 0.42 & 0.03 & 0 & 0 & 0 \\
\hline 1967 & 30 & 8.2 & 1.9 & 0.26 & 0.01 & 0 & 0 \\
\hline 1968 & 35 & 12 & 3.7 & 0.76 & 0.05 & 0 & 0 \\
\hline 1969 & 38 & 15 & 5.9 & 1.7 & 0.22 & 0.02 & 0 \\
\hline 1970 & 41 & 18 & 7.6 & 2.5 & 0.48 & 0.03 & 0 \\
\hline 1971 & 44 & 20 & 9.3 & 3.5 & 0.78 & 0.05 & 0 \\
\hline 1972 & 47 & 22 & 11 & 4.6 & 1.0 & 0.10 & 0 \\
\hline 1973 & 50 & 24 & 12 & 5.4 & 1.5 & 0.13 & 0 \\
\hline 1974 & 52 & 27 & 14 & 6.2 & 1.8 & 0.12 & 0 \\
\hline 1975 & 53 & 28 & 15 & 6.9 & 2.1 & 0.19 & 0 \\
\hline 1976 & 55 & 30 & 16 & 7.8 & 2.2 & 0.24 & 0 \\
\hline 1977 & 57 & 31 & 17 & 8.4 & 2.4 & 0.30 & 0 \\
\hline 1978 & 58 & 33 & 18 & 9.3 & 2.7 & 0.34 & 0.01 \\
\hline 1979 & 60 & 35 & 19 & 10 & 2.9 & 0.34 & 0 \\
\hline 1980 & 62 & 36 & 20 & 11 & 3.1 & 0.31 & 0.01 \\
\hline 1981 & 63 & 38 & 21 & 11 & 3.4 & 0.33 & 0.01 \\
\hline 1982 & 65 & 39 & 23 & 12 & 3.6 & 0.40 & 0.01 \\
\hline 1983 & 66 & 40 & 23 & 12 & 3.6 & 0.47 & 0.01 \\
\hline 1984 & 67 & 41 & 24 & 13 & 3.7 & 0.53 & 0.01 \\
\hline 1985 & 68 & 43 & 25 & 13 & 3.9 & 0.63 & 0.01 \\
\hline 1986 & 69 & 43 & 26 & 14 & 3.9 & 0.60 & 0 \\
\hline 1987 & 70 & 44 & 27 & 14 & 4.0 & 0.64 & 0 \\
\hline 1988 & 71 & 45 & 27 & 14 & 4.1 & 0.73 & 0 \\
\hline 1989 & 71 & 46 & 28 & 15 & 4.3 & 0.85 & 0.02 \\
\hline 1990 & 72 & 47 & 29 & 15 & 4.3 & 0.90 & 0 \\
\hline 1991 & 73 & 48 & 30 & 15 & 4.5 & 0.91 & 0.02 \\
\hline 1992 & 74 & 49 & 30 & 15 & 4.5 & 0.91 & 0.02 \\
\hline 1993 & 74 & 50 & 31 & 16 & 4.7 & 0.92 & 0.03 \\
\hline 1994 & 75 & 51 & 31 & 16 & 5.0 & 0.89 & 0.03 \\
\hline 1995 & 75 & 51 & 32 & 16 & 5.1 & 0.87 & 0.01 \\
\hline 1996 & 76 & 52 & 32 & 17 & 5.2 & 0.97 & 0.02 \\
\hline 1997 & 76 & 52 & 32 & 17 & 5.2 & 1.01 & 0.03 \\
\hline 1998 & 77 & 53 & 33 & 17 & 5.4 & 0.96 & 0.02 \\
\hline 1999 & 77 & 53 & 33 & 17 & 5.5 & 1.0 & 0.03 \\
\hline
\end{tabular}


Table B11. Probability of Waubay Lake exceeding selected lake levels in each of the next 50 years, using October 1, 1962, starting lake levels-Continued

\begin{tabular}{llllllll}
\hline \multirow{2}{*}{$\begin{array}{l}\text { Water } \\
\text { year }\end{array}$} & \multicolumn{7}{c}{ Exceedance probability (in percent) for lake level (in feet above sea level) } \\
\cline { 2 - 8 } & $\mathbf{1 , 7 8 5}$ & $\mathbf{1 , 7 9 0}$ & $\mathbf{1 , 7 9 5}$ & $\mathbf{1 , 8 0 0}$ & $\mathbf{1 , 8 0 5}$ & $\mathbf{1 , 8 1 0}$ & $\mathbf{1 , 8 1 5}$ \\
\hline 2000 & 77 & 54 & 34 & 18 & 5.3 & 1.1 & 0.02 \\
2001 & 78 & 54 & 34 & 18 & 5.5 & 1.1 & 0.04 \\
2002 & 78 & 54 & 35 & 18 & 5.4 & 1.2 & 0.02 \\
2003 & 79 & 55 & 35 & 18 & 5.5 & 1.0 & 0.05 \\
2004 & 78 & 55 & 35 & 18 & 5.9 & 1.0 & 0.06 \\
2005 & 79 & 56 & 35 & 19 & 5.7 & 1.0 & 0.05 \\
2006 & 79 & 56 & 36 & 19 & 5.8 & 1.1 & 0.05 \\
2007 & 79 & 56 & 36 & 19 & 5.9 & 1.0 & 0.06 \\
2008 & 79 & 57 & 36 & 19 & 6.0 & 1.1 & 0.01 \\
2009 & 80 & 57 & 37 & 19 & 5.8 & 1.0 & 0.03 \\
2010 & 80 & 57 & 37 & 19 & 5.8 & 1.0 & 0.04 \\
2011 & 81 & 58 & 37 & 20 & 5.8 & 1.1 & 0.02 \\
2012 & 81 & 58 & 37 & 19 & 5.8 & 1.1 & 0.02 \\
\hline
\end{tabular}


Section C - Explanation of Procedures for Operating the Water Mass-Balance and Stochastic Time-Series Models 

Missing semiannual lake levels were estimated using known lake levels of Hillebrands, Spring, and Waubay Lakes. Explanatory variables considered for estimating the level of a given lake at the end of a time step were as follows:

$\mathrm{CH}$ is the change in the level of Hillebrands Lake during a time step,

CS is the change in the level of Spring Lake during a time step,

$\mathrm{CW}$ is the change in the level of Waubay Lake during a time step,

LH is the level of Hillebrands Lake at the beginning of a time step,

LS is the level of Spring Lake at the beginning of a time step, and

LW is the level of Waubay Lake at the beginning of a time step.

All-subsets regression was used to select the best (largest adjusted coefficient of determination, $\mathrm{R}^{2}$ ) set of explanatory variables for each lake that had missing data. To improve the model fit, separate variables were included depending on whether $\mathrm{CH}, \mathrm{CS}$, or $\mathrm{CW}$ was positive (lake was rising) or negative (lake was falling). For example, $\mathrm{CW}$ was converted to two explanatory variables, $\mathrm{CW}_{+}$and $\mathrm{CW}_{-}$, where

$$
\begin{gathered}
\mathrm{CW}_{+}=\mathrm{I}(\mathrm{CW} \geq 0) \mathrm{CW} \\
\mathrm{CW}_{-}=[1-\mathrm{I}(\mathrm{CW} \geq 0)] \mathrm{CW}
\end{gathered}
$$

with

$$
\mathrm{I}(\mathrm{CW} \geq 0)=\left\{\begin{array}{l}
1, \text { if } \mathrm{CW} \geq 0 \\
0, \text { if } \mathrm{CW}<0
\end{array}\right.
$$

$\mathrm{CH}$ and CS were transformed in a similar manner. The fitted regression equations and adjusted $\mathrm{R}^{2}$ values are as

\begin{tabular}{|c|c|c|}
\hline Bitter Lake & $803.2+0.54 \mathrm{LW}+0.68 \mathrm{CW}+0.89 \mathrm{CW}_{+}$ & 80 \\
\hline Blue Dog Lake & $1,484.2+0.30 \mathrm{LS}+0.61 \mathrm{CH}_{-}+0.30 \mathrm{CS}_{+}-0.13 \mathrm{LW}$ & 72 \\
\hline Enemy Swim Lake ${ }^{1}$ & $320.3+0.83\left[\mathrm{~L}_{\mathrm{O}}\right]+2.17 \mathrm{CS}_{-}+0.63 \mathrm{CS}_{+}$ & 83 \\
\hline Minnewasta Lake & $-1,564.1+1.13 \mathrm{LH}+1.81 \mathrm{CH}_{+}+1.28 \mathrm{LS}-0.53 \mathrm{LW}$ & 62 \\
\hline Pickerel Lake & $1,695.9+0.17 \mathrm{LS}-0.09 \mathrm{LW}+0.68 \mathrm{CS} S_{-}+0.46 \mathrm{CS}_{+}$ & 81 \\
\hline Rush Lake & $1,798.2-1.93 \mathrm{CH}_{-}+2.35 \mathrm{CW}_{-}+0.97 \mathrm{CH}_{+}$ & 87 \\
\hline Swan Pond & $-497.5+1.28 \mathrm{LS}+0.67 \mathrm{CS}_{-}+1.53 \mathrm{CS}_{+}$ & 72 \\
\hline
\end{tabular}
follow:

\begin{tabular}{c|cc} 
Lake & $\begin{array}{c}\text { Regression equation for estimating } \\
\text { lake level at end of time step }\end{array}$ & $\begin{array}{c}\text { Adjusted } \mathrm{R}^{2} \\
\text { (percent) }\end{array}$
\end{tabular}


Procedure C2. Estimating unknown coefficients in the water mass-balance model equations

[vaval is volume available; rdw* is redistributed flow, where * is lake connection number]

Given the proportion of total inflow entering each lake (the $p_{i}$ 's) and the coefficients in the empirical flow-rating equations for rdw1 to rdw4 (the $a_{i}$ 's and $b_{i}$ 's), the algorithm for computing individual lake volumes (procedure $\mathrm{C} 3$ ) can be used to uniquely determine the lake volume of each lake at the end of each winter and summer period for water years 1963-98, given the starting lake volumes at the beginning of a water year (for example, on Oct. 1, 1962). The computed volumes at the end of each period can be compared to the historic volumes, and the unknown coefficients can be adjusted until the computed and historic volumes agree as closely as possible. Many different measures can be used for quantifying how closely the computed and historic lake levels agree. For this study, values for the coefficients were selected to minimize the sum-of-squared deviations between the computed and historic lake volumes for each lake. This was accomplished using nonlinear least-squares regression.

At first, an assumption was made that the proportion of total inflow attributed to each lake (the $\mathrm{p}_{\mathrm{i}}$ 's) was constant throughout the historic period. However, a satisfactory fit was not obtained using this assumptior. Rather, the proportion of total inflow that needed to be attributed to the Bitter Lake drainage basin was higher during 1993-98 (the wet period) than during 1963-92. This finding is consistent with findings by the USACE (task 5) that the contributing drainage area of Bitter Lake increased during the wet period. Therefore, Bitter Lake inflow was computed and removed from the total inflow, and then the remaining inflow was divided among the remaining nine lakes using the formulas given below.

Formulas for dividing total inflow among individual lakes:

$$
\begin{gathered}
\text { Bitter Lake: } \mathrm{Q}_{10}=\mathrm{PBI}_{1}(\mathrm{I}) \text {, for } 1963-92 \\
\mathrm{Q}_{10}=\mathrm{PBI}_{2}(\mathrm{I}) \text {, for } 1993-98
\end{gathered}
$$

Remaining nine lakes: $\mathrm{Q}_{\mathrm{i}}=\mathrm{p}_{\mathrm{i}}\left(1-\mathrm{PBI}_{1}\right)(\mathrm{I})$, for $1963-92$

$$
\mathrm{Q}_{\mathrm{i}}=\mathrm{p}_{\mathrm{i}}\left(\mathrm{I}-\mathrm{PBI}_{2}\right)(\mathrm{I}) \text {, for 1993-98. }
$$

Thus, the model has 11 coefficients for dividing total inflow among the individual lakes ( $\mathrm{PBI}_{1}, \mathrm{PBI}_{2}$, and nine $\mathrm{p}_{\mathrm{i}}{ }^{\text {'s). }}$ The equations for estimating proportions of total inflow for the individual lakes are given in table 8 (the intercept terms in table 8 are explained below). The estimated proportions for 1993-98 are very close to the percent of total area values given in table 5 .

Another modification of the equations used to calculate inflow to individual lakes was needed to achieve an adequate fit between historic and computed volumes for some of the lakes. Consistent gains or losses in the volumes of Enemy Swim Lake, Hillebrands Lake, Minnewasta Lake, Spring Lake, and Swan Pord remained relatively constant during 1963-98 and, thus, were not proportional to total inflow. A possible sourse of these gains or losses is ground-water flow between various lakes in the system. For example, Enemy Swim Lake may discharge ground water to Spring Lake. Although analysis of the ground-water system is beyond the scope of this study, an intercept term was introduced into the model for some lakes in an effort to improve the fit between historic and calculated volumes. The intercept for Enemy Swim Lake (-135 acre-feet per each semiannual period or 270 acre-feet per year; table 8) is consistent with a ground-water loss, and the intercept for Spring Lake (280 acrefeet per semiannual period or 560 acre-feet per year) is consistent with a ground-water gain. Hov'ever, the estimated gain for Spring Lake is about twice as large as the estimated loss for Enemy Swim Lake. The discrepancy could be caused by an estimation error or by ground-water inflow to Spring Lake from a source other than Enemy Swim Lake. The negative intercept for Hillebrands Lake probably is not caused by ground-water loss to Spring Lake because Spring Lake was higher than Hillebrands Lake for most of the historic period. However, Hillebrands Lake may discharge ground water to Waubay Lake. The small intercept for Swan Pond 
(30 acre-feet per semiannual period) and the substantial intercept for Minnewasta Lake (170 acre-feet per semiannual period) may indicate a source of ground-water inflow to those lakes as well.

The rating equations used to calculate the redistributed flows are given in table 9 . The multipliers and exponents in the first four lake connections listed in the table were estimated from the historic data (the exponent for rdw 1 is equal to one). When the exponent was larger than one, such as for the rating curves for rdw3 and rdw4, values were computed for the volume available after the incremental amount spilled exceeds the incremental increase in vo'ume available (for example, when the derivative with respect to a vaval exceeds one). Those values were computed to be about 10,000 acre-feet for rdw3 and 25,000 acre-feet for rdw4. Therefore, the flow ratings were curtailed at those values and all available water in excess of those values is allowed to spill.

Although no coefficients were estimated in computing rdw5 to rdw10, the assumption used to compute the remaining redistributed flows is described in procedure $\mathrm{C} 3$. 
Given the precipitation, evaporation, total inflow, and spill elevation data developed in the previous sections, a regression procedure was developed to estimate inflow to individual lakes and flow between lakes. The regression procedure is based on the computational algorithm described in this section for computing the volume of each lake at the end of each time step. Unknown coefficients needed in the algorithm for computing lake volumes were estimated using nonlinear least-squares regression to minimize the sum-of-squared deviations between historic lake volumes and fitted lake volumes. The estimation procedure is described in procedure $\mathrm{C} 2$, and comparisons are made between fitted and historic lake levels.

The algorithm for computing lake volumes is based on the water mass-balance model equations given in table 6 . The volumes (the $V_{0}$ 's and $V_{1}$ 's), the precipitation (p), and the evaporation (e) in the water mass-balance equations are known for each time step in the historic 1963-98 period. The total inflow to all 10 lakes (I) also has been estimated for each time step. To estimate inflow to the individual lakes (the $\mathrm{Q}_{i}$ 's), the simplifying assumption was made that the inflow to each lake is proportional to the total inflow to all 10 lakes,

$$
\mathrm{Q}_{\mathrm{i}}=\mathrm{p}_{\mathrm{i}} \mathrm{I} \text {, }
$$

where the $\mathrm{p}_{\mathrm{i}}$ 's will be estimated from the historic data as described below.

The redistributed flows given in table 6 are ordered approximately according to spills from upstream to downstream lakes. Therefore, the flows between lakes were calculated sequentially. For the first four spills (Pickerel to Waubay, Enemy Swim to Blue Dog, Blue Dog to Rush, and Rush to Waubay), an empirical (for example, data-based) flow rating was developed to regulate each of the spills, given that the upstream and downstream lakes are separate bodies of water. The upstream and downstream lakes are assumed in the model to be separate lakes if the downstream lake is below the spill elevation with the upstream lake. In that case, the empirical flow ratings for the first four spills (assuming initially that the redistributed flows are zero for all other spills beside the first four) are represented by the following equations:

$$
\begin{gathered}
\text { rdw1 = a1 }\left[\mathrm{V}_{1}+(\mathrm{p}-\mathrm{e})\left(\mathrm{A}_{1}\right) / 12+\mathrm{Q}_{1}-\mathrm{SPLV}_{1}\right]_{+}{ }_{1} \\
\operatorname{rdw} 2=\mathrm{a} 2\left[\mathrm{~V}_{2}+(\mathrm{p}-\mathrm{e})\left(\mathrm{A}_{2}\right) / 12+\mathrm{Q}_{2}-\mathrm{SPLV}_{2}\right]_{+}{ }_{2} \\
\mathrm{rdw} 3=\mathrm{a} 3\left[\mathrm{~V}_{3}+(\mathrm{p}-\mathrm{e})\left(\mathrm{A}_{3}\right) / 12+\mathrm{Q}_{3}+\mathrm{rdw} 2-\mathrm{SPLV}_{3}\right]_{+} \mathrm{b}_{3} \\
\text { rdw4 }=\mathrm{a} 4\left[\mathrm{~V}_{4}+(\mathrm{p}-\mathrm{e})\left(\mathrm{A}_{4}\right) / 12+\mathrm{Q}_{4}+\mathrm{rdw} 3-\mathrm{SPLV}_{3}\right]_{+}{ }_{4}
\end{gathered}
$$

where

$\mathrm{rdw}^{*}$ is redistributed flow, where $*$ is lake connection number;

$\mathrm{V}_{1}, \mathrm{~A}_{1}$, and $\mathrm{Q}_{1}$ are the starting volume, starting area, and inflow for Pickerel Lake for a given time step;

$\mathrm{V}_{2}, \mathrm{~A}_{2}$, and $\mathrm{Q}_{2}$ are the starting volume, starting area, and inflow for Enemy Swim Lake for a given time step;

$\mathrm{V}_{3}, \mathrm{~A}_{3}$, and $\mathrm{Q}_{3}$ are the starting volume, starting area, and inflow for Blue Dog Lake for a giver time step;

$\mathrm{V}_{4}, \mathrm{~A}_{4}$, and $\mathrm{Q}_{4}$ are the starting volume, starting area, and inflow for Rush Lake for a given timo step;

$\mathrm{SPLV}_{1}$ is the volume of Pickerel Lake at its spill elevation with Waubay Lake;

$\mathrm{SPLV}_{2}$ is the volume of Enemy Swim Lake at its spill elevation with Blue Dog Lake;

$\mathrm{SPLV}_{3}$ is the volume of Blue Dog Lake at its spill elevation with Rush Lake;

$\mathrm{SPLV}_{4}$ is the volume of Rush Lake at its spill elevation with Waubay Lake;

$a 1, \ldots, a 4$ and $b 1, \ldots, b 4$ are coefficients to be fitted on the basis of historic data; and

$[\ldots]_{+}$indicates that the quantity in brackets is replaced by zero if it is negative. 
The previous equations for rdw1 to rdw4 are used only if the volume spilled from the upstream lake is not large enough to fill the downstream lake to the spill elevation, in which case no backwater flows from the downstraam lake. This situation always holds for the first two spills because the spill elevations for Enemy Swim and Pickerel Lakes are both well above the elevation at which the other eight lakes join and eventually spill to the Big Sio'Ix River. However, Rush Lake can rise above the spill elevation with Blue Dog Lake, and Waubay Lake can rise above the spill elevation with Rush Lake. In such cases, the spill volume is calculated such that the upstream and downstream lakes are at the same level, and the two lakes are treated as a single body of water until the downstream lake again falls below the spill elevation with the upstream lake. For example, if after calculation of rdw3, Blue Dog and Rush Lakes join and then Rush Lake spills to Waubay Lake as indicated by a positive value for rdw4, then Blue Dog and Rush Lakes need to be rebalanced if necessary to maintain the same level. Thus, rdw3 needs to be adjusted accordingly. If Waubay Lake also is above its spill elevation with Rush Lake, then rdw3 and rdw4 need to be adjusted iteratively until Blue Dog, Rush, and Waubay Lakes are balanced.

After Blue Dog, Rush, and Waubay Lakes are balanced, then other lakes are included, one at a time, in the water mass-balance algorithm. First, Hillebrands Lake is included. If Waubay Lake is below the spill elevation with Hillebrands Lake, then rdw5 is zero and rdw 3 and rdw4 do not need to be adjusted any further. However, if Waubay Lake is above the spill elevation with Hillebrands Lake, then Waubay Lake is allowed to spill to Hillebrands Iake until Waubay Lake either falls back to its spill elevation with Hillebrands Lake or Waubay Lake and Hillebre nds Lake are at the same level. Then, rdw3, rdw4, and rdw5 are adjusted as necessary to rebalance Blue Dog, Rush, Waubay, and Hillebrands Lakes. No rating curve was developed to regulate flow between Waubay and Hillebrands Lakes because Waubay Lake is much larger than Hillebrands Lake and will, therefore, fill Hillebrands Lake if it rises slightly above the spill elevation.

After Blue Dog, Rush, Waubay, and Hillebrands Lakes are balanced, then Spring Lake, Swan Pond, and Minnewasta Lake are included one at a time with the preceding lakes until all seven lakes are balanced. As was the case with rdw5, no spill ratings were developed for calculating rdw6, rdw7, or rdw8 because Spring Lake, $\mathbf{S}$ van Pond, and Minnewasta Lake generally fill up quickly once the upstream lake exceeds the spill elevation.

Spill ratings for Rush Lake to Bitter Lake (rdw9) and Bitter Lake to the Big Sioux River (rdw10) needed to ha? developed as well. Unlike rdw1 to rdw4, an empirical flow-rating equation could not be developed for rdw9 or rdw10 because no historic data are available for when either spill took place. Therefore, the last two spill calculations are based on daily flow ratings supplied by the U.S. Army Corps of Engineers. These flow ratings are available at the U.S. Geological Survey Subdistrict office in Huron, S. Dak.

A continuous curve (relating lake levels to flow) was used to approximate the daily flow rating for Rush Lake to Bitter Lake, with the following results:

where

$$
\begin{gathered}
\mathrm{DF}_{9}=160(\mathrm{LRU}-1,803.6) /(1,811.5-1,803.6), \text { if } \mathrm{LBI}<1,803.6<\mathrm{LRU}<1,811.5 \\
\mathrm{DF}_{9}=160(\mathrm{LRU}-\mathrm{LBI}) /(1,811.5-\mathrm{LBI}), \text { if } 1,803.6<\mathrm{LBI}<\mathrm{LRU}<1,811.5
\end{gathered}
$$

$\mathrm{DF}_{9}=$ daily flow from Rush Lake to Bitter Lake, in acre-feet;

LRU = the level of Rush Lake, in feet; and

$\mathrm{LBI}=$ the level of Bitter Lake, in feet. 
If Rush Lake is above 1,811.5 feet, then the railroad embankment is overtopped and flow is assumed to be unimpeded. If Rush Lake is below 1,803.6 feet (the spill elevation with Bitter Lake), no flow is allowed. Although Bitter Lake may never spill into Rush Lake, if that situation does occur, the water is allowed to flow from Bitter Lake to Rush Lake until the levels of the two lakes are the same or until Bitter Lake is below the spill elevation.

After rdw 1 to rdw8 are computed, as described earlier, rdw9 is computed as follows. The increase in the volume of Rush Lake from the beginning of the time step,

$$
\operatorname{IVRU}=(\mathrm{p}-\mathrm{e})\left(\mathrm{A}_{4}\right) / 12+\mathrm{Q}_{4}+\mathrm{rdw} 3-\mathrm{rdw} 4-\mathrm{rdw8},
$$

is assumed to occur at a constant daily rate (IVRU divided by the number of days in the time step). The volume of Rush Lake is increased on a daily basis and the daily flows $\left(\mathrm{DF}_{9}\right)$ are computed for each day. Tha value of rdw9 is the sum of the daily spills for the time step. If rdw9 is not zero, then rdw3 to rdw8 need to be adjusted to rebalance the first nine lakes.

If, after the 10 lakes are balanced, Bitter Lake is below the spill elevation with the Big Sioux River, then rdw10 is zero. If Bitter Lake is above the spill elevation, then rdw 10 is computed using a daily time step, in a similar manner to that used for rdw9, by using the following daily flow rating:

where

$$
\mathrm{DF}_{10}=64(\mathrm{LBI}-1,813.0)^{2.48}, \text { if } \mathrm{LBI}>1,813.0
$$

$\mathrm{DF}_{10}=$ daily flow from Bitter Lake to the Big Sioux River, in acre-feet.

The increase in volume of Bitter lake from the beginning of the time step,

$$
\operatorname{IVBI}=(\mathrm{p}-\mathrm{e})\left(\mathrm{A}_{10}\right) / 12+\mathrm{Q}_{10}+\mathrm{rdw} 9,
$$

is assumed to occur at a constant daily rate. The daily flows $\left(\mathrm{DF}_{9}\right)$ are computed for each day, and the value of rdw 10 is the sum of the daily flows for the time step. If rdw 10 is not zero, then lakes 3 through 10 are rebalanced so that they all have the same level.

Finally, after balancing all 10 lakes, the levels of the lakes at the end of the time step become the starting levels for the next time step, and the balancing algorithm is repeated. 
Procedure C4. Operating the water mass-balance and stochastic time-series models for the Waubay Lakes Chain

Open input file $\mathrm{A}$ and read the number of traces to generate and the number of years per trace.

Set the spill elevations between all 10 lakes.

Read the starting levels for all 10 lakes from input file A for the first time step.

Compute the starting areas and volumes for all 10 lakes.

\section{(A) Do a trace.}

Open input file B to read the precipitation (p), evaporation (e), and total inflow (f) data for each lake and time step or generate these data using the time-series model.

Convert total inflow from thousand acre-feet to acre-feet.

\section{(B) Do a time step.}

If not the first time step, reset starting conditions for this time step to ending conditions of the previous time step.

Compute $\mathrm{p}$ volume - e volume + inflow.

Inflow to an individual lake is computed using the regression equation for that lake.

Compute the volume of each lake at the end of the time step; no flow between lakes is assumed.

Set the flow between all lakes equal to zero.

Compute the flow between Pickerel and Waubay Lakes using rating equations. If Pickerel Lake is below the spill elevation, set the flow between lakes equal to zero.

Compute the flow between Enemy Swim and Blue Dog Lakes using rating equations. If Enemy Swim Lake is below the spill elevation, set the flow between lakes equal to 0 .

Compute the flow between the remaining lakes (lakes 3 through 10; see fig. 9 for numbering scheme).

\section{(C) Add a lake connection.}

Set a counter (icxx) equal to zero so the iterations of the model can be counted to avoid an endless loop; will later check the counter and allow only 50 iterations).

Set a variable (istop) equal to zero; this variable allows an upstream lake to spill only once to a downstream lake when the upstream lake is above the spill elevation and the downstream lake is below the spill elevation; for example, Blue Dog Lake to Rush Lake. 
(D)

Increment the counter (icxx) by one.

Set a variable (ichk) to zero; if ichk equals zero, the two lakes in consideration are balanced; if ichk equals 1 , the two lakes need more balancing (more iterations are needed).

(E) Balance a group of lake connections.

Groups of lake connections are 3-3, 3-4, 3-5, 3-6, 3-7, 3-8, 3-9, and 3-10.

Start with one lake connection in the group, balance the lakes, add another lake connection, and then balance all the lakes in that group; continue this process until all lakes are balanced for this time step.

Do the Blue Dog Lake to Rush Lake connection.

Recompute the level of each lake using the applicable equation for that lake and taking into account any changes to the flow between lakes from a previous iteration.

Balance the lake levels depending on the lake-level condition:

(Condition 1) - If the levels of Blue Dog and Rush Lakes are both less than or equal to the spill elevation, these lakes are balanced; balance the lakes in the next lake connection in the group (go to E).

(Condition 2) - If the levels of Blue Dog and Rush Lakes are both greater than the spill elevation, then:

if the levels of the two lakes are greater than or equal to 0.1 foot, set the variable ichk equal to 1 so more balancing is needed (the levels are not within 0.1 foot of each other).

Compute the areas of the two lakes using their levels.

Use these areas to weight the levels to balance the levels of the two lakes.

Compute the flow between the lakes using the new lake level of Blue Dog Lake.

(Condition 3) - If the level of Blue Dog Lake is greater than the spill elevation and the level of Rush Lake is less than or equal to the spill elevation and variable to tell if Blue Dog Lake has spilled to Rush Lake in a previous iteration $=0($ istop $=0)$,

then

Set the variable to see if more balancing is needed between the two lakes (need more balancing, irhk equals 1 ) Compute the volume available to spill from Blue Dog Lake to Rush Lake.

Compute the volume needed to raise Rush Lake 1 acre-foot above its spill elevation.

Compute the volume that can spill from Blue Dog Lake to Rush Lake using a rating curve (see table 10).

If Rush Lake can take all water that spills from Blue Dog Lake and still be less than the spill elevation, then spill this volume to Blue Dog Lake.

If Rush Lake raises more than 1 acre-foot above its spill elevation when Blue Dog Lake spills, set R ush Lake 1 acrefoot above its spill elevation; now both lakes will be above their spill elevations and ichk still eqvals 1 so more iteration is needed; however, on the next iteration, this lake connection will fall under condition 2 .

Set the variable istop equal tol so Blue Dog Lake does not spill again to Rush Lake. 
Procedure C4. Operating the water mass-balance and stochastic time-series models for the Waubay Lakes Chain-Continued

(Condition 4) - If the level of Blue Dog Lake is less than or equal to the spill elevation and the level of Rush Iake is greater than the spill elevation,

then:

If the levels of the two lakes are greater than or equal to 0.1 foot, set the variable ichk equal to 1 so more balanning is needed (the levels are not within 0.1 foot of each other).

Compute the volume needed to raise Blue Dog Lake 1 acre-foot above its spill elevation.

Compute the volume available to spill from Rush Lake to Blue Dog Lake.

If Blue Dog Lake raises more than 1 acre-foot above its spill elevation, then transfer this water so both lakes are above their spill elevations; ichk is still equal to 1 so more iteration is needed; however, on the next iteration, the lake connection will fall under condition 2.

If too little water can spill from Rush Lake to fill Blue Dog Lake above its spill elevation, then transfer all w'ter from Rush Lake until it is at its spill elevation (Blue Dog Lake will still be below its spill elevation and Rush I_ake will be at its spill elevation, and ichk equals 1 so more iteration is needed; however, on the next iteration, the lake connection will fall under condition 1.

Balance the lakes in the next lake connection in the group (go to $\mathbf{E}$ ) until all lake connections have been considered. (Note that lake connections 3-9 and 3-10 are handled differently ( 7 conditions). These procedures are discussed in more detail in the main body of the report.)

Repeat iterating (go to D) until all lakes in the lake connections are balanced or until 50 iterations have been completed (ichk equals 0 and the counter is less than or equal to 50).

Add another lake connection (go to $\mathbf{C}$ ). Keep adding one new lake connection until all eight lake connectior 9 (3-10) have been added.

Save the final volumes for each lake for that time step.

If any volumes of the 10 lakes are less than or equal to zero, set the volume of the lake equal to zero.

Save the final lake levels, areas, and inflows for each lake for that time step.

Do the next time step (go to B) until all time steps have been done.

Write to output file $C$ the final levels for each lake and time step.

Write to output file D the precipitation data (input or generated) for each lake and time step.

Write to output file $E$ the evaporation data (input or generated) for each lake and time step.

Write to output file $F$ the total inflow data (input or generated) for each lake and time step.

Write to output file $\mathrm{G}$ the final redistributed flows for each lake and time step.

Write to output file $\mathrm{H}$ the final volumes for each lake and time step.

Write to output file I the final areas for each lake and time step.

Do the next trace (go to A) until all traces have been done. 

Section D - Figures 



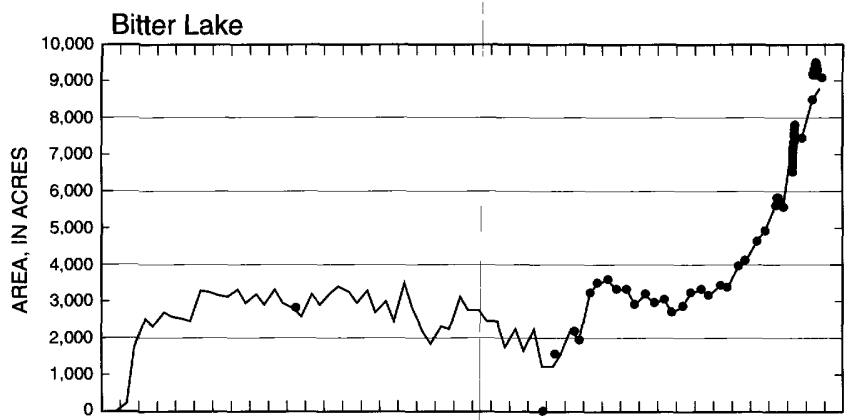

Blue Dog Lake
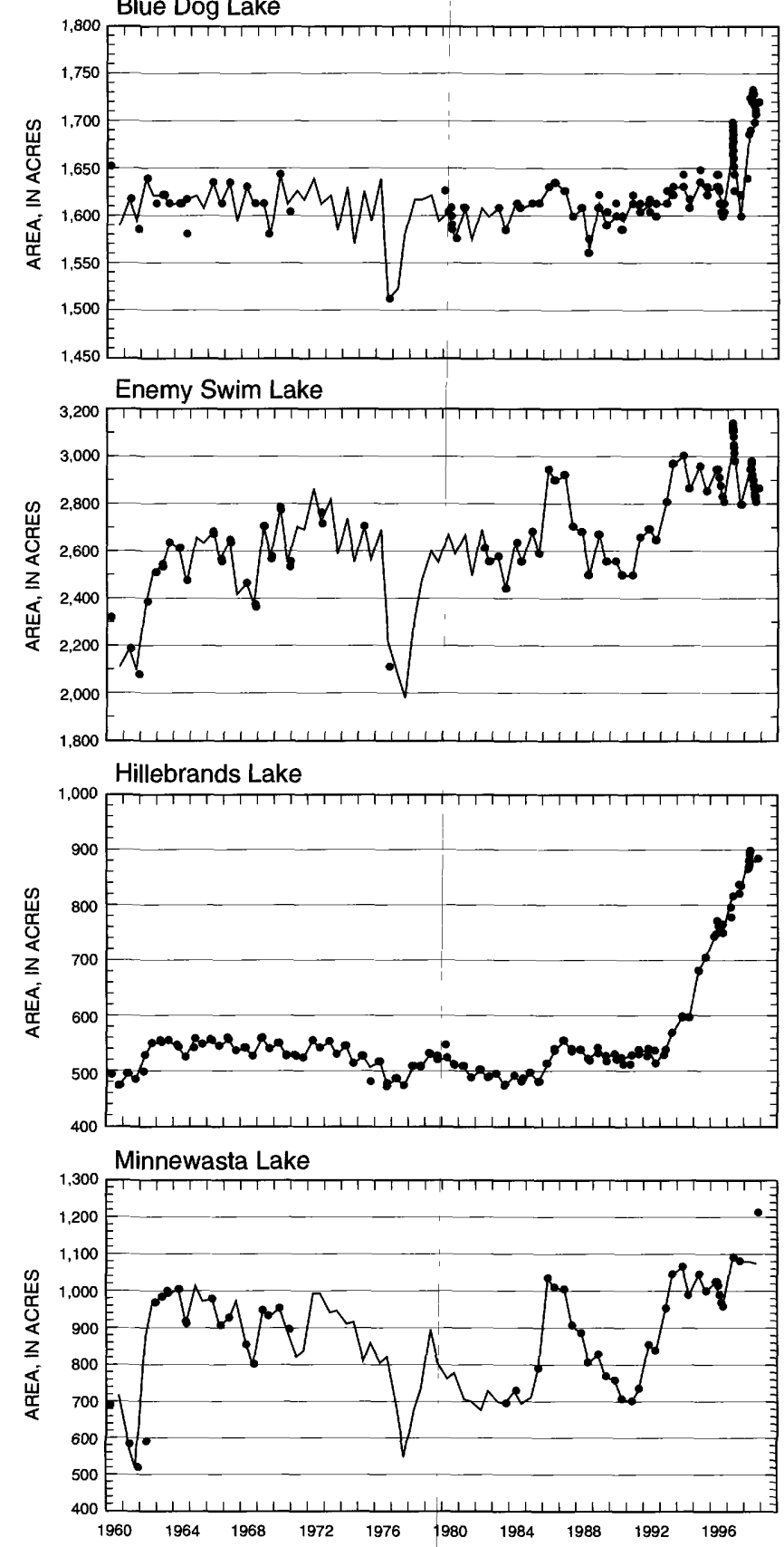
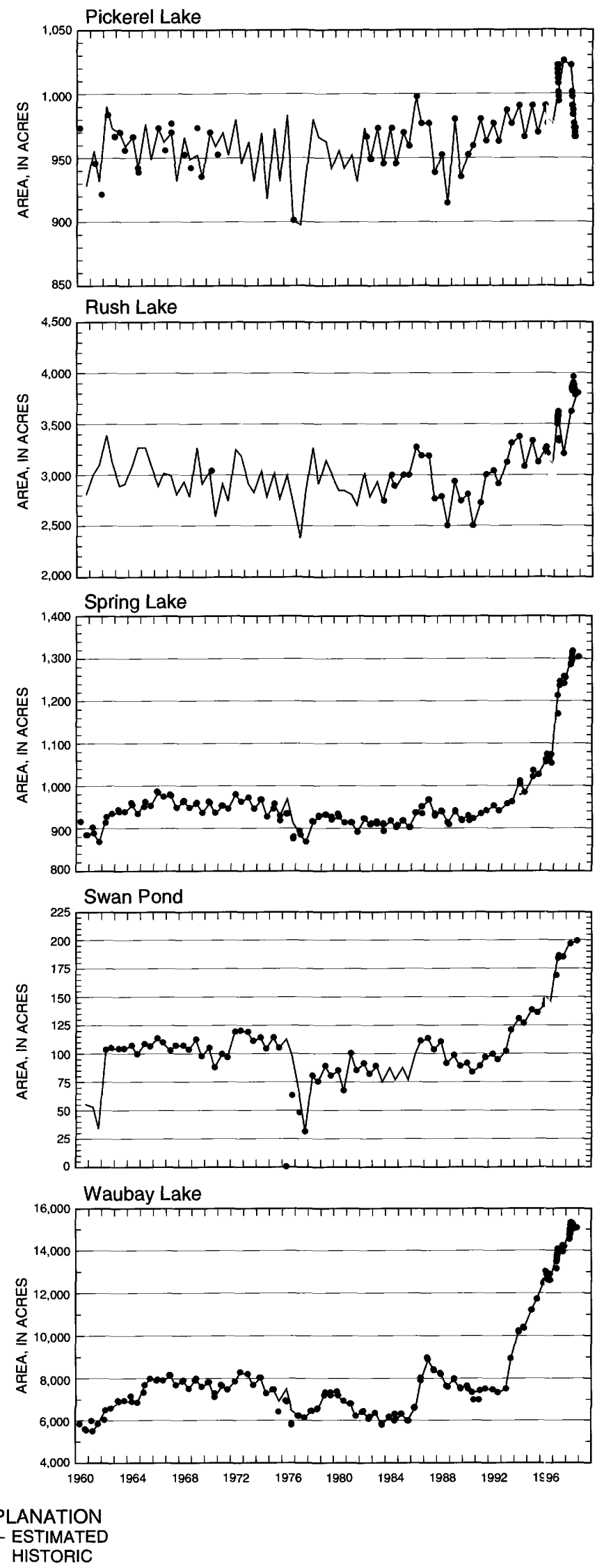

Figure D1. Estimated and historic lake areas of individual lakes within the Waubay Lakes Chain, 1960-98. 

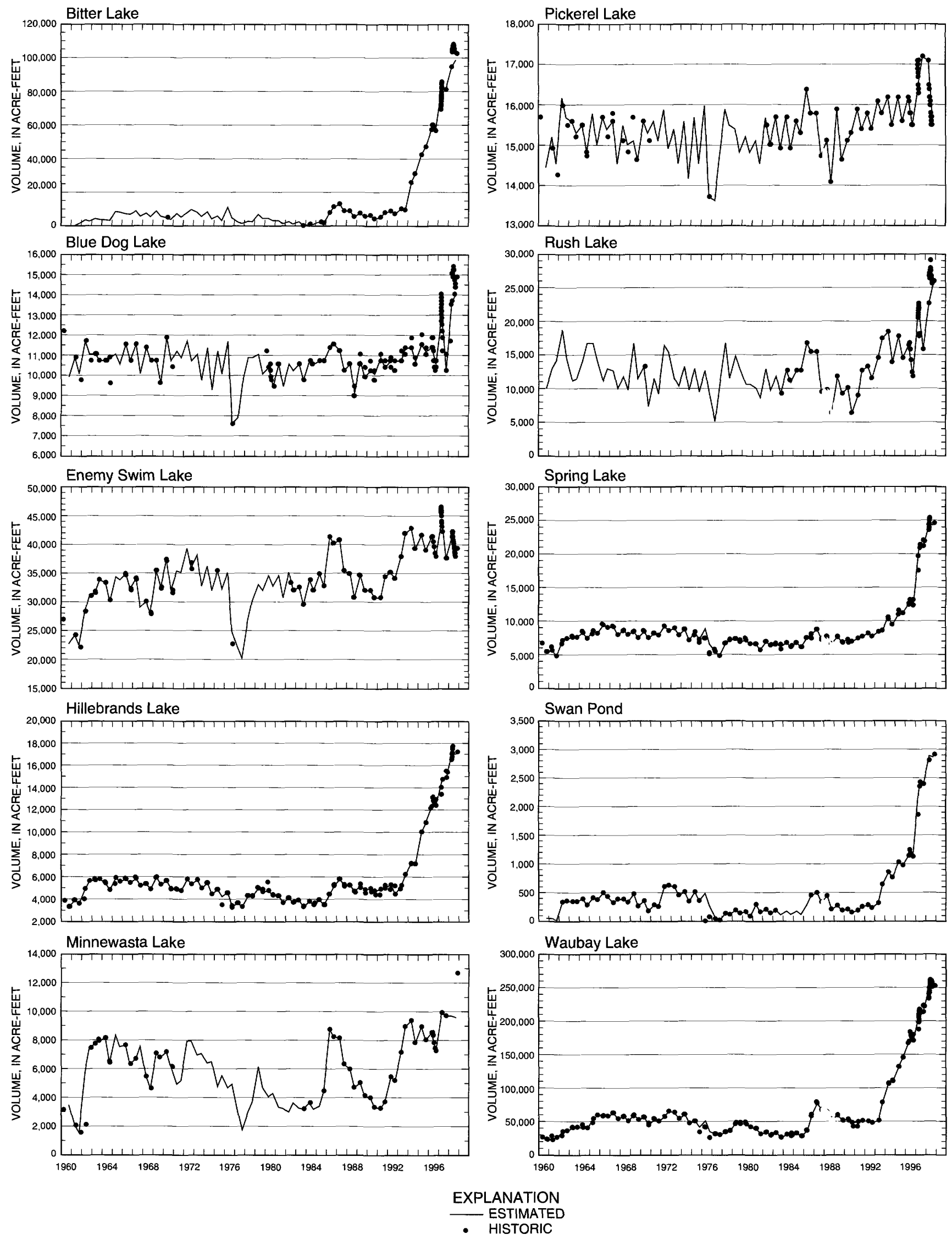

Figure D2. Estimated and historic lake volumes of individual lakes within the Waubay Lakes Chain, $1960-\varsigma^{\circ}$. 


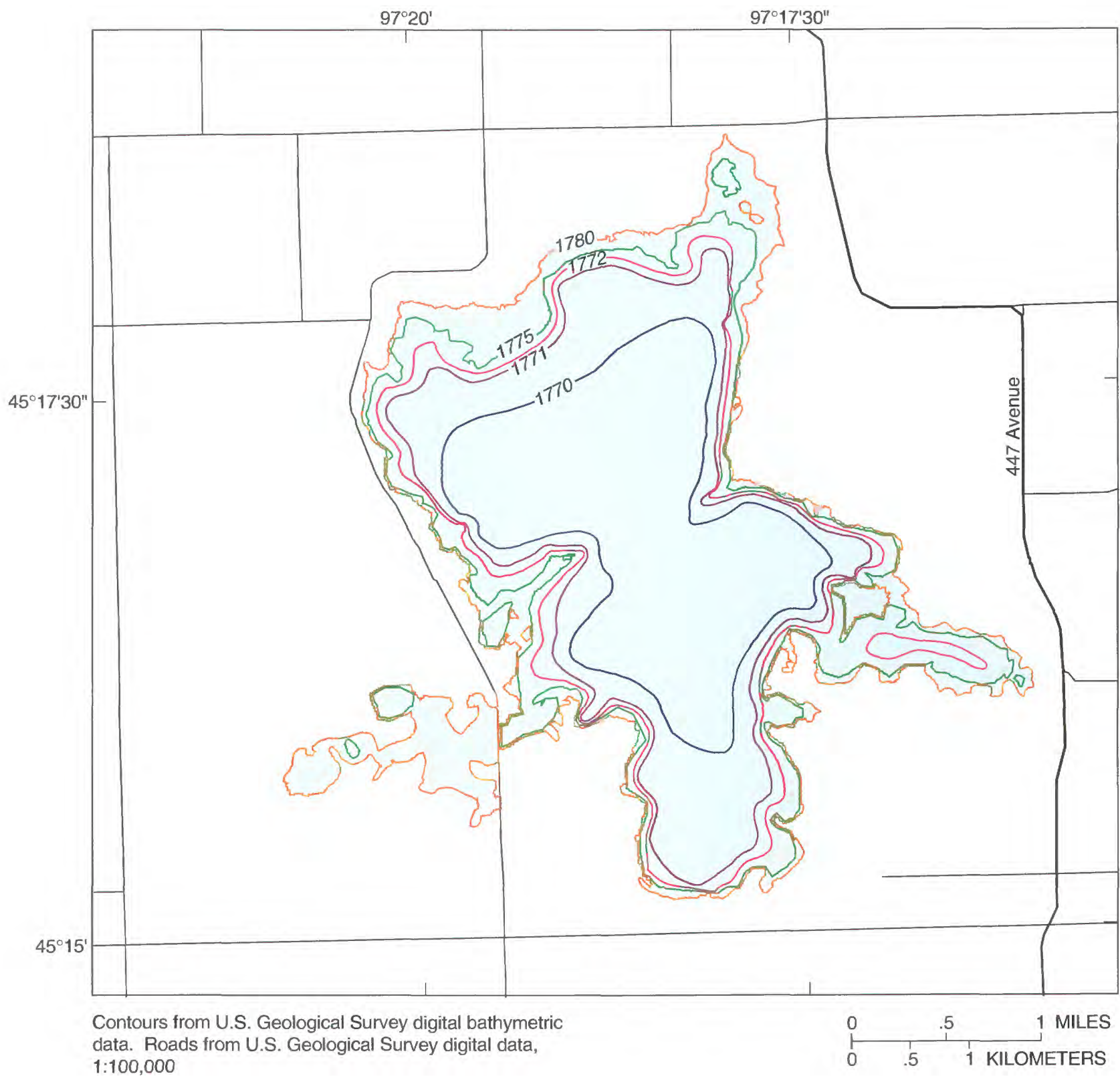

data. Roads from U.S. Geological Survey digital data, $1: 100,000$

- 1775 - BATHYMETRIC CONTOUR--Shows elevation of lake bottom, in feet above sea level. Contour intervals, varied. Colors used to differentiate contours.

Figure D3. Bathymetric data for Bitter Lake. 


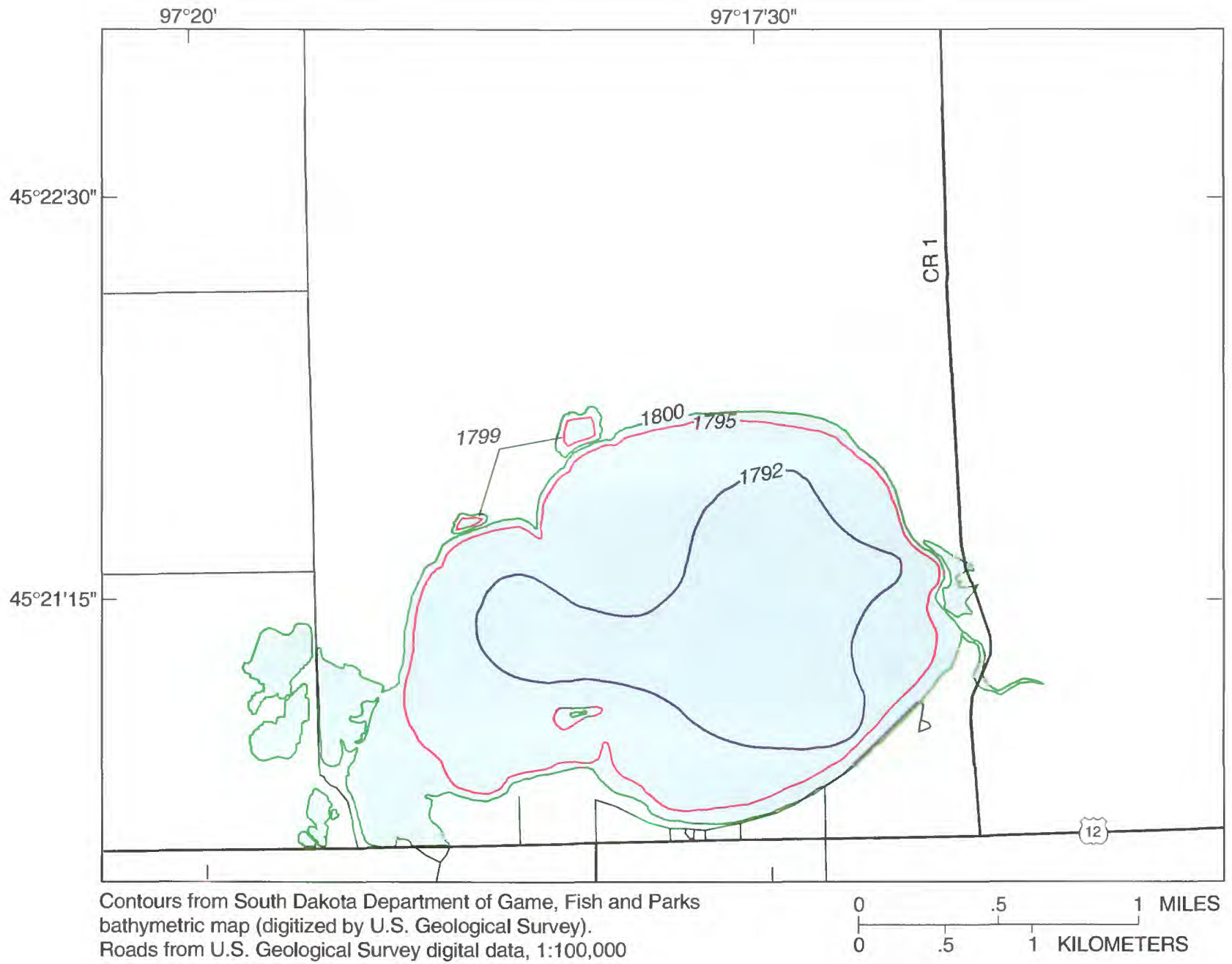

\section{EXPLANATION}

- 1800- BATHYMETRIC CONTOUR--Shows elevation of lake bottom, in feet above sea level. Contour intervals, varied. Colors used to differentiate contours

Figure D4. Bathymetric data for Blue Dog Lake. 


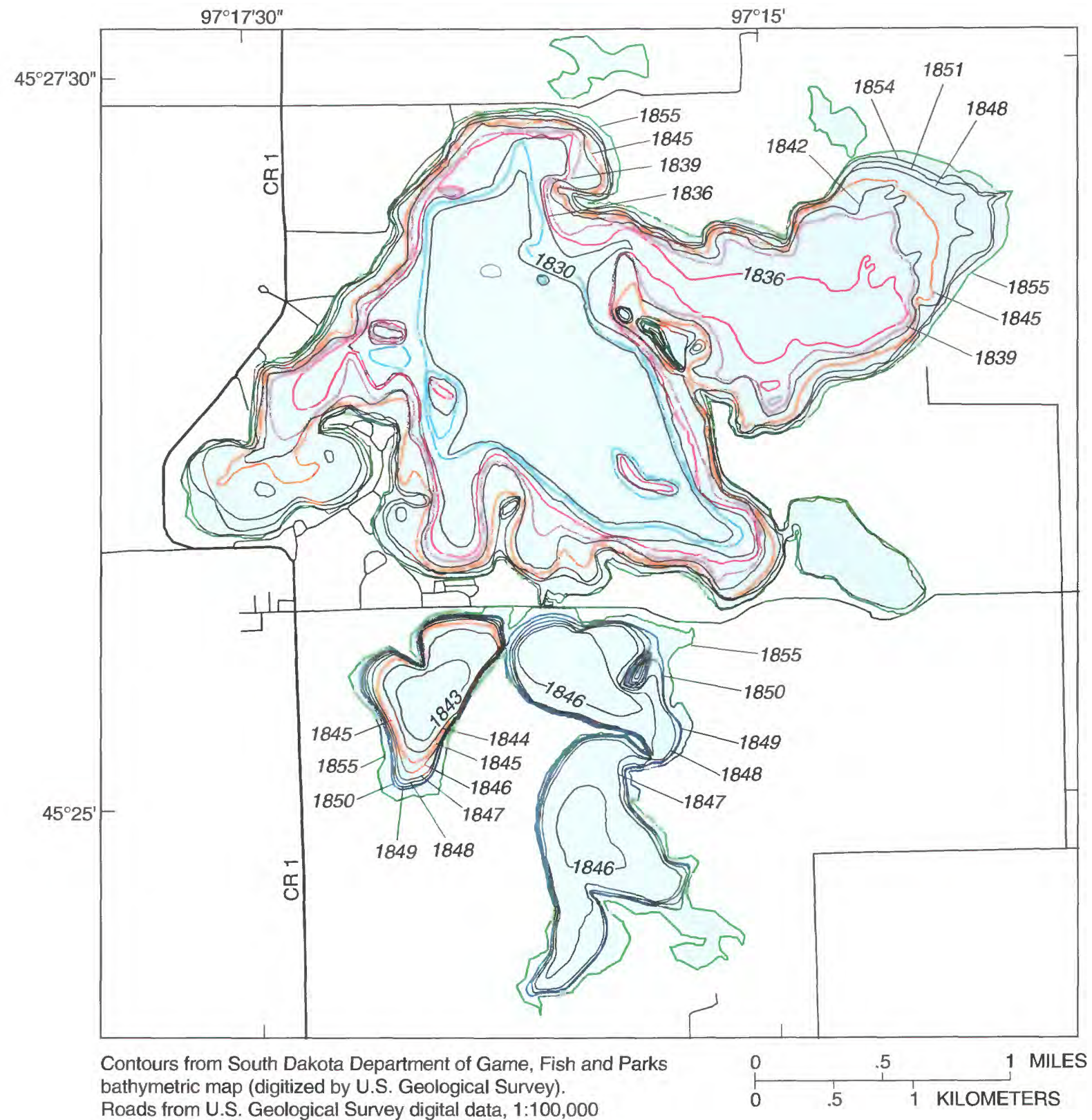

Roads from U.S. Geological Survey digital data, 1:100,000

\section{EXPLANATION}

- 1850- BATHYMETRIC CONTOUR--Shows elevation of lake bottom, in feet above sea level. Contour intervals, varied. Colors used to differentiate contours

Figure D5. Bathymetric data for Enemy Swim Lake. 


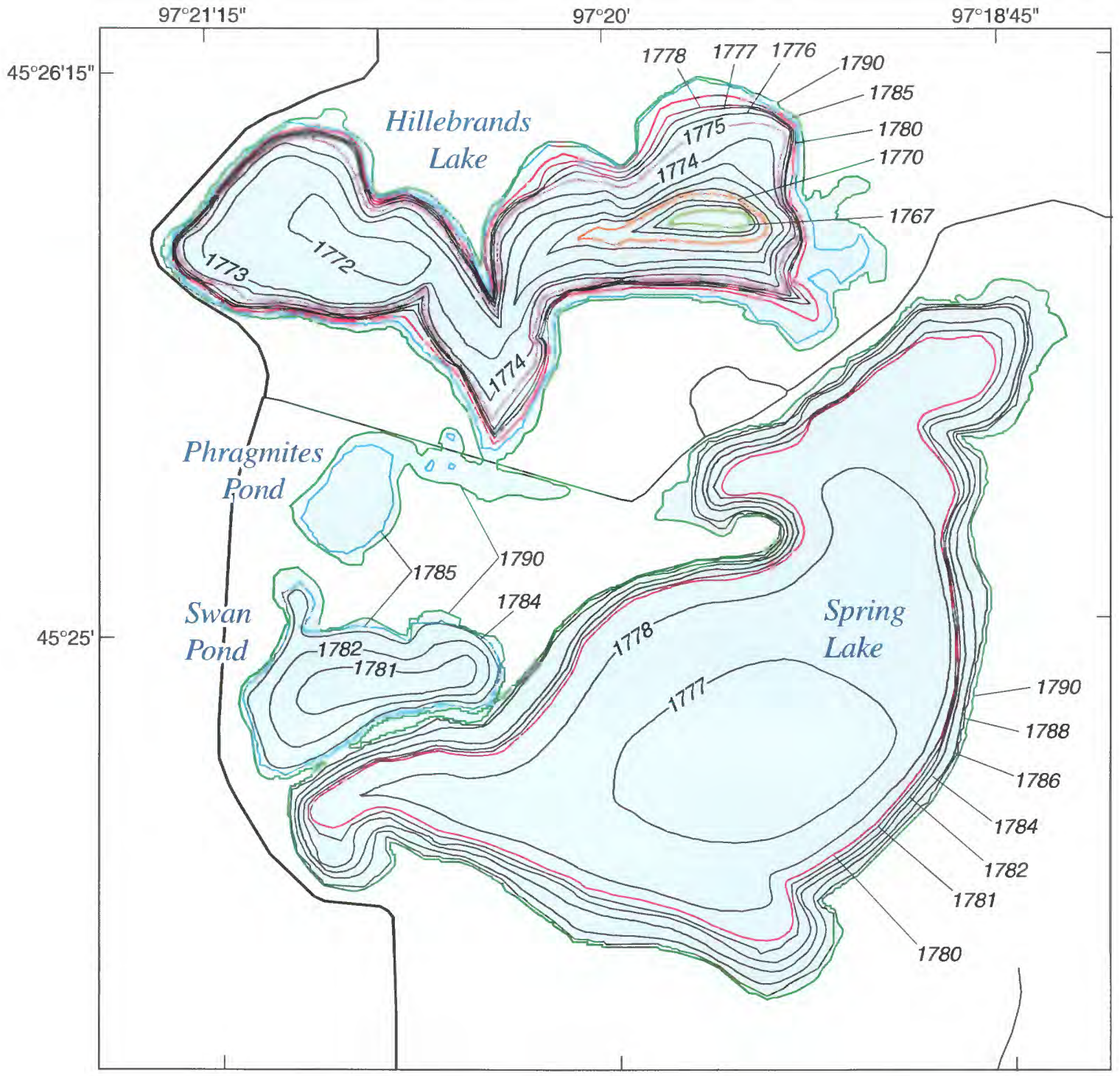

Contours from U.S. Geological Survey digital bathymetric data. Roads from U.S. Geological Survey digital data, $1: 100,000$

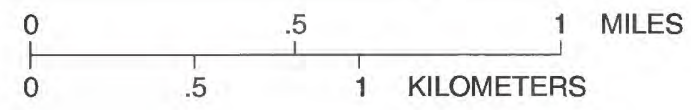

\section{EXPLANATION}

- 1780 - BATHYMETRIC CONTOUR--Shows elevation of lake bottom, in feet above sea level. Contour intervals, varied. Colors used to differentiate contours

Figure D6. Bathymetric data for Hillebrands Lake, Spring Lake, and Swan Pond. 


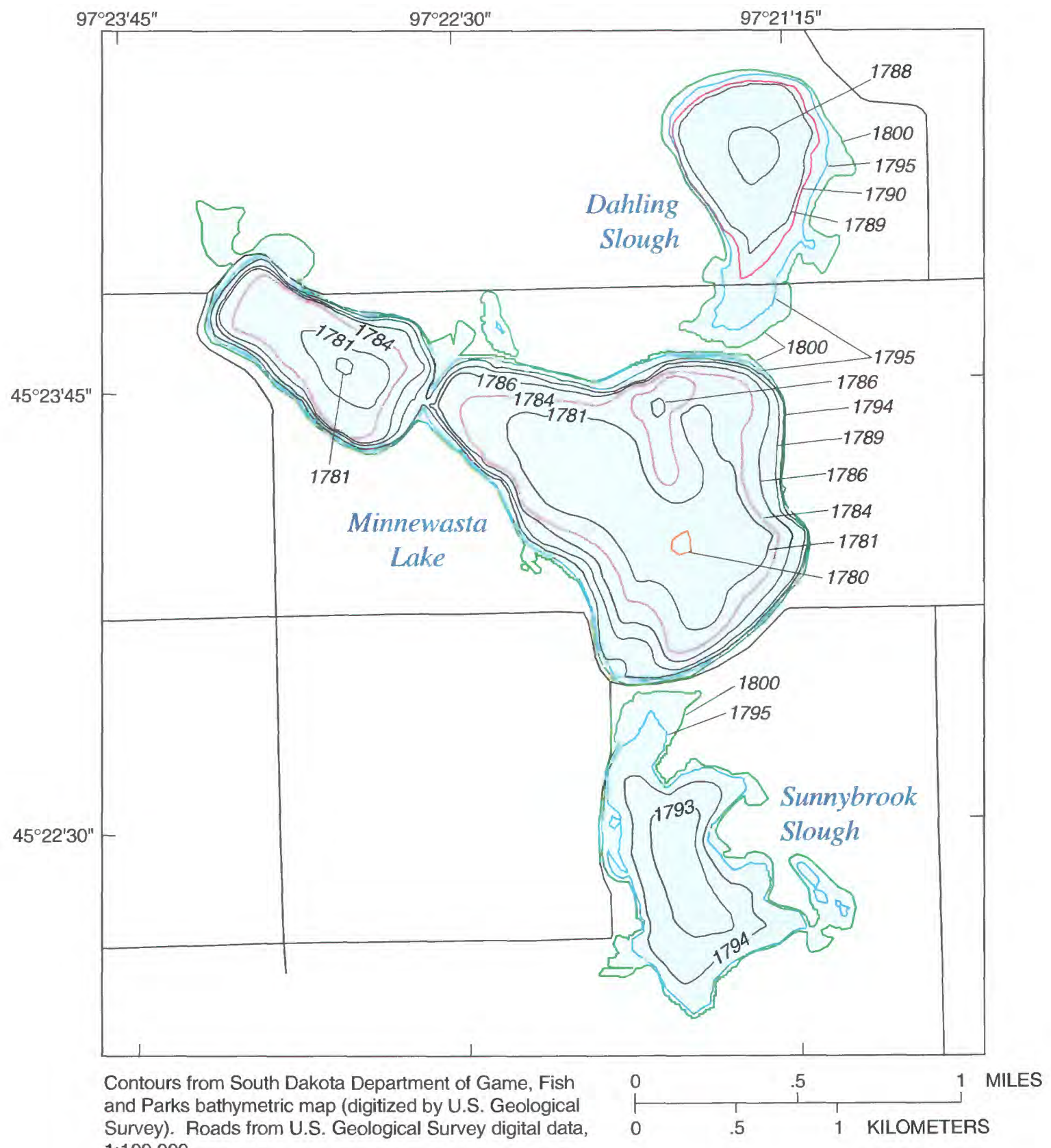

Survey). Roads from U.S. Geological Survey digital data, $1: 100,000$

\section{EXPLANATION}
- 1800 - BATHYMETRIC CONTOUR--Shows elevation of lake bottom, in feet above sea level. Contour intervals, varied. Colors used to differentiate contours

Figure D7. Bathymetric data for Minnewasta Lake. 


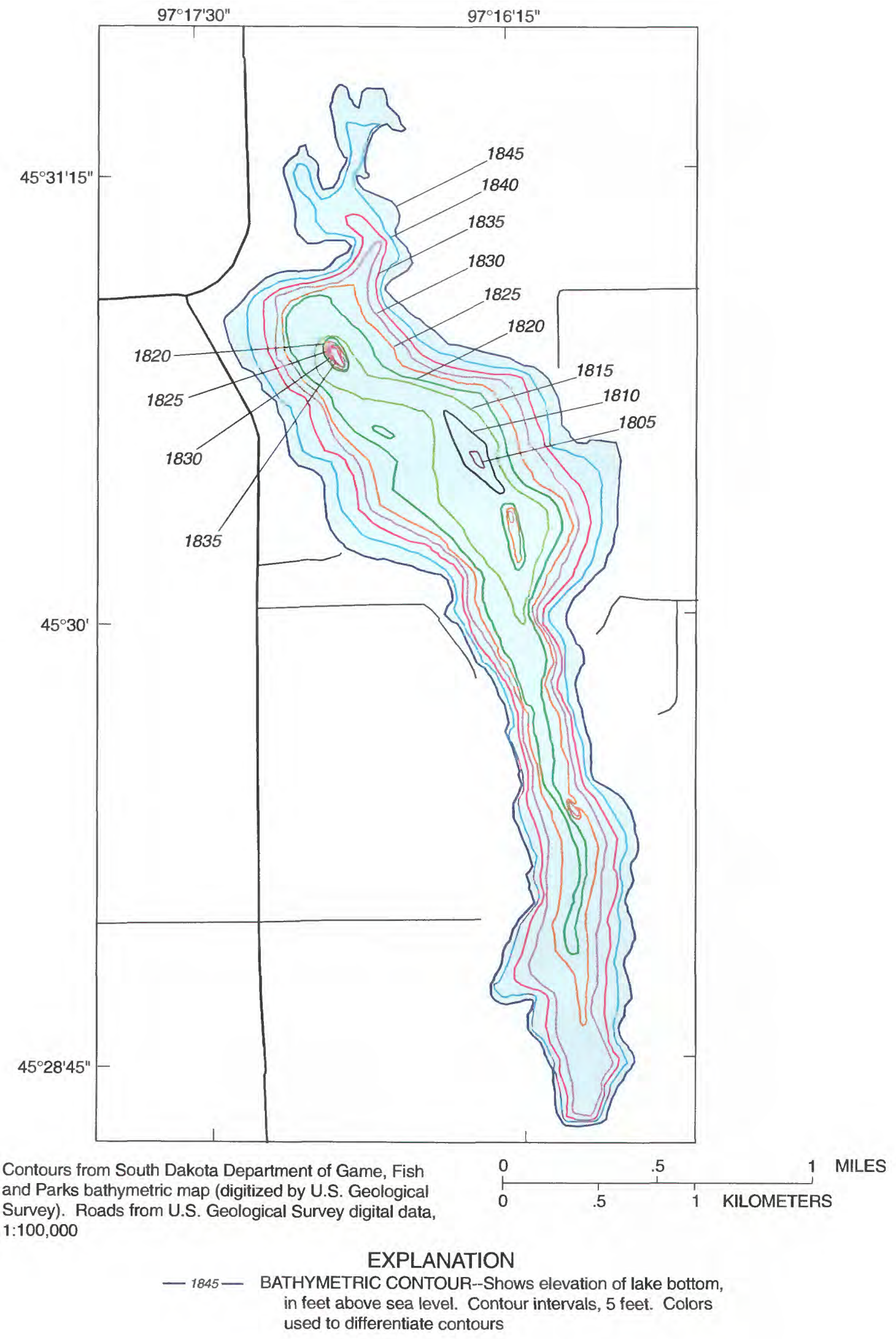

Figure D8. Bathymetric data for Pickerel Lake. 


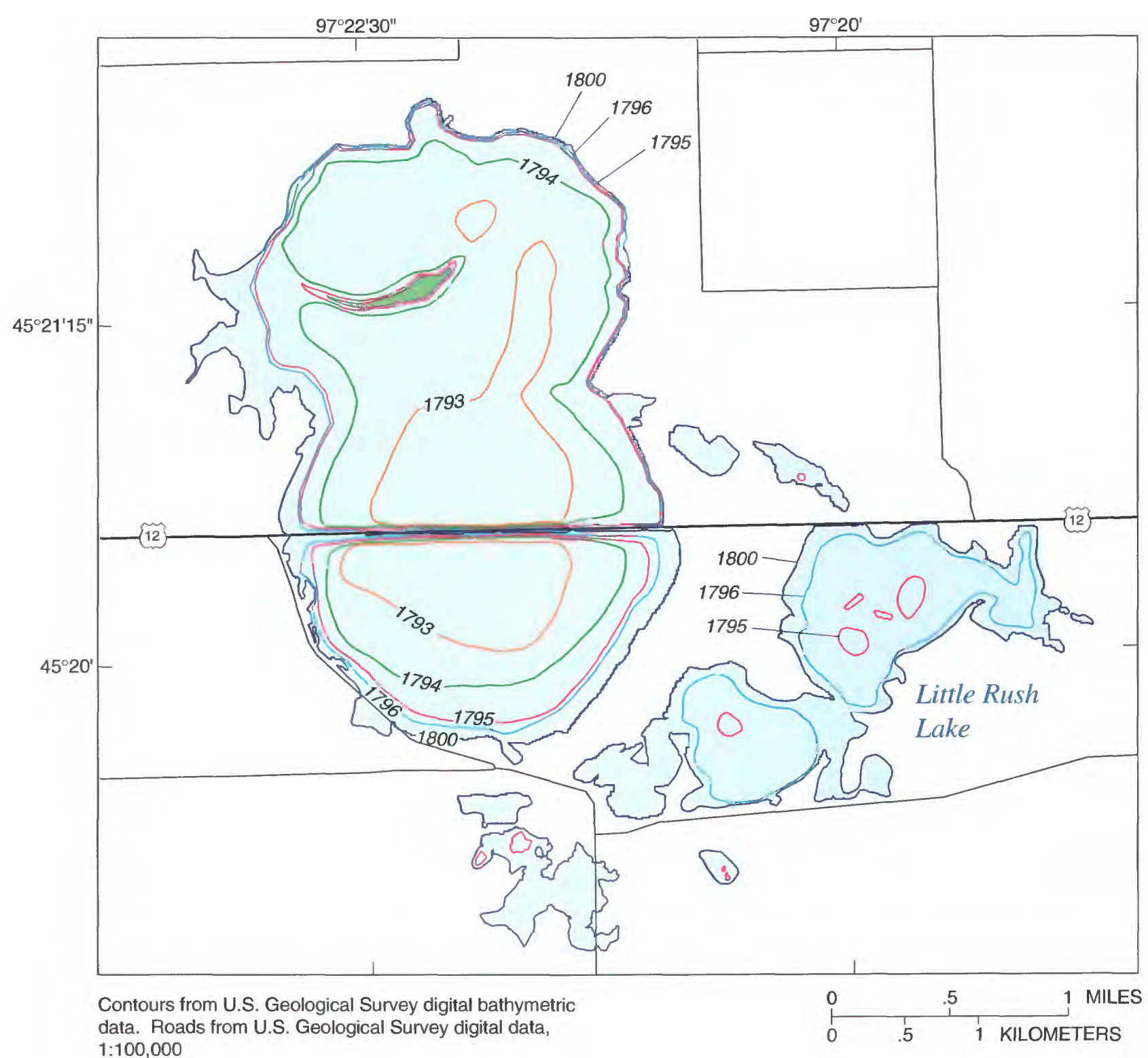

Roads from U.S. Geological Survey digital data $1: 100,000$

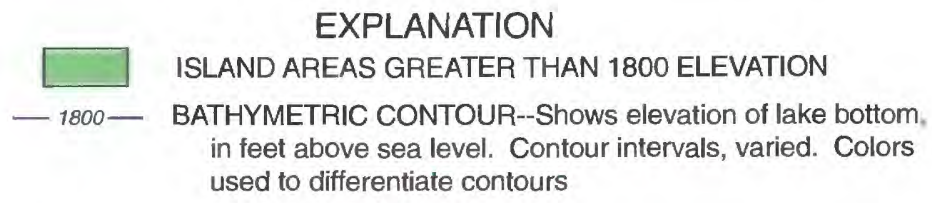

Figure D9. Bathymetric data for Rush Lake. 


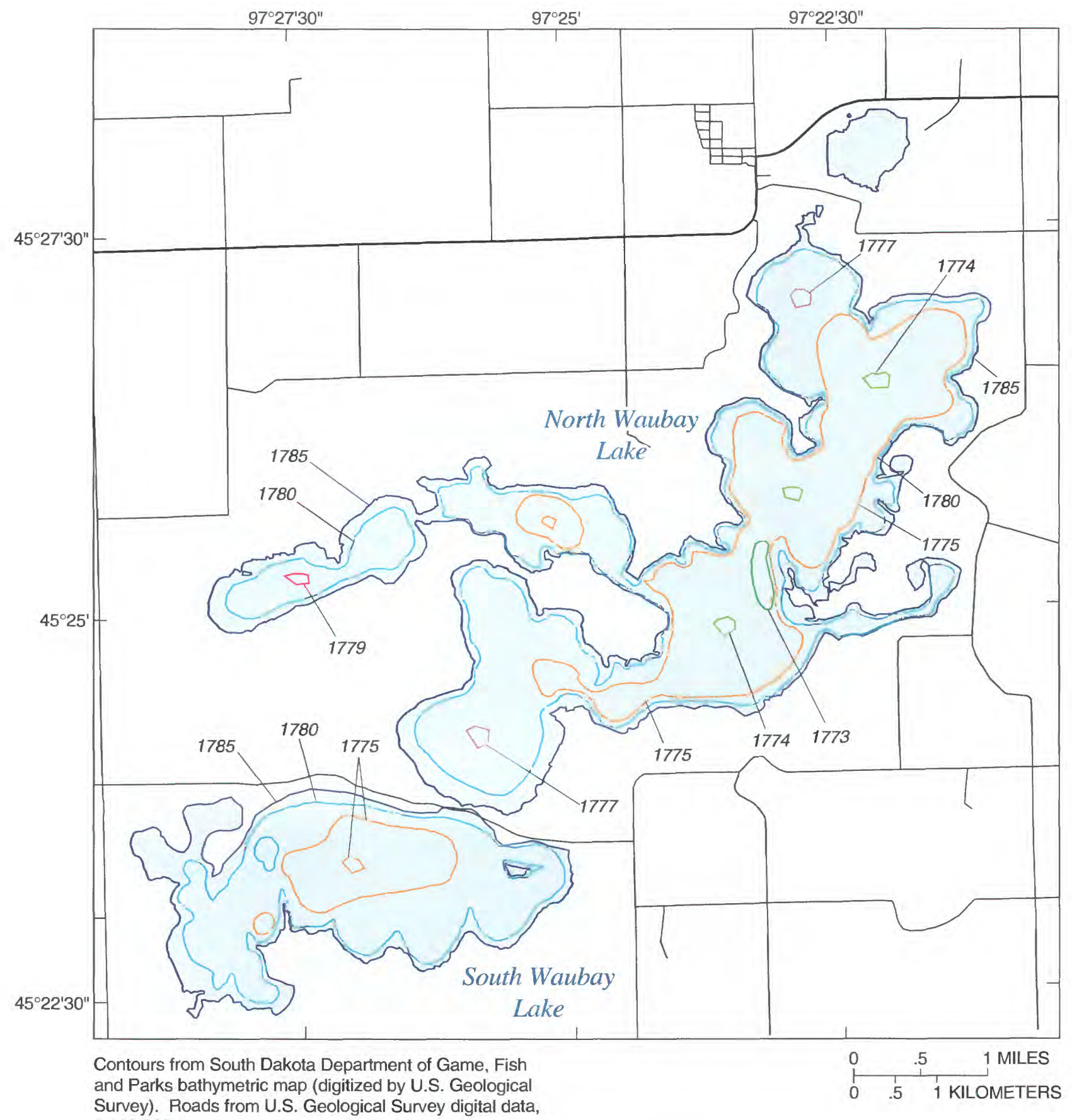

Survey). Roads from U.S. Geological Survey digital data, $1: 100,000$

\section{EXPLANATION}

- 1785 - BATHYMETRIC CONTOUR--Shows elevation of lake bottom, in feet above sea level. Contour intervals, varied. Colors used to differentiate contours

Figure D10. Bathymetric data for Waubay Lake. 


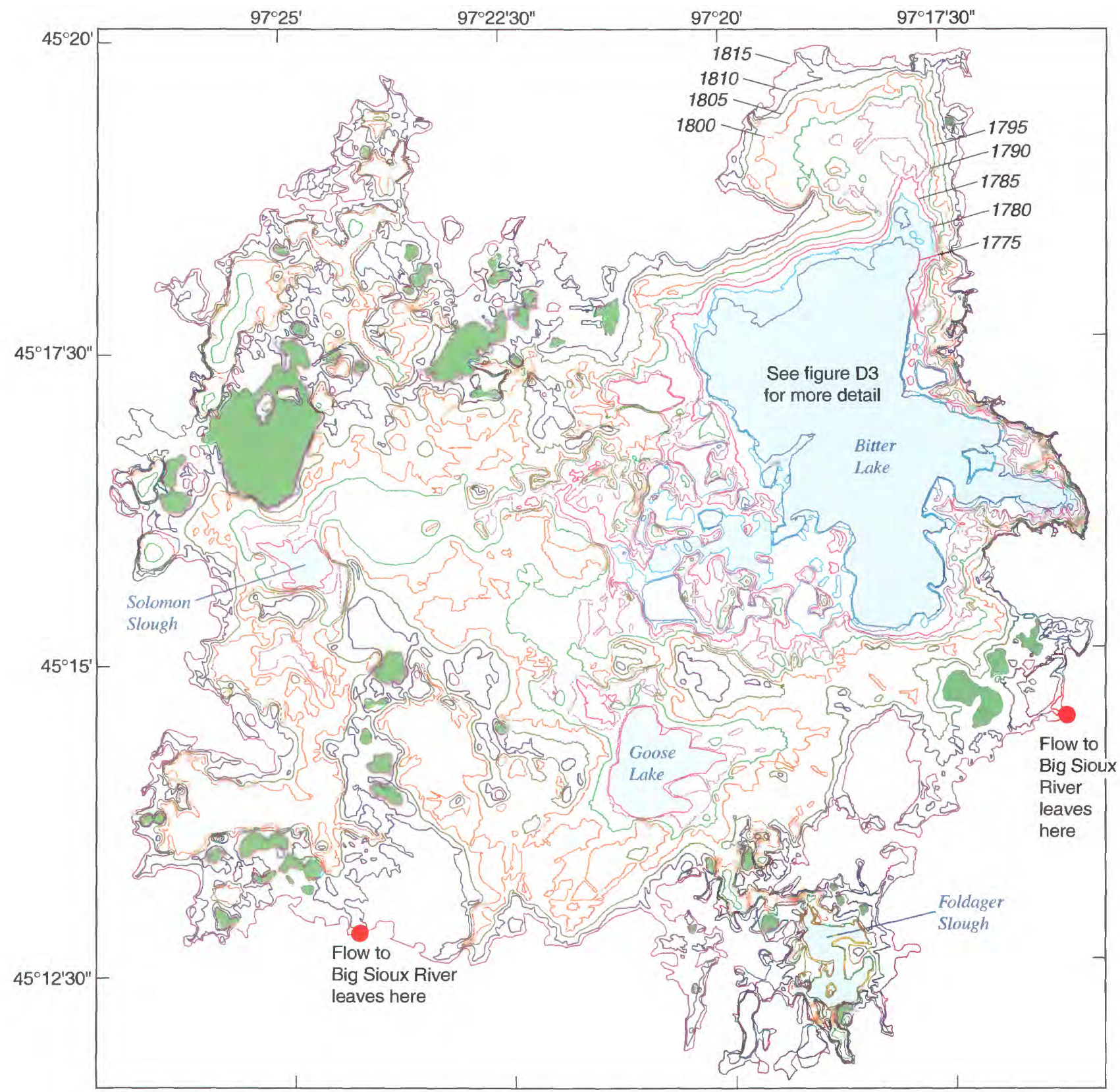

Contours from 10-meter digital elevation model data

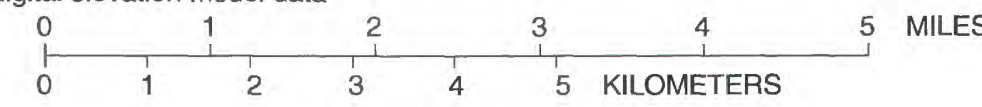

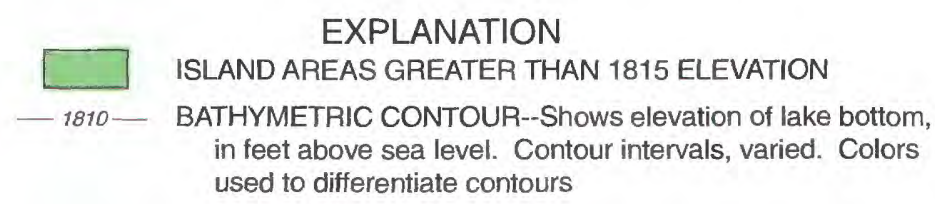

Figure D11. Additional bathymetric data for Bitter Lake. 


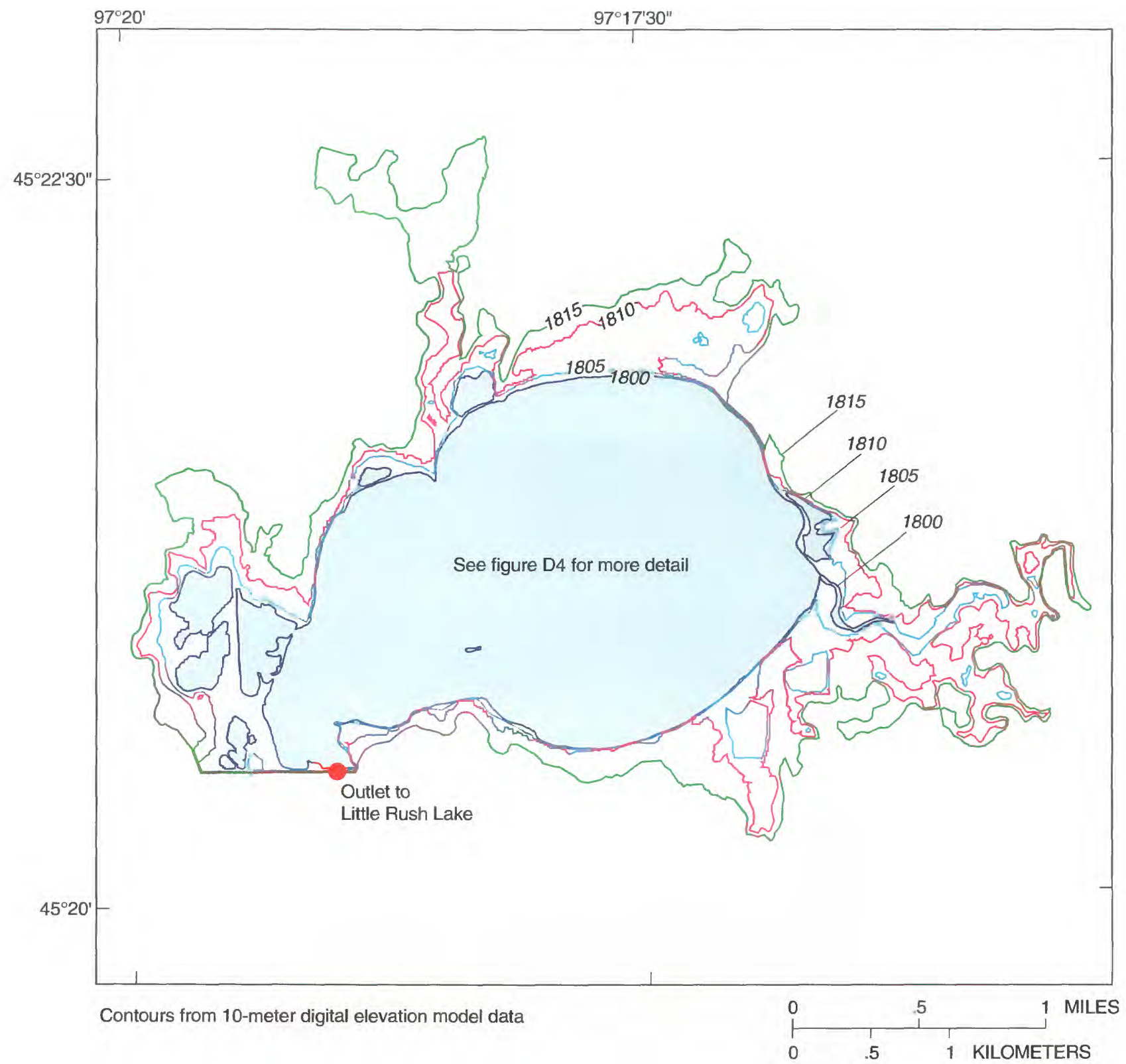

EXPLANATION

- 1800- BATHYMETRIC CONTOUR--Shows elevation of lake bottom, in feet above sea level. Contour intervals, 5 feet. Colors used to differentiate contours

Figure D12. Additional bathymetric data for Blue Dog Lake. 


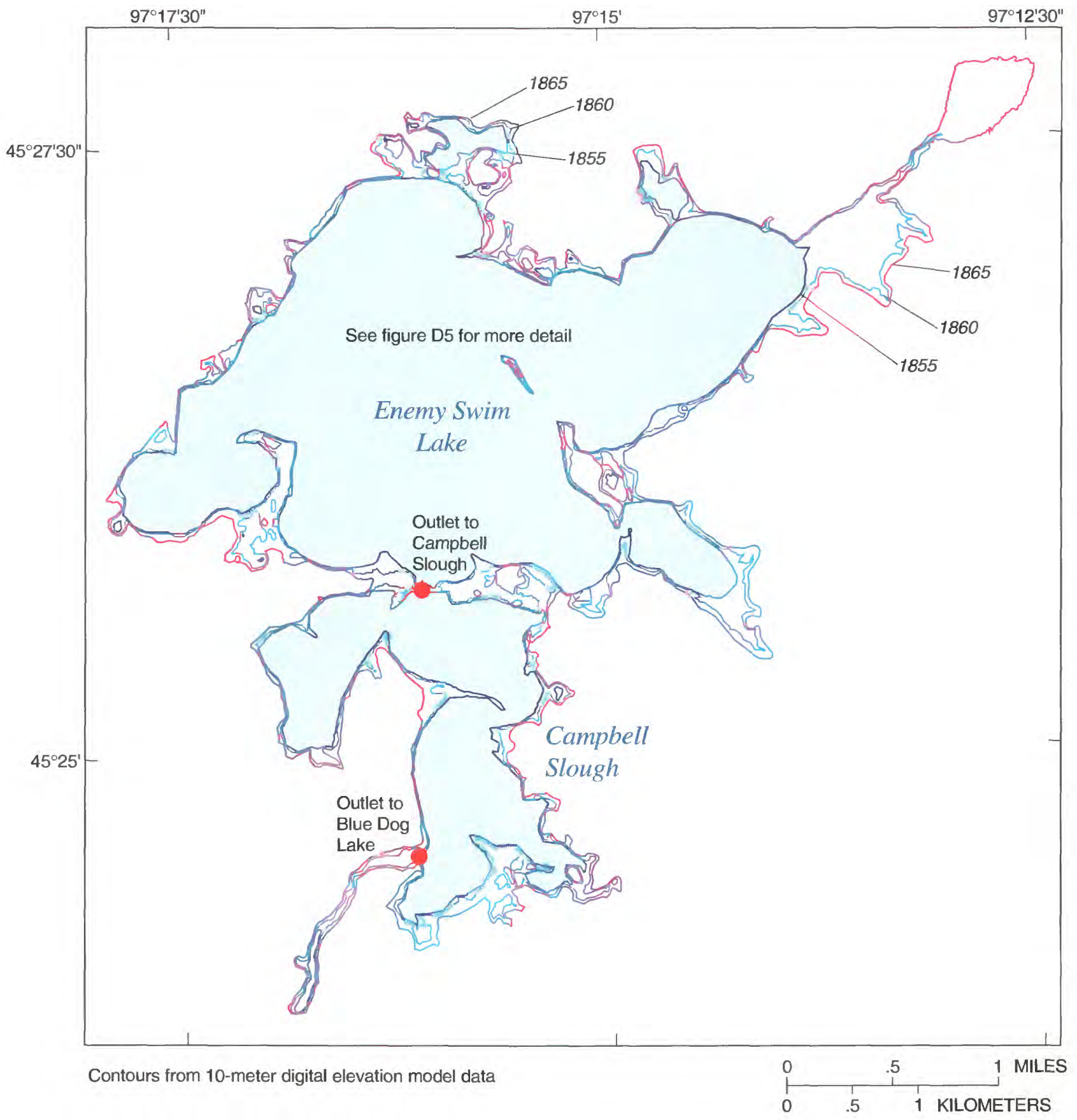

EXPLANATION

- 1855- BATHYMETRIC CONTOUR--Shows elevation of lake bottom, in feet above sea level. Contour intervals, varied. Colors used to differentiate contours

Figure D13. Additional bathymetric data for Enemy Swim Lake. 

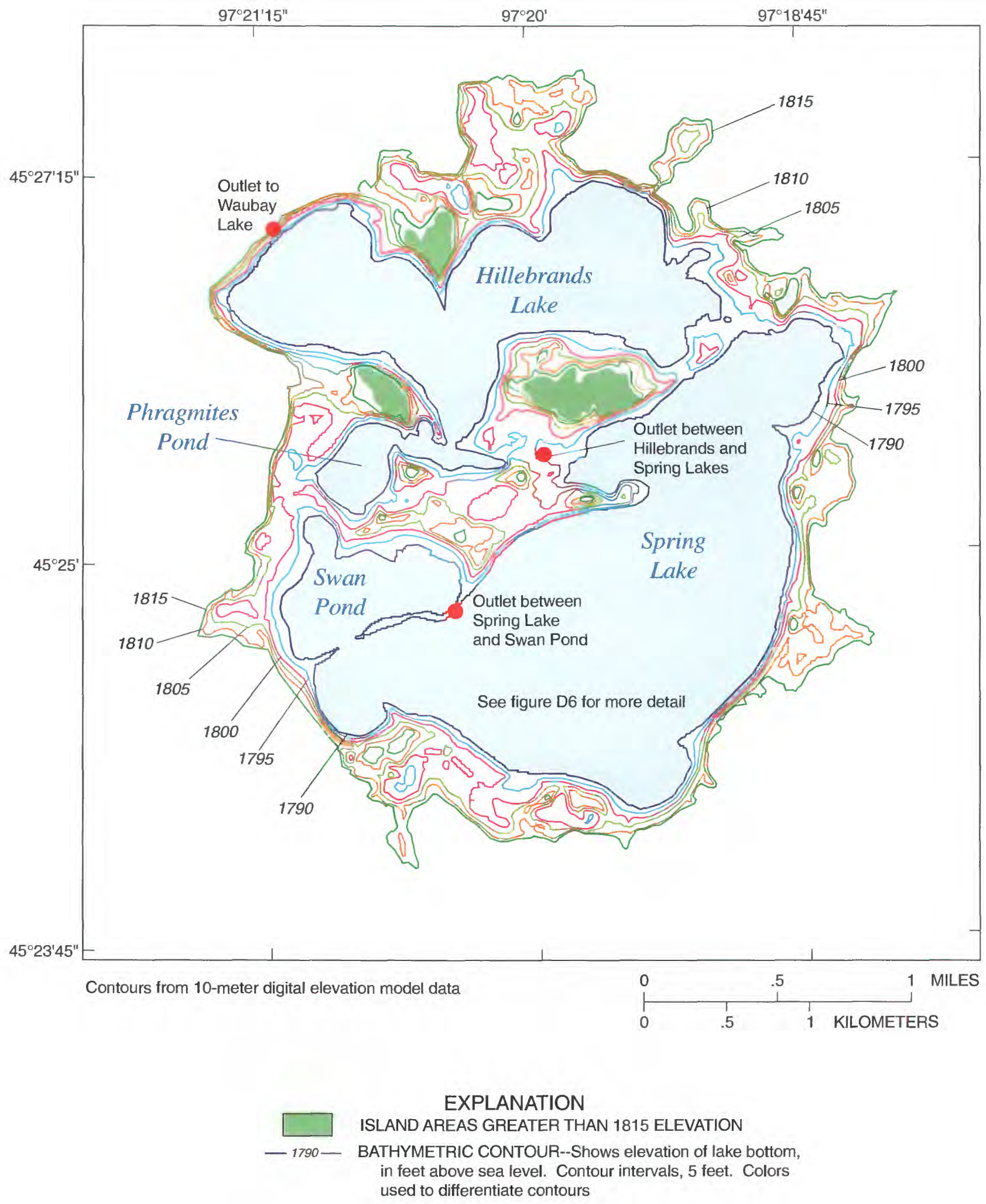

Figure D14. Additional bathymetric data for Hillebrands Lake, Spring Lake, and Swan Pond. 


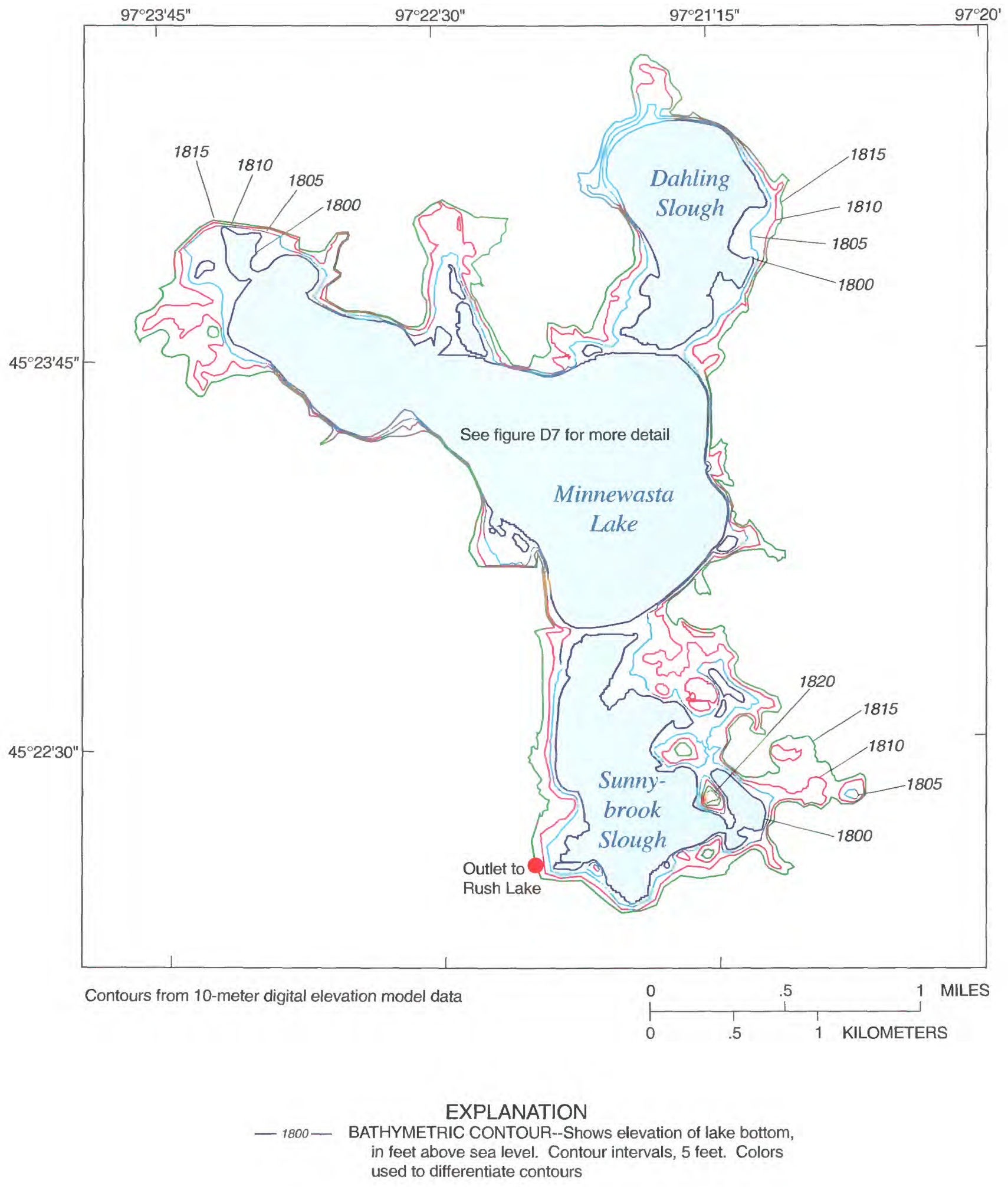

Figure D15. Additional bathymetric data for Minnewasta Lake. 


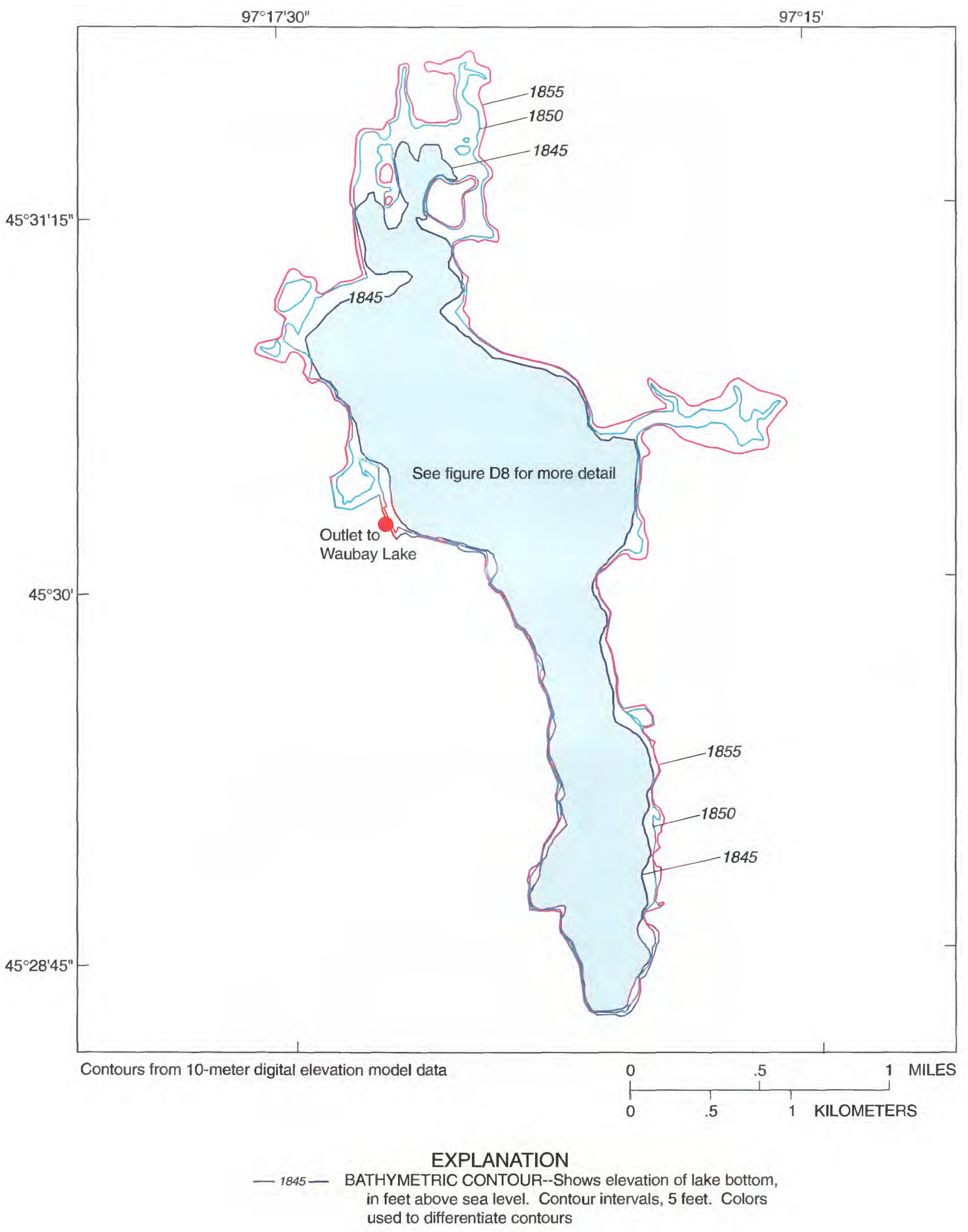

Figure D16. Additional bathymetric data for Pickerel Lake. 

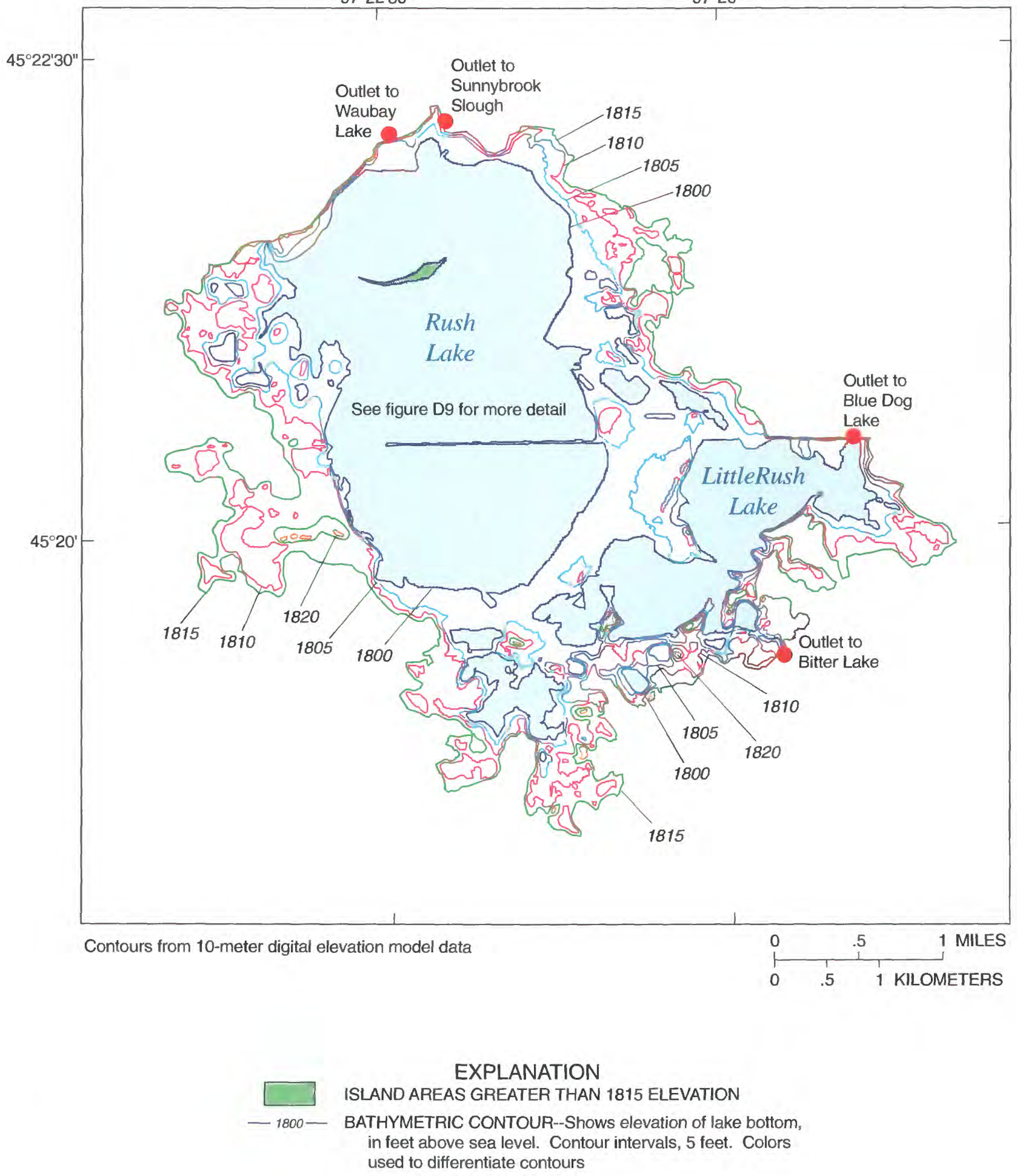

Figure D17. Additional bathymetric data for Rush Lake. 


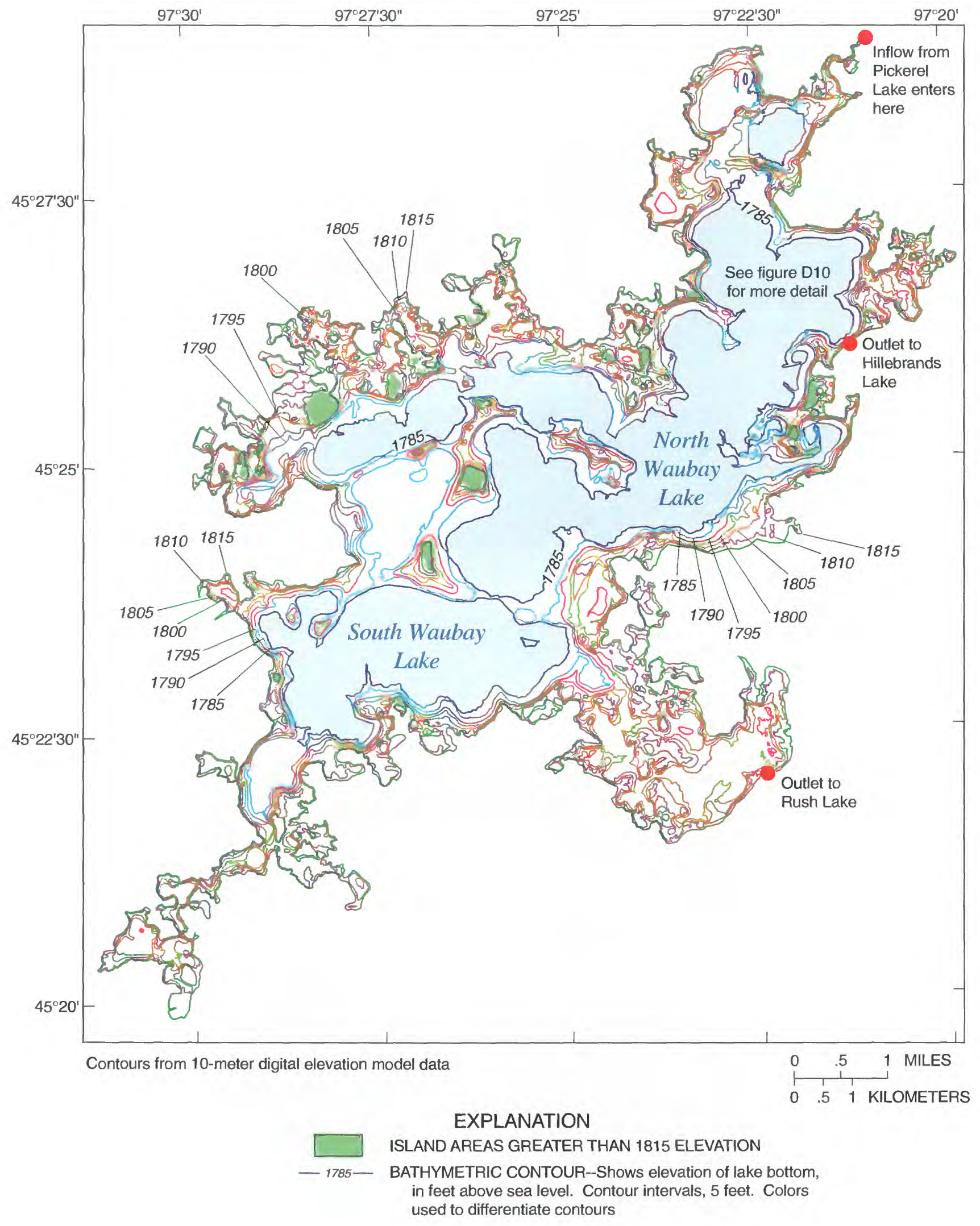

Figure D18. Additional bathymetric data for Waubay Lake. 